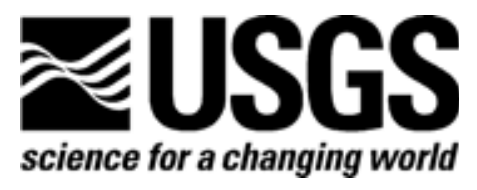

\title{
A NEW STREAMFLOW-ROUTING (SFR1) PACKAGE TO SIMULATE STREAM-AQUIFER INTERACTION WITH MODFLOW-2000
}

\section{U.S. GEOLOGICAL SURVEY}

OPEN-FILE REPORT 2004-1042

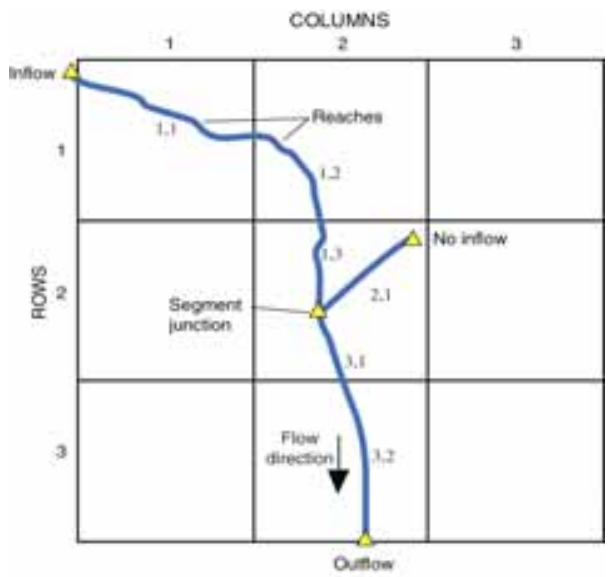

ExPLANATION

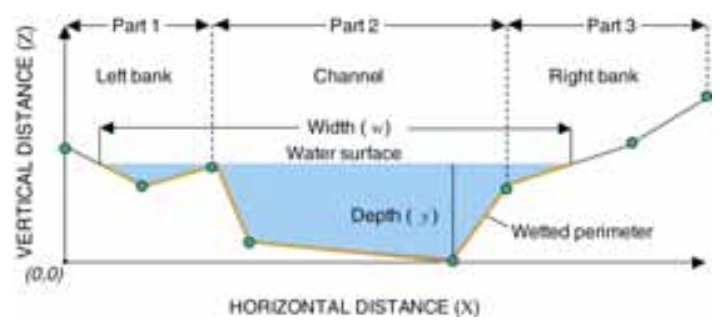

U.S. Department of the Interior

U.S. Geological Survey 
Cover: Map showing simple stream network and cross section through representative stream segment illustrating some of the nomenclature used in the Streamflow-Routing Package. (See figs. 1 and 4 of this report and related discussions for more details.) 
A NEW STREAMFLOW-ROUTING (SFR1) PACKAGE TO SIMULATE STREAM-AQUIFER INTERACTION WITH MODFLOW-2000

By David E. Prudic, Leonard F. Konikow, and Edward R. Banta

U.S. GEOLOGICAL SURVEY

OPEN-FILE REPORT 2004-1042 


\title{
U.S. DEPARTMENT OF THE INTERIOR \\ GALE A. NORTON, Secretary
}

\author{
U.S. GEOLOGICAL SURVEY \\ CHARLES G. GROAT, Director
}

Any use of trade, product, or firm names in this publication is for descriptive

purposes only and does not imply endorsement by the U.S. Government

For additional information

contact:

District Chief

U.S. Geological Survey

333 West Nye Lane, Room 203

Carson City, NV 89706-0866

email: GS-W-NVpublic-info @ usgs.gov

http://nevada.usgs.gov
Copies of this report can be purchased from:

U.S. Geological Survey

Information Services

Building 810

Box 25286, Federal Center

Denver, CO 80225-0286 


\section{CONTENTS}

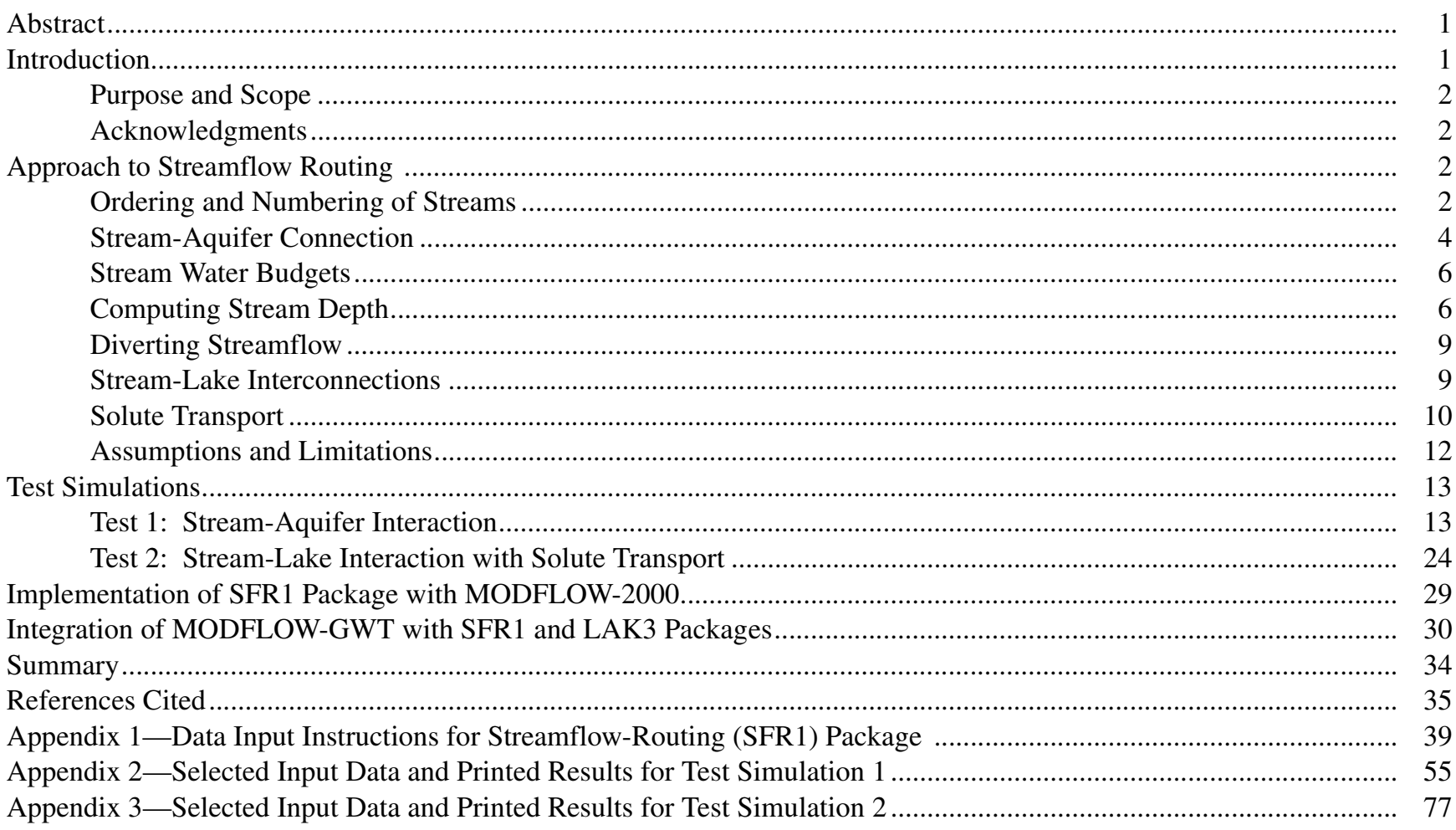

\section{FIGURES}

1. Diagram showing simple stream network having three segments and six reaches in a finite-difference model grid consisting of three rows and three columns.

2. Diagrams showing $(A)$ multiple connected reaches in a model cell, $(B)$ two parallel reaches in a model cell, and $(C)$ only one reach connected to a single model cell even if stream is wider than the cell.

3. Diagram showing example of a segment-numbering scheme in relation to direction of flow and a finite-difference model grid

4. Diagram illustrating an eight-point cross section used to compute depth, width, and wetted perimeter for a stream segment.

5. Diagram illustrating bisection-secant method used to determine depth of stream from Manning's equation assuming an eight-point cross section.

6. Map showing hypothetical basin-fill aquifer with model grid, land-surface contours, and stream segment and reach numbering scheme for test simulation 1

7. Model grid showing elevation of top of consolidated rocks beneath basin-fill aquifer and distribution of hydraulic conductivity and specific yield of the basin-fill aquifer used in test simulation 1 .

Model grid showing steady-state simulation of water-table contours, distribution of ground-water evapotranspiration, and locations of perennial-flow reaches used as initial conditions for the transient part of test simulation 1 .

9. Graphs showing stream cross sections used in computing stream depth for segments 7 and 8 in test simulation 1 
10. Model grid showing simulated water-table contours, distribution of ground-water evapotranspiration, and locations of perennial-flow reaches after 50 years of pumping for test simulation 1 .

11. Graphs comparing changes in stream depth, width, and flow in last reach of selected stream segments during a 50-year pumping period in test simulation 1 followed by a 50-year recovery period .....

12. Graphs showing changes in streambed conductance in last reach of selected stream segments during a 50-year pumping period in test simulation 1 followed by a 50-year recovery period.....

13. Diagram showing finite-difference model grid of layer 1, boundary conditions, and locations of lakes and streams used in test simulation 2 .

14. Diagrams showing contours of simulated steady-state heads in $(A)$ layer 1 and $(B)$ layer 2 for test simulation 2 .

15. Diagram showing distribution of vertical flow velocity between layers 1 and 2 for steady-state conditions in test simulation 2 .

16. Graphs showing changes in simulated boron concentrations in lake 1 and at the end of stream segments 2 , 3 , and 4 for steady ground-water flow and transient solute transport in test simulation 2 .....

17. Diagrams showing simulated boron concentrations in $(A)$ layer $1,(B)$ layer 3 , and $(C)$ layer 5 after 25 years of steady flow and transient solute transport in test simulation 2 .....

18. Generalized flow chart illustrating major components of the Streamflow-Routing (SFR1) Package in MODFLOW-2000.

19. Generalized flow chart illustrating major calculation steps in the integrated Streamflow-Routing (SFR1) and Lake (LAK3) Packages with MODFLOW-2000 and the Ground-Water Transport (GWT) Process, starting with solution of flow equation by a MODFLOW solver package

Tables

1. Inflow rates, streambed properties, stream characteristics, and methods used for calculating stream depth and width in test simulation 1

2. Relation of stream depth and width to streamflow used to compute stream depth and width for all reaches of stream segment 1 ( ICALC $=4)$ in test simulation 1

3. Computed ground-water budgets for test simulation 1

4. Hydraulic and transport properties used in test simulation 2 . 
CONVERSION FACTORS AND ABBREVIATIONS

\begin{tabular}{|c|c|c|}
\hline Multiply & By & To obtain \\
\hline \multicolumn{3}{|c|}{ Length } \\
\hline inch (in.) & 2.54 & centimeter $(\mathrm{cm})$ \\
\hline foot $(\mathrm{ft})$ & 0.3048 & meter $(\mathrm{m})$ \\
\hline \multicolumn{3}{|c|}{ Area } \\
\hline acre & 47 & square meter $\left(\mathrm{m}^{2}\right)$ \\
\hline square foot $\left(\mathrm{ft}^{2}\right)$ & 0.09290 & square meter $\left(\mathrm{m}^{2}\right)$ \\
\hline \multicolumn{3}{|c|}{ Volume } \\
\hline cubic foot $\left(\mathrm{ft}^{3}\right)$ & 0.02832 & cubic meter $\left(\mathrm{m}^{3}\right)$ \\
\hline \multicolumn{3}{|c|}{ Flow rate } \\
\hline $\begin{array}{l}\text { inch per year (in./yr) } \\
\text { foot per day }(\mathrm{ft} / \mathrm{d})\end{array}$ & $\begin{array}{l}2.54 \\
0.3048\end{array}$ & $\begin{array}{l}\text { centimeter per year }(\mathrm{cm} / \mathrm{yr}) \\
\text { meter per day }(\mathrm{m} / \mathrm{d})\end{array}$ \\
\hline cubic foot per second $\left(\mathrm{ft}^{3} / \mathrm{s}\right)$ & 0.02832 & cubic meter per second $\left(\mathrm{m}^{3} / \mathrm{s}\right)$ \\
\hline \multicolumn{3}{|c|}{ Hydraulic conductivity } \\
\hline foot per second $(\mathrm{ft} / \mathrm{s})$ & 0.3048 & meter per second $(\mathrm{m} / \mathrm{s})$ \\
\hline foot per day $(\mathrm{ft} / \mathrm{d})$ & 0.3048 & meter per day $(\mathrm{m} / \mathrm{d})$ \\
\hline \multicolumn{3}{|c|}{ Conductance } \\
\hline square foot per second $\left(\mathrm{ft}^{2} / \mathrm{s}\right)$ & 0.09290 & square meter per second $\left(\mathrm{m}^{2} / \mathrm{s}\right)$ \\
\hline \multicolumn{3}{|c|}{ Hydraulic gradient } \\
\hline foot per foot $(\mathrm{ft} / \mathrm{ft})$ & 1 & meter per meter $(\mathrm{m} / \mathrm{m})$ \\
\hline \multicolumn{3}{|c|}{ Leakance } \\
\hline foot per day per foot $[(\mathrm{ft} / \mathrm{d}) / \mathrm{ft}]$ & 1 & meter per day per meter $[(\mathrm{m} / \mathrm{d}) / \mathrm{m}]$ \\
\hline \multicolumn{3}{|c|}{ Storage coefficient and porosity } \\
\hline cubic foot per cubic foot $\left(\mathrm{ft}^{3} / \mathrm{ft}^{3}\right)$ & 1 & cubic meter per cubic meter $\left(\mathrm{m}^{3} / \mathrm{m}^{3}\right)$ \\
\hline \multicolumn{3}{|c|}{ Diffusion coefficient } \\
\hline square foot per day $\left(\mathrm{ft}^{2} / \mathrm{d}\right)$ & 0.09290 & square meter per day $\left(\mathrm{m}^{2} / \mathrm{d}\right)$ \\
\hline
\end{tabular}

Temperature in degrees Celsius $\left({ }^{\circ} \mathrm{C}\right)$ may be converted to degrees Fahrenheit $\left({ }^{\circ} \mathrm{F}\right)$ as follows:

${ }^{\circ} \mathrm{F}=\left(1.8 \times{ }^{\circ} \mathrm{C}\right)+32$

Temperature in degrees Fahrenheit $\left({ }^{\circ} \mathrm{F}\right)$ may be converted to degrees Celsius $\left({ }^{\circ} \mathrm{C}\right)$ as follows:

${ }^{\circ} \mathrm{C}=\left({ }^{\circ} \mathrm{F}-32\right) / 1.8$

Vertical coordinate information is referenced to the North American Vertical Datum of 1988 (NAVD 88).

Horizontal coordinate information is referenced to the North American Datum of 1988 (NAVD 88).

Elevation, as used in this report, refers to distance above the vertical datum.

Concentrations of chemical constituents in water are given either in milligrams per liter $(\mathrm{mg} / \mathrm{L})$ or micrograms per liter $(\mu \mathrm{g} / \mathrm{L})$. 


\section{PREFACE}

A new Streamflow-Routing (SFR1) Package was written for use with the U.S. Geological Survey (USGS) MODFLOW-2000 ground-water model and the Ground-Water Transport (GWT) Process in MODFLOW (MODFLOW-GWT). The package replaces an older Stream (STR1) Package that was written for earlier versions of MODFLOW. The SFR1 Package is designed to simulate stream-aquifer interactions and to route flow and a single solute through a network of surface-water channels. The new version offers improved efficiency in the input of data and offers more options in computing stream depth and width.

The performance of this computer program has been tested in models of hypothetical ground-water flow systems; however, future applications of the programs may reveal errors that were not detected in the test simulations. Users are requested to notify the USGS if errors are found in the documentation report or in the computer program. Correspondence regarding the report or program should be sent to:

\section{U.S. Geological Survey, WRD \\ 333 West Nye Lane, Room 203 \\ Carson City, Nevada 89706 \\ Attention: David E. Prudic}

Although the computer program has been used by the USGS, no warranty, expressed or implied, is made by the USGS or the United States Government as to the accuracy and functionality of the program and related program material. Nor shall the fact of distribution constitute any such warranty, and no responsibility is assumed by the USGS in connection therewith.

MODFLOW-2000, the SFR1 Package, MODFLOW-GWT, and other ground-water programs are available from the USGS at the following World Wide Web (WWW) addresses:

http://water.usgs.gov/software/ http://water.usgs.gov/nrp/gwsoftware/

or by anonymous ftp file transfer from directory/pub/software/ground_water/modflow

at Internet address: water.usgs.gov 


\title{
A New Streamflow-Routing (SFR1) Package to Simulate Stream-Aquifer Interaction with MODFLOW-2000
}

\author{
By David E. Prudic, Leonard F. Konikow, and Edward R. Banta
}

\section{Abstract}

The increasing concern for water and its quality require improved methods to evaluate the interaction between streams and aquifers and the strong influence that streams can have on the flow and transport of contaminants through many aquifers. For this reason, a new Streamflow-Routing (SFR1) Package was written for use with the U.S. Geological Survey's MODFLOW-2000 ground-water flow model. The SFR1 Package is linked to the Lake (LAK3) Package, and both have been integrated with the Ground-Water Transport (GWT) Process of MODFLOW-2000 (MODFLOW-GWT). SFR1 replaces the previous Stream (STR1) Package, with the most important difference being that stream depth is computed at the midpoint of each reach instead of at the beginning of each reach, as was done in the original Stream Package. This approach allows for the addition and subtraction of water from runoff, precipitation, and evapotranspiration within each reach. Because the SFR1 Package computes stream depth differently than that for the original package, a different name was used to distinguish it from the original Stream (STR1) Package.

The SFR1 Package has five options for simulating stream depth and four options for computing diversions from a stream. The options for computing stream depth are: a specified value; Manning's equation (using a wide rectangular channel or an eight-point cross section); a power equation; or a table of values that relate flow to depth and width. Each stream segment can have a different option. Outflow from lakes can be computed using the same options. Because the wetted perimeter is computed for the eight-point cross section and width is computed for the power equation and table of values, the streambed conductance term no longer needs to be calculated externally whenever the area of streambed changes as a function of flow. The concentration of solute is computed in a stream network when MODFLOW-GWT is used in conjunction with the SFR1 Package. The concentration of a solute in a stream reach is based on a mass-balance approach and accounts for exchanges with (inputs from or losses to) ground-water systems.

Two test examples are used to illustrate some of the capabilities of the SFR1 Package. The first test simulation was designed to illustrate how pumping of ground water from an aquifer connected to streams can affect streamflow, depth, width, and streambed conductance using the different options. The second test simulation was designed to illustrate solute transport through interconnected lakes, streams, and aquifers. Because of the need to examine time series results from the model simulations, the Gage Package first described in the LAK3 documentation was revised to include time series results of selected variables (streamflows, stream depth and width, streambed conductance, solute concentrations, and solute loads) for specified stream reaches.

The mass-balance or continuity approach for routing flow and solutes through a stream network may not be applicable for all interactions between streams and aquifers. The SFR1 Package is best suited for modeling long-term changes (months to hundreds of years) in ground-water flow and solute concentrations using averaged flows in streams. The Package is not recommended for modeling the transient exchange of water between streams and aquifers when the objective is to examine short-term (minutes to days) effects caused by rapidly changing streamflows.

\section{Introduction}

Flow and transport of contaminants through many surficial aquifers can be strongly affected by interaction with surface water. Computer programs that simulate the processes of ground-water flow and contaminant transport through aquifers are widely used to evaluate and manage ground-water resources. Because of increased awareness of the interaction between streams and aquifers, a new Streamflow-Routing (SFR1) Package was written for use with the U.S. Geological Survey's MODFLOW-2000 ground-water flow model (Harbaugh and others, 2000) and the Ground-Water Transport (GWT) Process in MODFLOW (MODFLOW-GWT; Konikow and others, 1996). The SFR1 Package replaces an older Stream (STR1) Package (Prudic, 1989) written for earlier versions of MODFLOW (McDonald and Harbaugh, 1984; 1988; and Harbaugh and McDonald, 1996a; 1996b). Similar to the STR1 Package, the SFR1 Package is written in FORTRAN-77; has been developed in a modular style; and uses the continuity equation to route surface-water flow through one or more simulated rivers, streams, canals, or ditches, which may or may not be interconnected.

Although revisions to MODFLOW normally allow input data used by earlier versions to be read without change, the SFR1 Package is sufficiently different from STR1 that input 
data from STR1 cannot be read directly into SFR1. Additionally, the SFR1 Package calculates flow across the streambed on the basis of stream depth calculated at the midpoint of a reach, whereas STR1 calculates flow across the streambed on the basis of stream depth calculated at the beginning of a reach. Thus, the simulated exchange across the streambed using the same data in both packages will likely differ between the SFR1 Package and the STR1 Package. For these reasons, the SFR1 Package has a different name to distinguish it from the previous version.

\section{Purpose and Scope}

The purposes for developing the SFR1 Package were: (1) to reduce repetition of non-changing values required for each stress period in the STR1 Package (for example; if flow changed for one stream at the beginning of a new stress period, all cell locations for all streams and their connections had to be repeated); (2) to allow more options in calculating stream depth as a function of streamflow; (3) to allow options for calculating streambed conductance as a function of wetted perimeter or stream width; (4) to allow options for including precipitation, overland flow, and evapotranspiration along a stream segment; (5) to allow more options for diverting flow from a stream; and (6) to simulate solute transport within a stream network and between streams and aquifers.

This report explains the basic design and concepts of the SFR1 Package, including several new options. The report also describes the connection between the SFR1 Package and the Lake (LAK3) Package (Merritt and Konikow, 2000), and with MODFLOW-GWT (an upgrade to the MOC3D model documented by Konikow and others, 1996). Test simulations are used to illustrate the capabilities of the package. Data input instructions are provided that are needed to use the program.

\section{Acknowledgments}

The USGS Ground-Water Resources Program and the Southwest Ground-Water Resources Project funded this work. Several people provided useful suggestions on the design and structure of the SFR1 Package including: Jon Fenske and Paul Ely of the U.S. Army Corps of Engineers, Hydrologic Engineering Center, Davis, California; and Randall Hanson, Arlen W. Harbaugh, George Z. Hornberger, Randall Hunt, Stanley Leake, and Michael Merritt (retired) of the U.S. Geological Survey.

\section{Approach to Streamflow Routing}

Streamflow routing within the SFR1 Package is based on the continuity equation and assumption of piecewise steady (nonchanging in discrete time periods), uniform (nonchanging in location), and constant-density streamflow, such that during all times, volumetric inflow and outflow rates are equal and no water is added to or removed from storage in the surface channels. This is the same approach that was used in the previous STR1 Package (Prudic, 1989).
The program is designed to route streamflow through a network of channels (which may include rivers, streams, canals, and ditches and are referred to collectively as streams in the remainder of the report). Streamflow is always in the same direction along the channels, and is constant for each time step used in the ground-water flow model. If changes in streamchannel storage during each time step used in the ground-water flow model are important, then more complicated, one-dimensional unsteady flow models may be required; such models have been linked to MODFLOW and are available to simulate stream-aquifer interactions (MODBRANCH by Swain and Wexler, 1996; and DAFLOW by Jobson and Harbaugh, 1999).

\section{Ordering and Numbering of Streams}

The network of streams defined in the SFR1 Package is divided into reaches and segments. A stream reach is a section of a stream that is associated with a particular finite-difference cell used to model ground-water flow and transport. A segment is a group of reaches that have (1) uniform rates of overland flow and precipitation to them; (2) uniform rates of evapotranspiration from them; (3) uniform or linearly changing properties (for example; streambed elevation, thickness, and hydraulic conductivity, and stream depth and width); (4) tributary flows or specified inflow or outflow (only in the first reach); and (5) diversions (only from the last reach).

A simple example of a stream network superimposed on a finite-difference grid of an aquifer that has three columns and three rows is shown in figure 1. Each finite-difference cell is designated first by row number followed by column number [for example; cell $(1,2)$ is row 1, column 2]. In this example, the first stream segment has three reaches and inflow into this segment is specified. The first reach is in cell $(1,1)$; the second reach is in cell $(1,2)$; and the third reach is in cell $(2,2)$. The second stream segment has only one reach in cell $(2,2)$. Inflow into this segment can be specified as zero such that flow into the stream occurs only when the head in the aquifer exceeds the elevation of the streambed. The third segment also has two reaches; however, inflow is based on the combined outflow from segments 1 and 2 (called segment junction in fig. 1). The first reach of segment three is in cell $(2,2)$; and the second reach is in cell $(3,2)$.

More than one stream reach can be assigned to a model cell (figs. 1 and 2). Stream reaches may join together (fig. $2 A$ ) or parallel reaches can flow across a cell without joining (fig. $2 B$ ). When there is more than one stream reach in a model cell, the simulated ground-water head in the cell is used to calculate ground-water exchange for each of the stream reaches associated with the cell; and the SFR1 Package (like STR1) maintains the accounting for all stream reaches contained in the cell. However, neither the SFR1 Package nor the STR1 Package allow for one stream reach to be associated with more than one model cell (fig. $2 C$ ). 
COLUMNS

1

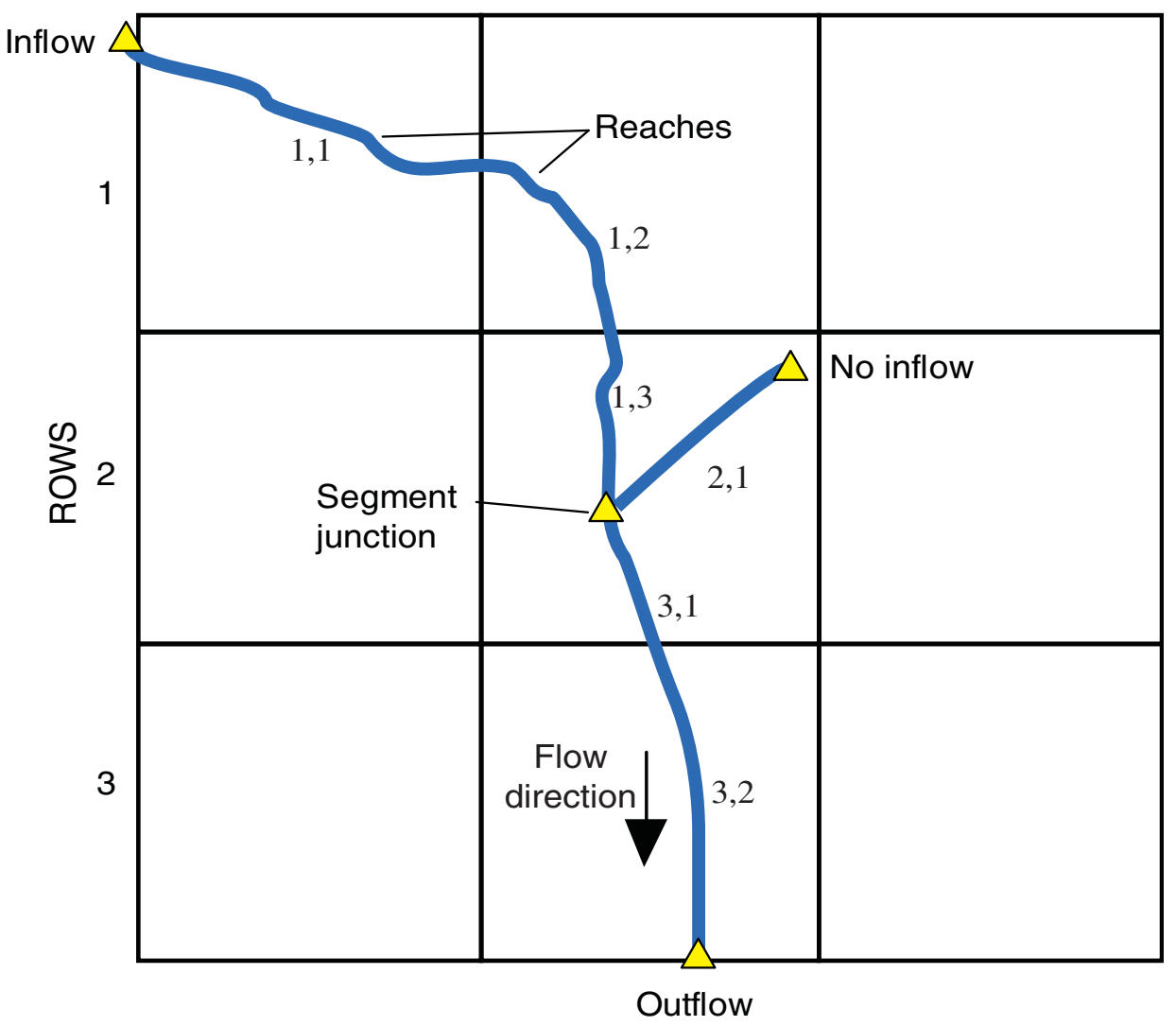

EXPLANATION

\section{1,3 Segment number and reach number Stream}

Figure 1. Simple stream network having three segments and six reaches in a finitedifference model grid consisting of three rows and three columns.

The numbering of segments and reaches is important. Segments are numbered sequentially from the farthest upstream segment to the last downstream segment. Multiple segments may be joined as tributary streams. In most instances, the joining segments will not be sequential. However, as long as the upstream segments have a lower number than the downstream segment, outflows from the upstream segments will be added correctly as inflow to the downstream segment. If tributary segments have higher numbers than the connecting downstream segments, then outflows from the higher numbered tributary segments will be from the previous iteration during the MODFLOW solution of ground-water heads for each time step. As long as the difference in head between iterations is small (a small specified closure criteria), the error caused by adding outflow from the previous iteration in the higher numbered tributary segments to the lower numbered connecting segments will be small. Reaches within a segment must be numbered sequentially from the farthest upstream reach in a segment to the last downstream reach, such as is illustrated in figure 1. The program will not correctly add and subtract flows between reaches if they are not in sequential order. An example of a finite-difference grid of a hypothetical aquifer connected to streams is shown in figure 3.

For each segment and reach, the basic information of the layer, row, and column of the cell that corresponds to each reach and the length of the stream reach in the cell is read only once for a model simulation. This differs from STR1, where the basic information could be read for each new stress (time) period. The new method of data input reduces repetition, but assumes that the locations of rivers, streams, canals, and ditches remain fixed during the simulation. However, not all specified segments need be simulated during a stress period. 
A. Connected reaches in a model cell

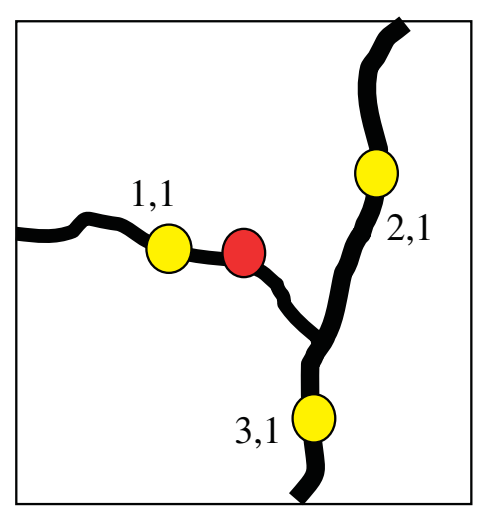

B. Parallel reaches in a model cell

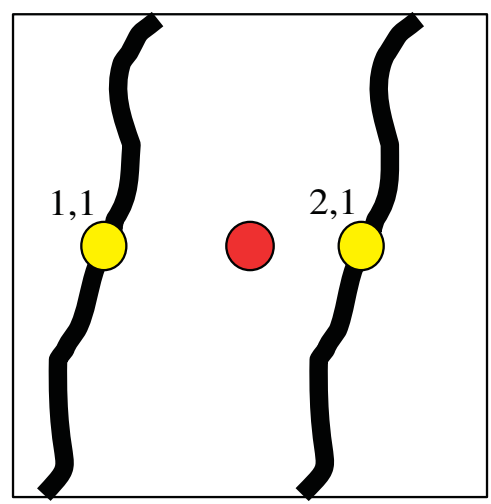

C. One reach per model cell

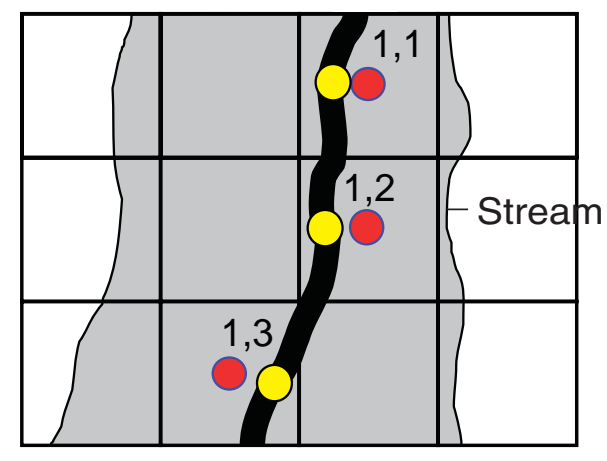

\section{EXPLANATION}

\section{Cell node in finite-difference grid}

\section{Midpoint of stream reach in model cell}

\section{1,1 Segment number and reach number}

Figure 2. Diagrams showing $(A)$ multiple connected reaches in a model cell, $(B)$ two parallel reaches in a model cell, and $(C)$ only one reach connected to a single model cell even if stream is wider than the cell.

\section{Stream-Aquifer Connection}

Conceptually, the method of computing flow between streams and aquifers is the same as that used for the standard River Package (RIV; McDonald and Harbaugh, 1988, chapter 6) and for the previous Stream Package (STR1; Prudic, 1989, p. 6-8). Flow between streams and aquifers in the ground-water model is computed using Darcy's Law and assuming uniform flow between a stream and aquifer over a given section of stream and corresponding volume of aquifer. This flow is computed as:

$$
Q_{L}=\frac{K w L}{m}\left(h_{s}-h_{a}\right),
$$

where

$Q_{L}$ is a volumetric flow between a given section of stream and volume of aquifer, in units of volume per time;

$K$ is the hydraulic conductivity of streambed sediments, in units of length per time;

$w$ is a representative width of stream, in units of length; 
$L$ is the length of stream corresponding to a volume of aquifer, in units of length;

$m$ is the thickness of the streambed deposits extending from the top to the bottom of the streambed, in units of length;

$h_{s}$ is the head in the stream determined by adding stream depth to the elevation of the streambed, in units of length; and

$h_{a}$ is the head in the aquifer beneath the streambed, in units of length.

In this formulation, transient leakage across the streambed could change depending on both the stream head and the aquifer head calculated during the time step. The RIV and STR1 Packages require that a conductance term $(K w L / m)$ be specified for the streambed. In the SFR1 Package, the conductance term is calculated from hydraulic conductivity, stream length, and streambed thickness, which is read in the data input, and stream width, which is either read in the data input or computed on the basis of streamflow. This creates greater flexibility for the user, allows for conductance to vary as a function of stream wetted width, and eliminates the need to externally estimate the conductance term.
When the head in the aquifer is below the streambed bottom elevation, leakage from the stream to the underlying aquifer is no longer dependent on aquifer head; in this case, flow across the streambed is estimated by computing the head gradient across the streambed assuming that the head at the bottom of the streambed is equal to the streambed bottom elevation. Implied in this method of calculating leakage to the aquifer is that the interval between the bottom of the streambed and the water table has a unit downward gradient, that flow across the streambed is translated directly to the water table without delay, and that the leakage rate does not exceed the saturated hydraulic conductivity of the deposits or rocks that occupy the interval between the streambed and water table. Such assumptions generally are reasonable when the unsaturated interval is thin or when long periods of steady (constant) flow are modeled, and the hydraulic gradient across the streambed does not greatly exceed one. In transient simulations, the leakage rate across the streambed can change depending on the head of the stream. The hydraulic gradient across the streambed is reported for each reach and it is left to the user to decide if the gradients are reasonable. Gradients that greatly exceed one may result in unreasonably large leakage rates. If the leakage rates are unreasonable, streambed and aquifer properties used for that reach in the model might need to be examined and possibly field-checked.

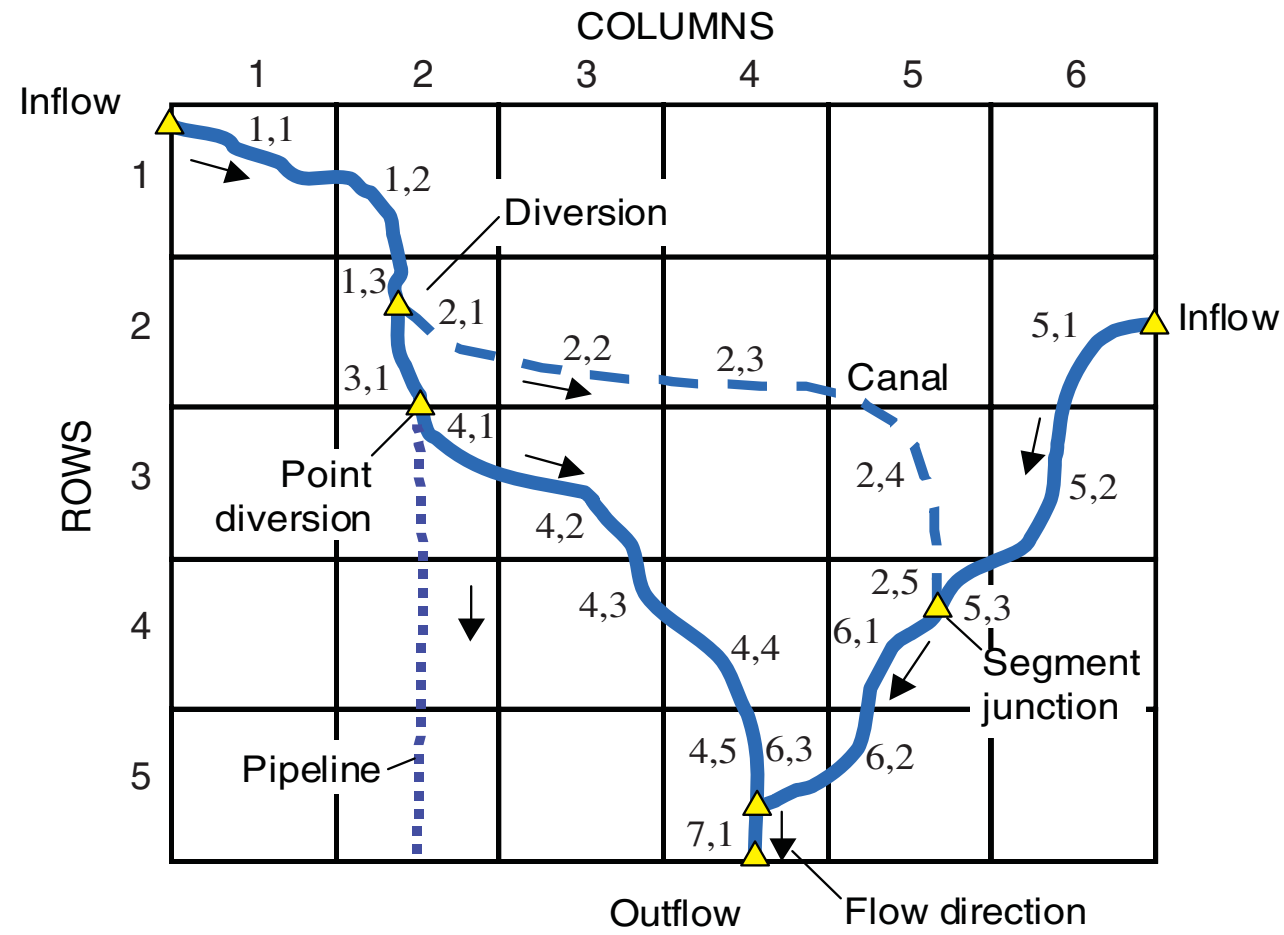

EXPLANATION

\section{1,1 Segment number and reach number Stream}

Figure 3. Example of a segment-numbering scheme in relation to direction of flow and a finitedifference model grid. 


\section{A new Streamflow-Routing (SFR1) Package}

The layer, row, and column of each stream reach are specified in the model input (Appendix 1). If the cell corresponding to the stream reach is inactive, the program will search for the uppermost active cell having the same row and column identifier. If all cells beneath the stream reach are inactive or if the cell corresponding to the stream reach is set as a constant head, the program will continue to route flow through the stream reach, but leakage (either into the aquifer or out of the aquifer) across the streambed will not occur in the reach.

\section{Stream Water Budgets}

A stream water budget for each stream reach, as well as the leakage rate between a stream reach and corresponding model cell, is computed each iteration of a time step and at the end of each time step. These calculations are made independent of the ground-water model budget. The water budget of the first reach in a segment is computed by determining all the inflows and outflows to the first reach. Any flow out of the first reach is then routed to the next downstream reach or second reach, where a new water budget is determined for that reach; flow out of the second reach is then routed to the next downstream reach or third reach, and the process is continued to the last reach in the segment. Flow out of the last reach of a segment is saved and used as inflow to the next downstream segment, or it is allowed to the leave the modeled area if the last reach in the segment exits the modeled area or if the segment is not connected to any other segments (for example, if all the water is routed into a lined canal or sealed pipeline).

The water budget of each stream reach is used to determine the quantity of streamflow available to leak into the aquifer during each time step. For example, if flow into the reach from all sources is zero (the stream is dry), then no leakage is allowed from that reach into the underlying aquifer. However, if the head in the underlying aquifer is greater than the streambed, then ground-water flow into a reach of zero flow is computed, and the stream then begins to flow in that reach during the time step. Additionally, the outflow from a reach can be less than the leakage to ground water in the next downstream reach and, if streamflow into the downstream reach from all sources (outflow from upstream reach, overland runoff, and precipitation) is less than the computed quantity of leakage through the streambed, then the leakage across the streambed is limited to the available streamflow in the reach and the stream then goes dry (there is no outflow from that reach).

The program allows several sources of inflow to a stream reach. These sources include a specified inflow at the beginning of the first reach of any segment $\left(Q_{s r i}\right)$; the sum of tributary flow from upstream segments into the first reach of a segment $\left(Q_{t r b}\right)$; direct overland runoff to a reach $\left(Q_{r o}\right)$, precipitation that falls directly on a reach $\left(Q_{p p t}\right)$; and ground-water leakage to a reach calculated by the model $\left(Q_{L i}\right)$.

$$
\sum Q_{i n}=Q_{s r i}+Q_{t r b}+Q_{r o}+Q_{p p t}-Q_{L i}
$$

All terms are in units of volume per time. The term $Q_{L i}$ is subtracted from the other terms because ground-water flow to a stream reach (a source of water to a stream reach) is a negative value (discharge from ground water is negative in MODFLOW). The program also allows for several losses from a stream reach. These losses include streamflow out of a reach $\left(Q_{s r o}\right)$; specified diversions from the last reach in a segment $\left(Q_{d i v}\right)$; evapotranspiration from a reach $\left(Q_{e t}\right)$; and leakage to the underlying aquifer $\left(Q_{L o}\right)$.

$$
\sum Q_{\text {out }}=Q_{\text {sro }}+Q_{d i v}+Q_{e t}+Q_{L o} .
$$

The term $Q_{L o}$ is added to the equation only when a stream reach loses flow to the aquifer (recharge to ground water is a positive value). For each reach, the sum of flows (in units of volume per time) into the reach $\left(\sum Q_{i n}\right)$ is equal to the sum of flows out of the reach $\left(\sum Q_{\text {out }}\right)$ :

$$
\sum Q_{\text {in }}=\sum Q_{\text {out }} .
$$

Specified inflows and outflows are defined only for the first and last reach of a segment. Constant flows into a segment can be specified for the first reach of a segment. This specified flow can represent streamflow entering the first reach in the modeled area or it can be used to represent localized discharge into a stream (for example, from a pipeline) within the modeled area. For segments within the modeled area, the specified flow can be negative, in which case the flow would be subtracted from any incoming upstream segments (see figure 3 for an example of a point diversion into a pipeline). Tributary inflows to a segment are computed by the program by summing all outflows from upstream segments that are tributary to a particular downstream segment. Diversions can be simulated only from the last reach of any segment. The quantity of flow to a diversion (such as an unlined canal or ditch) can be specified at a fixed rate or as a percentage of flow out of the last reach in the segment.

Uniform overland flow (volume per time) can be specified for any segment. This volumetric flow rate is prorated for each reach in the segment on the basis of the fraction of the specified reach length to the total segment length. Also, uniform precipitation and evapotranspiration rates (units of length per time) can be specified for each segment. Volumetric precipitation and evapotranspiration rates for each reach within the segment are then computed by multiplying each rate by the reach length and width.

\section{Computing Stream Depth}

Stream depth is used in the program to compute the head in each reach by adding stream depth to the top of the streambed for each reach. Stream depth is computed at the midpoint of each reach. Unless a constant stream depth is specified, flow at the midpoint $\left(Q_{m d p t}\right)$ is computed prior to computing stream depth. Flow at the midpoint is computed as: 


$$
Q_{m d p t}=Q_{s r i}+Q_{t r b}+0.5\left(Q_{r o}+Q_{p p t}-Q_{e t}-Q_{L}\right),
$$

where $Q_{L}$ is the leakage through the streambed and includes leakage from the stream reach to the aquifer $\left(Q_{L o}\right)$ and from the aquifer to the stream reach $\left(Q_{L i}\right)$. The leakage term is positive when leakage is from the stream reach to the aquifer and negative when leakage is from the aquifer to the stream reach, hence it is subtracted from the other terms.

Because flow at the midpoint of a reach is partly dependent on streambed leakage, which is dependent on stream depth and, therefore, on flow, equation 3 is nonlinear, and is solved iteratively using Newton's method or Newton-Raphson method (Burden and Faires, 1997, p. 65) until the root of the equation is estimated within a specified tolerance. In some reaches, oscillations may develop between iterations when the stream head (stream depth plus streambed elevation) nearly equals the head in the aquifer, and leakage across the streambed oscillates between a positive and a negative number. When this occurs, a warning is printed in the main listing file for that reach giving the last two values of stream depth and its effect on streambed leakage. The simulation continues by taking the average stream depth of the last two oscillations (usually, the program oscillates between the same two numbers; one positive and one negative). If the oscillations are persistent through the model simulation, increasing the streambed thickness generally reduces the oscillations.

Five options for computing stream depth for a reach have been included in the program. A different option can be used for each segment. All five options use the same method for determining the elevation of the streambed in each reach. The elevation of the top of the streambed is specified for the beginning of the first reach and the end of the last reach. The program linearly interpolates between the two values. This differs from the STR1 Package in which the top and bottom elevation of the stream bed was specified for each reach. Finally, because stream depth for each reach is computed on the basis of streamflow in each reach, and added to streambed elevation to obtain a stream head, the user is responsible for checking that stream heads do not change unreasonably (increase in a downstream direction) between reaches and among segments.

The first two options for computing stream depth are the same as those used in STR1, except that stream depth is now computed for the midpoint of the stream reach. The first option allows the user to specify a stream depth for the first and last reach of a segment. The program then linearly interpolates between the two values using the same method for estimating the top of the streambed.

The second option uses Manning's equation to determine depth as a function of flow:

$$
Q=\left(\frac{C}{n}\right) A R^{2 / 3} S_{0}{ }^{1 / 2},
$$

where

$Q$ is stream discharge, in units of volume per time;
$C$ is a constant, which is 1.0 for units of cubic meters per second or 1.486 for units of cubic feet per second;

$n$ is Manning's roughness coefficient, dimensionless;

$A$ is cross-sectional area of the stream, units of length squared;

$R$ is hydraulic radius of the stream, in units of length; and

$S_{0}$ is slope of the stream channel, in units of length per length.

Assuming a wide rectangular stream channel in which the stream width is much greater than the stream depth, Manning's equation can be simplified to:

$$
Q=\left(\frac{C}{n}\right) w y^{5 / 3} S_{0}{ }^{1 / 2}
$$

where

$w$ is width of channel, in units of length; and

$y$ is depth of water in stream, in units of length.

Solving for depth yields:

$$
y=\left[\frac{Q n}{C w S_{0}{ }^{1 / 2}}\right]^{3 / 5} .
$$

The third option also uses Manning's equation but the channel geometry is divided into an eight-point cross section. The cross-section geometry is assumed to be the same in all reaches in a segment. Horizontal distances and vertical elevations are specified for each of the 8 points along the cross section. Horizontal distances are relative to the left edge of the cross section (viewed in downstream direction). Vertical distances are relative to the specified streambed elevation (lowest point or thalweg in the channel). Eight values each for the horizontal and vertical distances are specified for the segment. Vertical walls are assumed at the end of each cross section. Stream depth, width, and wetted perimeter are computed from the cross section for a given flow using Manning's equation and by dividing the cross section into three parts (fig. 4). A different value of Manning's roughness coefficient can be used in the calculations for parts 1 and 3 (to represent overbank flow) from that used in part 2.

Because the area $(A)$ and hydraulic radius $(R)$ in Manning's equation can be complicated functions of depth (particularly for natural channels), no general analytical solutions are available for solving depth for an 8-point cross section given the volumetric flow rate (Chow and others, 1988, p. 160). Therefore, a numerical method is used to compute stream depth. A mixed bisection-secant method (Burden and Faires, 1997, p. 72) is used for computing depth and is a modification to the method used by the U.S. Army Corps of Engineers in their Hydrologic Modeling System (Paul Ely, U.S. Army Corps of Engineers, Davis, Calif., 1997, written commun.). 


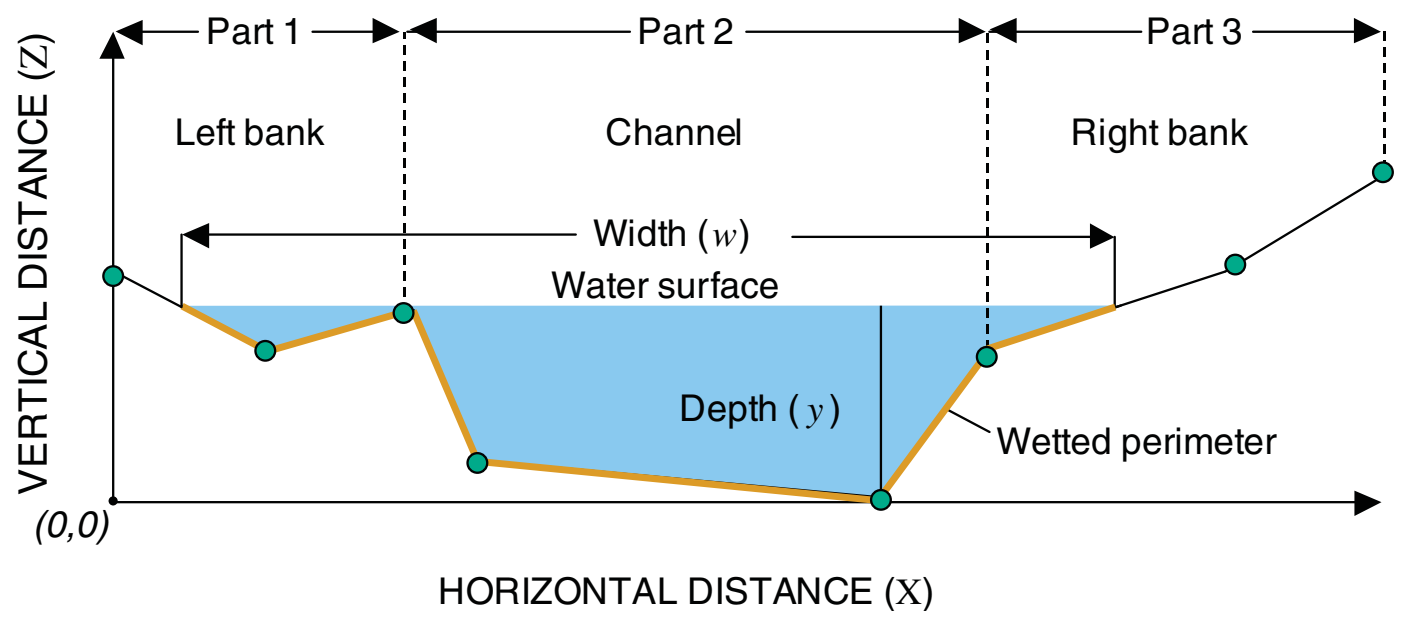

Figure 4. An eight-point cross section used to compute depth, width, and wetted perimeter for a stream segment. (Note: stream cross section is viewed looking downstream.)

Depth $(y)$ is solved by iteratively computing flow for an estimated depth until the difference between computed flow $\left(Q_{n}\right)$ and streamflow at the midpoint of the reach $\left(Q_{m d p t}\right)$ are acceptably small. The generalized form of the equation used to determine stream depth is (Burden and Faires, 1997, p. 70):

$$
y_{n}=f\left(y_{n-1}\right)-\frac{f\left(y_{n-1}\right)\left(y_{n-1}-y_{n-2}\right)}{f\left(y_{n-1}\right)-f\left(y_{n-2}\right)},
$$

where

$n$ is the iteration number;

$f\left(y_{n-1}\right)$ is $Q_{n-1}-Q_{m d p t}$ for depth $y_{n-1}$; and

$f\left(y_{n-2}\right)$ is $Q_{n-2}-Q_{m d p t}$ for depth $y_{n-2}$.

The procedure starts with two initial estimates of depth $\left(y_{0}\right.$ and $\left.y_{1}\right)$ as shown on figure 5 . The bisection method initially is used to bracket the interval around the actual depth $(y)$. The bisection method simply halves the difference between the two initial depths $\left(y_{2}\right.$ in figure 5). The depth $y_{2}$ is used to determine if the function $f\left(y_{n}\right)$ is positive (depth greater than actual) or negative (depth less than actual). In the example shown in figure $5, f\left(y_{2}\right)$ is negative and the actual depth lies between $y_{2}$ and $y_{1}$ so $y_{0}$ is replaced by $y_{2}$. The two depths that define the new interval are then used in the secant method to estimate a new depth $\left(y_{3}\right.$ in figure 5) by determining the intercept of the line joining the two bracketing depths ( $y_{2}$ and $y_{1}$ in figure 5). The new estimate $\left(y_{3}\right)$ is checked to determine if the function $f\left(y_{n}\right)$ is negative or positive. In the example shown in figure $5, y_{3}$ is negative and it then replaces $y_{2}$ as the lower limit of the bracket. The process of finding a new depth is repeated ( $y_{4}$ in figure 5). The process is repeated until the depth $\left(y_{n}\right)$ produces a computed flow $\left(Q_{n}\right)$ that is within an acceptable error of streamflow at the midpoint of each reach $\left(Q_{m d p t}\right)$.

This method may not solve stream depth for all geometries. An error message is printed whenever the method has failed to converge to within a reasonable tolerance. For example, if the channel has a wide, flat bottom, small changes in

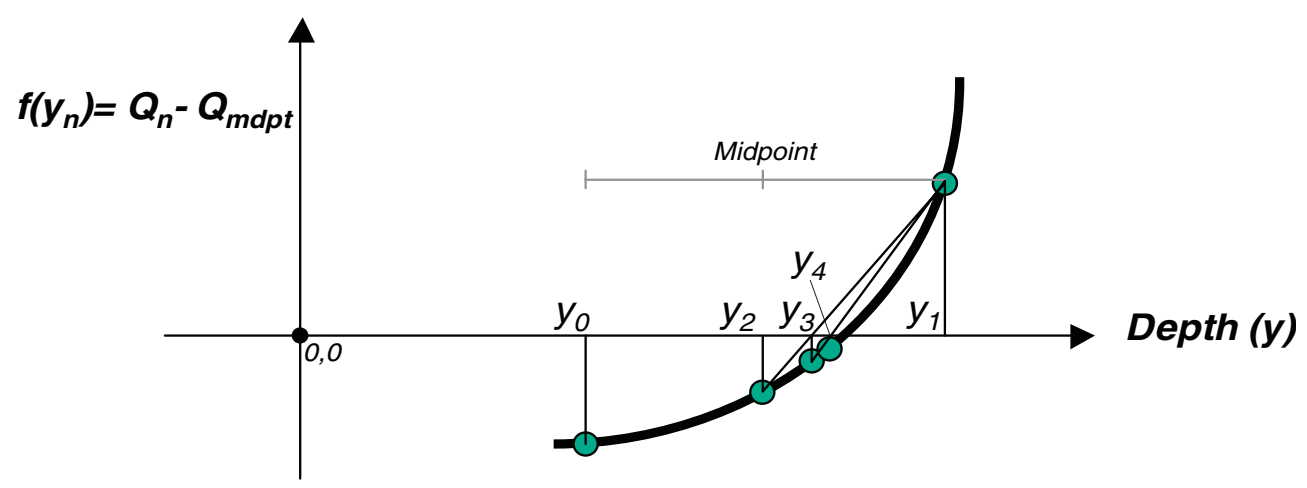

Figure 5. Bisection-secant method used to determine depth of stream from Manning's equation assuming an eight-point cross section (modified from Burden and Faires, 1997, p. 71). From Numerical Analysis $6^{\text {th }}$ edition by BURDEN/FAIRES c 1997. Reprinted with permission of Brooks/ Cole, a division of Thomson Learning: www.thomsonrights.com. 
stream depth can cause large changes in flow, and the method may fail to converge. For such geometries, other options may provide better estimates of depth.

The fourth option uses depth-discharge and width-discharge relations for estimating stream depth and width as a function of flow. Stream depth and width generally increase at a stream cross section as a power function of increasing streamflow (discharge). The fourth option assumes that stream depth and width can be related to streamflow by equations of the form (Leopold and others, 1992, p. 215):

$$
y=c Q^{f} \quad w=a Q^{b},
$$

where $Q$ is streamflow (discharge), and variables $a, b, c$, and $f$ are numerical coefficients determined from regression methods. The regressions are typically done at streamflow gaging stations. As with the other options, the relations between depth and streamflow and width and streamflow are evaluated at the midpoint of each reach. Representative values of the numerical coefficients for selected regions of the United States are listed in Leopold and others (1992, table 7-5, p. 244).

The fifth option allows the user to enter values of depth and width for given streamflows on the basis of observations at a streamflow gaging station. The program uses the tabulated values to interpolate stream depths and widths for modelcalculated streamflow. Stream depth and width are determined by interpolating between two streamflow (discharge) values that bracket the computed flow at the reach midpoint. Values of streamflow, depth, and width are converted into their logarithms prior to interpolating between the two known values. If the computed flow is between the lowest tabulated value and zero flow, a simple linear interpolation between zero flow and the lowest tabulated flow is used to determine depth and width. If the computed flow is above the highest tabulated flow value, an error message is printed, and the program continues by extrapolation from the log values of the highest two tabulated values of flow, depth, and width.

\section{Diverting Streamflow}

Several options are available for diverting water from modeled stream channels. The simplest form of a diversion is a specified flow (negative discharge) that is removed from the channel at the beginning of the first reach of a segment. Water from this type of diversion does not interact with ground water through a leakage term. For diversions of this type, it is assumed the water is placed in a non-leaking pipe or a lined canal (example of such a point diversion is shown in figure 3 ). Flow contributed by such a diversion could be added elsewhere by specifying flow (positive discharge) at the beginning of another segment.

If a diversionary flow is large enough to warrant representation in the model, but is discharged into a pipeline, lined canal, or other structure or system that does not interact with the aquifer and the flow might exceed the available streamflow, then there is an alternative means to represent it. A single-reach diversionary stream segment can be assigned to the same model cell as the upstream segment from which flow is to be diverted. Ground-water interaction with this single-reach diversionary segment can be precluded by assigning a hydraulic conductivity of zero and outflow to a non-defined segment (for example; segment 0 ). Diversion of water into the segment would then be subject to the constraints associated with the type of diversion specified as described in the following paragraph.

Four other types of diversions route flows through channels in the same manner as a stream. Water entering a diversion is subtracted from the end of the last reach of a segment; any remaining flow at the end of the last reach of a segment is added as tributary inflow at the beginning of the first reach in the next downstream segment. The first option (which is the default condition) assumes that all available flow at the end of the last reach of a segment up to the rate specified will be diverted from the segment. Thus, if flow in the stream is less than the specified diversion, all available flow in the stream will be diverted, and none will remain in the channel. This option is common to many diversions in the western United States. The second option allows for the specified diversion only if flow in the stream is greater than that of the diversion, if flow is less than the specified diversion, no flow is diverted and all flow remains in the channel. This option is the same as that specified in the STR1 (Prudic, 1989, p. 5). The third option diverts a specified fraction of the available flow, and the fourth option diverts all flow in excess of a specified rate. The fourth option typically is used for flood control in which all excess flow is diverted away from the main channel during peak discharge. The last two options are from Danskin and Hanson (2002).

\section{Stream-Lake Interconnections}

The SFR1 Package and the LAK3 Package (Merritt and Konikow, 2000) have been developed to accommodate streams that discharge water into lakes. Any number of inlet streams can discharge into a lake or series of lakes. Outflow from the last reach of a stream segment is used as inflow to a lake. Stream inflow to a lake (as reported by the LAK3 Package) is the sum of all streams that enter it. The SFR1 and LAK3 Packages also accommodate streams that emanate from lakes. Outflow from a lake becomes inflow to the first reach of a stream segment. Outflow from a lake to a stream can be specified or, if unknown, it can be computed. When outflow from a lake is unknown or varies as a function of lake stage (lake-water level), the outflow from a lake and therefore inflow to a stream is computed by using the lake stage as the head at the beginning of the first reach of a stream segment whose source of flow is the lake. Outflow from the lake and flow into the stream is computed by subtracting the elevation of the top of the streambed at the beginning of the first stream reach from the lake stage $\left(h_{l}\right)$. This depth is used to compute outflow from the lake (and inflow to a stream segment) by solving for flow instead of depth using one of the specified options for computing stream depth (wide-rectangular 
channel, eight-point cross section, or depth-discharge and width-discharge relations).

For steady-state simulations that couple both the SFR1 and LAK3 Packages, lake stage is dependent on outflow from the lake and, conversely, flow into the first reach of a stream segment is dependent on lake stage. The mathematical technique used to solve the steady-state simulation of lake stage and outflow to a stream is Newton's method (Merritt and Konikow, 2000 , p. 12). Like the secant method used for solving the Manning's equation with an 8-point cross section, Newton's method is an iterative technique for obtaining the root (or zero) of a function (in this case $f\left(h_{l}\right)$, where $h_{l}$ is the lake stage) that has a continuous derivative $f^{\prime}\left(h_{l}\right)$ (Merritt and Konikow (2000, p. 12, eq. 13). At the zero values for $f\left(h_{l}\right)$, the inflows and outflows from the lake are in balance; that is, the lake stage is in equilibrium given the prevailing hydrologic conditions. One of the terms of the derivative $f^{\prime}\left(h_{l}\right)$ is the derivative of the outflow rate from the lake to a stream (that is, streamflow from the lake),

$\frac{d}{d h_{l}} Q_{s o}\left(h_{l}\right)$. The form of the derivative of $Q_{s o}\left(h_{l}\right)$ depends on

the method used to compute streamflow in the first reach of a stream segment whose source is outflow from a lake. When the method used is based on Manning's equation for a wide rectangular channel (equation 5 of this report), the derivative of stream outflow from the lake is (modified from Merritt and Konikow, 2000, p. 12, eq. 15):

$$
\frac{d}{d h_{l}} Q_{s o}\left(h_{l}\right)=\frac{d}{d h_{l}}\left[\frac{C}{n} w\left[h_{l}-h_{b}\right]^{5 / 3} S_{0}{ }^{1 / 2}\right]=\frac{5}{3} \frac{Q_{s o}}{y},
$$

where

$Q_{s o}$ is lake outflow to stream, in units of volume per time;

$h_{l}$ is the lake stage, in units of length;

$h_{b}$ is elevation of the top of the streambed, in units of length; and

$y$ is stream depth, which equals difference between lake stage $\left(h_{l}\right)$ and elevation of streambed $\left(h_{b}\right)$, in units of length.

The derivative for the other methods used to compute stream discharge from a lake is approximated for each iteration of Newton's method from the slope of the stage-discharge relation, for values of lake stage close to the most recent approximation of lake stage. For computing stream depth using option 5 , the slope is determined from the log interpolation of the tabulated values unless the inflow stream depth is below the lowest tabulated stream depth, in which case the slope is based on a simple linear interpolation between zero depth and the first tabulated depth.

\section{Solute Transport}

When the SFR1 Package and the GWT Process are active, solute transfer between the stream and the aquifer is simulated. Where the stream is losing water to the aquifer, solute in the stream water will mix with the water in the underlying aquifer. The concentration in the aquifer will change if the concentration in the stream is different from that in the aquifer. In areas where the stream is gaining water because of ground-water discharge, the solute concentration in the stream will be affected by the rate and solute concentration of ground-water inflow. Solute in a stream also will be transported downstream, and its concentration may be affected by other inflows to the stream or may affect the concentration in the aquifer. The SFR1 Package in conjunction with MODFLOW-GWT includes the capability to account for the exchange of solute between the stream and the aquifer, and to route solute downstream while adjusting concentrations in the stream to account for inflows and outflows to the stream from ground water, tributaries, lakes, and other specified inflows and outflows.

When the GWT Process is active, the model will compute the concentration of a solute at every node within the transport domain (which can encompass all, or only part, of the MOD-

FLOW grid). If there is leakage between the stream and the aquifer in a model cell in which concentration is calculated, then the solute flux between the stream and the aquifer also can be calculated. Just as streamflow can be routed downstream by accounting for the sequential gain and loss of flow at successive model cells, the same can be done for the solute flux. The solute concentration is calculated along the stream channel starting with a user-specified input concentration in the specified inflow, and adjusted sequentially in a downstream direction by accounting for solute inputs and (or) outputs at each successive reach.

The same assumptions that are used to route flow through a stream network are used to route solutes in the network. The most important assumption is that flow velocities in a stream are much faster than those in a ground-water system; therefore, it is assumed that complete flushing of stream reaches occurs during each time step of the ground-water model and that the volume of water in storage in a stream reach is small relative to the amount of flow through the reach during a time step. Hence, the concentration in water leaving a stream reach can be related to concentrations in the flows to that reach, and the initial concentration in the reach at the start of a time step can be ignored. An example of solute transport using the SFR1 and LAK3 Packages is provided later in the document (Test 2).

A simple mixing equation, similar to that described by Konikow and Bredehoeft (1974), is used to calculate the solute concentration in the streamflow discharging from a stream reach assuming: (1) complete and instantaneous mixing within the stream volume of all inflows to an individual stream reach; (2) the time scale of changes in the ground-water system is substantially longer than the time scale of changes in the streamflow; and (3) there are no reactions in the stream that affect solute concentration.

If there is no change in solute mass stored within a stream reach, the sum of all solute mass entering a stream reach must equal the sum of all solute mass leaving a stream reach during 
each time increment. For a solute, this simple mass-balance statement may be expressed as:

$$
\sum Q_{i} C_{i}=\sum Q_{o} C_{o},
$$

where $C$ is the solute concentration, in units of mass per volume and $Q$ is the fluid flow, in units of volume per time; the subscript $o$ refers to flow out of the reach; and the subscript $i$ refers to flow into the reach.

Expanding terms to account for all components of inflow and outflow yields:

$$
\begin{gathered}
Q_{s r i} C_{s r i}+Q_{t r b} C_{t r b}+Q_{r o} C_{r o}+Q_{p p t} C_{p p t}-Q_{L i} C_{g w} \\
=Q_{s r o} C_{s r o}+Q_{d i v} C_{s r o}+Q_{e t} C_{e t}+Q_{L o} C_{s r o},
\end{gathered}
$$

where the flow terms are the same as presented in equations $2 \mathrm{a}$ and $2 \mathrm{~b} ; Q_{L i}$ on the left side of equation 12 is nonzero only when leakage is from the aquifer to the stream reach, whereas $Q_{L o}$ on the right side of equation 12 is nonzero only when leakage is from the stream reach to the aquifer. Concentration of water entering a diversion is assumed to have the same concentration as water at the end of the reach $\left(C_{s r o}\right)$. Also, when the stream reach is losing water to the aquifer, the concentration in that water is assumed equal to the concentration in the streamflow out of the reach (that is, $C_{s r o}$ ).

Note that for simplicity, the evaporative flow directly out of a stream is assumed to contain no solute (that is, $C_{e t}=0.0$ ) and that evaporation consequently will increase the solute concentration in the water left in the stream. For reaches in which the stream is losing water to the aquifer, the flow out of the reach includes both surface-water outflow $\left(Q_{\text {sro }}\right)$ and groundwater leakage $\left(Q_{L o}\right)$. The concentration of the outflow would be the same in both the surface water and ground-water outflow components (as indicated on the right side of equation 12). In this case, the solute concentration leaving a stream reach, as surface outflow at the end of the reach $\left(Q_{\text {sro }}\right.$ and $\left.Q_{\text {div }}\right)$, as leakage from the stream reach to the aquifer $\left(Q_{L o}\right)$, or both, may be calculated as:

$$
C_{s r o}=\frac{Q_{s r i} C_{s r i}+Q_{t r b} C_{t r b}+Q_{r o} C_{r o}+Q_{p p t} C_{p p t}}{Q_{s r i}+Q_{t r b}+Q_{r o}+Q_{p p t}-Q_{e t}} .
$$

For a reach in which the stream is gaining water from the aquifer, only two terms $\left(Q_{\text {sro }}\right.$ and $\left.Q_{\text {div }}\right)$ are multiplied by the concentration at the end of the reach $\left(C_{\text {sro }}\right)$. Substituting individual components in place of $Q_{\text {sro }}$ and $Q_{\text {div }}$ (where $\left.Q_{\text {sro }}+Q_{\text {div }}=Q_{s r i}+Q_{t r b}+Q_{r o}+Q_{p p t}-Q_{e t}-Q_{L i}\right)$ and solving for $C_{s r o}$, yields a calculated solute concentration leaving a stream reach as:

$$
C_{s r o}=\frac{Q_{s r i} C_{s r i}+Q_{t r b} C_{t r b}+Q_{r o} C_{r o}+Q_{p p t} C_{p p t}-Q_{L i} C_{g w}}{Q_{s r i}+Q_{t r b}+Q_{r o}+Q_{p p t}-Q_{e t}-Q_{L i}}
$$

When a stream segment originates as a diversion, then $C_{s r i}$ for the first reach of that segment is defined as being equal to $C_{\text {sro }}$ of the reach from which the diversion is taken. When a stream segment originates as inflow from tributaries, then $C_{t r b}$ for the first reach of that segment is calculated from the sum of the product of the inflows and their concentrations of all tributaries feeding that segment, as indicated by:

$$
C_{t r b}=\frac{\sum_{i=1}^{n t r i b}\left(Q_{t r b} C_{t r b}\right)_{i}}{\sum_{i=1}^{n t r i b}\left(Q_{t r b}\right)_{i}},
$$

where $n t r i b$ is the number of tributaries feeding the segment.

A stream reach may be located at a cell where the aquifer concentration is unknown and undefined because the solutetransport equation might be solved only within a subgrid of the primary MODFLOW grid (or domain). For parts of the stream network that lie outside of the transport subgrid, the solute concentration in the stream is assumed not to change as a result of leakage across the streambed. That is, the solute concentration in the ground water is assumed the same as the surface inflow at the beginning of the stream reach, whereby $C_{g w}=\left(Q_{s r i} C_{s r i}+Q_{t r b} C_{t r b}\right) /\left(Q_{s r i}+Q_{t r b}\right)$, regardless of whether the stream is gaining or losing in that reach. This allows solute concentration in the stream to be routed through reaches that lie outside of the transport subgrid, and any change in solute concentration in the stream would only be caused by simple dilution (or mixing) effects related to tributary inflows, added streamflow (such as a point source), precipitation, evapotranspiration, and runoff. An example of such an application is where a stream leaves the transport subgrid a small distance before meandering back to lie within the subgrid. This feature to allow continuity of routing outside of the transport subgrid assures that the model will run successfully for such cases. However, if there are any significant ground-water inflows of solute outside of the transport subgrid, then this approximation will not be appropriate, and the transport subgrid should be expanded to include the area of interest.

To obtain a solution to the ground-water solute-transport equation where the stream is losing water to the aquifer, it is necessary to use the stream routing algorithm to define $C_{j, i, k}^{\prime}$, where $C_{j, i, k}^{\prime}$ is the concentration in a fluid source (in this discussion, leakage from a stream reach) to cell $j, i, k$ (see Konikow and others, 1996, eq. 55). When stream leakage is into the aquifer, $C_{j, i, k}^{\prime}=C_{s r o}$ and equation 13 is solved at the beginning of each time increment used to solve the transport equation, but after a solution to the ground-water flow has been obtained. This allows us to define the value of $C_{j, i, k}^{\prime}$ in stream infiltration for the solution to the solute-transport equation for the end of the current time increment. However, in solving equation 14 at the start of a transport time increment, the concentration of water entering the stream from the ground-water system $\left(C_{g w}\right)$ is assumed to equal the concentration in the aquifer at that cell at the end of the previous time increment.

In order to solve the ground-water solute-transport equation accurately, it is common for transport time increments to be smaller than the length of the time step used to solve the groundwater flow equation. In such cases, the leakage between the stream and the aquifer calculated for the flow time step is applied to every transport time increment during that flow time 
step, but the concentrations in the stream and in the aquifer are updated more frequently. Thus, transport within the aquifer and stream is updated every transport time step, whereas leakage across the streambed is updated every flow time step.

In the mass-balance calculations for MODFLOW-GWT, the solute mass flux ( $m$, in units of mass) between the stream reach and aquifer cell for a stream reach that is gaining water from the aquifer during a given time increment is assumed to equal the flow rate $\left(Q_{L i}\right)$ times the average concentration in the aquifer cell between the start and end of the time increment $\left[\left(C_{j, i, k}^{n-1}+C_{j, i, k}^{n}\right) / 2\right]$, where $C_{j, i, k}^{n-1}$ is the concentration of ground water in the aquifer cell $j, i, k$ at the start of the time increment and $C_{j, i, k}^{n}$ is the concentration of ground water in the aquifer cell at the end of the time increment. That is,

$$
m=\left[\left(C_{j, i, k}^{n-1}+C_{j, i, k}^{n}\right) / 2\right] Q_{L i} \Delta t,
$$

where $\Delta t$ is the time difference from the beginning to the end of the time increment.

\section{Assumptions and Limitations}

One limitation of the SFR1 Package is that the method used to compute stream depth and wetted width at the midpoint of each stream reach may not always converge to a stable solution because of the dependency between computed stream head and leakage that is solved using Newton's method. Oscillations are more common when stream head is nearly the same as that in the aquifer and flow across the streambed oscillates between adding water to the aquifer and discharging water from the aquifer. The solution of stream depth at the midpoint of a reach was desired because several new options were added to the SFR1 Package that were not available in the STR1 Package. The SFR1 Package computes stream head and leakage across the streambed differently than the STR1 Package. In the STR1 Package, head in the stream was either fixed or computed on the basis of inflow to the reach. Leakage to or from the ground-water system was computed over the entire reach and added to or subtracted from inflow into the reach. Thus, stream head in a reach was not dependent on the leakage across the streambed within the reach. In the SFR1 Package, head in the stream is computed at the midpoint of the reach within a model cell and includes half the precipitation, evapotranspiration, overland runoff, and leakage across the streambed that occurs within the reach.

Another limitation that needs to be considered when using the SFR1 Package is that streamflows and solute concentrations are routed between stream reaches based only on continuity. This means that during each model time step, volumetric inflow and outflow rates are equal for each stream reach, that no water (or solute) is added to or removed from storage in the surface channels, and that any water or solute that enters the aquifer by leakage in a losing stream reach is not routed to the next downstream reach of the stream. The SFR1 Package was designed to model long-term changes (months to hundreds of years) in ground-water flow and solute transport using averaged flows in streams. The continuity approach taken in the SFR1 Package has general applicability because ground-water flow velocities are usually much less than flow velocities in open channels. The SFR1 Package is not recommended for modeling the transient exchange of water between stream reaches and shallow ground water when the objective is to examine short-term (minutes to days) effects caused by rapidly changing streamflows or rapidly changing solute source terms. Moreover, the assumption that a solute is completely mixed within each stream reach has general applicability for many small streams but may not be applicable for modeling all streams or large rivers.

The assumption that leakage through the streambed is transmitted to the water table instantaneously when the aquifer head is below the bottom elevation of the streambed generally limits the applicability of the SFR1 Package to the simulation of transient leakage through thin unsaturated or nearly saturated zones beneath streams. This assumption may not be reasonable for some intermittent or ephemeral channels in which the water table is tens to hundreds of feet or meters below the streambed. Also, when the water table is below the bottom of the streambed, flow across the streambed is dependent on the head difference across the streambed (the difference between the head in the stream and the bottom of the streambed), and the rate of leakage is not dependent on deposits or rocks beneath the streambed even when gradients across the streambed exceed one. Careful consideration of the head gradient across the streambed, and of the thickness of the streambed, is needed to minimize simulations with unrealistically large leakage rates when the water table is below the streambed. The head gradient across the streambed is reported for each reach and can be used to check that the computed leakage rates are realistic.

The added complexity of allowing the area of the streambed to change as a function of flow at the midpoint of a stream reach, which affects the leakage rate through the streambed, increases numerical instability. Instability is greatest for steady-state simulations because the ground-water storage term is zero and for simulations in which the streambed conductance term is high relative to the aquifer conductivity, especially when the head difference between the stream and aquifer is small.

For complex models with many stream reaches, differences in the timing and response among individual stream reaches with their corresponding model cells caused by variations in streamflow, ground-water pumping and solute concentration may require more time steps to adequately simulate the exchange of water and solute for all model cells with a stream reach. Because of the difficulty in knowing how and when changes in the head difference between a stream reach and corresponding model cell will result in large changes in leakage rates or in solute concentrations, the user is cautioned to check stream leakage and solute concentrations for all stream reaches to make certain that sufficient time steps have been used to adequately simulate changes in all reaches.

Diversions from stream reaches require knowledge as to when and where such diversions occur. Although the overall structure of the SFR1 Package has been designed to allow for the hierarchical ranking (or priority) of a diversion relative to other 
diversions in the overall stream network (this is analogous to water rights that have priorities in time under the regulations of many western states), the coding for such a capability will be implemented in a later version.

If the solute-transport equation is solved using one of the particle tracking algorithms, then special attention must be given to the specification of fluid sources or sinks as being either "strong" or "weak." This information is specified in Data Set 13 of the input data file for MODFLOW-GWT (see Kipp and others, 1998, or Konikow and others, 1996). Although some trial and error adjustments may be required, in many cases it is a reasonable first approximation to assume that all stream reaches represent strong fluid sources or sinks. This would require setting IGENPT $=1$ at all nodes corresponding to stream cells when using the MOC or MOCIMP solver options.

\section{Test Simulations}

Results from two tests are presented to illustrate the features of the SFR1 Package. Instructions for data input into the SFR1 Package are presented in Appendix 1. The first test uses two simulations (one steady-state and one transient) to illustrate the long-term effects of ground-water withdrawals in an alluvial basin on the flow in streams. The second test is a steady-state flow simulation of a connected stream and lake that is combined with a transient transport simulation. Input data and model output for the two test simulations are available for downloading over the internet at the same site as the computer code listed in the Preface.

\section{Test 1: Stream-Aquifer Interaction}

A hypothetical problem of stream-aquifer interaction was developed for an alluvial basin in a semiarid region in which recharge to the aquifer is primarily leakage from streams that enter the basin from mountains on the northwest, northeast, and southeast (fig. 6). The principal aquifer is unconsolidated deposits of mostly sand and gravel. The mountains consist of bedrock that is many times less permeable than the unconsolidated deposits. Upland areas adjacent to the basin contribute some recharge to the aquifer either as underflow through the perimeter bedrock or from intermittent channels that have small drainage areas. The southern stream (Blue River) is perennial across the valley. Ground-water flow trends in the same direction as the streams. Ground-water evapotranspiration occurs where depth to water is within $15 \mathrm{ft}$ of land surface, has a maximum rate of $3 \mathrm{ft} / \mathrm{yr}$ at land surface, and is coincident with the valley lowland through which several streams flow. The basin fill thickens toward the center of the valley and hydraulic conductivity of the basin fill is highest in the region of the stream channels (fig. 7). Hydraulic conductivity is $173 \mathrm{ft} / \mathrm{d}\left(2 \times 10^{-3} \mathrm{ft} / \mathrm{s}\right)$ in the vicinity of the stream channels and $35 \mathrm{ft} / \mathrm{d}\left(4 \times 10^{-4} \mathrm{ft} / \mathrm{s}\right)$ elsewhere in the alluvial basin.
A model grid of the alluvial basin was divided into uniformly spaced cells 5,000 feet on each side (fig. 7). Two simulations were done to produce the results presented herein. A steady-state simulation with no pumping provided a basis for comparison to the transient simulation. The transient simulation was divided into two 50-year stress (time) periods. The first stress period simulated pumping withdrawals from ten model cells of $10 \mathrm{ft}^{3} / \mathrm{s}$ in each cell along the west side of the valley (see fig. 8) that totaled $100 \mathrm{ft}^{3} / \mathrm{s}$ (about twice the steady-state ground-water inflow). The second stress period simulated the recovery of the aquifer after all pumping withdrawals ceased. The input data files are shown in Appendix 2. Selected output is also listed in Appendix 2.

A mean annual discharge was used for the inflow rate to each stream entering the modeled area (see table 1). Streambed properties and stream dimensions used for each stream segment are also listed in table 1. Different methods were used to compute stream depth and width for each segment (see ICALC in table 1). Stream depth was computed using the tabulated values relating stream depth and width to flow for segment 1 (ICALC $=4$; values are listed in table 2); Manning's equation assuming a wide rectangular channel for segments 2,4 , and 6 (ICALC $=1$ ); constant stage for the ditch represented by segment $3($ ICALC $=0)$; power function relating stream depth and width to flow for segment 5 ( ICALC = 3); and Manning's equation assuming an eight-point cross section for segments 7 and 8 (ICALC $=2$ ). Coefficients in equation 8 used for estimating stream depth for segment 5 were $c=0.35$ (CDPTH ; Appendix 1) and $f=0.3$ (FDPTH ; Appendix 1) and coefficients in equation 9 used for estimating stream width were $a=3.8$ (AWDTH ; Appendix 1) and $b=0.6$ (BWDTH ; Appendix 1). The eightpoint cross sections for segments 7 and 8 are illustrated in figure 9 .

The strongly implicit procedure (SIP) was used to solve the flow equation for both simulations. For the steady-state simulation, a uniform initial water level of $1,050 \mathrm{ft}$ was used for all model cells. The steady-state simulation required 22 iterations within SIP to converge to a solution using a head closure criterion of $0.0001 \mathrm{ft}$ and a closure criterion (DLEAK) in the SFR1 Package of 0.01 , which corresponds to a change in stream depth between iterations of $0.01 \mathrm{ft}$. Mass balance is sensitive to both the head closure criterion in MODFLOW and to DLEAK in SFR1. Several tests of DLEAK were done ranging from 1. to 0.0001 and the maximum value which did not affect results was 0.01 . The overall MODFLOW mass-balance error was 0.01 percent. The steady-state simulation required less than $2 \mathrm{sec}-$ onds of CPU time on a personal computer having a $3 \mathrm{GHz}$ Pentium 4(R) processor and 1 GB of RAM. The transient simulation used the calculated steady-state water levels as initial heads (fig. 8). Each stress period was divided into 50 time steps with the initial time step of 15.7 days. Subsequent time steps were increased by a factor of 1.1. The maximum number of iterations in SIP for any time step was 16 using a head closure criterion of $0.001 \mathrm{ft}$ and a DLEAK of $0.01 \mathrm{ft}$. The mass-balance error for all time steps was less than 0.02 percent. The simulation required less than 4 seconds of CPU time. 


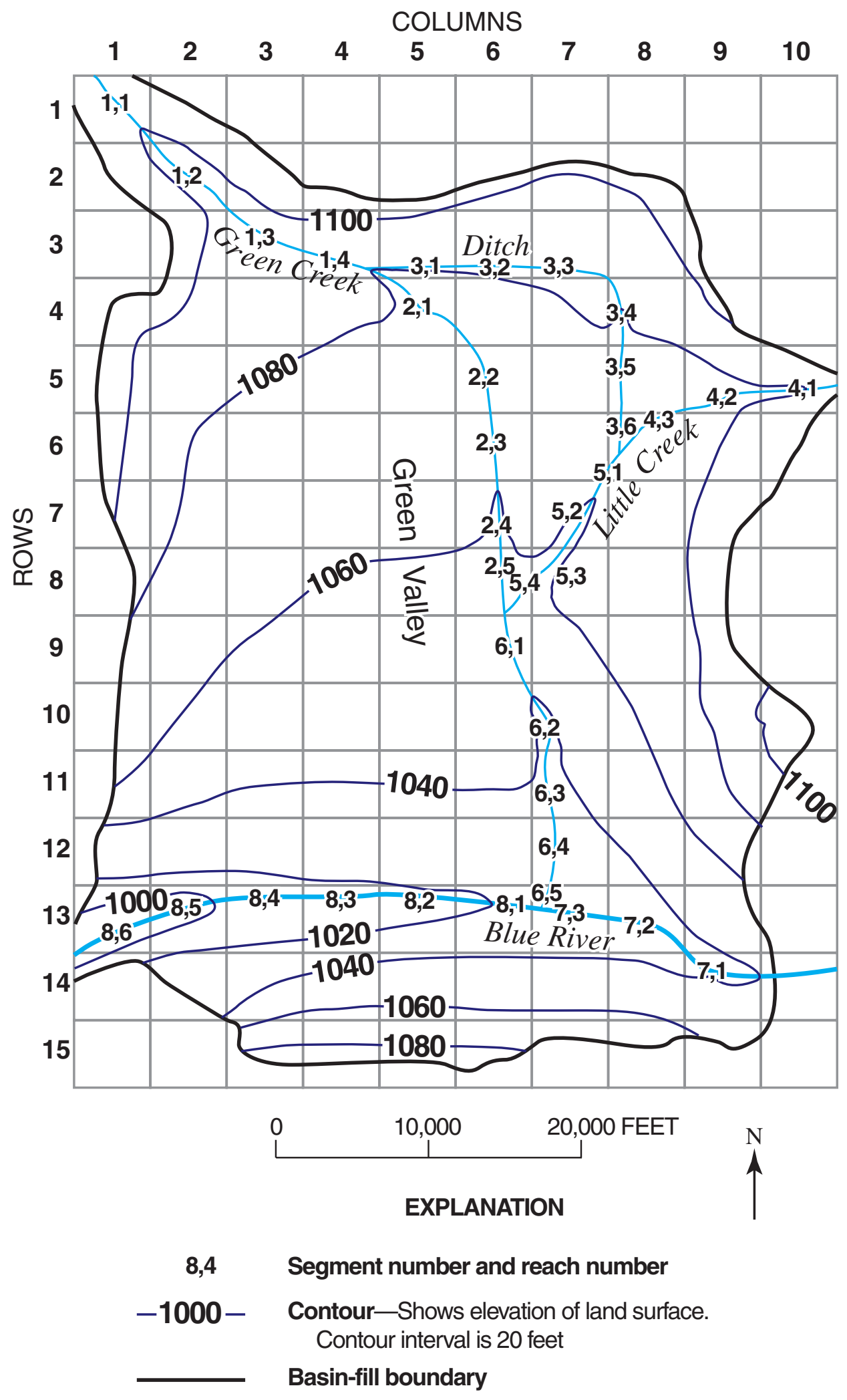

Figure 6. Hypothetical basin-fill aquifer with model grid, land-surface contours, and stream segment and reach numbering scheme for test simulation 1. 


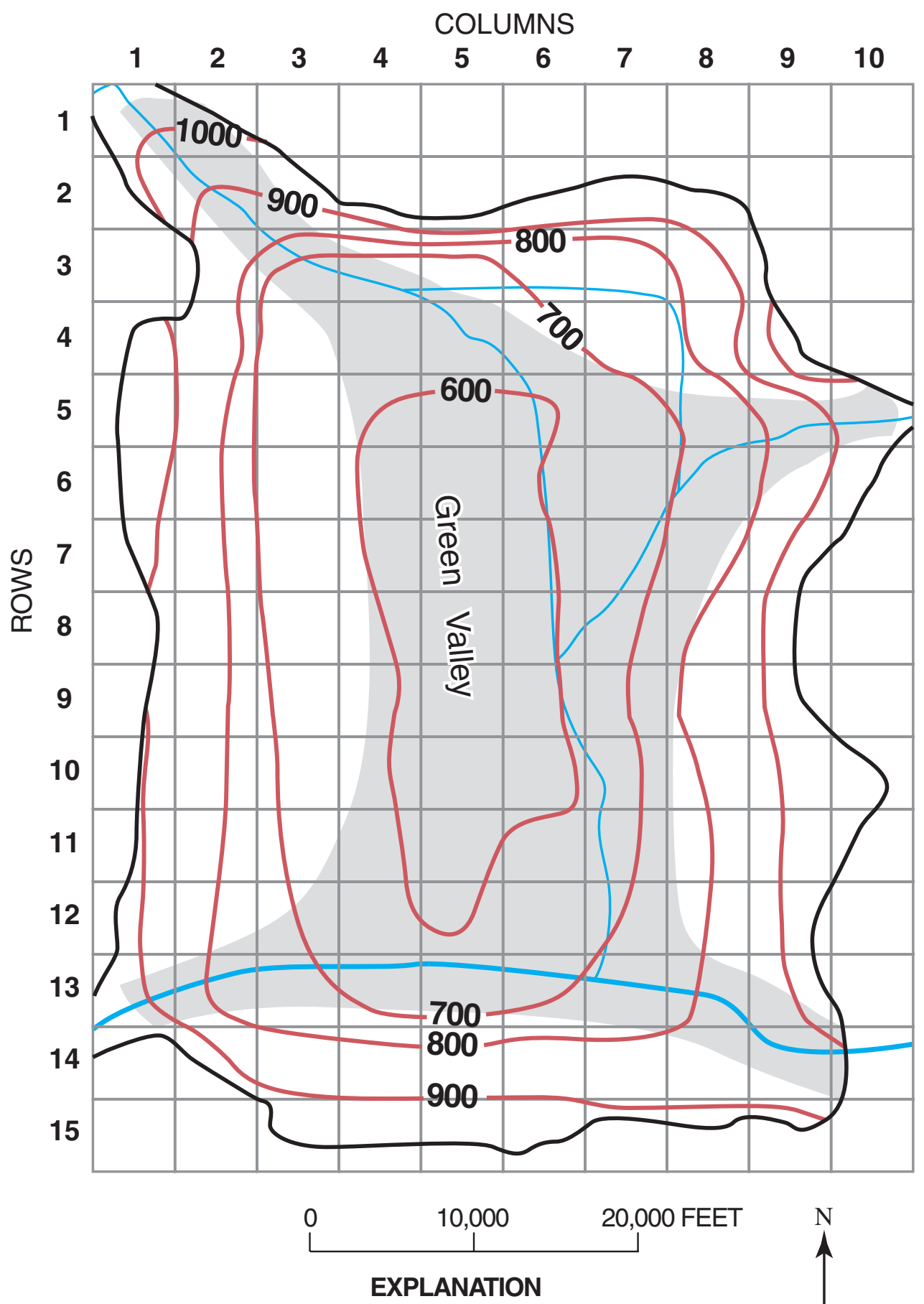

Hydraulic conductivity $=173$ feet per day; specific yield $=0.2$

Hydraulic conductivity = 35 feet per day; specific yield $=0.1$

$-900-$ Top of consolidated rocks contour-Shows elevation of top of consolidated rock. Contour interval is 100 feet

\section{Basin-fill boundary}

Figure 7. Model grid showing elevation of top of consolidated rocks beneath basin-fill aquifer and distribution of hydraulic conductivity and specific yield of the basin-fill aquifer used in test simulation 1. 

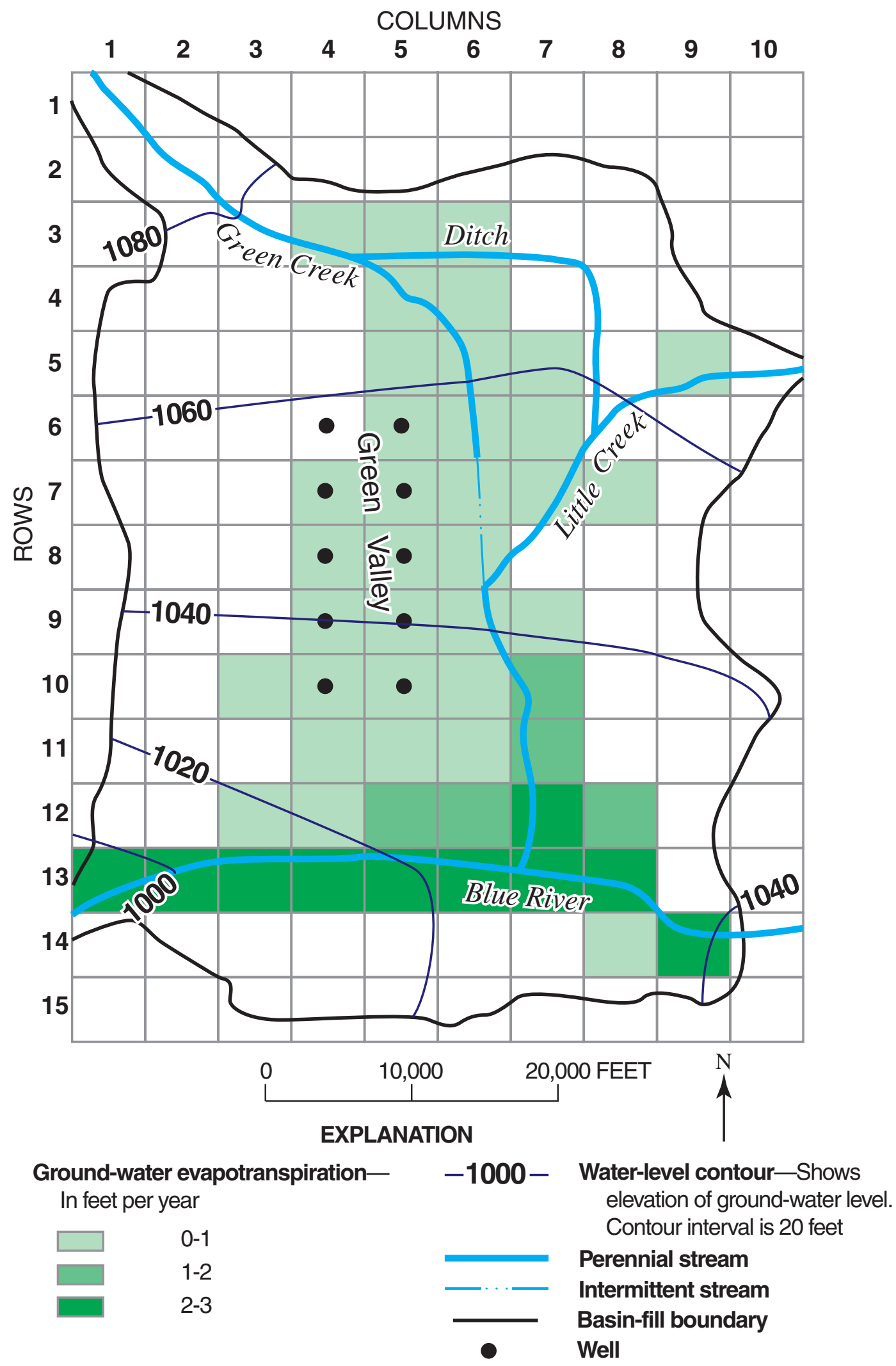

Figure 8. Model grid showing steady-state simulation of water-table contours, distribution of groundwater evapotranspiration, and locations of perennial-flow reaches used as initial conditions for the transient part of test simulation 1 . 
Table 1. Inflow rates, streambed properties, stream characteristics, and methods used for calculating stream depth and width in test simulation 1.

[Abbreviations: feet (ft); feet per second (ft/s); and cubic feet per second $\left(\mathrm{ft}^{3} / \mathrm{s}\right)$.]

\begin{tabular}{|c|c|c|c|c|c|c|c|c|c|c|}
\hline \multicolumn{2}{|c|}{ Stream $^{a}$} & \multirow{3}{*}{$\begin{array}{l}\text { Method } \\
(I C A L C)^{b}\end{array}$} & \multirow{3}{*}{$\begin{array}{c}\text { Inflow } \\
\text { rate } \\
\left(\mathrm{ft}^{3} / \mathrm{s}\right)\end{array}$} & \multirow{3}{*}{$\begin{array}{l}\text { Streambed } \\
\text { hydraulic } \\
\text { conductivity } \\
(\mathrm{ft} / \mathrm{s})\end{array}$} & \multirow{3}{*}{$\begin{array}{c}\text { Streambed } \\
\text { thickness } \\
\text { (ft) }\end{array}$} & \multirow{3}{*}{$\begin{array}{c}\text { Elevation } \\
\text { of } \\
\text { streambed } \\
\text { (ft) }\end{array}$} & \multirow{3}{*}{$\begin{array}{c}\text { Stream } \\
\text { depth } \\
\text { (ft) }\end{array}$} & \multirow{3}{*}{$\begin{array}{l}\text { Stream } \\
\text { width } \\
\text { (ft) }\end{array}$} & \multicolumn{2}{|c|}{$\begin{array}{l}\text { Manning's } \\
\text { roughness } \\
\text { coefficient }\end{array}$} \\
\hline \multirow{2}{*}{$\begin{array}{c}\text { Segment } \\
\text { number }\end{array}$} & \multirow{2}{*}{$\begin{array}{c}\text { First } \\
\text { and last } \\
\text { reach }\end{array}$} & & & & & & & & Channel & $\begin{array}{l}\text { Over } \\
\text { bank }\end{array}$ \\
\hline & & & & & & & & & \multicolumn{2}{|c|}{ (dimensionless) } \\
\hline \multirow[t]{2}{*}{1} & 1 & 4 & 25 & 0.00003 & 3 & 1095 & (b) & (b) & (c) & (c) \\
\hline & 4 & & & 0.00003 & 3 & 1075 & & & & \\
\hline \multirow[t]{2}{*}{2} & 1 & 1 & (d) & 0.00003 & 3 & 1075 & (b) & 12 & 0.030 & (c) \\
\hline & 5 & & & 0.00003 & 3 & 1050 & & 12 & & \\
\hline \multirow[t]{2}{*}{$3^{e}$} & 1 & 0 & 10 & 0.00003 & 2 & 1075 & 2 & 10 & (c) & (c) \\
\hline & 6 & & & 0.00003 & 2 & 1060 & 1 & 6 & & \\
\hline \multirow[t]{2}{*}{4} & 1 & 1 & 10 & 0.00003 & 3 & 1080 & (b) & 10 & 0.030 & (c) \\
\hline & 3 & & & 0.00003 & 3 & 1060 & & 10 & & \\
\hline \multirow[t]{2}{*}{5} & 1 & 3 & (d) & 0.00003 & 3 & 1060 & (b) & (b) & (c) & (c) \\
\hline & 4 & & & 0.00003 & 3 & 1045 & & & & \\
\hline \multirow[t]{2}{*}{6} & 1 & 1 & (d) & 0.00003 & 3 & 1045 & (b) & 12 & 0.030 & (c) \\
\hline & 5 & & & 0.00003 & 3 & 1025 & & 12 & & \\
\hline \multirow[t]{2}{*}{7} & 1 & 2 & 150 & 0.00006 & 3 & 1040 & (b) & (b) & 0.025 & 0.045 \\
\hline & 3 & & & 0.00006 & 3 & 1025 & & & & \\
\hline \multirow[t]{2}{*}{8} & 1 & 2 & (d) & 0.00006 & 3 & 1025 & (b) & (b) & 0.025 & 0.045 \\
\hline & 6 & & & 0.00006 & 3 & 990 & & & & \\
\hline
\end{tabular}

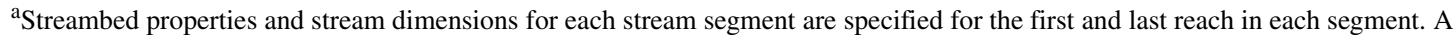
linear interpolation is used to determine the value at the midpoint of each reach.

${ }^{b}$ Method determines how stream depth and width are calculated for each reach in a segment. Stream depth and width are specified when ICALC is 0; stream depth is calculated from Manning's equation assuming a wide rectangular channel when ICALC is 1; stream depth and width are calculated from Manning's equation using an eight-point cross section when ICALC is 2; stream depth and width are calculated from a power function when ICALC is 3; and stream depth and width are calculated from a table of values when ICALC is 4 . See Appendix 1 or section "Computing Stream Depth."

cManning's roughness coefficient is not used for calculating stream depth or width when ICALC is 0,3 , or 4, and Manning's roughness coefficient for the overbank is not used when ICALC is 1 .

dinflow calculated from 1 or more tributary segments.

e Segment 3 is a diversion from segment 2 assuming all available flow to the rate specified is diverted.

Table 2. Relation of stream depth and width to streamflow used to compute stream depth and width for all reaches of stream segment 1 ( ICALC $=4$ ) in test simulation 1 .

[Abbreviations: feet (ft); and cubic feet per second $\left(\mathrm{ft}^{3} / \mathrm{s}\right)$.]

\begin{tabular}{lcccccccccccc}
\hline & \multirow{2}{*}{} & Units & \multicolumn{8}{c}{ Eleven values (NSTRPTS; see Appendix 1) were used to define the relation of stream depth and width to flow } \\
\cline { 2 - 11 } & & 1 & 2 & 3 & 4 & 5 & 6 & 7 & 8 & 9 & 10 \\
\hline Flow & $\mathrm{ft}^{3} / \mathrm{s}$ & 0.5 & 1.0 & 2.0 & 4.0 & 7.0 & 10.0 & 20.0 & 30.0 & 50.0 & 75.0 & 100.0 \\
Depth & $\mathrm{ft}$ & 0.25 & 0.4 & 0.55 & 0.7 & 0.8 & 0.9 & 1.1 & 1.25 & 1.4 & 1.7 & 1.8 \\
Width & $\mathrm{ft}$ & 3.0 & 3.5 & 4.2 & 5.3 & 7.0 & 8.5 & 12.0 & 14.0 & 17.0 & 20.0 & 22.0 \\
\hline
\end{tabular}



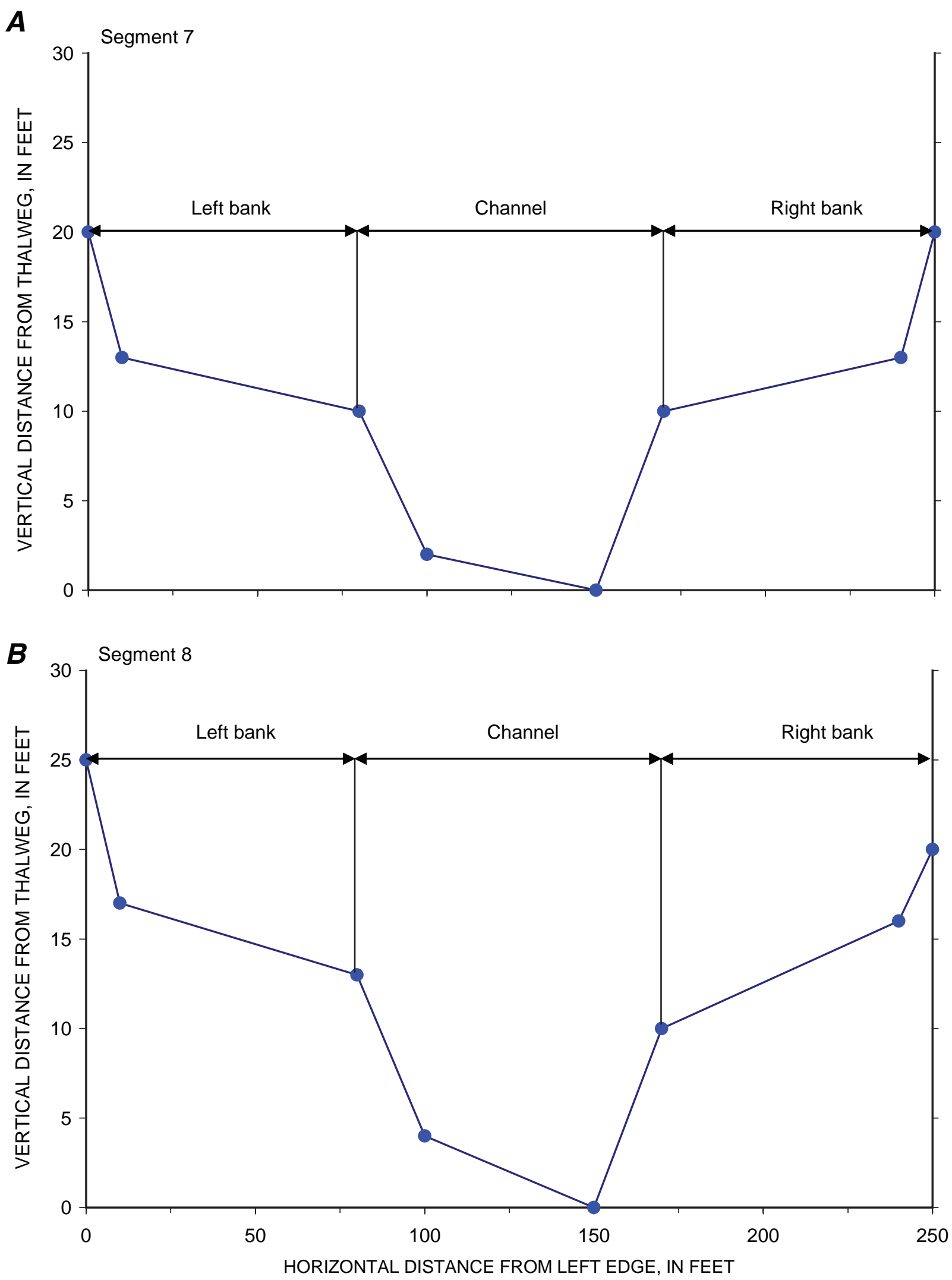

Figure 9. Stream cross sections used in computing stream depth for segments 7 and 8 in test simulation 1. 
Prior to the pumping of ground water, inflow into the aquifer was mostly from stream leakage, whereas outflow from the aquifer was mostly by evapotranspiration near the streams (table 3). Pumping at about twice the estimated ground-water inflow produced increased leakage from streams and decreased evapotranspiration (table 3). The distribution of flow in the streams and evapotranspiration after 50 years of pumping is shown in figure 10. Flow from the two perennial streams (Green Creek and Little Creek) entering Green Valley generally flowed through the valley to the Blue River prior to pumping (steadystate simulation; fig. 8). Much of the flow in Green Creek was diverted into a ditch that returned flow to Little Creek and a section of Green Creek was intermittent below the ditch and upstream from its confluence with Little Creek. After 50 years of withdrawals, pumping had captured all flows entering Green Valley from the two creeks because the perennial section of both streams receded closer to where the streams entered the valley (compare fig. 10 with fig. 8). The last reach on Green Creek (stream segment 6, reach 5) just upstream of the confluence with the Blue River has a small ground-water discharge, and the reach was perennial during the simulation. Groundwater levels and flow in streams recovered to pre-pumping conditions and ground-water flow in the valley had reached steady state by the end of the 50-year recovery period (no water was added or removed from storage; table 3 ).

Changes in flow, stream depth, and width during the transient simulation are illustrated in figure 11 for selected reaches that use different methods for computing stream depth and width. Flow out of the last reach in segment 1 (fig. 11A) decreased rapidly when pumping began, but the decrease slowed after only 3 years. The marked change in flow, stream depth, and width was caused by a decline in ground-water levels relative to the head in the stream for all cells corresponding to all the upstream reaches. After 3 years, cells upstream of the last reach began to decline below the streambed causing the slope of the decline in flow to decrease. Flow in the stream no longer changed after about 9 years of pumping because the groundwater level in cells corresponding to the all reaches in stream segment 1 had declined below the streambed and the leakage rates had become constant. This same pattern is shown for stream segment 5 (fig. 11B). Once withdrawals ceased, flow began to increase in the last reach of segment 5 after about 21 yrs after pumping had ceased and after about $19 \mathrm{yrs}$ in the last reach of segment 1 . The increase of flow in segments 1 and 5 during the recovery period was slower than the decrease in flow during the pumping period and largely was controlled by the gradual recovery of ground-water levels in areas distant from the pumping wells.

The last reach along the ditch (stream segment 3 ) was used to illustrate how the option of specifying a width and depth $($ ICALC $=0)$ works when flow in a channel ceases and when flow commences again (fig. 11C). Streambed depth and width were specified to decrease from 2 and $10 \mathrm{ft}$, respectively, at the beginning of the segment to 1 and $6 \mathrm{ft}$, respectively, at the end of the segment (table 1). Because the midpoint of the last reach is used to compute depth and width, the calculated values are slightly more (1.04 and $6.15 \mathrm{ft}$, respectively for depth and width) than those specified for the end of the segment. Stream width remained constant regardless of flow in the ditch (fig. $11 C$ ), whereas stream depth was constant as long as there was flow in the reach. Once flow in the reach ceased, the streambed elevation (depth $=0$ ) was used for comparing head differences between the stream and ground water. The slight lag between when flow out of the reach went to zero and when stream depth went to zero during the rapid decline (fig. $11 C$ ) was the result of all inflow into the reach leaking through the streambed. Inflow into the reach ceased during the following time step and consequently the entire reach became dry and stream depth became zero. The same lag occurred during the recovery period and was again caused by all inflow into the reach leaking through the streambed. Outflow from the last reach did not occur until inflow into the reach exceeded that which could leak through the streambed.

Flow in the last reach (reach 5) in segment 6 (fig. 11D) was used to illustrate what happens when there is no inflow from upstream reaches, but the ground-water level in the corresponding model cell is higher than the elevation of the streambed. In this example, the method for computing depth was Manning's equation assuming a wide rectangular channel ( ICALC $=1$ ). Although stream width remains constant throughout the simulation, stream depth is a function of flow. In this example, flow and stream depth decreased rapidly in the pumping (first stress) period and depth became zero after only 2 years, even though there was still a small quantity of outflow from the reach. The reason for stream depth being zero with minor outflow is that the only source of water to the reach is from ground-water leakage. When this occurs, stream depth at the midpoint of the reach is set to zero and the stream head at the midpoint is equal to the streambed elevation.

The last reach of segment 8 was used to illustrate changes in width and depth resulting from changes in streamflow using Manning's equation and an eight-point cross section (ICALC $=2)$. In the steady-state simulation, stream segment 8 was generally gaining, but became losing during the pumping period. Streamflow out of the reach, depth, and width decreased during the pumping period (fig. 11E) because inflow from upstream reaches declined and because leakage in the reach switched from flow out of the aquifer into the stream to flow from the stream into the aquifer. Although the water table declined in all cells corresponding to reaches in stream segments 7 and 8 , the water table did not decline below the streambed and consequently, streambed leakage did not become constant. Once pumping ceased, flow in the reach increased in a manner similar to how it decreased. The slight increase in flow after 70 years was due to an increase in flow from Green and Little Creeks to the north into Blue River. The response in segment 8 after pumping ceased in stress period 2 was much different than that for segments 1 and 5 (compare fig. $11 E$ with figs. $11 A$ and $11 B$ ) because ground-water levels did not decline below the bottom of the streambed beneath segment 8 whereas they did beneath segments 1 and 5 . 


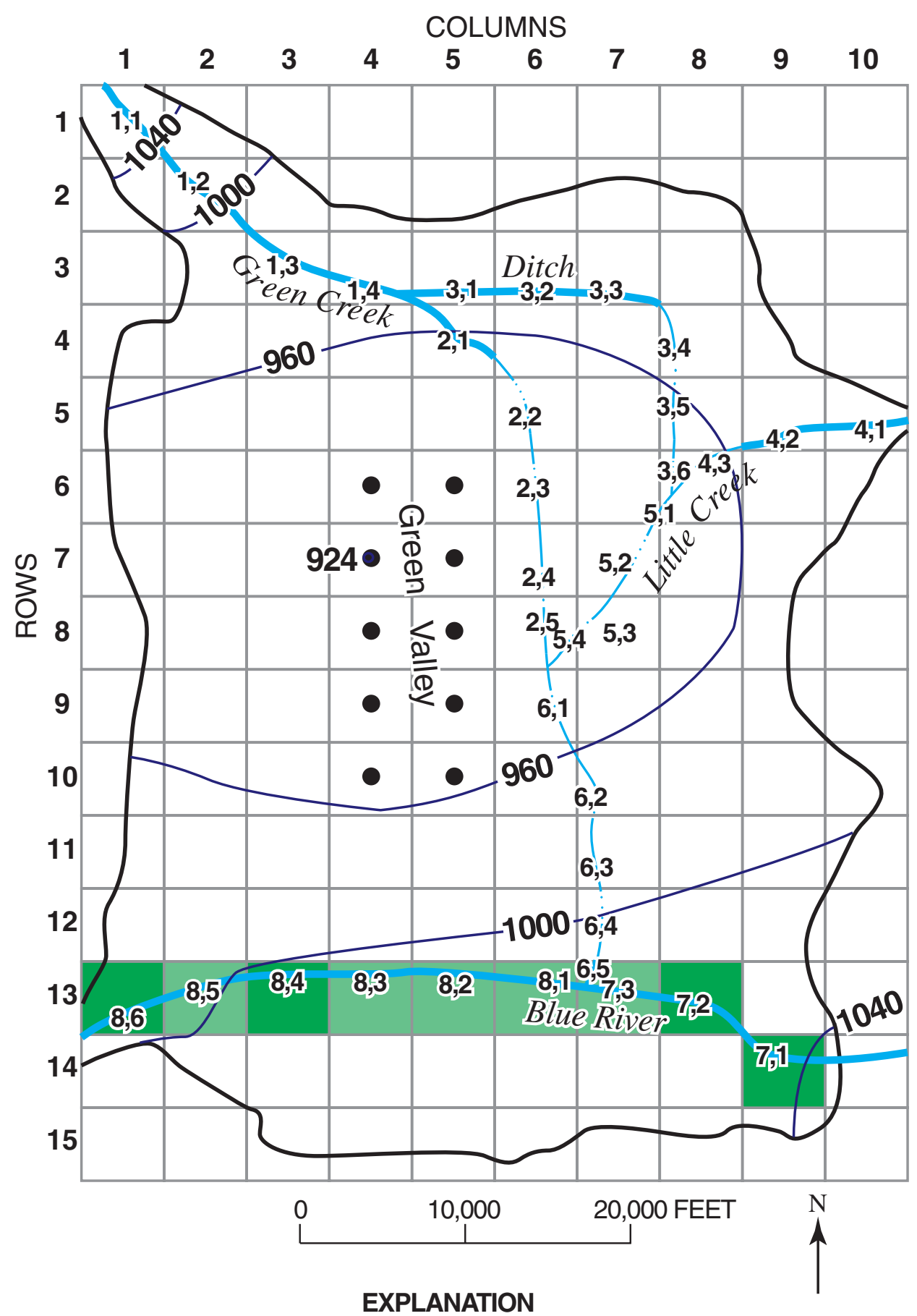

\section{Ground-water evapotranspiration-} In feet per year

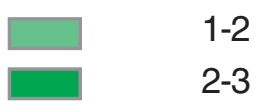

\section{8,4 Segment number and reach number}

$-1000-$ Water-level contour-Shows elevation of ground-water level. Contour interval is 40 feet

\section{Perennial stream}

Intermittent stream

Basin-fill boundary Well

Figure 10. Model grid showing simulated water-table contours, distribution of ground-water evapotranspiration, and locations of perennial-flow reaches after 50 years of pumping (end of first stress period) for test simulation 1. 
Table 3. Computed ground-water budgets for test simulation 1 .

[All rates are in cubic feet per second $\left(\mathrm{ft}^{3} / \mathrm{s}\right)$, rounded to $0.1 \mathrm{ft}^{3} / \mathrm{s}$ ]

\begin{tabular}{|c|c|c|c|c|c|c|c|}
\hline \multirow{2}{*}{ Water budget component } & \multirow{2}{*}{$\begin{array}{c}\begin{array}{c}\text { Steady } \\
\text { state }\end{array} \\
\text { Average } \\
\text { annual } \\
\text { rates }\end{array}$} & \multicolumn{3}{|c|}{$\begin{array}{l}\text { Stress period } 1 \\
\text { pumping }\end{array}$} & \multicolumn{3}{|c|}{$\begin{array}{l}\text { Stress period } 2 \\
\text { recovery }\end{array}$} \\
\hline & & $\begin{array}{l}\text { After } 1 \\
\text { year }\end{array}$ & $\begin{array}{l}\text { After } 10 \\
\text { years }\end{array}$ & $\begin{array}{l}\text { After } 50 \\
\text { years }\end{array}$ & $\begin{array}{l}\text { After } 51 \\
\text { years }\end{array}$ & $\begin{array}{l}\text { After } 60 \\
\text { years }\end{array}$ & $\begin{array}{c}\text { After } 100 \\
\text { years }\end{array}$ \\
\hline \multicolumn{8}{|l|}{ Inflow } \\
\hline Leakage from streams & 43.4 & 51.8 & 81.7 & 108.7 & 99.4 & 59.6 & 43.4 \\
\hline $\begin{array}{l}\text { Recharge along contact } \\
\text { with bedrock }\end{array}$ & 1.8 & 1.8 & 1.8 & 1.8 & 1.8 & 1.8 & 1.8 \\
\hline $\begin{array}{l}\text { Underflow beneath } \\
\text { streams entering basin }\end{array}$ & 0.2 & 0.2 & 0.2 & 0.2 & 0.2 & 0.2 & 0.2 \\
\hline Total Inflow & 45.4 & 53.8 & 83.7 & 110.7 & 101.4 & 61.6 & 45.4 \\
\hline \multicolumn{8}{|l|}{ Outflow } \\
\hline Wells & 0 & 100.0 & 100.0 & 100.0 & 0 & 0 & 0 \\
\hline Evapotranspiration & 35.9 & 20.8 & 15.6 & 14.2 & 14.7 & 17.8 & 35.9 \\
\hline Leakage to streams & 9.3 & 4.3 & .5 & .2 & .3 & 1.6 & 9.3 \\
\hline $\begin{array}{l}\text { Underflow beneath stream } \\
\text { exiting basin }\end{array}$ & .2 & .2 & .2 & .2 & .2 & .2 & .2 \\
\hline Total Outflow & 45.4 & 125.3 & 116.3 & 114.6 & 15.2 & 19.6 & 45.4 \\
\hline Removed from Storage & 0 & 71.5 & 32.6 & 3.9 & .1 & 0 & 0 \\
\hline Added to Storage & 0 & 0 & 0 & 0 & 86.3 & 42.0 & 0 \\
\hline
\end{tabular}

Streambed conductance varied with stream width for segments 1 and 5 (ICALC $=4$ and 3, respectively). Streambed conductance for these two segments decreased in proportion to decreased stream width (fig. 12A). Constant streambed conductance occurred when the ground-water level beneath each reach was below the streambed bottom and inflow into the reach remained constant. The streambed conductance for segment 5 was greater than for segment 1 because of a greater sensitivity of stream width to flow due to the parameters used for segment 5 , particularly at small stream depths. For segments 7 and 8 (fig. 12B), streambed conductance varied with the wetted perimeter that was computed from an eight-point cross section and Manning's equation ( ICALC $=2$ ). Streambed conductance for segment 7 decreased only about 1 percent during the pumping period ( 5.58 to $5.52 \mathrm{ft}^{2} / \mathrm{s}$ ) because streamflow only decreased $14 \mathrm{ft}^{3} / \mathrm{s}$ (140 to $126 \mathrm{ft}^{3} / \mathrm{s}$ ), whereas streambed conductance decreased nearly 22 percent ( 2.51 to about $1.97 \mathrm{ft}^{2} / \mathrm{s}$ ) in segment 8 in response to a decrease in flow of $64 \mathrm{ft}^{3} / \mathrm{s}(150$ to $86 \mathrm{ft}^{3} / \mathrm{s}$ ). 


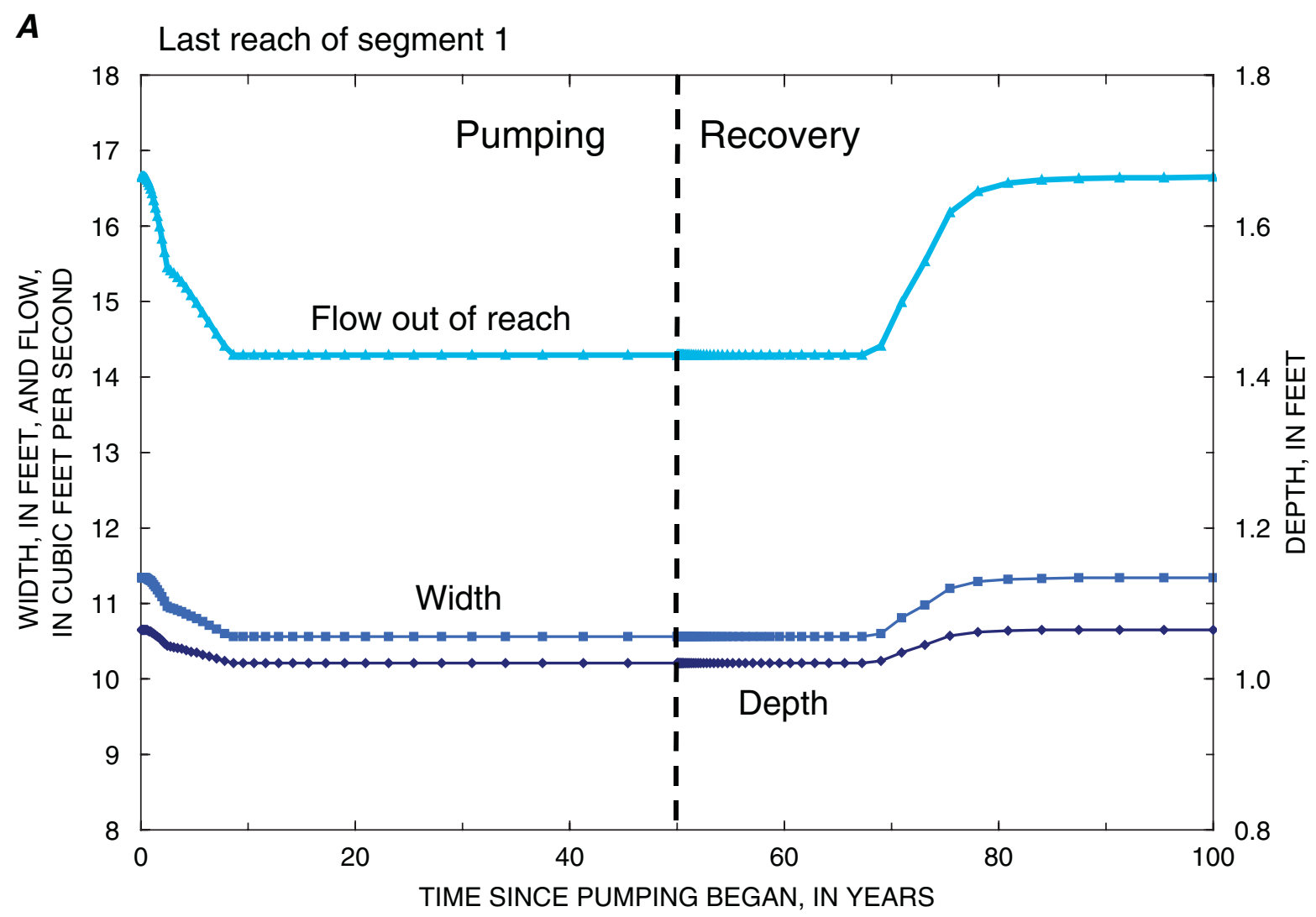

B

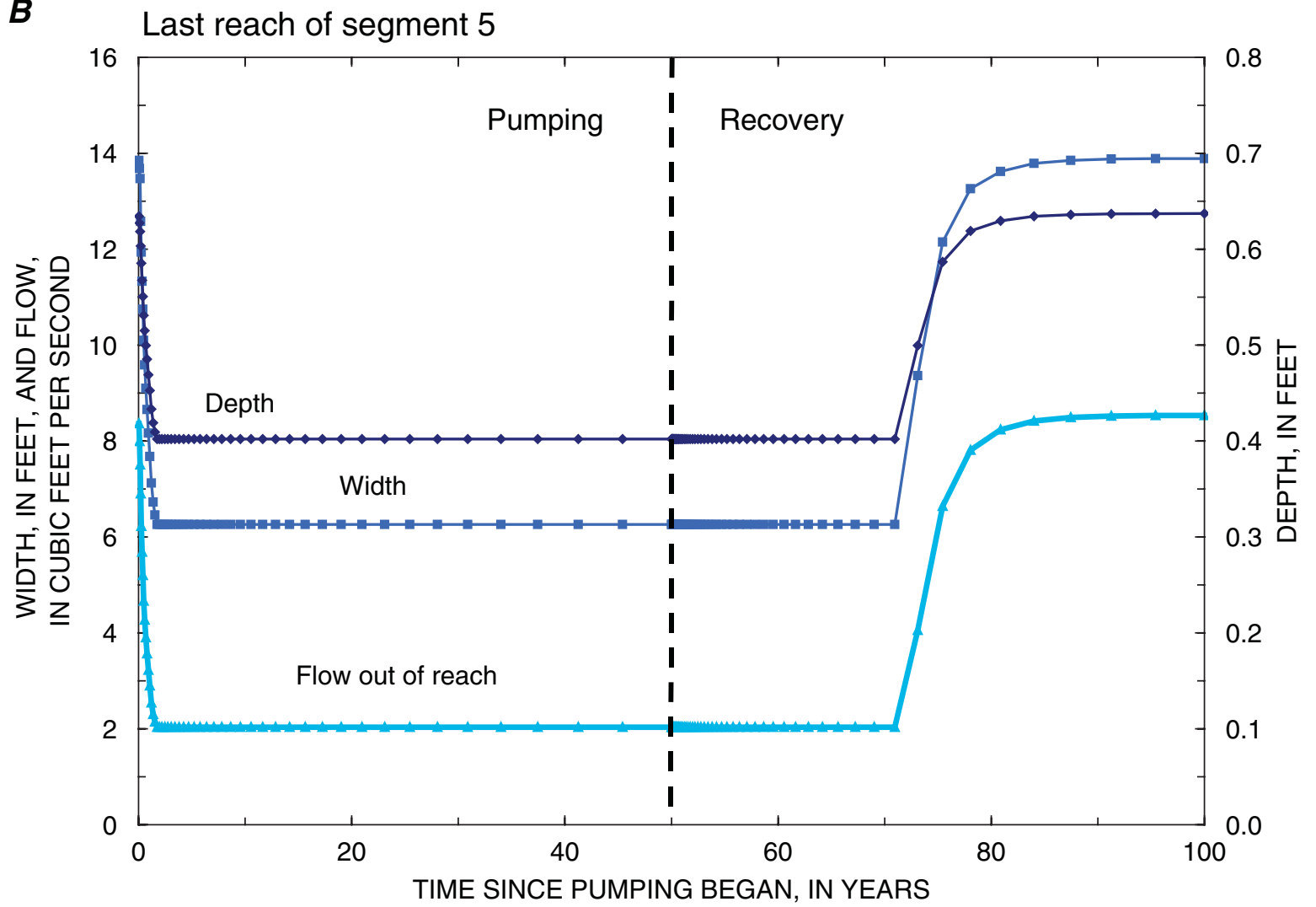

Figure 11. Changes in stream depth, width, and flow in last reach of selected stream segments during a 50-year pumping period in test simulation 1 followed by a 50 -year recovery period. 

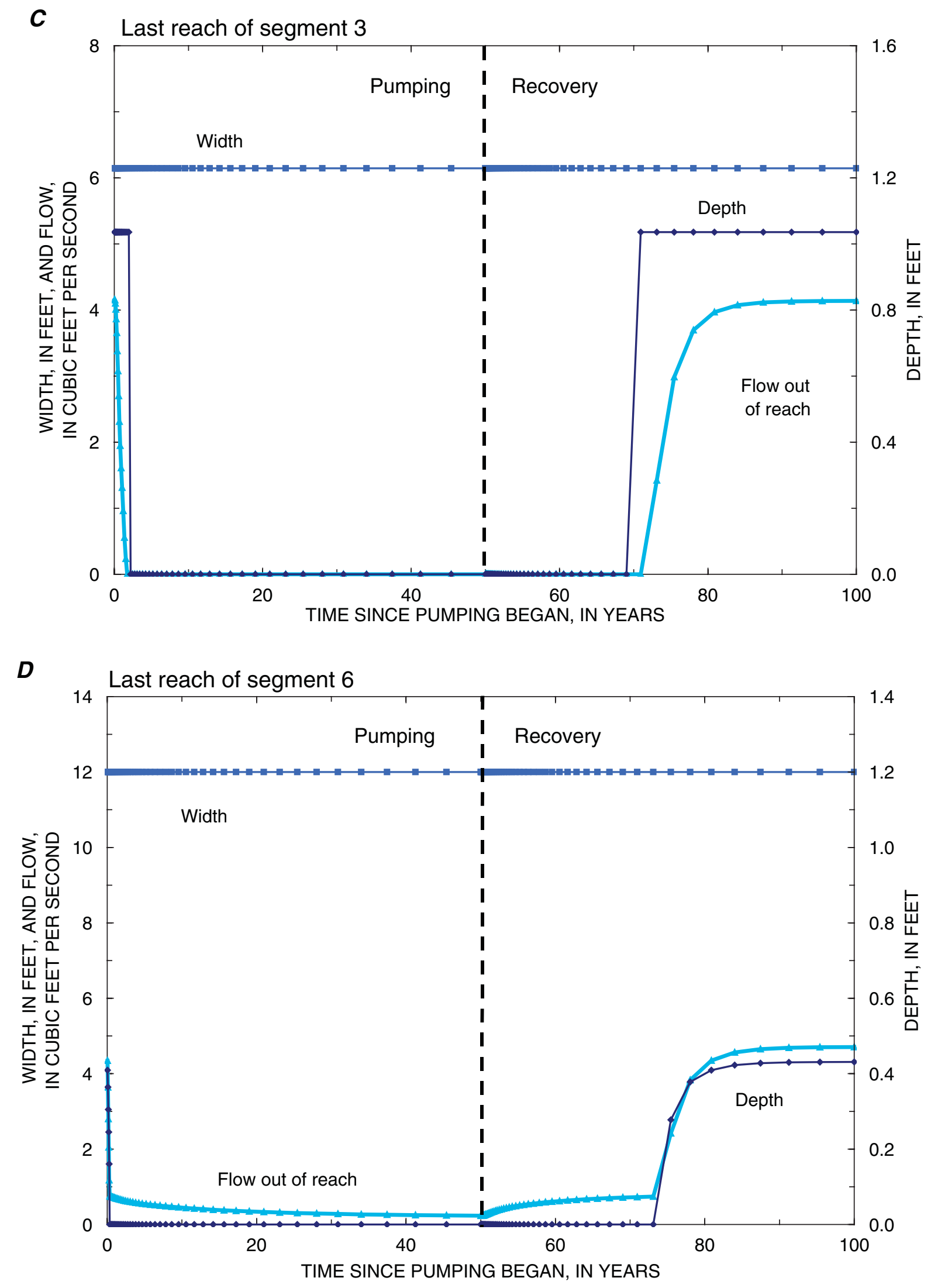

Figure 11. Continued 
E

Last reach of segment 8

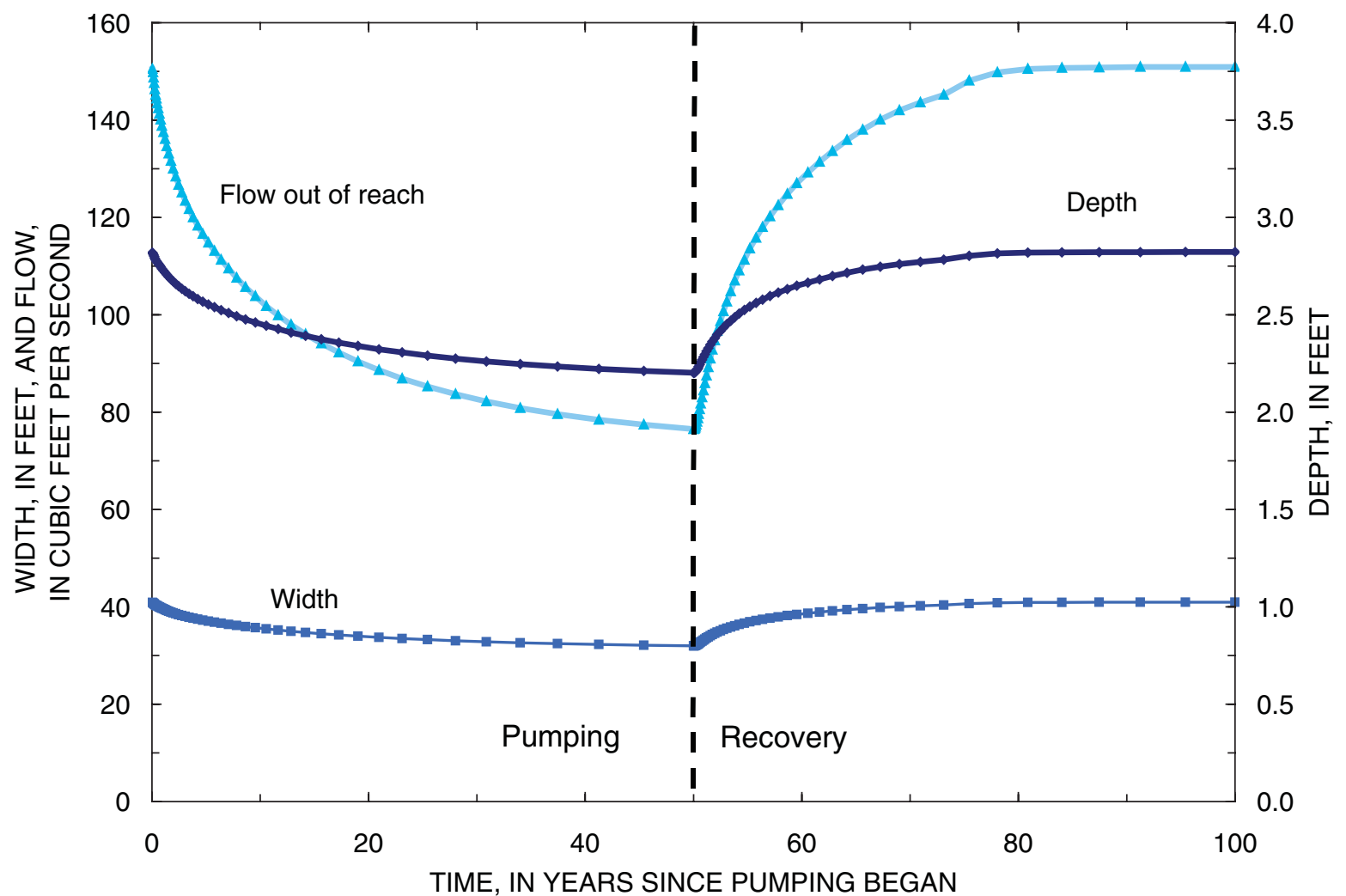

Figure 11. Continued

\section{Test 2: Stream-Lake Interaction with Solute Transport}

A hypothetical (but realistic) problem was designed to test and illustrate the integration of the SFR1 Package with the LAK3 Package and the GWT Process. The characteristics of the test case are inspired by a contamination problem in a sand and gravel aquifer in Cape Cod, Massachusetts, as documented in detail by LeBlanc (1984). At this site, effluent from a sewage treatment plant recharges the aquifer and is the source of a plume of contaminated water. One edge of the plume appears to discharge into the western edge of a small lake connected to the aquifer. The test case is a highly simplified and idealized abstraction of the field conditions at this site, and a purely hypothetical stream network was added to the system to facilitate testing and evaluating the SFR1 Package. Although parameter values and boundary conditions were selected on the basis of reported field conditions, this example analysis is not intended to yield an accurate simulation of the actual flow field or observed plume in Cape Cod. The boundary conditions for this test problem differ slightly from those used in a similar test problem described by Merritt and Konikow (2000) in that streams are included in the model simulation of flow and transport.
The aquifer is moderately permeable and is assumed to have homogeneous properties and uniform thickness (table 4). The aquifer was discretized into 8 layers (each $15 \mathrm{ft}$ thick), 36 rows (at equal spacing of $405.7 \mathrm{ft}$ ), and 23 columns (at equal spacing of $403.7 \mathrm{ft}$ ). A steady-state head distribution was assumed representative of the average flow field. Uniform recharge was applied at a rate of $21 \mathrm{in}$./yr to the top layer (layer 1) of the model. Two lakes are located within the model domain. The eastern lake (lake 1) is connected to a stream. Both lakes only occupy cells within the first model layer (at locations shown in fig. 13); this enables horizontal leakage between the lakes and adjacent active aquifer cells in layer 1 and vertical leakage between the lakes and underlying active aquifer cells in layer 2. Streams are connected to model layer 1.

The boundary conditions are illustrated in figure 13 and were designed to produce flow that is generally from north to south. For the numerical model, constant-head conditions were specified along the northern and southern edges of the model domain, and no-flow boundaries were set along the east and west edges of the grid. Because lake cells and aquifer cells cannot occupy the same space, lake cells in layer 1 (fig. 13) are inactive aquifer cells in the model grid. The constant-head boundaries were placed in all 8 layers at the map locations shown in figure 13, with two exceptions. The first exception is 
$\boldsymbol{A}$

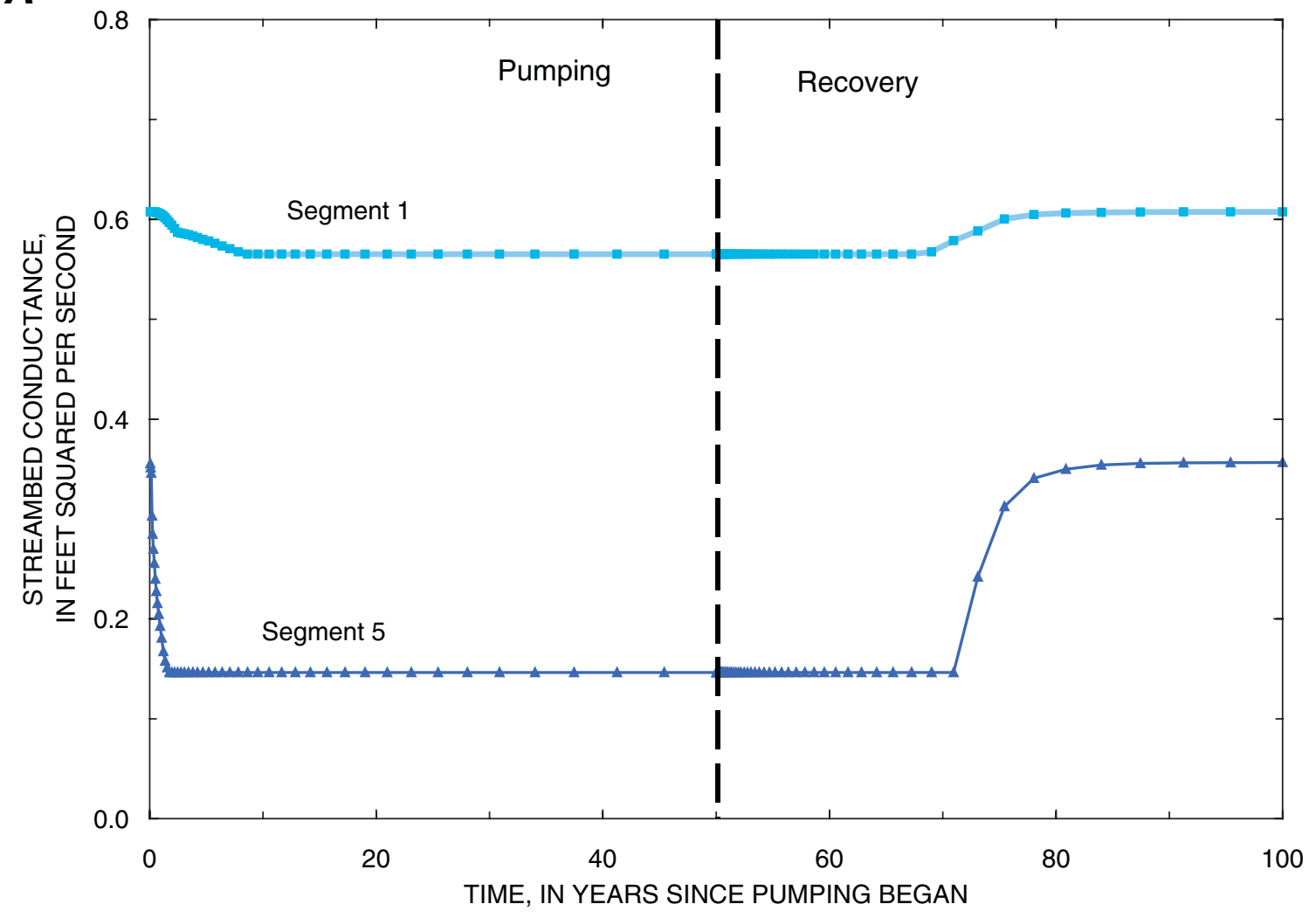

$\boldsymbol{B}$

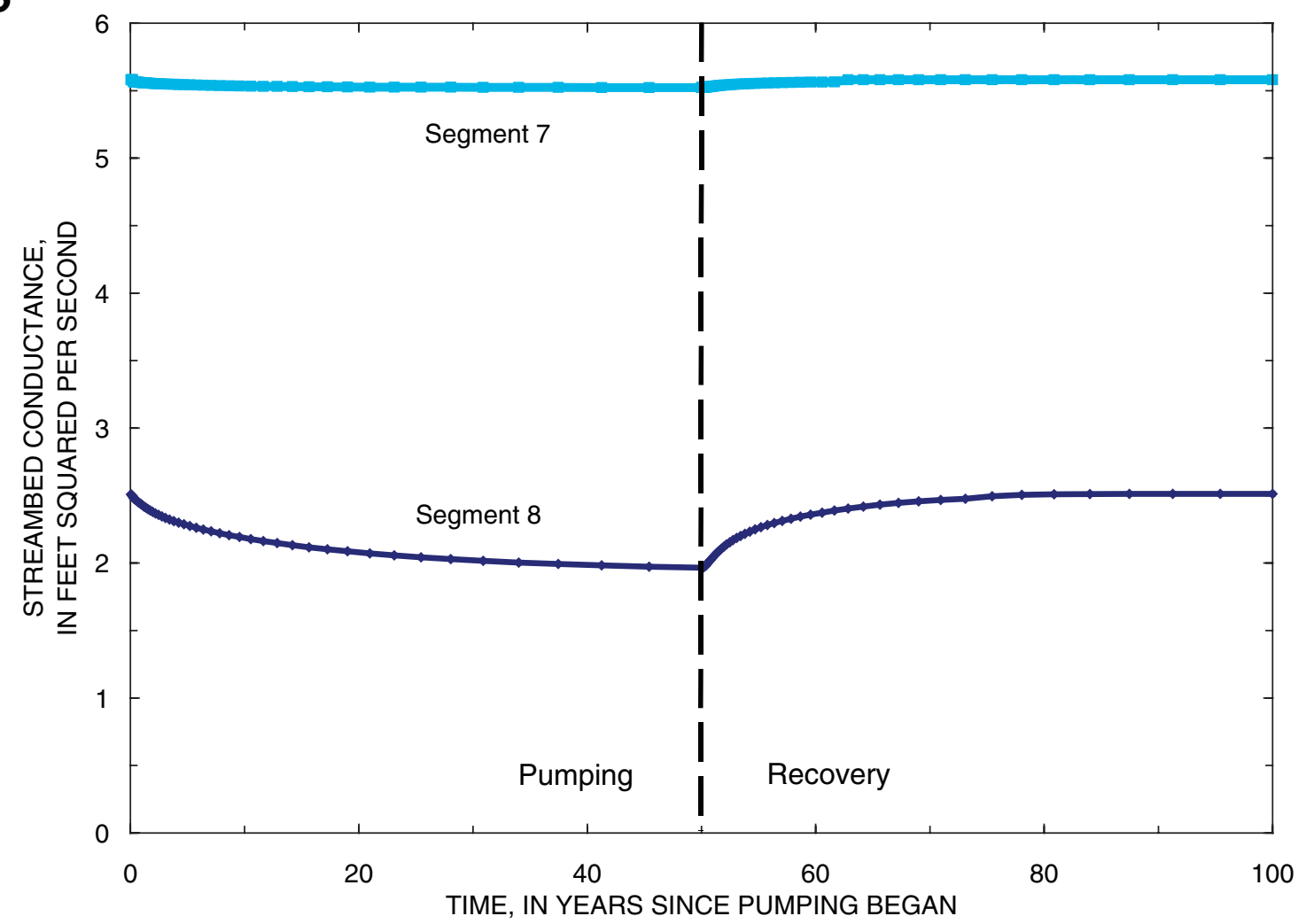

Figure 12. Changes in streambed conductance in last reach of selected stream segments during a 50-year pumping period in test simulation 1 followed by a 50 -year recovery period. 
related to the last downstream reach of stream segment 4 . The grid cell in which the reach is located and the cell underlying it in layer 2 are both specified as active aquifer cells rather than as constant-head cells because a constant head in that cell with the stream reach would have set the gradient across the streambed. The second exception is related to the contaminant source (from treated sewage effluent), which is only introduced into the upper two model layers (that is, to a total of 8 cells). The four cells in layer 3 that underlie the contaminant source are specified as active aquifer cells rather than as constant-head cells to simulate transport beneath the source. Constant-head elevations were specified as $50.0 \mathrm{ft}$ along the north boundary, except at the 4 cells in each of the upper two model layers that represent inflow from the contaminant source, where the fixed heads were $50.15 \mathrm{ft}$ in the two middle cells and $50.10 \mathrm{ft}$ in the two outer cells. The constant-head elevations were set to $28.0 \mathrm{ft}$ along the south boundary.
The stream network consists of four segments and 38 reaches. The stream depths are calculated using Manning's equation assuming a wide rectangular channel ( ICALC $=1$ ). For all stream reaches, the channel width was assumed constant at $5.0 \mathrm{ft}$ and the roughness coefficient for the channel was 0.03 . Inflows to segments 1 and 3 were specified (86,400 and 8,640 $\mathrm{ft}^{3} / \mathrm{d}$, respectively). The inflow to stream segment 2 was equal to the outflow from lake 1 , and it was calculated using Manning's equation assuming a wide rectangular channel (consistent with ICALC =1) with a depth based on the difference between the calculated lake stage and the elevation of the top of the streambed (see Merritt and Konikow, 2000, p. 11). The inflow to segment 4 is calculated as the sum of outflows from tributary segments 2 and 3 .

Moderate amounts of data from the Cape Cod study area are available for boron concentrations in the observed plume and in the sewage effluent, so boron was selected as the simulated solute for this test case. Variables related to the calculation

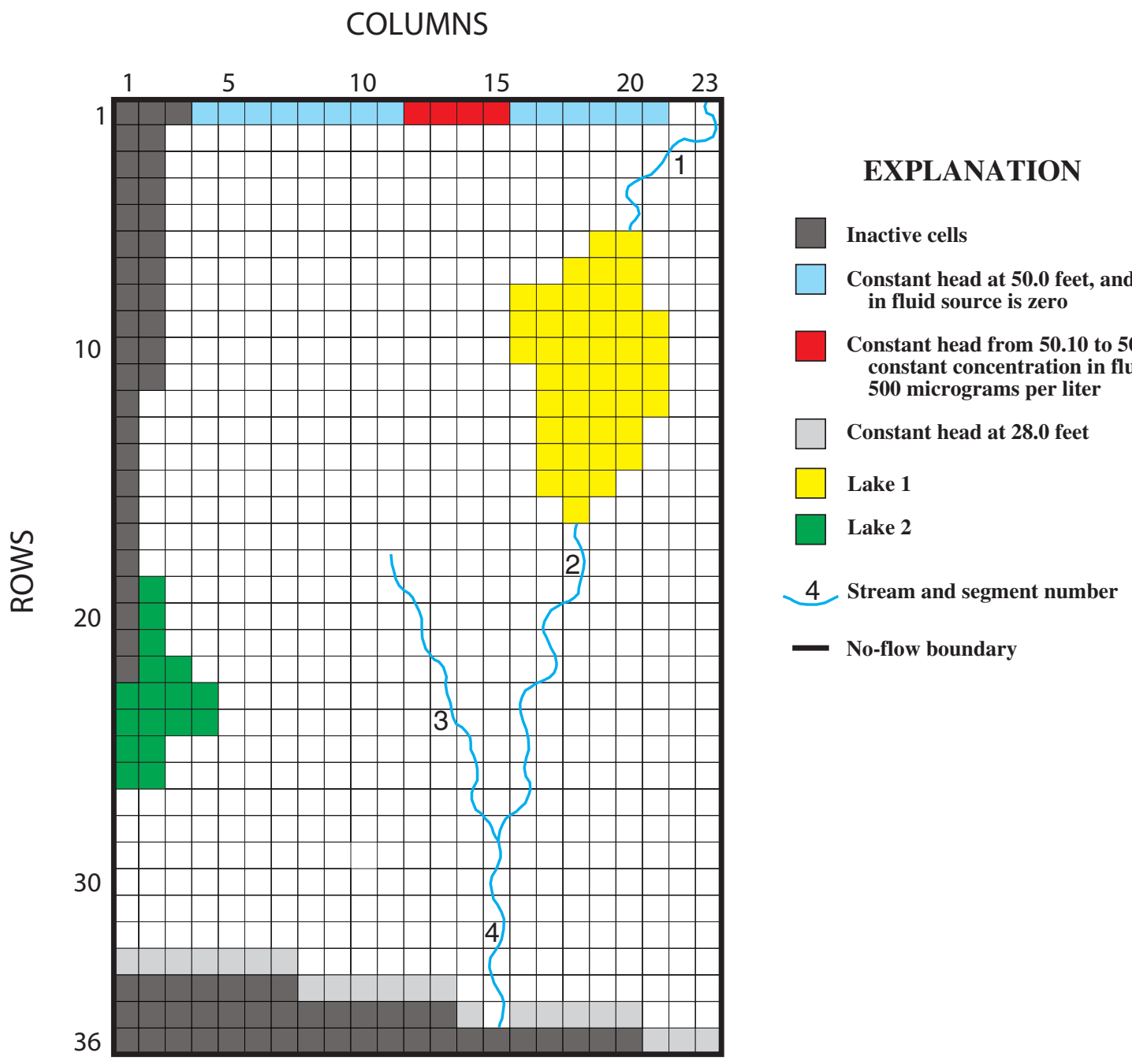

Figure 13. Finite-difference model grid of layer 1, boundary conditions, and locations of lakes and streams used in test simulation 2. 
Table 4. Hydraulic and transport properties used in test simulation 2.

\begin{tabular}{lc}
\multicolumn{1}{c}{ Variable } & Value \\
\hline Horizontal hydraulic conductivity (feet per day) & 250 \\
Vertical hydraulic conductivity (feet per day) & 125 \\
Storage coefficient (cubic foot of water per cubic foot of aquifer) & 0 \\
Aquifer thickness (feet) & 120 \\
Porosity (cubic foot of voids per cubic foot of aquifer) & 0.30 \\
Recharge rate (feet per day) & $4.79 \times 10^{-3}$ \\
Lakebed leakance (inverse day) & 1 \\
Streambed hydraulic conductivity (feet per day) & 100 \\
Streambed thickness (feet) & 1 \\
Longitudinal dispersivity (feet) & 20 \\
Horizontal transverse dispersivity (feet) & 2 \\
Vertical transverse dispersivity (feet) & .2 \\
Diffusion coefficient (feet squared per day) & 0 \\
Initial concentration (micrograms per liter) & 0 \\
Source concentration (micrograms per liter) & 500 \\
\hline
\end{tabular}

of solute concentration are listed in table 4. For the purposes of this test, boron was assumed nonreactive. Molecular diffusion in the aquifer was assumed a negligible contributor to solute spreading at the scale of the field problem, so that hydrodynamic dispersion was related solely to mechanical dispersion, which was computed in MODFLOW-GWT as a function of the specified dispersivity of the medium and the velocity of the flow field. The initial boron concentrations in the aquifer and in the lakes were assumed to be zero, and the sewage effluent concentration was assumed to be $500 \mu \mathrm{g} / \mathrm{L}$. The source concentration in recharge was assumed to be zero and the concentration in specified inflow to stream segments 1 and 3 was also zero. The strongly implicit procedure (SIP) was used to solve the flow equation. The solute-transport model was run for a stress period of 25 years.

Selected parts of the input and output files for this test case are shown in Appendix 3. The test problem required 394 iterations in SIP to converge to a solution. The simulation required 6 minutes 50 seconds of CPU time on a personal computer having a $2 \mathrm{GHz}$ Pentium 4 processor and $512 \mathrm{MB}$ of RAM. The calculated steady-state head distributions in layers 1 and 2 are shown in figure 14. The heads in layers 3 through 8 are almost identical to the heads shown for layer 2 (fig. 14B). As expected, the flow is generally from north to south and predominantly horizontal. Because of recharge at the water table, however, there is a slight vertically downward flow in most areas. The lakes and streams exert a strong influence on the location and magnitude of vertical flow, as shown in figure 15 . In layer 2 , the good hydraulic connection with the lakebed results in an almost flat horizontal hydraulic gradient in head beneath the lakes (fig. 14B). Ground water discharges into the lakes in the north- ern (upgradient) parts of both lakes, and the lakes lose water (and recharge the aquifer) in the southern (downgradient) parts of the lakes. The model calculated steady-state stage in lake 1 was $45.0 \mathrm{ft}$ and in lake 2 was $37.1 \mathrm{ft}$. Stream segment 1 was mostly a gaining stream (leakage across streambed was from ground water), and stream segment 2 was losing such that outflow from the last reach in segment 2 was only half of the inflow from lake 1. Stream segment 3 was mostly gaining and outflow from this segment was only from ground-water leakage. Lastly, stream segment 4 was a losing stream and leakage was from the stream to ground water in every reach. Flow into and out of each stream segment and reach is documented in the main MODFLOW listing in Appendix 3. Gaining and losing segments can also be inferred from hydraulic head contours near each stream segment (fig. 14).

MODFLOW-GWT required 1,229 time increments to solve the transport equation for a 25 -year stress period. The solution used the explicit dispersion solver, 27 particles per cell, and a value of CELDIS $=0.50$ (CELDIS is defined in Konikow and others, 1996). The calculated concentration in lake 1 and in the outflow from the last reach in stream segments 2,3 , and 4 during the 25-year simulation period are shown in figure 16 . (This plot was constructed from the output files from the Gage Package after converting the output units of time in days to time in years.) Note that because stream segment 2 lost flow to ground water in all reaches and its only source was inflow from lake 1 , solute concentration in the outflow from the last reach in stream segment 2 was equal to the concentration in the discharge from lake 1 (fig. 16). The small amount of noise in the calculated concentrations is common in numerical solutions to the solute-transport equation based on the method of 


\section{A. LAYER 1}

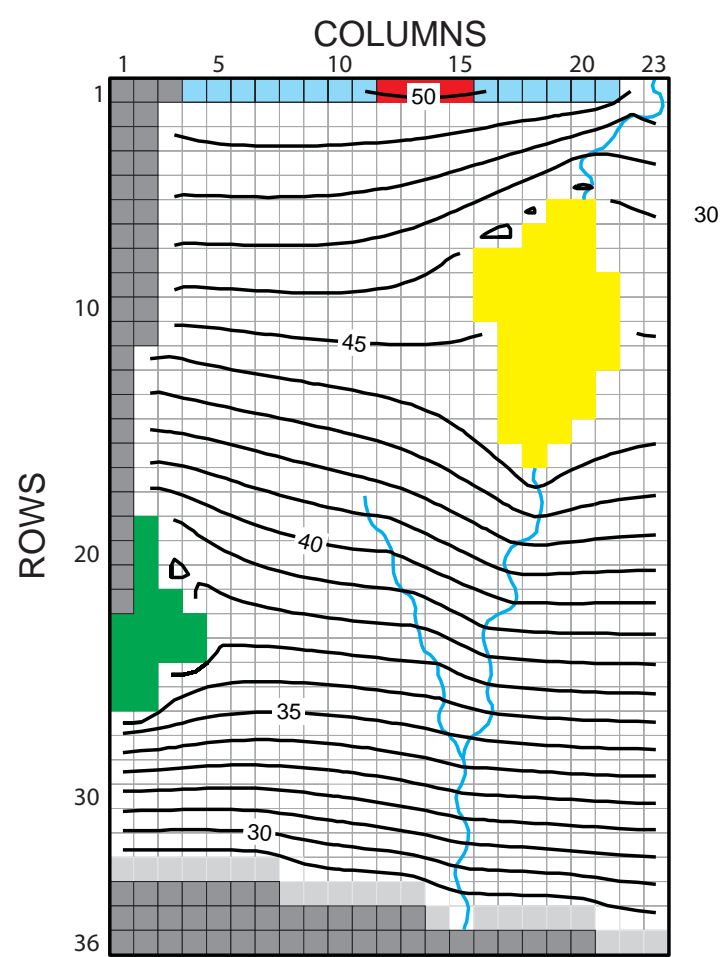

\section{B. LAYER 2}

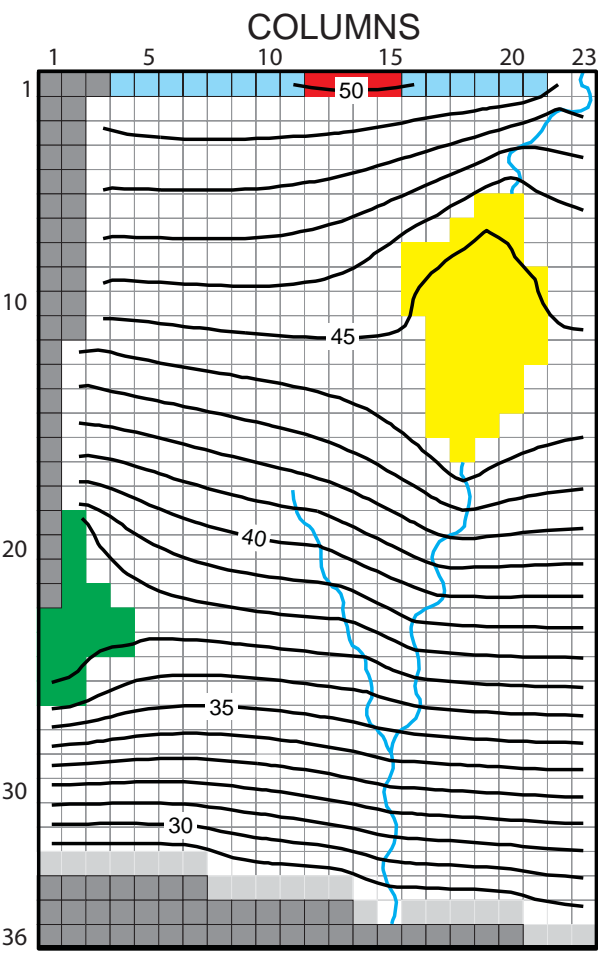

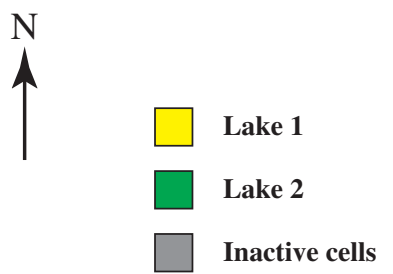

EXPLANATION

Constant head at 50.0 feet, and concentration in fluid source is zero

Constant head from $\mathbf{5 0 . 1 0}$ to $\mathbf{5 0 . 1 5}$ feet, and constant concentration in fluid source of 500 micrograms per liter

Constant head at 28 feet

Line of equal hydraulic head, in feet-Contour interval 1 foot Stream

Figure 14. Contours of simulated steady-state heads in $(A)$ layer 1 and $(B)$ layer 2 for test simulation 2.

characteristics, and reflects a slight loss of precision rather than a loss of accuracy. The leading edge of the plume reaches the upstream edge of lake 1 after about 4 years, at which time the concentration in the lake begins to increase rapidly. After about 22 years, the part of the plume close to the source and near the lake has stabilized and the concentration in the lake reaches an equilibrium concentration of $37.4 \mu \mathrm{g} / \mathrm{L}$.

As the lake concentration increases, it in turn acts as a source of contamination to the aquifer in the areas where the lake is a source of water to the aquifer. Although the lake significantly dilutes the contaminants that enter it from the aquifer, the lake and the stream segments downstream from it in effect provide a short circuit for the relatively fast transmission of low levels of the contaminant. This is evident in figure 17, which shows the computed solute distributions in layers 1,3 , and 5 after 25 years. The low-concentration part of the plume emanating from the downgradient side of lake 1 has advanced farther, and is wider, than the main plume that emanated directly from the source at the north edge of the model. The influence of ground-water discharge to stream segment 3 is most apparent in the concentration pattern shown in figure $17 \mathrm{~A}$ (that is, the 25 $\mu \mathrm{g} / \mathrm{L}$ contour). Comparison of concentration levels at different depths in the system indicates that in the southern part of the area, concentrations generally increase with depth. In contrast, in the northern part downgradient from the source, the highest concentrations occur in layer 3 . These various patterns result from the dilution effect of recharge of uncontaminated water at the water table coupled with the consequent downward component of flow, which causes the solute to move slowly downward as it migrates to the south. 


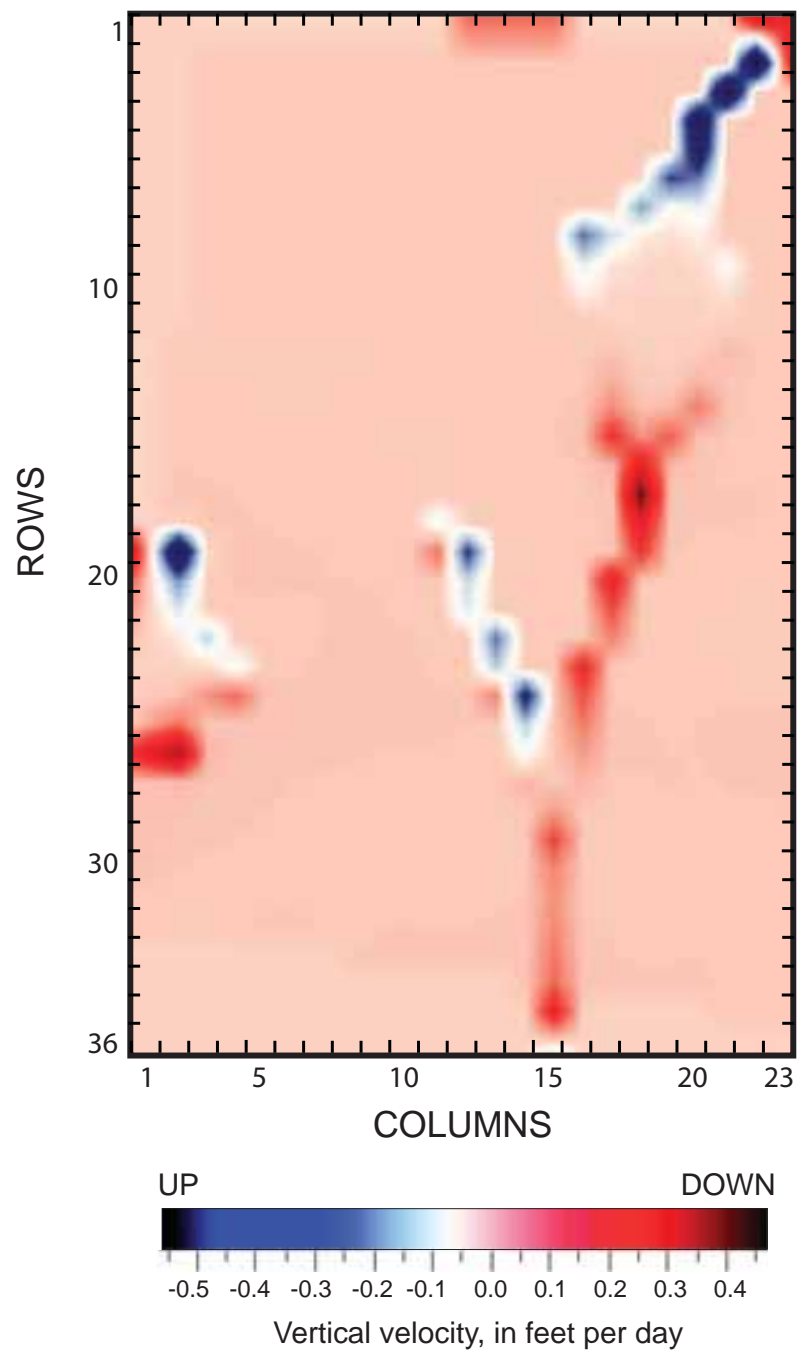

Figure 15. Distribution of vertical flow velocity between layers 1 and 2 for steady-state conditions in test simulation 2.

\section{Implementation of SFR1 Package with MODFLOW-2000}

The SFR1 Package consists of ten subroutines that are used for the Ground-Water Flow (GWF) Process of MODFLOW-2000 (Harbaugh and others, 2000), three subroutines that are used to read and write parameters and nonparameters, and one subroutine that checks for incompatibilities with the Sensitivity Process in MODFLOW-2000. A description of how the SFR1 Package is connected to the Ground-Water Transport (GWT) Process of MODFLOWGWT is given in the next section. A generalized flow chart of the main components of the SFR1 Package for the GWF Process is shown in figure 18. Each subroutine or module is identified first by GWF1 (Ground-Water Flow Process), followed by SFR1 (version 1 of the SFR1 Package), and then followed by the division of procedures used in MODFLOW2000. For example, GWF1SFR1ALP is the module that allocates space for the SFR1 Package. The standard modules that are called from the main program are: GWF1SFR1DF, GWF1SFR1ALP, GWF1SFR1RPP, GWF1SFR1RPS, GWF1SFR1FM, and GWF1SFR1BD. Four additional subroutines (modules) are used to compute stream depth given streamflow and streamflow given stream (or lake) depth within the formulate module (GWF1SFR1FM) and the budget module (GWF1SFR1BD). The module GWF1SFR1DPTH is used to compute depth given streamflow and the module GWF1SFR1FLW is used to compute streamflow given depth from Manning's equation and an eight-point cross section. The module GWF1SFR1TBD is used to compute depth given streamflow and the module GWF1SFR1TBF is used to compute streamflow given depth from a table of values that relate streamflow to stream depth and width.

The MAIN program of MODFLOW-2000 has been further modified to designate "SFR" in position 44 in CUNIT. Whenever "SFR" is used at the beginning of a line in the NAME file, the program will use the specified unit number and file name to obtain information for the SFR1 Package and will execute MODFLOW-2000 using the SFR1 Package.

Output from the SFR1 Package can be printed: (1) to the main listing file; (2) to a separate listing file when requested in the SFR1 input; and (or) (3) to separate files for each specified stream reach that provides a time series of selected information using the Gage Package. Input instructions for the Gage Package are provided at the end of the input instructions for the SFR1 Package in Appendix 1. Six options are available to print time series for each specified reach. The first option, OUTTYPE $=0$, will print stream stage at the midpoint 


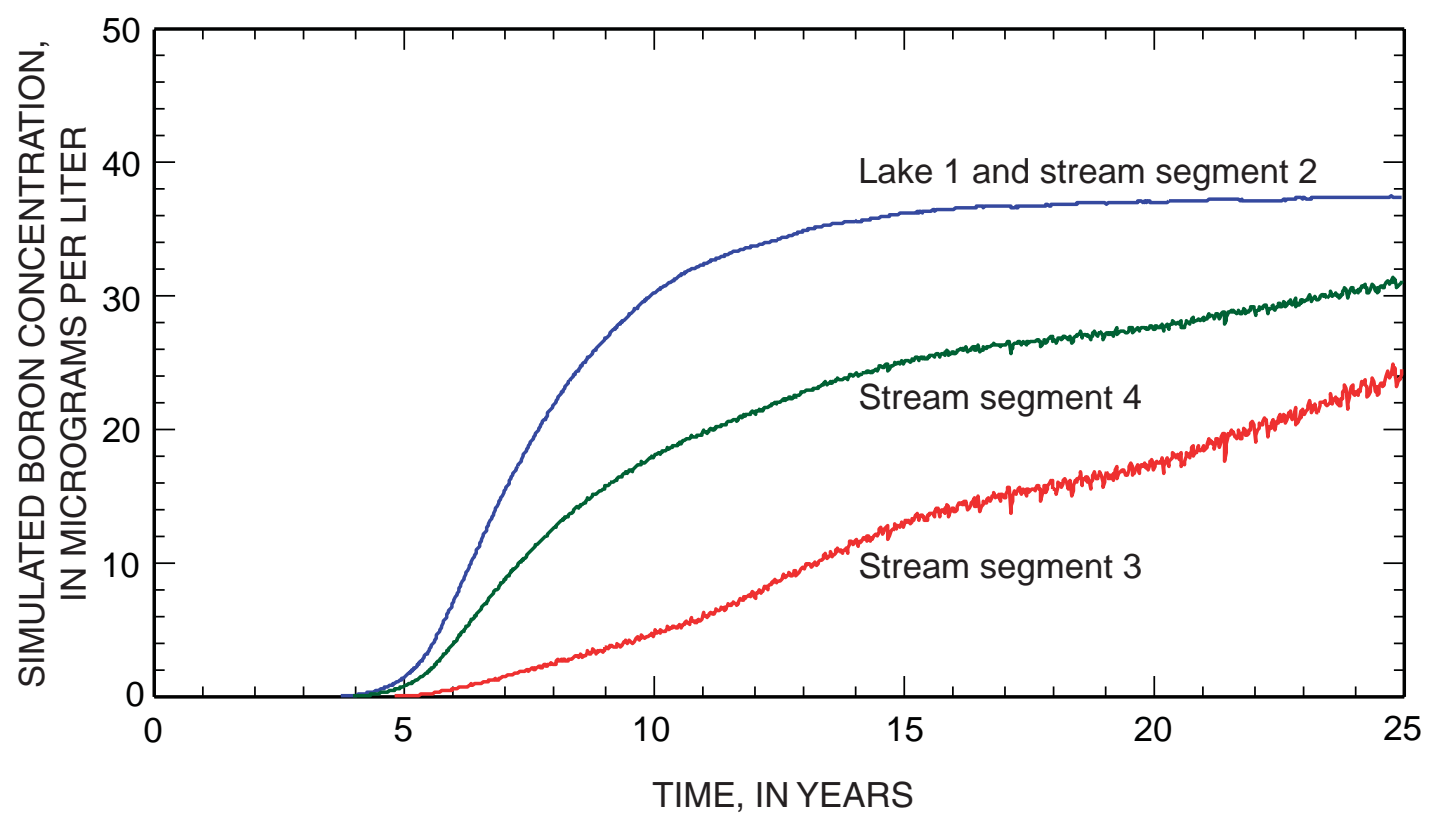

Figure 16. Changes in simulated boron concentrations in lake 1 and at the end of stream segments 2,3, and 4 for steady ground-water flow and transient solute transport in test simulation 2.

of a reach, and streamflow out and solute concentration at the end of the selected reach. The option, OUTTYPE $=1$, adds stream depth, width, and streamflow at the midpoint of a selected reach to the variables in OUTTYPE $=0$. The option, OUTTYPE $=2$, adds streambed conductance, head difference between stream and aquifer, and gradient across the streambed to the variables in OUTTYPE $=0$. The option, OUTTYPE $=3$, adds solute load at the end of a selected reach to the variables in OUTTYPE $=0$. The option, OUTTYPE $=4$, prints the times series of all the variables listed in OUTTYPE $=0-3$. The last option, OUTTYPE $=5$, is for the first reach of a diversion and will print a time series of stream stage, flow diverted, maximum assigned diversion rate, flow at end of upstream segment prior to diversion, solute concentration, and solute load at the beginning of the reach. The Gage Package also can be used to print time series data for a specified lake, and was used for the time series graphs shown on figures 11 and 12 as well as the time series shown on figure 16.

The SFR1 Package has been programmed to apply leakage from a stream reach to a designated underlying cell. If the water level in the underlying cell becomes less than the bottom elevation of the cell, it becomes inactive. When this happens, SFR1 will begin searching vertically below the designated cell to find the uppermost active cell. If it finds an active cell in the vertical column, leakage across the streambed is applied to that cell. If all cells in the vertical column beneath a stream reach are inactive or if the cell corresponding to the stream reach is a constant head cell, no interaction with ground water is allowed and flow in the stream reach is passed to the next reach.

\section{Integration of MODFLOW-GWT with SFR1 and LAK3 Packages}

The MODFLOW-GWT model (Konikow and others, 1996; Kipp and others, 1998), which includes the GWT Process for MODFLOW-2000, has been modified to ensure compatibility with the SFR1 Package and the LAK3 Package (Merritt and Konikow, 2000). The new code allows the model to calculate the concentration of a single solute in a stream network and in lakes based on a mass-balance approach in which all inflows and outflows of both water and solute are accounted. Thus, the model allows solute to be routed through a stream network and accounts for inputs from (and leakage losses to) ground-water systems, in which the solute concentration may vary in space and time. The major steps in the calculation procedure of MODFLOW-GWT with the integrated SFR1 and LAK3 Packages are illustrated in figure 19.

The SFR1 Package includes a number of output control parameters that control the frequency and type of output written to the MODFLOW listing file or to separate output files. These parameters also control the frequency of writing output related to the solute calculations. Output related to solute transport, however, is written to the GWT listing file (FTYPE $=$ CLST). Solute output from the SFR1 Package is also controlled by the GWT output control parameter NPNTCL, which is a flag for frequency of printing concentration data. Also, if the Gage Package is implemented simultaneously with MODFLOW-GWT and the SFR1 Package, solute concentration at the location of the "gage" will be recorded (in addition to other model results) at the end of every transport time increment. 


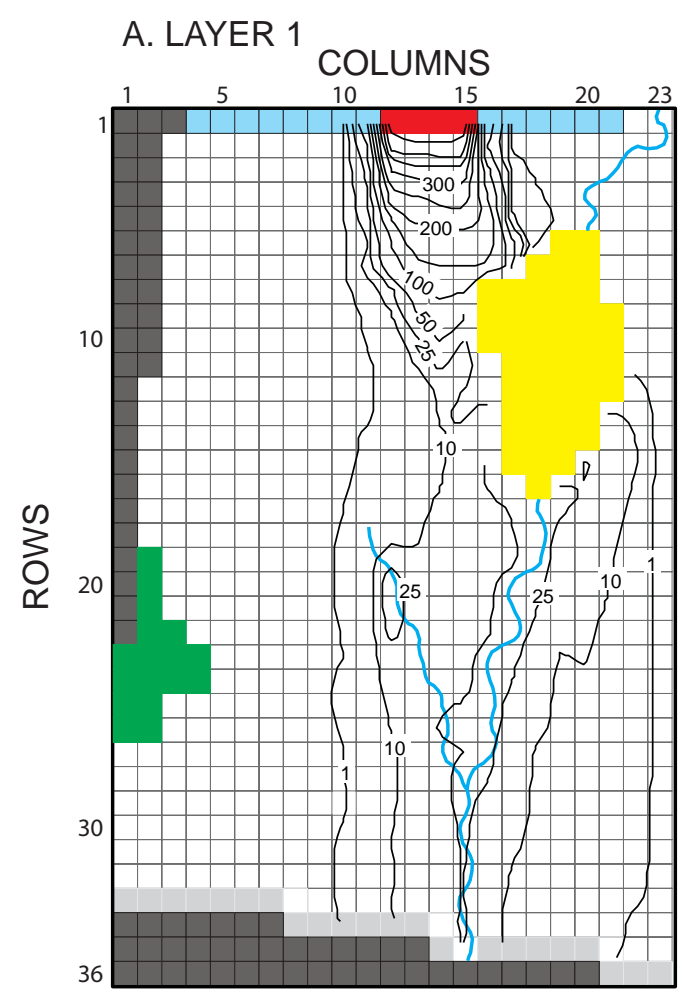

\section{B. LAYER 3}

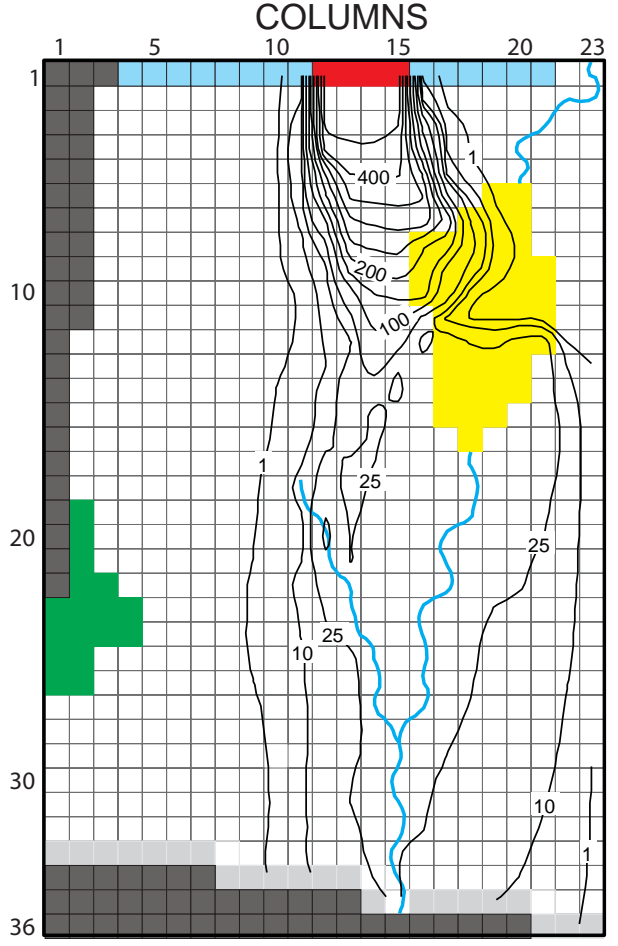

C. LAYER 5

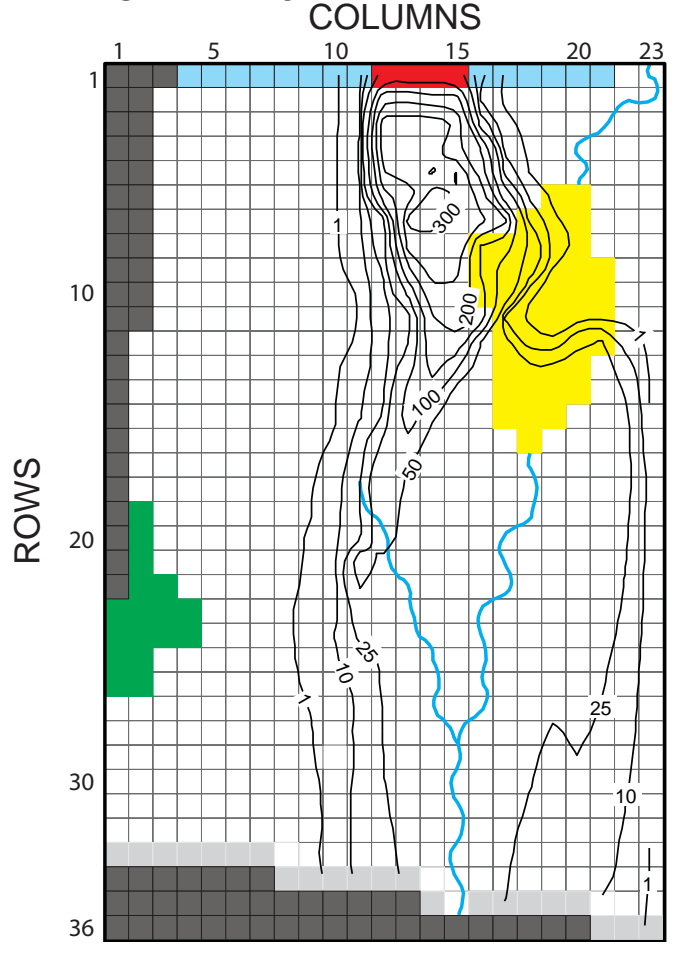

\section{EXPLANATION}

Inactive cells

Constant head at 50.0 feet, and concentration in fluid source is zero

Constant head from $\mathbf{5 0 . 1 0}$ to $\mathbf{5 0 . 1 5}$ feet, and constant concentration in fluid source of 500 micrograms per liter

$\square$ Constant head at 28.0 feet

Lake 1

Lake 2

Stream

Line of equal solute concentration, in micrograms per liter-Contour interval is 50 micrograms per liter; supplementary contours at 1, 10, and 25 micrograms per liter

Figure 17. Simulated boron concentrations in $(A)$ layer $1,(B)$ layer 3 , and $(C)$ layer 5 after 25 years of steady flow and transient solute transport in test simulation 2. 


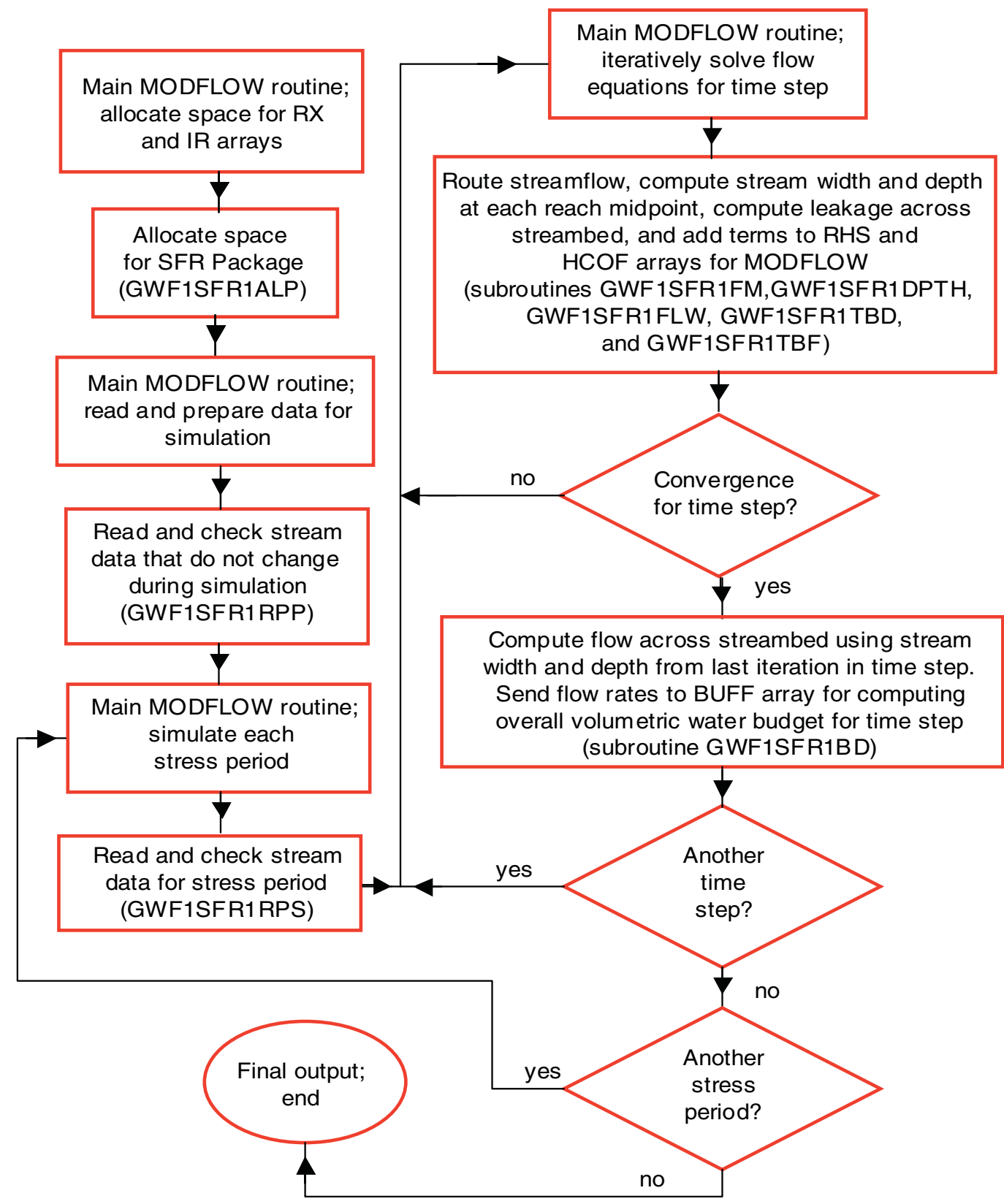

Figure 18. Generalized flow chart illustrating major components of the Streamflow-Routing (SFR1) Package in MODFLOW-2000. 


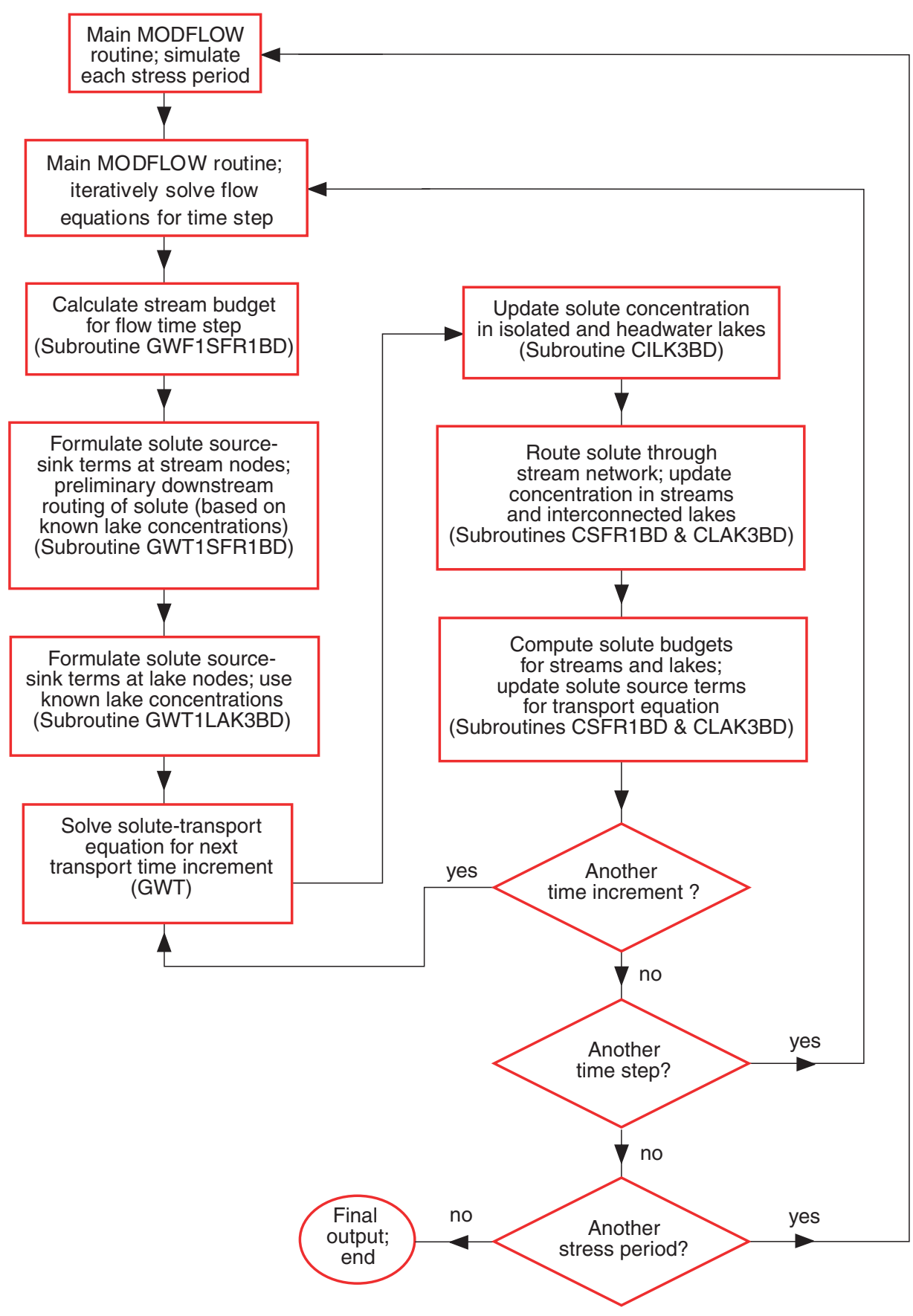

Figure 19. Generalized flow chart illustrating major calculation steps in the integrated Streamflow-Routing (SFR1) and Lake (LAK3) Packages with MODFLOW-2000 and the Ground-Water Transport (GWT) Process, starting with solution of flow equation by a MODFLOW solver package. 


\section{Summary}

The new Streamflow-Routing (SFR1) Package has several enhancements over the previous Stream (STR1) Package. A new capability is the linking of the SFR1 Package to the Lake (LAK3) Package and the Ground-Water Transport (GWT) Process of MODFLOW-2000 (MODFLOW-GWT). An important difference between the SFR1 Package and the previous the STR1 Package is that stream depth is computed at the midpoint of the reach in the SFR1 Package instead of at the beginning of a reach. This approach allows for the addition of water along the reach from precipitation and overland flow and the removal of water by evapotranspiration, in addition to simulating leakage through the streambed. Because streamflow and depth at the midpoint of a stream reach are dependent on leakage through the streambed, stream depth, and leakage are solved using Newton's method.

Streams are divided into segments and reaches. A stream segment is a group of reaches that have similar properties (streambed hydraulic conductivity, streambed geometry, precipitation, evaporation, and overland runoff) and solver (ICALC) options, but only have inflow from tributary streams at the beginning of the segment and outflow from diversions either at the beginning of a segment (such as a point diversion into a pipeline) or at the end of a segment (such as an unlined canal or a split in the natural stream channel). A reach is the part of a segment that is within a single model cell. Several stream reaches (corresponding to different stream segments) can be within a single cell but a single reach cannot interact with more than one cell.

The program allows for five options for simulating stream depth at the midpoint of a reach. For the first option, stream depth is specified and remains constant unless flow at the midpoint of a reach is zero, then stream depth is set to zero. For the second option, stream depth is computed using Manning's equation assuming a wide rectangular channel. For the third option, stream depth, width, and wetted perimeter are computed using Manning's equation assuming an eight-point cross section. For the fourth option, stream depth and width are computed using power functions to relate depth and width to flow. For the last option, stream depth and width are computed using a table of values that relate depth and width to flow. Each stream segment can use a different option for computing stream depth. Also, outflow from lakes (defined by the LAK3 Package) can be computed using any of the five options on the basis of lake stage and streambed elevation at the beginning of the first reach that corresponds to the lake outlet. In this case, the outflow computed from the lake is routed into the first reach of an outlet stream segment.
When Manning's equation with the eight-point cross section is used to compute stream depth, streambed conductance can vary as a function of the wetted perimeter. When the power functions or the table of values are used to relate streamflow to stream depth and width, streambed conductance can vary as a function of width. This means that the streambed conductance no longer needs to be recomputed separately whenever the area of the streambed changes as a function of flow.

Several options have been added for the diversion of water from a stream. For the first option, specified flow is diverted from the stream unless flow in the stream is less than that specified for the diversion, in which case all available flow is diverted from the stream. The second option is the same as the first, except when flow in the stream is less than that specified, in which case no flow is diverted from the stream. For the third option, a percentage of flow is diverted from the stream. For the last option, water is diverted only when flow in the stream exceeds a specified rate. The last option typically is used for flood control.

MODFLOW-GWT has been modified for compatibility with the SFR1 Package. When the GWT Process is activated in combination with the SFR1 Package, the concentration of a single solute is computed in a stream network using a massbalance approach, in which all inflows and outflows of both water and solute are accounted for. Thus, the model allows solute to be routed through a stream network and accounts for inputs from (and leakage losses to) ground-water systems, in which the solute concentration may vary in space and time. Also, solute transport can be simulated between ground water and a network of streams and lakes.

The assumption that streamflow and associated dissolved solutes are routed between stream reaches only on the basis of continuity may limit the applicability of SFR1. The SFR1 Package is designed for modeling long-term changes (months to hundreds of years) in ground-water flow and solutes using averaged flows in streams. The approach generally is reasonable because ground-water flow velocities are usually much less than flow velocities in open channels. The SFR1 Package (nor STR1) is not recommended for modeling the transient exchange of water between stream reaches and shallow ground water when the objective is to examine short-term (minutes to days) effects caused by rapidly changing streamflows, in which changes in storage in the stream channel are important. The assumption that solutes are completely mixed within each stream reach has general applicability for many small streams, but may not be applicable for large rivers or when simulating short-term effects caused by rapidly changing streamflows. 


\section{References Cited}

Burden, R.L, and Faires, J.D., 1997, Numerical Analysis (6th ed.): Pacific Grove, Calif., Brooke/Cole Publishing Co., $811 \mathrm{p}$.

Chow, V.T., Maidment, D.R., and Mays, L.W., 1988, Applied Hydrology: New York, McGraw-Hill, Inc., 572 p.

Danskin, W.R. and Hanson, R.T., 2002, Appendix 2: Documentation and description of changes made to the StreamflowRouting Package in the MODFLOW ground-water flow model, in Hanson, R.T., Martin, Peter, and Koczot, K.M., Simulation of ground-water/surface-water flow in the Santa Clara-Calleguas Basin, Ventura County, California: U.S. Geological Survey Water-Resources Investigation Report 02-4136, p. 187-193.

Harbaugh, A.W., and McDonald, M.G., 1996a, Programmer's documentation for MODFLOW-96, an update to the U.S. Geological Survey modular finite-difference ground-water flow model: U.S. Geological Survey Open-File Report 96-486, $220 \mathrm{p}$.

Harbaugh, A.W., and McDonald, M.G., 1996b, User's documentation for MODFLOW-96, an update to the U.S. Geological Survey modular finite-difference ground-water flow model: U.S. Geological Survey Open-File Report 96-485, $56 \mathrm{p}$.

Harbaugh, A.W., Banta, E.R., Hill, M.C., and McDonald, M.G., 2000, MODFLOW-2000, The U.S. Geological Survey modular ground-water model-User guide to modularization concepts and the ground-water flow process: U.S. Geological Survey Open-File Report 00-92, 121 p.

Hill, M.C., Banta, E.R., Harbaugh, A.W., and Anderman, E.R., 2000, MODFLOW-2000, the U.S. Geological Survey modular ground-water model-User guide to the Observation, Sensitivity, and Parameter-Estimation Processes and three post-processing programs: U.S. Geological Survey OpenFile Report 00-184, 209 p.

Jobson, H.E., and Harbaugh, A.W., 1999, Modifications to the diffusion analogy surface-water flow model (DAFLOW) for coupling to the modular finite-difference ground-water flow model (MODFLOW): U.S. Geological Survey Open-File Report 99-217, 107 p.
Kipp. K.L., Jr., Konikow, L.F., and Hornberger, G.Z., 1998, An implicit dispersive transport algorithm for the U.S. Geological Survey MOC3D solute-transport model: U. S. Geological Survey Water-Resources Investigations Report 98-4234, $54 \mathrm{p}$.

Konikow, L.F., and Bredehoeft, J.D., 1974, Modeling flow and chemical-quality changes in an irrigated stream-aquifer system: Water Resources Research, v. 10, no. 3, p. 546-562.

Konikow, L.F., Goode, D.J., and Hornberger, G.Z., 1996, A three-dimensional method-of-characteristics solute-transport model (MOC3D): U.S. Geological Survey Water-Resources Investigations Report 96-4267, 87 p.

LeBlanc, D.R., 1984, Sewage plume in a sand and gravel aquifer, Cape Cod, Massachusetts: U.S. Geological Survey Water-Supply Paper 2218, 28 p.

Leopold, L.B., Wolman, M.G., and Miller, J.P., 1992, Fluvial processes in geomorphology: Mineola, New York, Dover Publications, Inc., $522 \mathrm{p}$.

McDonald, M.G., and Harbaugh, A.W., 1984, A modular threedimensional finite-difference ground-water flow model: U.S. Geological Survey Open-File Report 83-875, 528 p.

McDonald, M.G., and Harbaugh, A.W., 1988, A modular threedimensional finite-difference ground-water flow model: U.S. Geological Survey Techniques of Water-Resources Investigations, Book 6, Chapter A1, 586 p.

Merritt, M.L., and Konikow, L.F., 2000, Documentation of a computer program to simulate lake-aquifer interaction using the MODFLOW ground-water flow model and the MOC3D solute-transport model: Water-Resources Investigations Report 00-4167, 146 p.

Prudic, D.E., 1989, Documentation of a computer program to simulate stream-aquifer relations using a modular, finitedifference, ground-water flow model: U.S. Geological Survey Open-File Report 88-729, 113 p.

Swain, E.D., and Wexler, E.J., 1996, A coupled surface-water and ground-water flow model (MODBRANCH) for simulation of stream-aquifer interaction: U.S. Geological Survey Techniques of Water-Resources Investigations, Book 6, Chapter A6, 125 p. 

APPENDIXES 



\section{APPENDIX 1: DATA INPUT INSTRUCTIONS FOR STREAMFLOW-R्OUTING (SFR1) PACKAGE}

\section{MODFLOW Name File}

Streamflow routing is activated by including a record in the MODFLOW name file using the file type (Ftype) "SFR" to indicate that relevant calculations are to be made in the model and to specify the related input data file. The user can optionally specify that stream gages and monitoring stations are to be represented at one or more locations along a stream channel by including a record in the MODFLOW name file using the file type (Ftype) "GAGE” that specifies the relevant input data file giving locations of gages. The SFR1 Package is compatible with MODFLOW-2000 (Harbaugh and others, 2000), but not with earlier versions of MODFLOW.

\section{Streamflow-Routing Package Input Data}

The SFR1 Package input file consists of input items numbered from 0 through 7 , each consisting of one or more records, as described in detail below. These data are used to specify information about the locations, interconnections, flows, physical and hydraulic properties of the streambed, and possibly solute concentrations associated with the streams, as well as specifying certain output control options.

All input variables are read using free formats, unless specifically indicated otherwise. In free format, variables are separated by one or more spaces or by a comma and optionally one or more spaces. Thus in free format, a blank field cannot be used to set a variable value to zero.

Parameters can be used to define the streambed hydraulic conductivity (refer to Harbaugh and others, 2000, p. 4 and p. 12-18 for an explanation of parameters used in MODFLOW-2000); however, the current version of the SFR1 Package is only partially compatible with the Sensitivity and Parameter-Estimation Processes of MODFLOW-2000 (Hill and others, 2000). Although SFR-type parameters may be listed in the Sensitivity Process input file, the program does not support calculation of sensitivities for, or estimation of, parameters defined in SFR1. Therefore, SFR-type parameters listed in the Sensitivity Process input file may not have ISENS values greater than zero; also, when an SFR-type parameter is listed in the Sensitivity Process input file, ISENALL may not be greater than zero. More importantly, when the SFR1 Package is used, parameters defined in packages other than SFR1 can have sensitivities calculated or be estimated only when ICALC is specified as either 0 or 1 for all stream segments in the SFR1 Package.

When parameters are to be used, NSFRPAR of Item 1 (below) must be greater than zero, and Items 3, 4, and 7 must be present. Parameter definitions are supplied in Items 3 and 4 , and parameters are activated each stress period in Item 7 . In addition to the parameter-controlled segments activated by Item 7, non-parameter-controlled segments may be specified each stress period by setting ITMP of Item 5 greater than zero and providing ITMP repetitions of Item 6 . When parameters are not to be used, NSFRPAR must equal zero, and Items 3, 4, and 7 must be omitted; in this situation, streams are simulated 
using only ITMP and repetitions of Item 6. In each stress period, the sum of ITMP plus the sum of all NLST values in Item 3 associated with the NP parameters listed in Item 7 must equal or be less than (if some stream segments are inactive) the total number of stream segments in the stream network (NSS of Item 1). Stream segments defined by Items 3, 4 and 7 cannot be repeated using ITMP and Item 6 .

\section{FOR EACH SIMULATION:}

0. Data: [\#Text]

Text A character variable (up to 199 characters) that is printed when the file is read. The “\#” character must be in column 1, and, accordingly, the variable starts in column 2. Any characters can be included in Text.

Note 1: Item 0 can be repeated multiple times.

1. Data: NSTRM NSS NSFRPAR NPARSEG CONST DLEAK ISTCB1 ISTCB2

NSTRM An integer value equal to the number of stream reaches (finite-difference cells) that are active during the simulation. The value of NSTRM also represents the number of lines of data to be included in Item 2, described below.

NSS An integer value equal to the number of stream segments (consisting of one or more reaches) that are used to define the complete stream network. The value of NSS represents the number of segments that must be defined through a combination of parameters and repetitions of Item 6 every stress period.

NSFRPAR An integer value equal to the number of stream parameters (associated with one or more segments) to be defined.

NPARSEG An integer value equal to (or exceeding) the number of stream-segment definitions associated with all parameters. This number can be more than the total number of segments (NSS) in the stream network because the same segment can be defined in multiple parameters, and because parameters can be time-varying. NPARSEG must equal or exceed the sum of NLST $\times \mathrm{N}$ for all parameters, where $\mathrm{N}$ is the greater of 1 and NUMINST; that is, NPARSEG must equal or exceed the total number of repetitions of item 4b.

CONST A real value (or conversion factor) used in calculating stream depth for stream reach. If stream depth is not calculated using Manning's equation for any stream segment (that is, ICALC does not equal 1 or 2 ), then a value of zero can be entered. If Manning's equation is used, a constant of 1.486 is used for flow units of cubic feet per second, and a constant of 1.0 is used for units of cubic meters per second. The constant must be multiplied by 86,400 when using time units of days in the simulation. An explanation of time units used in MODFLOW is given by Harbaugh and others (2000, p. 10.)

DLEAK A real value equal to the tolerance level of stream depth used in computing leakage between each stream reach and active model cell. Value is in units 
of length. Usually a value of 0.0001 is sufficient when units of feet or meters are used in model.

ISTCB1 An integer value used as a flag for writing stream-aquifer leakage values. If ISTCB1 $>0$, it is the unit number to which unformatted leakage between each stream reach and corresponding model cell will be saved to a file whenever the cell-by-cell budget has been specified in Output Control (see Harbaugh and others, 2000, pages 52-55). If ISTCB1 = 0, leakage values will not be printed or saved. If ISTCB1 < 0 , all information on inflows and outflows from each reach; on stream depth, width, and streambed conductance; and on head difference and gradient across the streambed will be printed in the main listing file whenever a cell-by-cell budget has been specified in Output Control.

ISTCB2 An integer value used as a flag for writing to a separate formatted file all information on inflows and outflows from each reach; on stream depth, width, and streambed conductance; and on head difference and gradient across the streambed. If ISTCB2 >0, then ISTCB2 also represents the unit number to which all information for each stream reach will be saved to a separate file when a cell-by-cell budget has been specified in Output Control. If ISTCB2 $\leq 0$, information will not be saved to a separate file.

Note 2: The first two variables (NSTRM and NSS) are used for dimensioning arrays, and must be equal to the actual number of stream reaches defined in Item 2 and the number of segments that define the complete stream network, respectively.

Note 3: The SFR1 Package differs from the previous Stream (STR1) Package because the new package solves for stream depth at the midpoint of each reach instead of at the beginning of the reach. To solve for depth at the midpoint of each reach, the SFR1 Package uses Newton's iterative method and consequently, a tolerance (DLEAK) is used for stopping the iterative process within the SFR1 Package.

\section{One record for each stream reach:}

\section{Data: KRCH IRCH JRCH ISEG IREACH RCHLEN}

$\mathrm{KRCH} \quad$ An integer value equal to the layer number of the cell containing the stream reach.

IRCH An integer value equal to the row number of the cell containing the stream reach.

JRCH An integer value equal to the column number of the cell containing the stream reach.

ISEG An integer value equal to the number of stream segment in which this reach is located. Stream segments contain one or more reaches and are assumed to have uniform or linearly varying characteristics.

IREACH An integer value equal to the sequential number in a stream segment of this reach (where a reach corresponds to a single cell in the model). Numbering of reaches in a segment begins with 1 for the farthest upstream reach and continues in downstream order to the last reach of the segment. 
RCHLEN A real number equal to the length of channel of the stream reach within this model cell. The length of a stream reach can exceed the model cell dimensions because of the meandering nature of many streams. The length is used to calculate the streambed conductance for this reach. Also, the sum of the lengths of all stream reaches within a segment is used to calculate the average slope of the channel for the segment and subsequently other values, such as the elevation of the streambed and stream stage.

Note 4: Records are read in sequential order from upstream to downstream, first by segments, and then sequentially by reaches. Segments should be numbered in downstream order but is not an absolute necessity. If the segments are not numbered in downstream order, the inflows and outflows from each segment will still be computed but the computed inflows into a segment from upstream tributary streams having a higher segment number will be from the previous iteration. Reaches must be listed and read in sequentially because the order determines the connections of inflows and outflows within a stream segment.

Note 5: The stream network is assumed to remain fixed geometrically over the duration of a simulation. The active part of the stream network, however, can be made to vary over time by making selected stream segments inactive for selected stress periods. This would be implemented by setting the streambed hydraulic conductivity, segment inflow, overland runoff, and direct precipitation to zero for the inactive segments in Item 4 for the specific stress periods when they are known to be inactive or dry.

Note 6: If the model cell corresponding to a stream reach is inactive, the program will search for the uppermost active cell in the vertical column to apply the leakage. If there are no active cells or if the cell is a constant head, no interaction is allowed and flow in the reach is passed to the next reach.

\section{When NSFRPAR = 0, skip Items 3 and 4 and enter all stream segment data using Items 5 and 6; and}

\section{When NSFRPAR $>0$, Items 3 and 4 are repeated NSFRPAR times:}

\section{Data: PARNAM PARTYP Parval NLST [INSTANCES NUMINST]}

PARNAM A set of characters used to name a parameter to be defined. This name can consist of 1 to 10 characters and is not case sensitive. That is, any combination of the same characters with different cases will be equivalent.

PARTYP Type of parameter to be defined. For the SFR1 Package, the only allowed parameter type is SFR, which defines values of the streambed hydraulic conductivity.

Parval A real number that is a parameter value that may be overridden by a value in the Sensitivity Process input file or by a value generated by the ParameterEstimation Process.

NLST An integer value that is the number of stream segments associated with this parameter (this value also indicates how many times Item 4 is repeated in the next block of input data). 
INSTANCES An optional keyword that designates a parameter as time varying. The keyword is case-insensitive; that is, it may be entered in any combination of upper- and lower-case letters. If INSTANCES is present, it must be followed by a value for NUMINST. If INSTANCES is absent, PARNAM is non-time-varying and NUMINST should not be present.

NUMINST An integer value that is the number of instances that are included in the definition of a time-varying parameter, where each instance is a sequence of Item 4 (Parts $4 \mathrm{~b}$ through $4 \mathrm{~g}$ ) defining reaches and associated properties. If the keyword INSTANCES is present, NUMINST must be present and must be at least 1 . If the keyword INSTANCES is absent, NUMINST should not be present.

\title{
When PARNAM is not time-varying, Part $4 a$ is not read, and Parts $4 \mathrm{~b}$ through $4 \mathrm{~g}$ are read sequentially for each of NLST stream segments; and
}

\section{When PARNAM is time-varying, NUMINST instances are read. For each instance, Part $4 \mathrm{a}$ is read, and then Parts $4 \mathrm{~b}$ through $4 \mathrm{~g}$ are read sequentially for each of NLST stream segments (see notes 7 and 8):}

\begin{abstract}
4a. Data: $\quad\{$ INSTNAM $\}$
INSTNAM The name of an instance associated with the parameter PARNAM specified in the corresponding Item 3 (INSTNAM is read only if PARNAM is timevarying). The name can consist of 1 to 10 characters and is not case sensitive. That is, any combination of the same characters with different case will be equivalent. Names entered for INSTNAM must be unique for any given parameter, but names may be reused for instances associated with different parameters.
\end{abstract}

\section{4b. Data: NSEG ICALC OUTSEG IUPSEG \{IPRIOR\} \{NSTRPTS $\}$ FLOW RUNOFF ETSW PPTSW $\{$ ROUGHCH $\} \quad\{$ ROUGHBK $\} \quad\{\mathrm{CDPTH}\}$ $\{$ FDPTH $\} \quad\{$ AWDTH $\} \quad\{$ BWDTH $\}$}

NSEG An integer value of the stream segment for which information is given to identify inflow, outflow, and computation of stream depth.

ICALC An integer value used to indicate method used to calculate stream depth in this segment.

- If ICALC $\leq 0$, stream depth in each reach is specified at the beginning of a stress period and remains unchanged unless flow at the midpoint of a reach is zero, then depth is set to zero in that reach.

- If ICALC $>0$, stream depth is calculated and updated each iteration of the MODFLOW solver within a time step.

- If ICALC = 1, stream depth is calculated using Manning's equation and assuming a wide rectangular channel.

- If ICALC = 2, stream depth is calculated using Manning's equation and assuming an eight-point channel cross section for each segment (which allows for the computation of a wetted perimeter and for changing hydraulic conductance of the streambed in relation to changes in flow). 
- If ICALC = 3, stream depth and width are calculated using a power function relating each to streamflow $(Q)$ using equations 8 and 9 where $\operatorname{DEPTH}(y)=\mathrm{CDPTH} \times \mathrm{Q}^{\text {FDPTH }}$ and $\operatorname{WIDTH}(w)=\mathrm{AWDTH} \times \mathrm{Q}^{\mathrm{BWDTH}}$

- If ICALC $=4$, stream depth and width are calculated using a table relating streamflow to depth and width (the table is defined in Part 4f).

OUTSEG

An integer value of the downstream stream segment that receives tributary inflow from the last downstream reach of this segment. If this segment (identified by NSEG) does not feed (or discharge into) another downstream (tributary) segment, then enter a value of "0" for this variable (Segment 7 in figure 3 is an example for which OUTSEG $=0$ ). If the segment ends within the modeled grid and OUTSEG $=0$, outflow from the segment is not routed anywhere and is no longer part of the stream network. One may wish to use this if all flow in the stream gets diverted into a lined canal or into a pipe. If the flow out of this segment discharges into a lake, set OUTSEG equal to the negative value of the lake identification number (where the minus sign is used as a flag to tell the model that flow enters a lake rather than a tributary stream segment).

IUPSEG An integer value of the upstream segment from which water is diverted (or withdrawn) to supply inflow to this stream segment if this segment originates as a diversion from an upstream segment. If the source of a stream segment is discharge from a lake, set IUPSEG equal to the negative value of the lake identification number (where the minus sign is used as a flag to tell the model that streamflow into this segment is derived from lake outflow rather than a stream segment). If this stream segment (identified by NSEG) does not receive inflow as a diversion from an upstream segment, then set IUPSEG $=0$.

IPRIOR An integer value that only is specified if IUPSEG $>0$ (do not specify a value in this field if IUPSEG $=0$ or IUPSEG $<0$ ). IPRIOR defines the prioritization system for diversion, such as when insufficient water is available to meet all diversion stipulations, and is used in conjunction with the value of FLOW (specified below).

- When IPRIOR $=0$, then if the specified diversion flow (FLOW) is greater than the flow available in the stream segment from which the diversion is made, the diversion is reduced to the amount available, which will leave no flow available for tributary flow into a downstream tributary of segment IUPSEG.

- When IPRIOR = -1 , then if the specified diversion flow (FLOW) is greater than the flow available in the stream segment from which the diversion is made, no water is diverted from the stream. This approach assumes that once flow in the stream is sufficiently low, diversions from the stream cease, and is the "priority" algorithm that originally was programmed into the STR1 Package (Prudic, 1989).

- When IPRIOR = -2, then the amount of the diversion is computed as a fraction of the available flow in segment IUPSEG; in this case, FLOW is a value between 0 and 1 .

- When IPRIOR = -3 , then a diversion is made only if the streamflow leaving segment IUPSEG exceeds the value of FLOW. If this occurs, then the quantity of water diverted is the excess flow and the quantity that flows 
from the last reach of segment IUPSEG into its downstream tributary (OUTSEG) is equal to FLOW. This represents a flood-control type of diversion, as described by Danskin and Hanson (2002).

NSTRPTS An integer value specified only when ICALC $=4$. It is used to dimension a table relating streamflow with stream depth and width as specified in Items 4e and 6e. NSTRPTS must be at least 2 but not more than 50. If the table exceeds $3 \times 50$ (for streamflow, stream depth, and width) values, then MAXPTS in the allocation subroutine GWF1SFR1ALP will need to be increased from $3 \times 50$ to $3 \times$ (the desired maximum value).

FLOW A real number that is the streamflow (in units of volume per time) entering or leaving the upstream end of a stream segment (that is, into the first reach). - If the stream is a headwater stream, FLOW defines the total inflow to the first reach of the segment. The value can be any number $\geq 0$.

- If the stream is a tributary stream, FLOW defines additional specified inflow to or withdrawal from the first reach of the segment (that is, in addition to the discharge from the upstream segment of which this is a tributary). This additional flow does not interact with the ground-water system. For example, a positive number might be used to represent direct outflow into a stream from a sewage treatment plant, whereas a negative number might be used to represent pumpage directly from a stream into an intake pipe for a municipal water treatment plant. (Also see additional explanatory notes below.)

- If the stream is a diversionary stream, and the diversion is from another stream segment, FLOW defines the streamflow diverted from the last reach of stream segment IUPSEG into the first reach of this segment. The diversion is computed or adjusted according to the value of IPRIOR. - If the stream is a diversionary stream, and the diversion is from a lake, FLOW defines a fixed rate of discharge diverted from the lake into the first reach of this stream segment (unless the lake goes dry) and flow from the lake is not dependent on the value of ICALC. However, if FLOW $=0$, then the lake outflow into the first reach of this segment will be calculated on the basis of lake stage relative to the top of the streambed for the first reach using one of the methods defined by ICALC.

RUNOFF A real number that is the volumetric rate of the diffuse overland runoff that enters the stream segment (in units of volume per time). The specified rate is apportioned to each reach of the segment in direct relation to the fraction of the total length of the stream channel in the segment that is present in each reach.

ETSW A real number that is the volumetric rate per unit area of water removed by evapotranspiration directly from the stream channel (in units of length per time). ETSW is defined as a positive value.

PPTSW A real number that is the volumetric rate per unit area of water added by precipitation directly on the stream channel (in units of length per time).

ROUGHCH A real number that is Manning's roughness coefficient for the channel in all reaches in this segment. This variable is only specified if ICALC $=1$ or 2 .

ROUGHBK A real number that is Manning's roughness coefficient for the overbank areas in all reaches in this segment. This variable is only specified if ICALC $=2$. 
CDPTH A real number that is the coefficient used in the equation: $\left(\mathrm{DEPTH}=\mathrm{CDPTH} \times \mathrm{Q}^{\mathrm{FDTH}}\right)$ that relates stream depth in all reaches in this segment to streamflow. This variable is only specified if ICALC $=3$.

FDPTH A real number that is the coefficient used in the equation: $\left(\mathrm{DEPTH}=\mathrm{CDPTH} \times \mathrm{Q}^{\mathrm{FDPTH}}\right)$ that relates stream depth in all reaches in this segment to streamflow. This variable is only specified if ICALC $=3$.

AWDTH A real number that is the coefficient used in the equation: $\left(\mathrm{WIDTH}=\mathrm{AWDTH} \times \mathrm{Q}^{\mathrm{BWDTH}}\right)$ that relates stream width in all reaches in this segment to streamflow. This variable is only specified if ICALC $=3$.

BWDTH A real number that is the coefficient used in the equation: $\left(\mathrm{WIDTH}=\mathrm{AWDTH} \times \mathrm{Q}^{\mathrm{BWDTH}}\right)$ that relates stream width in all reaches in this segment to streamflow. This variable is only specified if ICALC $=3$.

4c. Data: Hclfact THICKM1 ELEVUP \{WIDTH1\} \{DEPTH1\}

Hclfact A real number that is a factor used to calculate hydraulic conductivity of the streambed at the upstream end of this segment from the parameter value (in units of length per time).

THICKM1 A real number that is the thickness of streambed material at the upstream end of this segment (in units of length).

ELEVUP A real number that is the elevation of the top of the streambed at the upstream end of this segment (in units of length).

WIDTH1 A real number that is the average width of the stream channel at the upstream end of this segment (in units of length). This variable is only specified if ICALC $\leq 1$.

DEPTH1 A real number that is the average depth of water in the channel at the upstream end of this segment (units of length). This variable is only specified if ICALC $=0$, in which case the stream stage in a reach is assumed to equal the elevation of the top of the streambed plus the depth of water.

4d. Data: Hc2fact THICKM2 ELEVDN $\{$ WIDTH2 $\}$ \{DEPTH2

Hc2fact A real number that is the factor used to calculate hydraulic conductivity of the streambed at the downstream end of this segment from the parameter value (units of length per time).

THICKM2 A real number that is the thickness of streambed material at the downstream end of this segment (untis of length).

ELEVDN A real number that is the elevation of the top of the streambed at the downstream end of this segment (units of length).

WIDTH2 A real number that is the average width of the stream channel at the downstream end of this segment (units of length). This variable is only specified if ICALC $\leq 1$.

DEPTH2 A real number that is the average depth of water in the channel at the downstream end of this segment (units of length). This variable is only specified if ICALC $=0$, in which case the stream stage in a reach is assumed to equal the elevation of the top of the streambed plus the depth of water. 
If $\mathrm{ICALC}=\mathbf{2}$ :

4e. Data: XCPT1 XCPT2 ... XCPT8

Data: ZCPT1 ZCPT2 ... ZCPT8

$\mathrm{XCPT} i \quad$ A real number that is the distance relative to the left bank of the stream channel (when looking downstream) for the eight points (XCPT1 through $\mathrm{XCPT} 8$ ) used to describe the geometry of this segment of the stream channel. By definition, location XCPT1 represents the left edge of the channel cross section, and its value should be set equal to 0.0 ; values $\mathrm{XCPT} 2$ through XCPT8 should equal to or be greater than the previous distance. See figures 4 or 9 for examples.

$\mathrm{ZCPT} i \quad$ A real number that is the height relative to the top of the lowest elevation of the streambed (thalweg). One value (ZCPT1 through ZCPT8) is needed for each of the eight horizontal distances defined by XCPTi. The location of the thalweg (set equal to 0.0) can be any location from XCPT2 through XCPT7.

If ICALC $=4$ :
4f. Data: FLOWTAB (1) FLOWTAB (2) ... FLOWTAB (NSTRPT)
Data: DPTHTAB (1) DPTHTAB (2) ... DPTHTAB (NSTRPTS)
Data: WDTHTAB (1) WDTHTAB (2) ... WDTHTAB (NSTRPTS)

FLOWTAB A real number that is the streamflow (units of volume per time) related to a given depth and width. One value is needed for each streamflow that has a corresponding value of depth and width up to the total number of values used to define the table-FLOWTAB (1) through FLOWTAB (NSTRPTS). NSTRPTS is defined in Part $4 \mathrm{~b}$.

DPTHTAB A real number that is the average depth (units of length) corresponding to a given flow. The number and order of values, DPTHTAB (1) through DPTHTAB (NSTRPTS) must coincide with the streamflow values (FLOWTAB) listed on the line immediately preceding.

WDTHTAB A real number that is the stream width (units of length) corresponding to a given flow. The number and order of values, WDTHTAB (1) through WDTHTAB (NSTRPTS), must coincide with the streamflow values (FLOWTAB) listed on first line in Part 4f.

\section{If Ground-Water Transport (GWT) Process is active (Ftype "GWT" exists), then read Part $4 \mathrm{~g}$ NSOL times (where NSOL is the number of solutes being simulated, see note 15):}

4g. Data: \{CONCQ (NSOL) $\}$ CONCRUN (NSOL) CONCPPT (NSOL)

CONCQ A real number that is the solute concentration associated with "FLOW" (Part $4 \mathrm{~b}$ - specified flow entering the upstream end of the stream segment). Only specify this variable for stream segments where IUPSEG $=0$. 
CONCRUN A real number that is the solute concentration in the overland runoff entering the stream segment.

CONCPPT A real number that is the solute concentration in precipitation that directly falls onto the stream surface.

NSOL An integer value that is the number of solutes that are being simulated. The version of the Ground-Water Flow (GWT) Process for MODFLOW-2000 (MODFLOW-GWT) documented by Konikow and others (1996) is limited to simulating one solute, and until a new version is released, NSOL must be 1 .

Note 7: Item 4, Parts 4b through 4g must be completed sequentially for each of the NLST stream segments; that is, Parts $4 \mathrm{~b}$ through $4 \mathrm{~g}$ for one stream segment must be entered before Parts $4 \mathrm{~b}$ through $4 \mathrm{~g}$ of the next stream segment. However, the data for stream segments need not be entered sequentially by stream segment number. For example, data for stream segment 2 can be entered before data for stream segment 1 .

Note 8: When the defined parameter (PARNAM) is not time-varying, Item 4, Part 4a is omitted, and each stream segment controlled by parameter PARNAM is defined by one sequence of Parts $4 \mathrm{~b}$ through $4 \mathrm{~g}$. When the defined parameter (PARNAM) is time-varying, Item 4, Parts 4a through 4g must be completed for each of NUMINST instances. For each instance, Part 4a is defined followed by Parts $4 \mathrm{~b}$ through $4 \mathrm{~g}$ for each of the NLST stream segments associated with that instance. For example, NUMINST $=2$, NLST $=3$, ICALC $=1$ and the GWT Process is inactive, the sequence of records for Item 4 would be: 4a, 4b, 4c, 4d, 4b, 4c, 4d, 4b, 4c, 4d, 4a, 4b, 4c, 4d, 4b, 4c, 4d, 4b, 4c, and 4d.

Note 9: Record 4b will contain 8 to 13 variables; depending on the values of ICALC and IUPSEG. (ICALC determines how stream depth is to be calculated; when ICALC is 1 or 2, depth is calculated using Manning's equation, which, in turn, requires a channel roughness coefficient ( ICALC $=1$ ) or a channel and bank roughness coefficient (ICALC $=2$ ). Similarly, Parts 4c and 4d will include 3 to 5 values.

Note 10: A stream segment that receives inflow from upstream segments is allowed to have as many as ten upstream segments feeding it, as defined by the respective values of OUTSEG in Part 4b.

Note 11: Stream properties and stresses defined in Parts $4 \mathrm{~b}$ are assumed constant and uniform within a single stream segment. Additionally, hydraulic conductivity, streambed thickness, elevation of top of streambed, stream width, and stream depth may vary smoothly and linearly within a single stream segment. For these variables, data values at the upstream end of the segment are described in Part 4c and data values at the downstream end of the segment are described in Part 4d. Values of these variables for individual reaches of a segment are estimated using linear interpolation. To make any variable the same throughout the segment, simply specify equal values in Parts $4 \mathrm{c}$ and $4 \mathrm{~d}$. The two elevations in Parts 4c and 4d are used in conjunction with the total length of the stream segment (calculated from RECHLEN given for each reach in Item 2) to compute the slope of the stream and the elevations for any intermediate reaches. The streambed thickness is 
subtracted from the top of streambed elevations to calculate the elevations of the bottom of the streambed (used in calculations of leakage).

Note 12: If Part 4e is included (for ICALC $=2$ ), it is assumed that the cross-sectional geometry defined by these data is the same over the entire length of the segment. Similarly, if Part $4 \mathrm{f}$ is included (for ICALC $=4$ ), it is assumed the tabulated relation between streamflow and stream depth and width is the same over the entire length of the segment.

Note 13: If the Lake (LAK3) Package is also implemented, then flow out of the lake into a stream segment is dependent on the option used to compute stream depth ( ICALC $=1,2$, 3 , or 4). Constant discharge from a lake can be simulated no matter what value of ICALC is assigned to the stream segment emanating from the lake by assigning a positive value to FLOW in Part 4b.

Note 14: If a diversionary flow is large enough to warrant representation in the model, but is discharged into a pipeline, lined canal, or other structure or system that does not interact with the aquifer and the flow might exceed the available streamflow, then there is an alternative means to represent it. Instead of specifying a negative value of FLOW, we suggest representing the withdrawal by a single-reach diversionary stream segment, which would be located in the same model cell as the reach from the upstream segment (IUPSEG) from which the diversion is made; specifying the segment's streambed hydraulic conductivity equal to 0 will preclude interaction with the aquifer and setting OUTSEG $=0$ will remove the flow from the system. The diversion will then be subject to the constraints associated with the value of IPRIOR.

Note 15: The version of MODFLOW-GWT documented by Konikow and others (1996) is limited to simulating one solute, and until a new multi-species version is released, NSOL automatically defaults to a value of 1 .

\section{FOR EACH STRESS PERIOD:}

\section{Data: ITMP IRDFLG IPTFLG $\{\mathrm{NP}\}$}

ITMP An integer value for reusing or reading stream segment data that can change each stress period. ITMP $=0$ when all stream segment data is defined by Item 4 (NSFRPAR > 0; number of stream parameters is greater than 0 ). If ITMP $<0$, then stream segment data not defined in Item 4 will be reused from the last stress period (Item 6 is not read for the current stress period). If ITMP $>0$, then stream segment data not defined in Item 4 (for a number of segments equal to the value of ITMP) will be defined in Item 6 below. ITMP must be defined $\geq 0$ for the first stress period of a simulation.

IRDFLG An integer value for printing input data specified for this stress period. If IRDFLG $=0$, input data for this stress period will be printed. If IRDFLG > 0 , then input data for this stress period will not be printed.

IPTFLG An integer value for printing streamflow-routing results during this stress period. If IPTFLG $=0$, or whenever the variable ICBCFL is specified, the 
results for specified time steps during this stress period will be printed. If IPTFLG $>0$, then the results during this stress period will not be printed.

NP

An integer value of the number of parameters used in the current stress period. The parameters being used are subsequently listed in Item 7 below. NP and Item 7 below are not read when NSFRPAR $=0$.

Note 16: In each stress period, the sum of ITMP plus the sum of all NLST values in Item 3 associated with the NP parameters listed in Item 7 must equal or be less than (some stream segments may not be active during a stress period) the total number of stream segments in the stream network (NSS of Item 1). Stream segments defined by Items 3, 4, and 7 cannot be repeated using ITMP and Item 6 .

\section{If ITMP > 0:}

6a. Data: NSEG ICALC OUTSEG IUPSEG \{IPRIOR\} \{NSTRPTS $\}$ FLOW RUNOFF ETSW PPTSW $\{$ ROUGHCH $\} \quad\{$ ROUGHBK $\} \quad\{\mathrm{CDPTH}\}$ $\{$ FDPTH $\} \quad\{$ AWDTH $\} \quad\{$ BWDTH $\}$

See Item 4, Part 4b for variable definitions.

6b. Data: HCOND1 THICKM1 ELEVUP $\{$ WIDTH1 $\}$ DEPTH1

HCOND1 Hydraulic conductivity of the streambed at the upstream end of this segment (units of length per time).

See Item 4, Part 4c for definitions of variables THICKM1, ELEVUP, WIDTH1, and DEPTH1.

6c. Data: HCOND2 THICKM2 ELEVDN \{WIDTH2 $\}$ \{DEPTH2

HCOND2 Hydraulic conductivity of the streambed at the downstream end of this segment (units of length per time).

See Item 4, Part 4d for definitions of variables THICKM2, ELEVDN, WIDTH2, and DEPTH2.

\section{If ICALC = 2:}

6d. Data: XCPT1 XCPT2 ... XCPT8

Data: ZCPT1 ZCPT2 ... ZCPT8

See Item 4, Part 4e for variable definitions.

If ICALC = 4:

6e. Data: FLOWTAB (1) FLOWTAB (2) ... FLOWTAB (NSTRPTS)

Data: DPTHTAB (1) DPTHTAB (2) ... DPTHTAB (NSTRPTS)

Data: WDTHTAB (1) WDTHTAB (2) ... WDTHTAB (NSTRPTS)

See Item 4, Part 4f for variable definitions. 


\section{If Ground-Water Transport (GWT) Process is active (Ftype "GWT" exists), then read Part $4 \mathrm{~g}$ NSOL times (where NSOL is the number of solutes being simulated):}

\section{6f. Data: $\{$ CONCQ (NSOL) $\}$ CONCRUN (NSOL) CONCPPT (NSOL)}

See Item 4, Part 4g for variable definitions.

Note 17: Item 6 must be completed ITMP times. The data need not be defined in sequential order by stream segment number. All active segments in the stream network must be defined for each stress period through a combination of ITMP and Item 6 and NP and Item 7.

Note 18: If ITMP $\leq 0$, then Item 6 is excluded for this stress period. If ITMP $<0$, then values for Item 6 from the previous stress period are reused. If ITMP $=0$, then no Item 6 records are read, and all segments must be defined using parameters.

Note 19: If Item 6, Part 6f is included because solute transport is being simulated, then Part $6 \mathrm{f}$ should consist of one record (line) for each solute; each record must contain two or three values; and there must be as many records as the number of solutes being simulated (NSOL). The default value of NSOL is 1 and the presently documented version of MODFLOW-GWT is limited to simulating one solute.

Note 20: All the explanatory notes applicable to Item 4 (except those related to parameters) are also relevant to Item 6.

\section{If NP > 0, then:}

\section{Data: Pname [Iname]}

Pname The name of a parameter that is being used in the current stress period. Repeat Item 7 NP times (see Item 5).

Iname An instance name that is read only if Pname is a time-varying parameter. Multiple instances of the same time-varying parameter are not allowed in a stress period. 


\section{Stream Gaging (Monitoring) Station File (GAGE)}

Cells of the model grid can be designated as "stream gaging station" locations. At each such cell (or stream reach), the time, stage, streamflow out of that reach, and (if solute transport is being simulated) the concentration of a solute after each time step (and each transport time increment) will be written to a separate output file to facilitate model output evaluation and graphical post processing of the calculated data. Several options are available to also print additional information. The input file for specifying gaging station locations is read if the file type (Ftype) "GAGE” is included in the MODFLOW name file. The output file will contain two header lines that provide relevant information (the text will be contained within quotes). The GAGE Package is also applicable to lakes [see notes below and separate input instructions for gaging lakes in Merritt and Konikow (2000), and on the Internet web site listed in the Preface].

\section{FOR EACH SIMULATION, IF GAGE PACKAGE IS USED:}

1. Data: NUMGAGE

NUMGAGE Number of gaging stations.

\section{FOR EACH GAGING STATION:}

\section{Data: GAGESEG GAGERCH UNIT OUTTYPE}

GAGESEG An integer value that is the stream segment number where gage is located.

GAGERCH An integer value that is the stream reach number where gage is located.

UNIT An integer value that is the unit number of output file for this gage.

OUTTYPE An integer value that is a flag for type of expanded listing desired in output file:

0 Use standard default listing of time, stage, outflow, and solute concentration.

1 Default values plus depth, width, and flow at midpoint.

2 Default values plus streambed conductance for the reach, head difference across streambed, and hydraulic gradient across streambed.

3 Default values plus solute load in stream (if GWT is active).

4 All of the above.

5 Use for diversions to provide a listing of time, stage, flow diverted, maximum assigned diversion rate, flow at end of upstream segment prior to diversion, solute concentration, and solute load. 
Note 1: A unique unit number must be specified for each stream gaging station and match those unit numbers to Ftype "DATA" file types and file names in the MODFLOW name file (see Harbaugh and others, 2000, p. 42-44).

Note 2: If the LAK3 Package is also active, a gaging station may be placed on a lake. In this case, only two required variables and one optional variable are read. The first variable should be the negative value of the lake number and the second is the unit number for the output. The original description of the Gage Package (Merritt and Konikow, 2000, p. 57) did not include additional print options listed for OUTTYPE. For a gaging station on a lake, a minus sign on the unit number is a flag indicating that OUTTYPE for a lake will be read.

Note 3: Data Set 2 must include exactly NUMGAGE lines (records) of data. If NUMGAGE $>1$, it is permissible to interleaf in Item 2 records for stream gaging stations with records for gages on lakes. Data lines (records) within Item 2 can be listed in any arbitrary order.

Note 4: Solute load represents the total mass of solute passing the gaging station during a model time unit. Units for solute load depend on the units used for solute concentration, time, and length in the model. 



\section{APPENDIX 2: SELECTED INPUT DATA AND PRINTED RESULTS FOR TEST SIMULATION 1}

Test simulation 1 is designed to demonstrate the capability of the Streamflow-Routing (SFR1) Package for estimating effects of ground-water withdrawals on streamflows in an alluvial basin. This test includes two simulations: a steady-state simulation followed by a transient simulation with two stress periods - each 50 years long. For the transient simulation, the first stress period included ground-water withdrawals at twice the steady-state inflow into the aquifer and the second stress period included no ground-water withdrawals. A description of the basinfill aquifer including its extent, thickness, hydraulic properties, and model grid are presented in figures 6 and 7. Variables used to route flow in streams are presented in tables 1 and 2, and figure 9. Results of the steady-state simulation used as initial conditions for the transient simulation are presented in table 3 and figure 8 . Results of the transient simulation are presented in table 3, and figures 10-12.

Selected sections of several key input and output data files are shown below-sometimes with annotations; gaps in the listings are indicated by an ellipsis. A complete set of these files is available for distribution over the Internet as discussed in the Preface. Contents of some files are enclosed in a border and explanations are noted outside of the border; for other files, explanations are sometimes included as comments following a semi-colon on the line being explained. Some brief annotations were added to the selected output listings to help the reader understand the purpose of various sections of output. These annotations are written in bold italics. Font sizes in the following listings are sometimes reduced so that lines will fit within page margins. Information pertaining specifically to the SFR1 Package is highlighted by shading. 


\section{Listing of Selected Input Data Sets for Test Simulation 1}

Following (enclosed in a border) are the contents of the MODFLOW name file for the transient part of test simulation 1; explanations are noted outside of border:

File name: Test1tr.nam

\begin{tabular}{|c|c|c|c|}
\hline LIST & & test1tr.lst & $\leftarrow$ Output file for MODFLOW \\
\hline BAS6 & 75 & test1tr.ba6 & $\leftarrow$ Input file for Basic Package \\
\hline LPF & 7 & testltr.lpf & $\leftarrow$ Input file for Layer Property Flow Package \\
\hline DIS & 8 & testltr.dis & $\leftarrow$ Input file for Discretization Package \\
\hline SIP & 13 & test1tr.sip & $\leftarrow$ Input file for Strongly Implicit Procedure \\
\hline OC & 14 & test1tr.oc & $\leftarrow$ Input file for Output Control option \\
\hline SFR & 15 & test1.sfr & $\leftarrow$ Input file for Streamflow-Routing (SFR1) \\
\hline WEL & 16 & test1.wel & $\leftarrow$ Input file for Well Package \\
\hline GHB & 17 & test1.ghb & $\leftarrow$ Input file for General-Head Boundary Package \\
\hline EVT & 18 & test1.evt & $\leftarrow$ Input file for Evapotranspiration Package \\
\hline $\mathrm{RCH}$ & 19 & test1.rch & $\leftarrow$ Input file for Recharge Package \\
\hline GAGE & 32 & test1.gag & $\leftarrow$ Input file for Gage Package \\
\hline DATA & 58 & testltr.hds & $\leftarrow$ Output file for calculated heads \\
\hline DATA & 59 & testltr.et & $\leftarrow$ Output file for calculated heads \\
\hline DATA & 81 & testltr.flw & $\leftarrow$ Auxiliary output file for the SFR1 Package \\
\hline DATA & 83 & test1tr.sg1 & $\leftarrow$ Output file for last reach in stream segment 1 \\
\hline DATA & 84 & test1tr.sg2 & $\leftarrow$ Output file for last reach in stream segment 2 \\
\hline DATA & 85 & testitr.sg3 & $\leftarrow$ Output file for last reach in stream segment 3 \\
\hline DATA & 86 & test1tr.sg4 & $\leftarrow$ Output file for last reach in stream segment 4 \\
\hline DATA & & test1tr.sg5 & $\leftarrow$ Output file for last reach in stream segment 5 \\
\hline DATA & & testitr.sg6 & $\leftarrow$ Output file for last reach in stream segment 6 \\
\hline DATA & & testltr.sg7 & $\leftarrow$ Output file for last reach in stream segment 7 \\
\hline DATA & & test1tr.sg8 & $\leftarrow$ Output file for last reach in stream segment 8 \\
\hline DATA & 91 & test1tr.dvsg9 & $\leftarrow$ Output file for first reach of diversion segment 3 \\
\hline$\uparrow$ & $\uparrow$ & $\uparrow$ & \\
\hline 1 & 2 & 3 & \\
\hline \multicolumn{4}{|c|}{${ }^{1}$ Ftype (that is, the type of file) } \\
\hline \multicolumn{4}{|c|}{2 Unit number } \\
\hline \multicolumn{4}{|c|}{3 File name (name chosen to reflect contents of file) } \\
\hline
\end{tabular}


Following (enclosed in a border) are the contents of the Basic Package input file for the transient part of test simulation 1; explanations are noted outside of border:

File name: test1tr.ba6

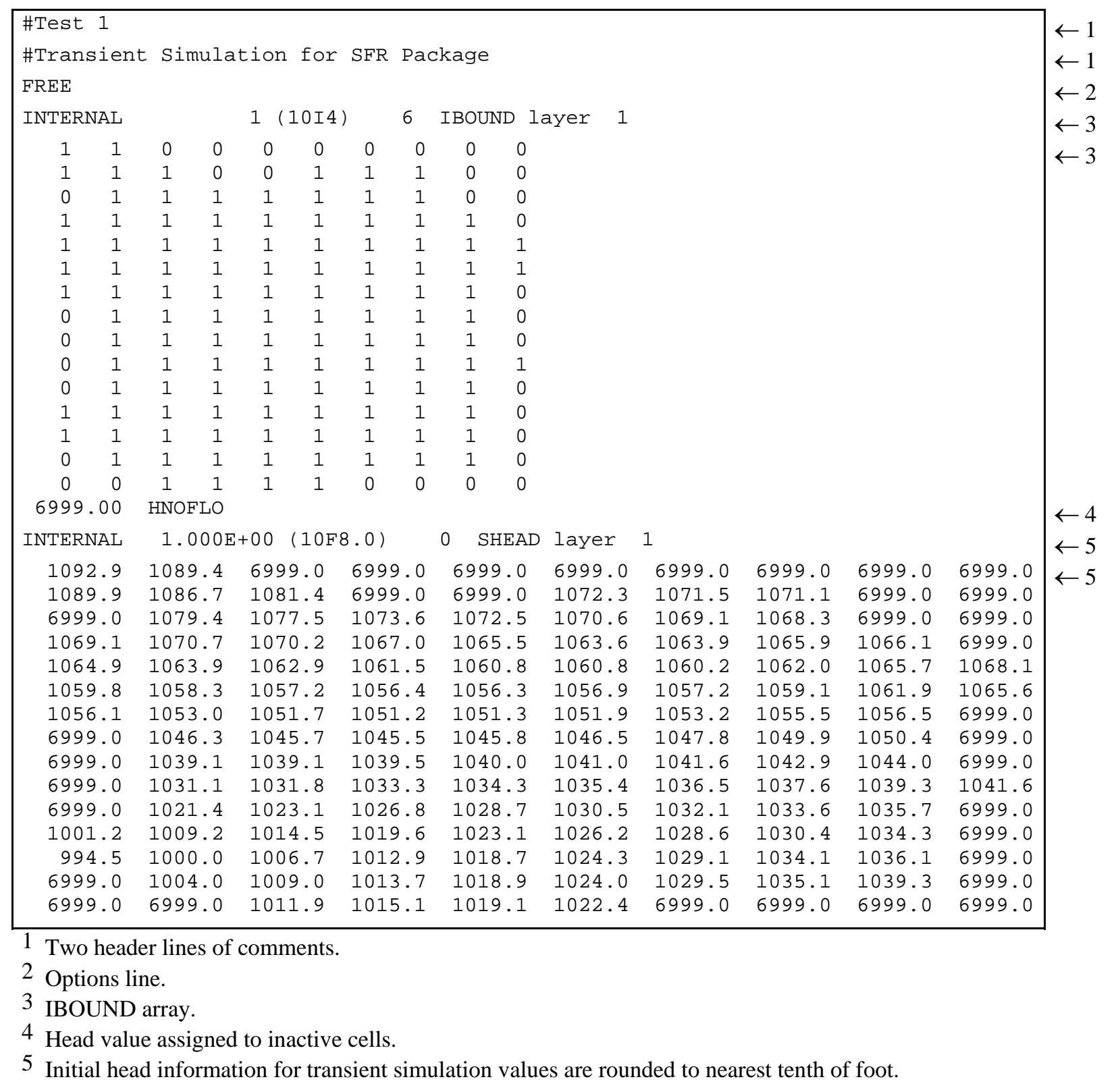


Following (enclosed in a border) are the contents of the Discretization Package input file for the transient part of test simulation 1; explanations are noted outside of border:

File name: test1tr.dis

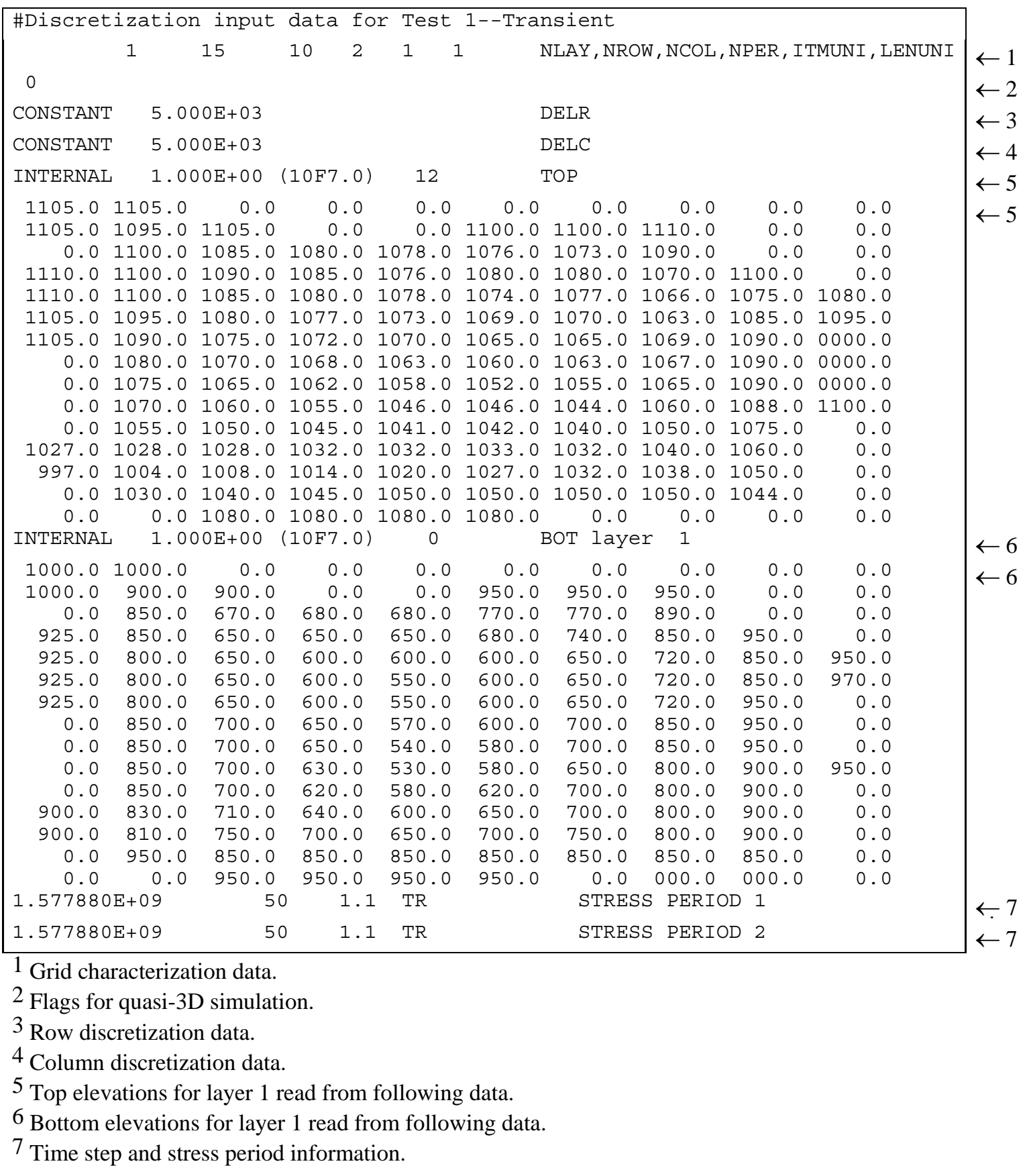


Following (enclosed in a border) are the contents of the Layer-Property Flow Package input file for the transient part of test simulation 1; explanations are noted outside of border:

File name: testltr.lpf

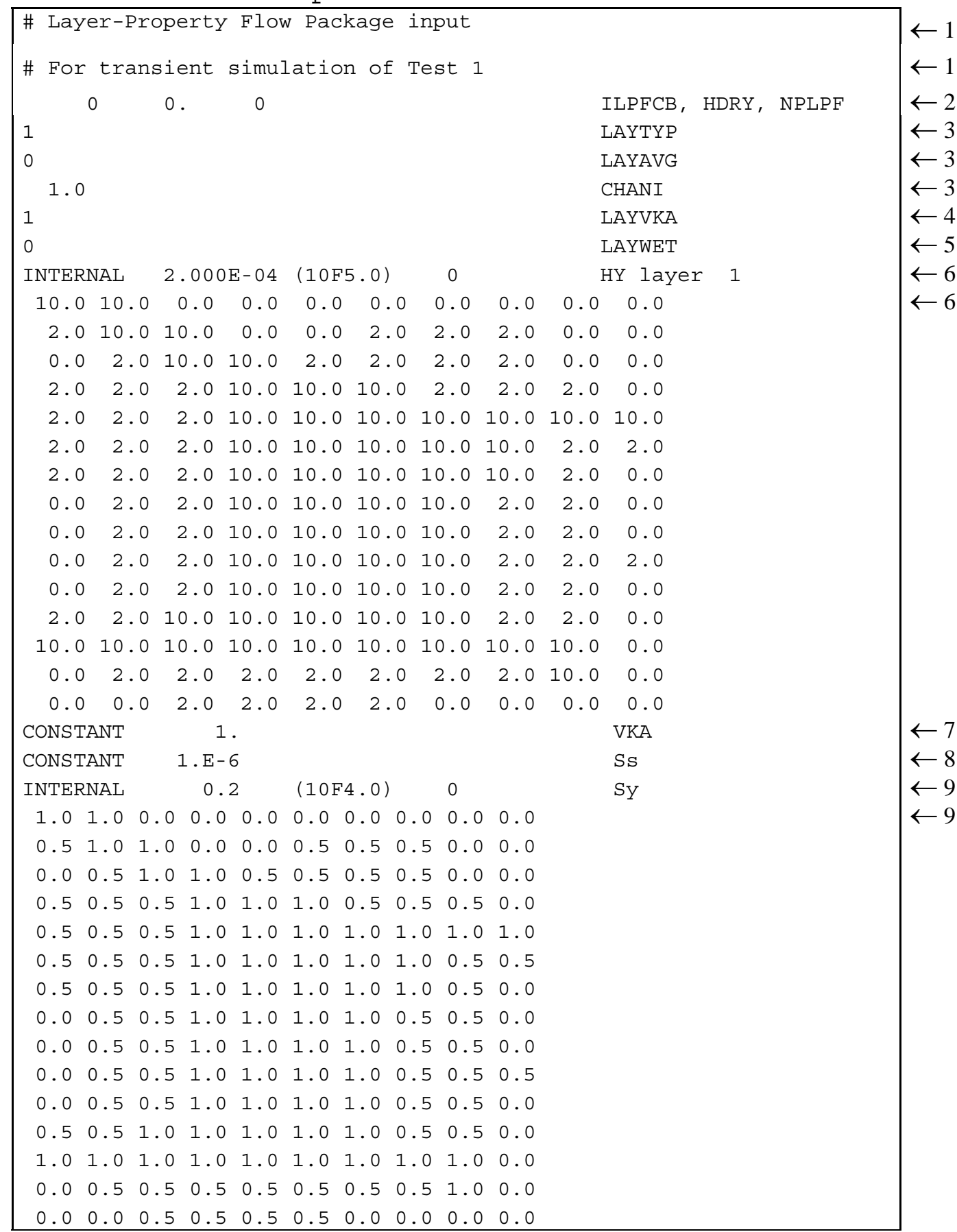

1 Comment lines.

2 Flag for cell-by-cell flow terms, head in cell for wet-dry simulations, and flag related to wet-dry simulations.

3 Layer type, method for computing transmissivity, horizontal anisotropy.

4 Flag to determine vertical hydraulic conductivity.

5 Flag to determine if rewetting is active. 


\section{A new Streamflow-Routing (SFR1) Package}

6 Hydraulic conductivity data for layer 1 read from following data.

${ }^{7}$ Ratio of vertical to horizontal hydraulic conductivity.

8 Specific storage for layer 1.

9 Specific yield for layer 1 .

Following (enclosed in a border) are the contents of the Evapotranspiration Package input file for transient part of test simulation 1; explanations are noted outside of border:

File name: test 1. evt

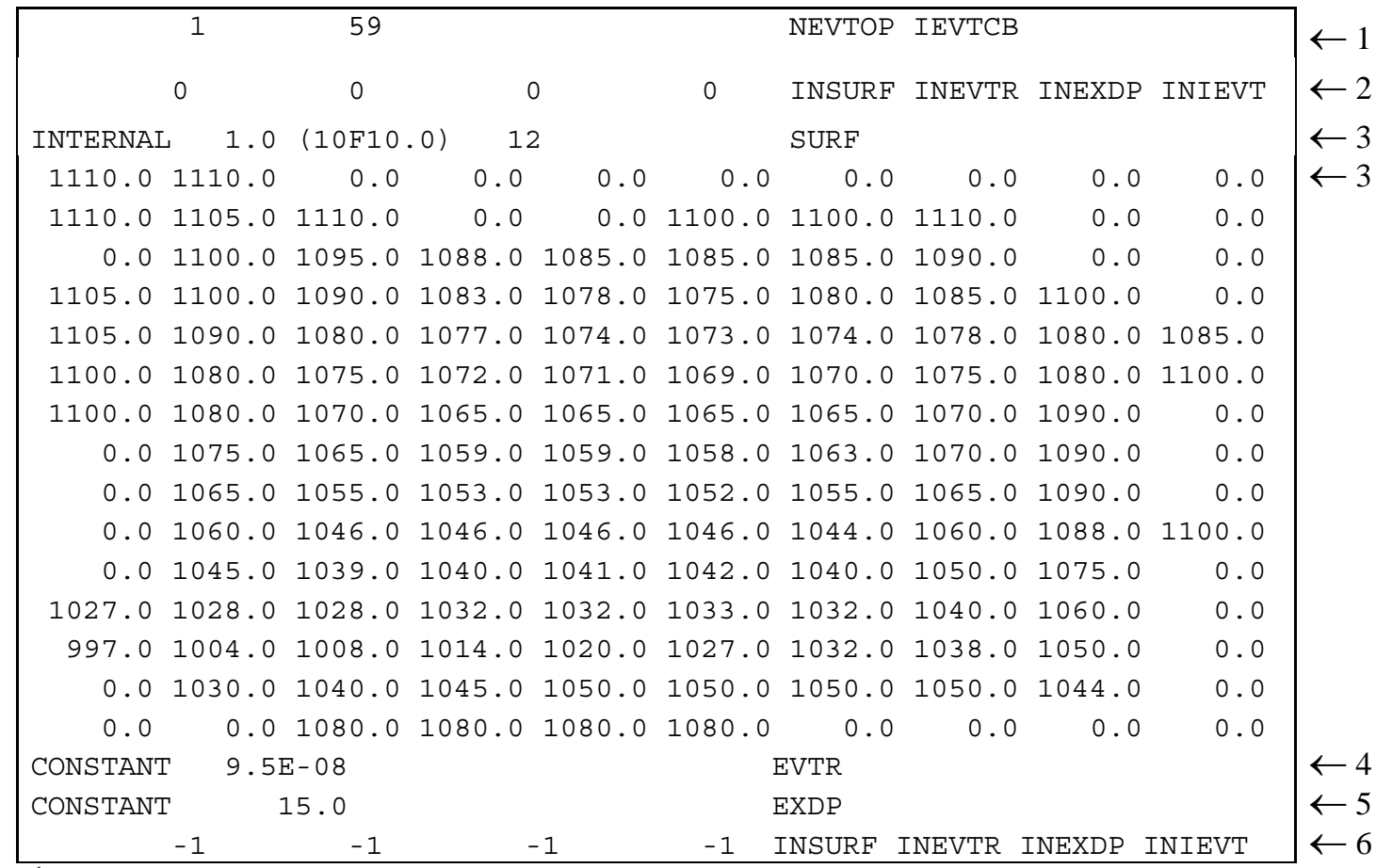

${ }^{1}$ Evapotranspiration (ET) option code and unit number for storing cell-by-cell flow terms.

2 Read flags for stress period 1.

3 ET surface elevation for stress period 1.

4 Maximum ET flux for stress period 1.

5 ET extinction depth for stress period 1.

6 Read flags for stress period 2 (reusing data from stress period 1). 
Following (enclosed in a border) are the contents of the Recharge Package input file for the transient part of test simulation 1; explanations are noted outside of border:

File name: test $1 . r c h$

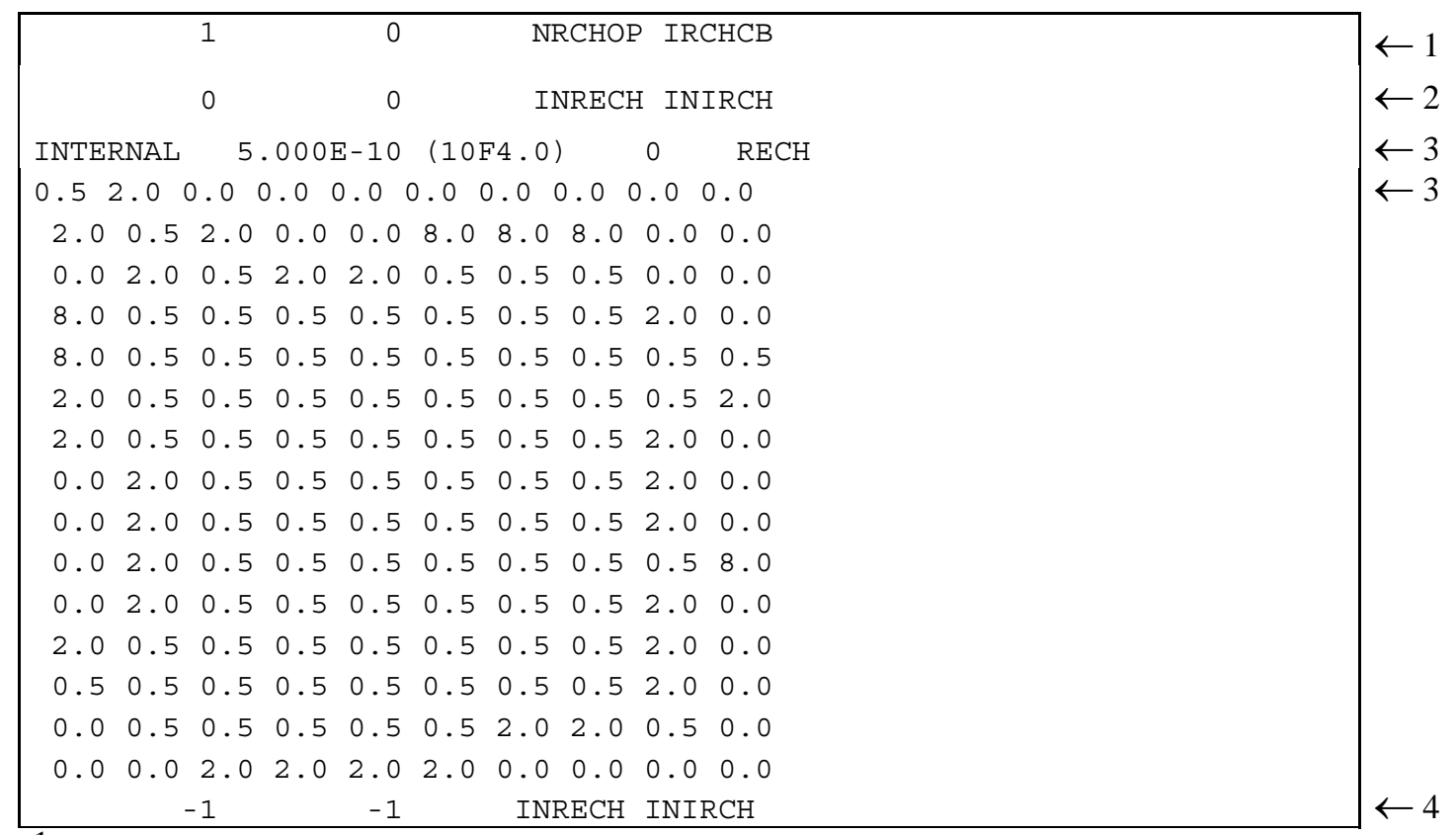

${ }^{1}$ Recharge (RCH) option code and unit number for storing cell-by-cell flow terms.

2 Read flags for stress period 1.

$3 \mathrm{RCH}$ rates for stress period 1 .

${ }^{4}$ Read flags for stress period 2 (reusing information from stress period 1).

Following (enclosed in a border) are the contents of the Well Package input file for the transient part of test simulation 1; explanations are noted outside of border:

File name: test 1. wel

\begin{tabular}{|c|c|c|c|c|c|c|c|}
\hline 10 & \multicolumn{2}{|c|}{-1} & \multicolumn{4}{|c|}{ MXACTW IWELCB } & $\leftarrow 1$ \\
\hline \multirow[t]{11}{*}{10} & & & ITMP & NP - - Stress & Period & 1 & $\leftarrow 2$ \\
\hline & 1 & 6 & 4 & -10.00 & & & $\leftarrow 3$ \\
\hline & 1 & 6 & 5 & -10.00 & & & \\
\hline & 1 & 7 & 4 & -10.00 & & & \\
\hline & 1 & 7 & 5 & -10.00 & & & \\
\hline & 1 & 8 & 4 & -10.00 & & & \\
\hline & 1 & 8 & 5 & -10.00 & & & \\
\hline & 1 & 9 & 4 & -10.00 & & & \\
\hline & 1 & 9 & 5 & -10.00 & & & \\
\hline & 1 & 10 & 4 & -10.00 & & & \\
\hline & 1 & 10 & 5 & -10.00 & & & \\
\hline 0 & & & ITMP & NP - - Stress & Period & 2 & $\leftarrow 4$ \\
\hline
\end{tabular}

1 Maximum number of wells and unit number for storing cell-by-cell flow terms.

2 Read flags for stress period 1.

3 Layer, row, column and discharge of each well for stress period 1.

4 Read flags for stress period 2 (no wells active in stress period 2). 
Following (enclosed in a border) are the contents of the General-Head Boundary Package input file for the transient part of test simulation 1; explanations are noted outside of border:

File name: test $1 . g h b$

\begin{tabular}{|c|c|c|c|c|c|c|}
\hline 2 & -1 & \multicolumn{4}{|c|}{ MXACTB IGHBCB } & $\leftarrow 1$ \\
\hline 2 & 0 & & MP NP - & - Stress Period & 1 & $\leftarrow 2$ \\
\hline 1 & 13 & 1 & 988.0 & 0.038 & & $\leftarrow 3$ \\
\hline 1 & 14 & 9 & 1045.0 & 0.038 & & \\
\hline-1 & 0 & & MP NP & -- Stress Period & 2 & $\leftarrow 4$ \\
\hline
\end{tabular}

1 Maximum number of general-head boundary cells and unit number for storing cell-by-cell flow terms.

2 Read flags for stress period 1.

3 General-head boundary cells for stress period 1 .

${ }^{4}$ Read flags for stress period 2 (reusing information from stress period 1 ).

Following (enclosed in a border) are the contents of the Strongly Implicit Procedure Package input file for the transient part of test simulation 1; explanations are noted outside of border:

File name: test1tr.sip

\begin{tabular}{|c|c|c|c|c|c|}
\hline 300 & 5 & \multicolumn{3}{|c|}{ MXITER NPARM } & $\leftarrow 1$ \\
\hline 0.80 & 1.0E-03 & 1 & 0.0 & 1 & \\
\hline
\end{tabular}

1 Maximum iterations, number of iteration parameters.

2 Acceleration parameter, head change criterion, flag for seed, seed, printout interval for SIP.

Following (enclosed in a border) are the contents of the Streamflow-Routing (SFR1) Package input file for the transient part of test simulation 1; explanations are noted outside of border:

File name: Test $1 . \operatorname{sfr}$

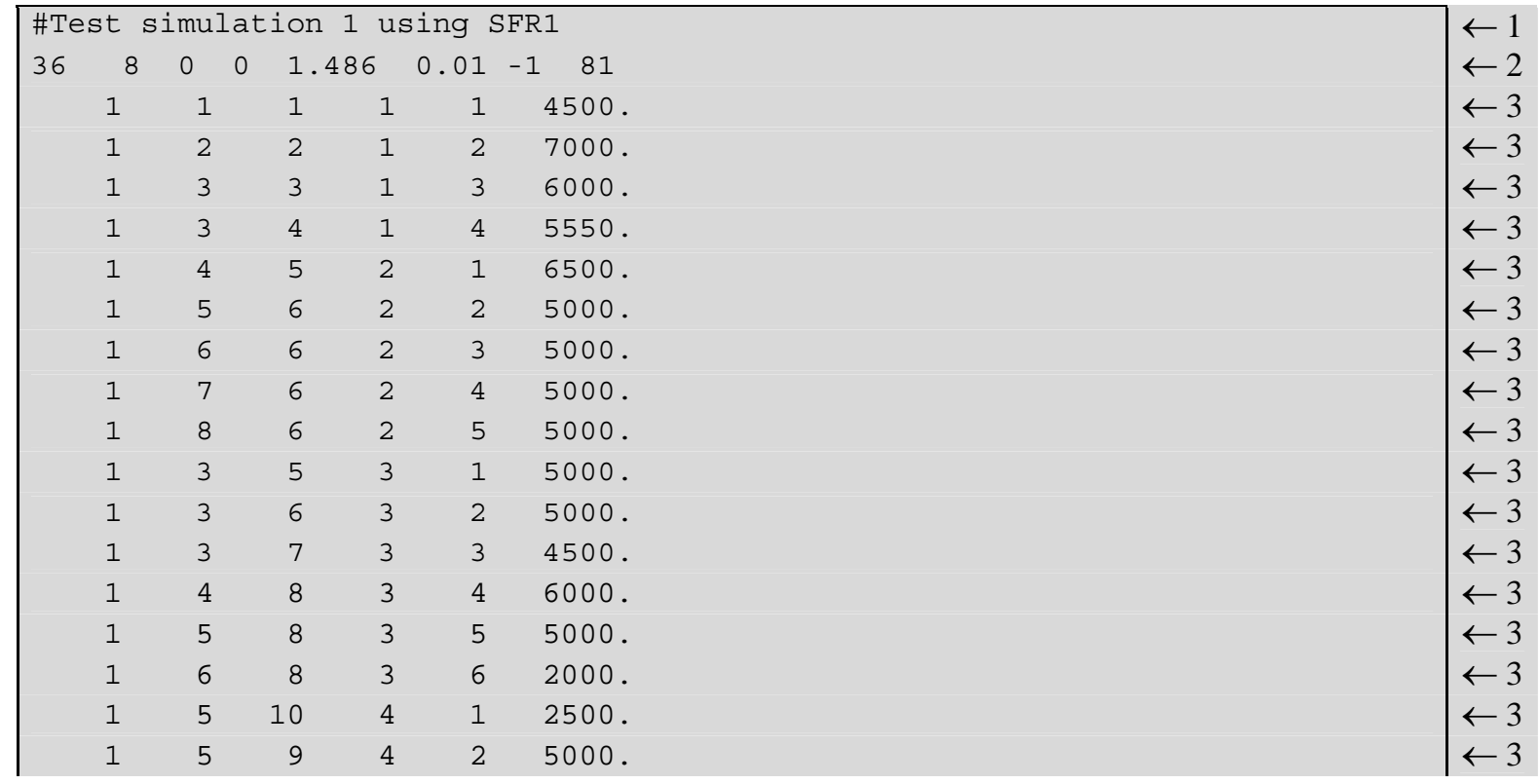




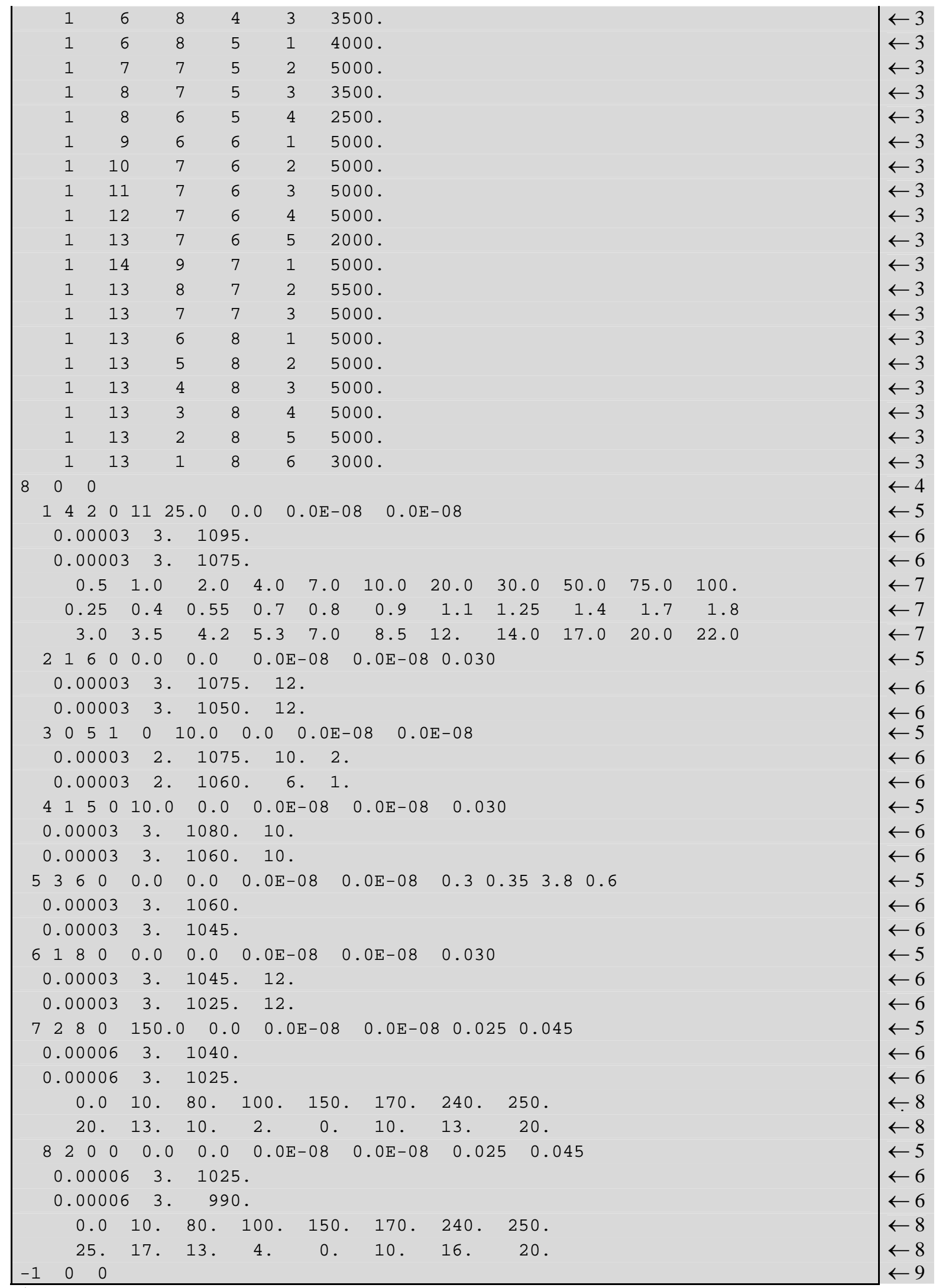

${ }^{1}$ Optional text line for comments. 


\section{A new Streamflow-Routing (SFR1) Package}

2 Basic stream network description (Input Item 1).

3 Stream reach descriptions (Input Item 2).

${ }^{4}$ Read and print flags for stress period 1(Input Item 5).

5 General stream segment data (Input item 6a).

6 Stream segment data for upstream and downstream ends (Input Items 6b \& 6c).

7 Stream segment data when relation of flow to depth and width read from table (Input Item 6e).

8 Stream segment data for 8-point cross section (Input Item 6d).

${ }^{9}$ Read and print flags for stress period 2 (reusing information from stress period 1; Input Item 5).

Following (enclosed in a border) are the contents of the Output-Control option input file for the transient part of test simulation 1. Input was constructed in the optional style using words:

File name: testitr.oc

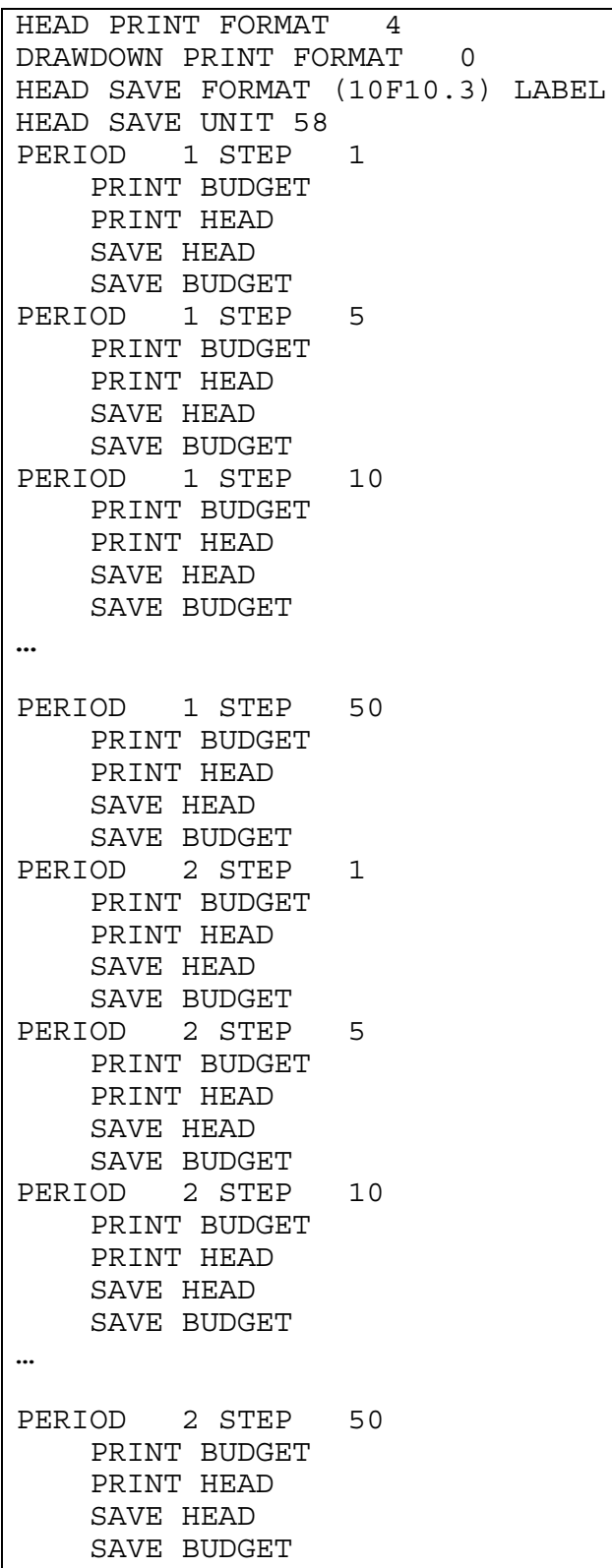


Following are the contents of the Gage package input file for the transient part of test simulation 1; explanations are noted as comments at the end of each record (Unit numbers are linked to a file name through the Ftype "DATA" in the MODFLOW name file):

File name: test 1. gag

\begin{tabular}{|llllllll}
\hline 8 & \multicolumn{7}{c|}{ NUMGAGE (number of gaging stations) } \\
1 & 4 & 83 & 4 & Stream Segment \& Reach \#; Output file for Gage 1; Output option \\
2 & 3 & 84 & 1 & Stream Segment \& Reach \#; Output file for Gage 2; Output option \\
3 & 6 & 85 & 1 & Stream Segment \& Reach \#; Output file for Gage 3; Output option \\
4 & 3 & 86 & 1 & Stream Segment \& Reach \#; Output file for Gage 4; Output option \\
5 & 4 & 87 & 4 & Stream Segment \& Reach \#; Output file for Gage 5; Output option \\
6 & 5 & 88 & 1 & Stream Segment \& Reach \#; Output file for Gage 6; Output option \\
7 & 3 & 89 & 4 & Stream Segment \& Reach \#; Output file for Gage 7; Output option \\
8 & 6 & 90 & 4 & Stream Segment \& Reach \#; Output file for Gage 8; Output option \\
3 & 1 & 91 & 5 & Stream Segment \& Reach \#; Output file for Gage 9; Output option \\
\hline
\end{tabular}




\section{Listing of Selected Output Files for Test Simulation 1}

Following are the contents of the main MODFLOW listing file of the transient part for test simulation 1:

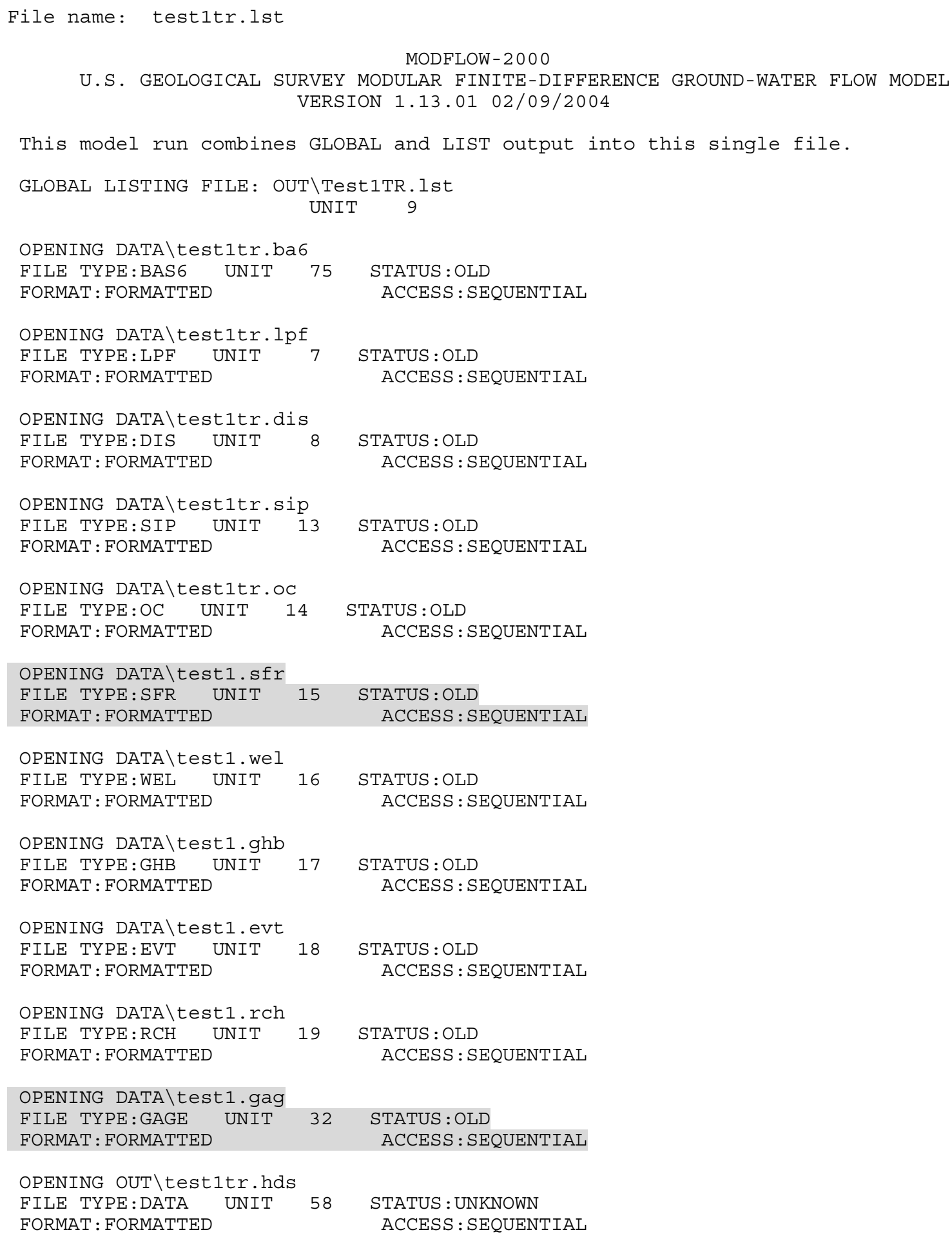




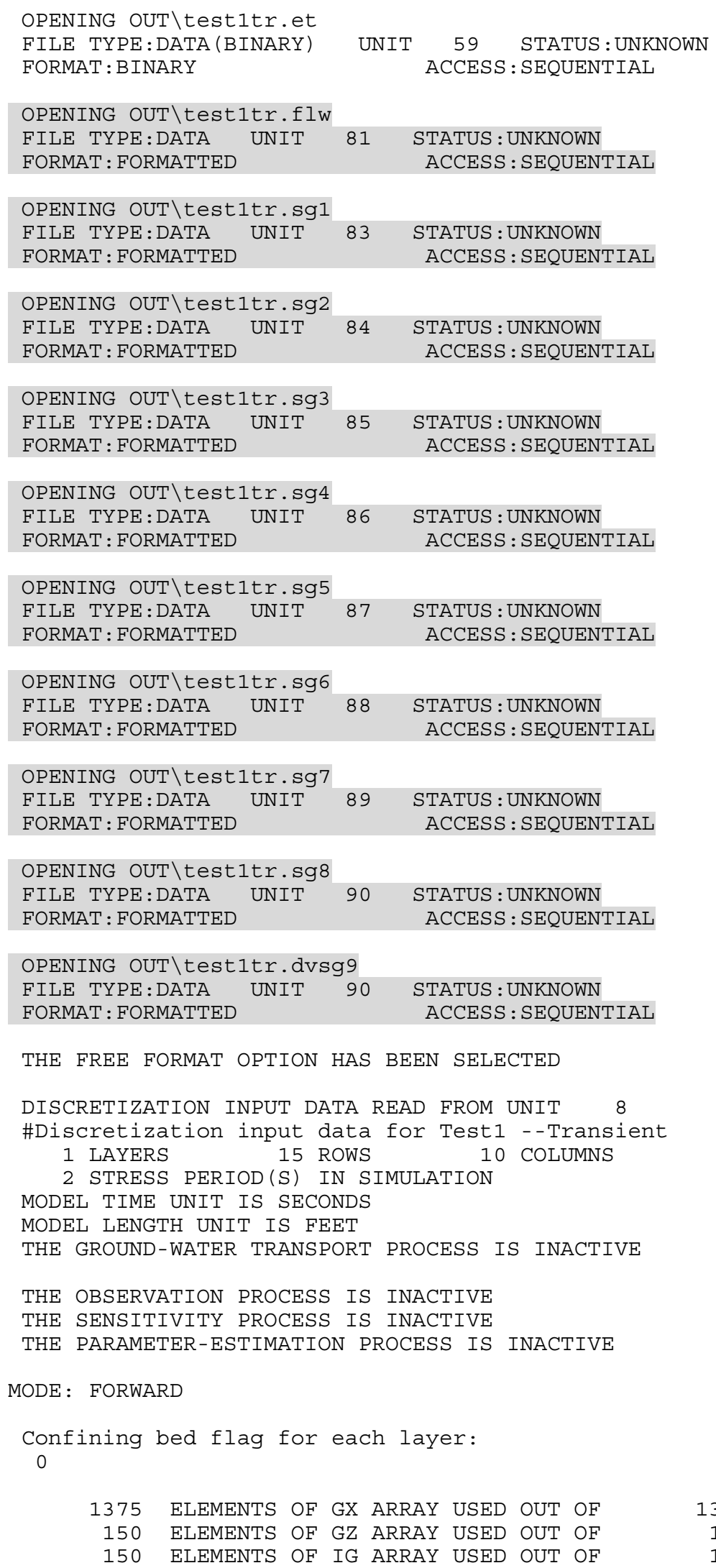




\section{A new Streamflow-Routing (SFR1) Package}

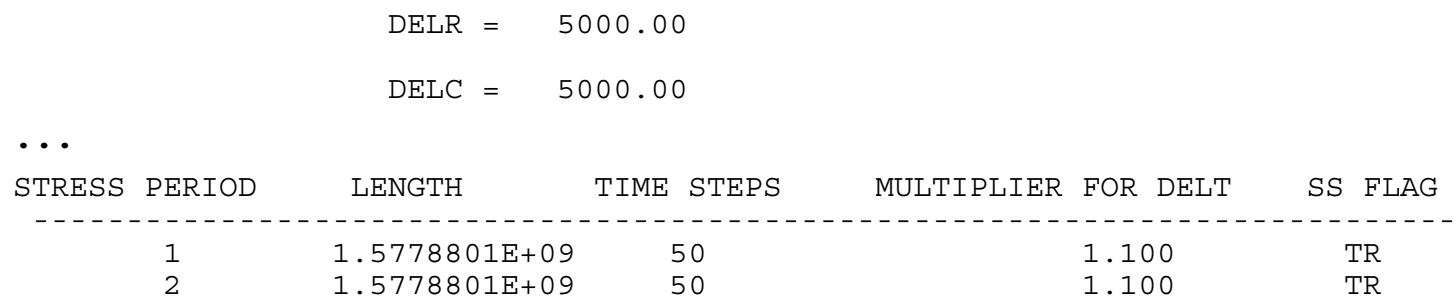

TRANSIENT SIMULATION

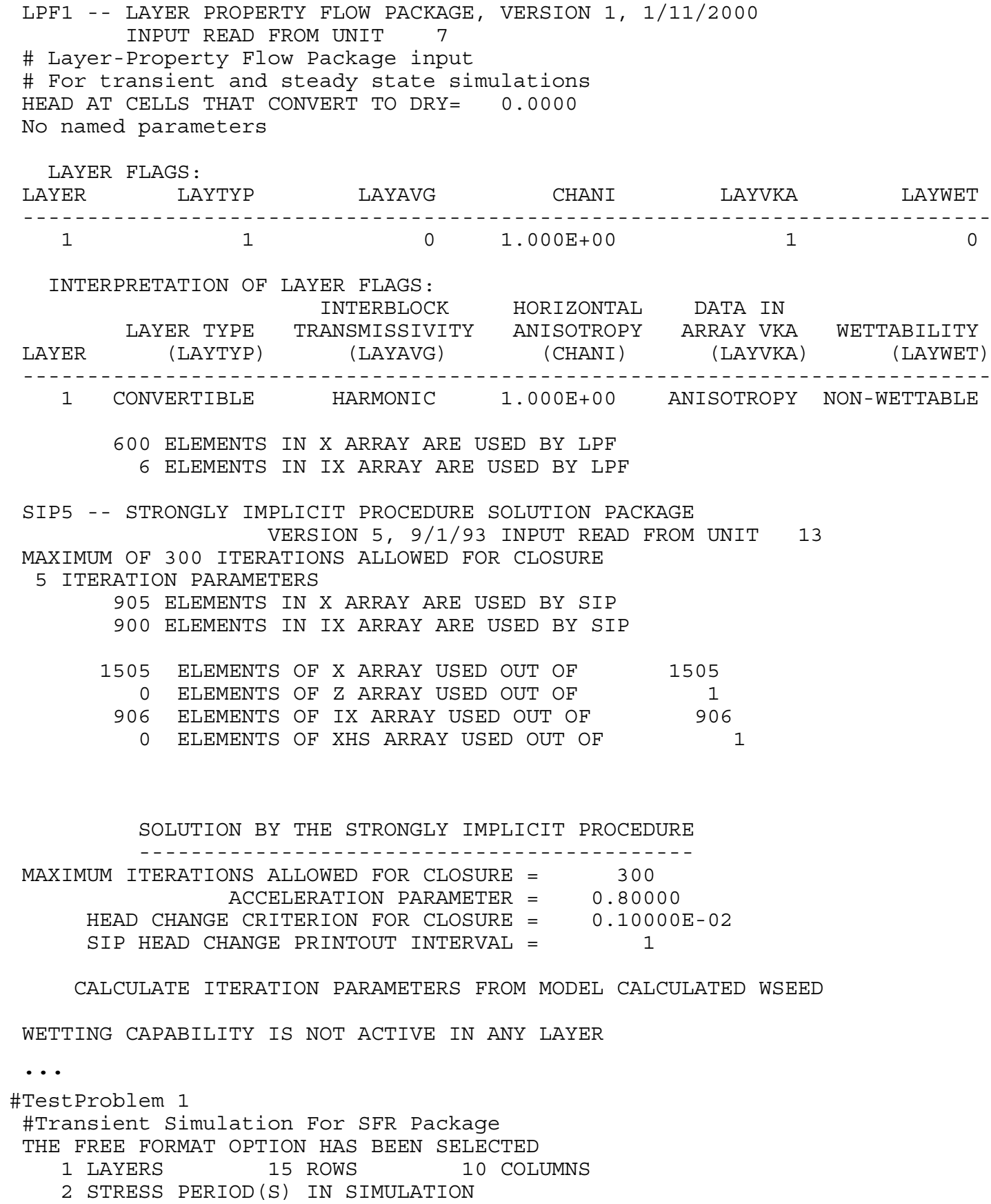




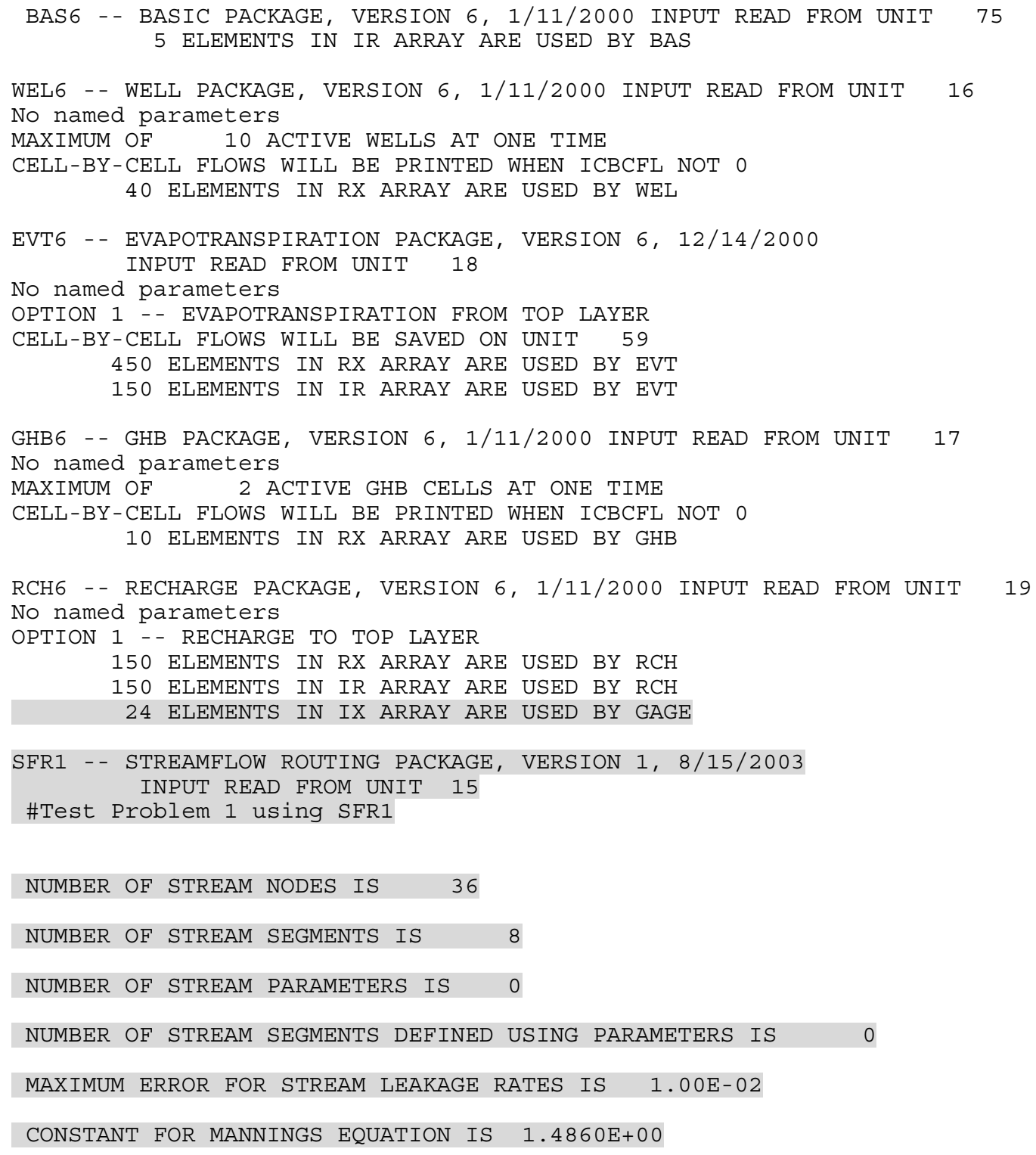

\begin{tabular}{|c|c|c|c|c|c|}
\hline LAYER & ROW & $\mathrm{COL}$ & $\begin{array}{c}\text { SEGMENT } \\
\text { NUMBER }\end{array}$ & $\begin{array}{l}\text { REACH } \\
\text { NUMBER }\end{array}$ & $\begin{array}{l}\text { LENGTH } \\
\text { IN CELL }\end{array}$ \\
\hline & & & & & 450 \\
\hline$\perp$ & $\frac{1}{2}$ & $\begin{array}{l}1 \\
2\end{array}$ & $\begin{array}{l}1 \\
1\end{array}$ & $\frac{1}{2}$ & 7.000 \\
\hline 1 & 3 & 3 & 1 & 3 & $6.000 \mathrm{E}+$ \\
\hline 1 & 3 & 4 & 1 & 4 & $5.550 \mathrm{E}+03$ \\
\hline 1 & 4 & 5 & 2 & 1 & $6.500 \mathrm{E}+$ \\
\hline 1 & 5 & 6 & 2 & & $5.000 \mathrm{E}$ \\
\hline
\end{tabular}




\section{A new Streamflow-Routing (SFR1) Package}

\begin{tabular}{|c|c|c|c|c|c|}
\hline 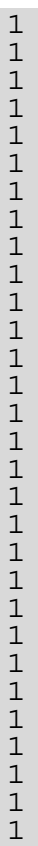 & $\begin{array}{r}6 \\
7 \\
8 \\
3 \\
3 \\
3 \\
4 \\
5 \\
6 \\
5 \\
5 \\
6 \\
6 \\
7 \\
8 \\
8 \\
9 \\
10 \\
11 \\
12 \\
13 \\
14 \\
13 \\
13 \\
13 \\
13 \\
13 \\
13 \\
13 \\
13\end{array}$ & $\begin{array}{r}6 \\
6 \\
6 \\
5 \\
6 \\
7 \\
8 \\
8 \\
8 \\
10 \\
9 \\
8 \\
8 \\
7 \\
7 \\
6 \\
6 \\
7 \\
7 \\
7 \\
7 \\
9 \\
8 \\
7 \\
6 \\
5 \\
4 \\
3 \\
2 \\
1\end{array}$ & $\begin{array}{l}2 \\
2 \\
2 \\
3 \\
3 \\
3 \\
3 \\
3 \\
3 \\
3\end{array}$ & $\begin{array}{l}3 \\
4 \\
5\end{array}$ & $\begin{array}{l}5.000 \mathrm{E}+03 \\
5.000 \mathrm{E}+03 \\
5.000 \mathrm{E}+03 \\
5.000 \mathrm{E}+03 \\
5.000 \mathrm{E}+03 \\
4.500 \mathrm{E}+03 \\
6.000 \mathrm{E}+03 \\
5.000 \mathrm{E}+03 \\
2.000 \mathrm{E}+03 \\
2.500 \mathrm{E}+03 \\
5.000 \mathrm{E}+03 \\
3.500 \mathrm{E}+03 \\
4.000 \mathrm{E}+03 \\
5.000 \mathrm{E}+03 \\
3.500 \mathrm{E}+03 \\
2.500 \mathrm{E}+03 \\
5.000 \mathrm{E}+03 \\
5.000 \mathrm{E}+03 \\
5.000 \mathrm{E}+03 \\
5.000 \mathrm{E}+03 \\
2.000 \mathrm{E}+03 \\
5.000 \mathrm{E}+03 \\
5.500 \mathrm{E}+03 \\
5.000 \mathrm{E}+03 \\
5.000 \mathrm{E}+03 \\
5.000 \mathrm{E}+03 \\
5.000 \mathrm{E}+03 \\
5.000 \mathrm{E}+03 \\
5.000 \mathrm{E}+03 \\
3.000 \mathrm{E}+03\end{array}$ \\
\hline
\end{tabular}

9 GAGING STATIONS WERE SPECIFIED.

(Lakes are identified by a negative value of the Lake Number)

RECORDS WILL BE WRITTEN TO SEPARATE OUTPUT FILES REPRESENTED BY FOLLOWING UNIT NUMBERS:

\section{Stream Gages:}

$\begin{array}{rcccc}\text { GAGE \# } & \text { SEGMENT } & \text { REACH } & \text { UNIT } & \text { OUTTYPE } \\ 1 & 1 & 4 & 83 & 4 \\ 2 & 2 & 3 & 84 & 1 \\ 3 & 3 & 6 & 85 & 1 \\ 4 & 4 & 3 & 86 & 1 \\ 5 & 5 & 4 & 87 & 4 \\ 6 & 6 & 5 & 88 & 1 \\ 7 & 7 & 3 & 89 & 4 \\ 8 & 8 & 6 & 90 & 4 \\ 9 & 3 & 1 & 91 & 5\end{array}$

CLASSIFICATION \& COUNT OF STREAM SEGMENTS BASED ON SOURCE OF INFLOW:

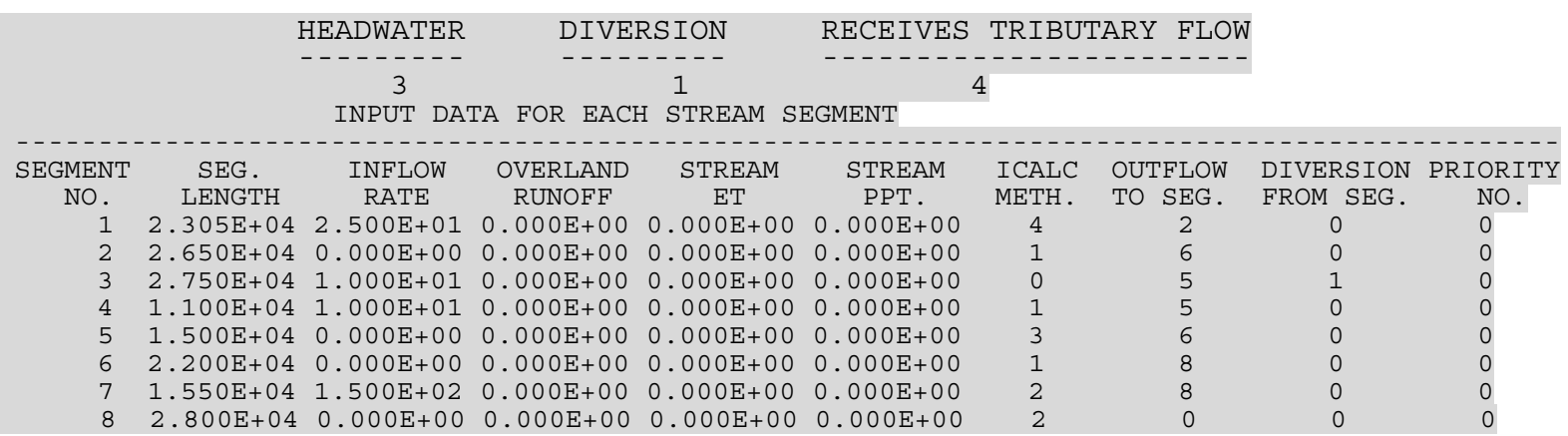


Appendix 2: Test simulation 171

STREAMBED PROPERTIES AND STREAM DIMENSIONS

SEGMENT BED HYD. COND. BED THICKNESS ELEV.-TOP OF BED WIDTH OF STREAM DEPTH OF STREAM STREAM ROUGHNES

\begin{tabular}{|c|c|c|c|c|c|c|c|c|c|c|c|c|}
\hline No. & UPPER & LOWER & UPPER & LOWER & UPPER & LOWER & UPPER & LOWER & UPPER & LOWER & CHANNEL & BANK \\
\hline 1 & $3.00 \mathrm{E}-05$ & $3.00 \mathrm{E}-05$ & $3.00 \mathrm{E}+00$ & $3.00 \mathrm{E}+00$ & $1.095 \mathrm{E}+03$ & $1.075 \mathrm{E}+03$ & & & & & & \\
\hline 2 & $3.00 \mathrm{E}-05$ & $3.00 \mathrm{E}-05$ & $3.00 \mathrm{E}+00$ & $3.00 \mathrm{E}+00$ & $1.075 \mathrm{E}+03$ & $1.050 \mathrm{E}+03$ & 1. $20 \mathrm{E}+01$ & $1.20 \mathrm{E}+01$ & & & $3.00 \mathrm{E}-02$ & \\
\hline 3 & $3.00 \mathrm{E}-05$ & $3.00 \mathrm{E}-05$ & $2.00 \mathrm{E}+00$ & $2.00 \mathrm{E}+00$ & $1.075 \mathrm{E}+03$ & $1.060 \mathrm{E}+03$ & $1.00 \mathrm{E}+01$ & $6.00 \mathrm{E}+00$ & $2.00 \mathrm{E}+00$ & $1.00 \mathrm{E}+00$ & & \\
\hline 4 & $3.00 \mathrm{E}-05$ & $3.00 \mathrm{E}-05$ & $3.00 \mathrm{E}+00$ & $3.00 \mathrm{E}+00$ & $1.080 \mathrm{E}+03$ & $1.060 \mathrm{E}+03$ & $1.000 \mathrm{E}+01$ & $1.000 \mathrm{E}+01$ & & & $3.00 \mathrm{E}-02$ & \\
\hline 5 & $3.00 \mathrm{E}-05$ & $3.00 \mathrm{E}-05$ & $3.00 \mathrm{E}+00$ & $3.00 \mathrm{E}+00$ & $1.060 \mathrm{E}+03$ & $1.045 \mathrm{E}+03$ & & & & & & \\
\hline 6 & $3.00 \mathrm{E}-05$ & $3.00 \mathrm{E}-05$ & $3.00 \mathrm{E}+00$ & $3.00 \mathrm{E}+00$ & $1.045 \mathrm{E}+03$ & $1.025 \mathrm{E}+03$ & $1.200 \mathrm{E}+01$ & $1.200 \mathrm{E}+01$ & & & $3.000 \mathrm{E}-02$ & \\
\hline 7 & $6.00 \mathrm{E}-05$ & $6.00 \mathrm{E}-05$ & $3.00 \mathrm{E}+00$ & $3.00 \mathrm{E}+00$ & $1.040 \mathrm{E}+03$ & $1.025 \mathrm{E}+03$ & & & & & $2.500 \mathrm{E}-02$ & $4.500 \mathrm{E}-02$ \\
\hline 8 & $6.00 \mathrm{E}-05$ & $6.00 \mathrm{E}-05$ & $3.00 \mathrm{E}+00$ & $3.00 \mathrm{E}+00$ & $1.025 \mathrm{E}+03$ & $9.900 \mathrm{E}+02$ & & & & & $2.500 \mathrm{E}-02$ & $4.500 \mathrm{E}-02$ \\
\hline
\end{tabular}

EIGHT POINT CROSS SECTION DATA FOR SEGMENTS WITH ICALC $=2$

$X$ VALUES $X$ VALUES START FROM LEFT SIDE LOOKING DOWNSTREAM

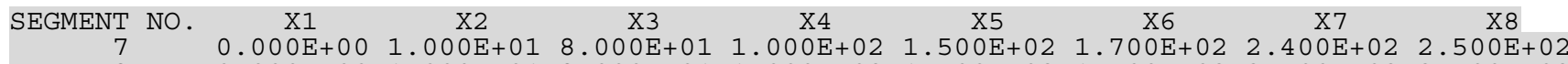
$80.000 E+001.000 E+01 \quad 8.000 E+01 \quad 1.000 E+021.500 E+02 \quad 1.700 E+02 \quad 2.400 E+02 \quad 2.500 E+02$
Z VALUES ARE RELATIVE TO STREAMBED ELEVATION

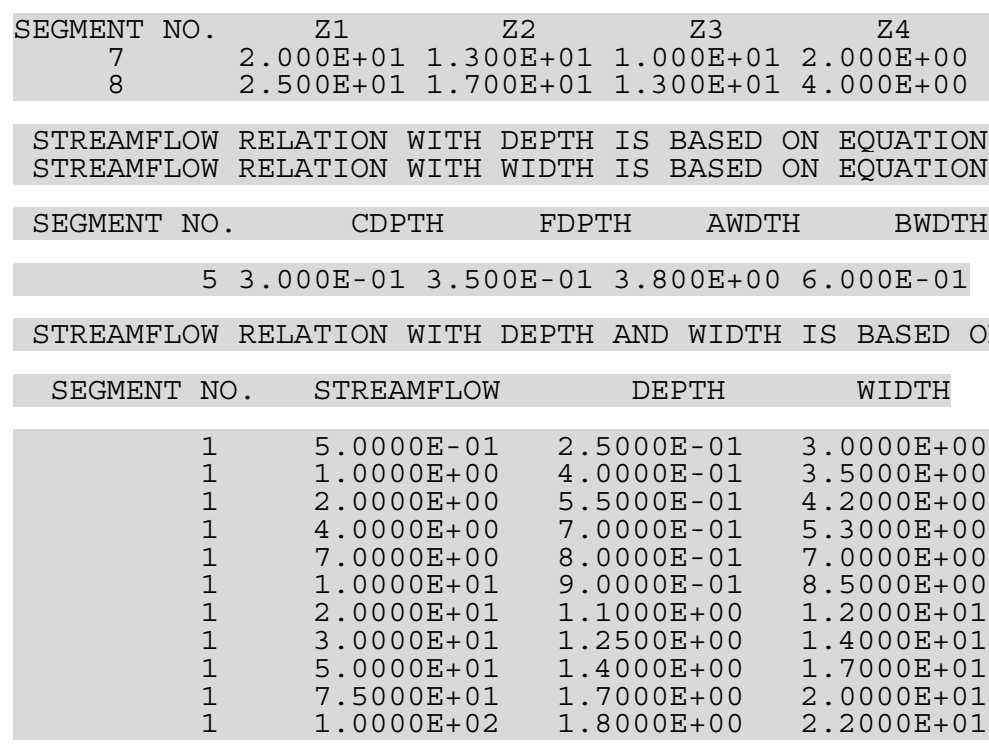

- •

SOLVING FOR HEAD

7 ITERATIONS FOR TIME STEP 13 IN STRESS PERIOD

MAXIMUM HEAD CHANGE FOR EACH ITERATION :

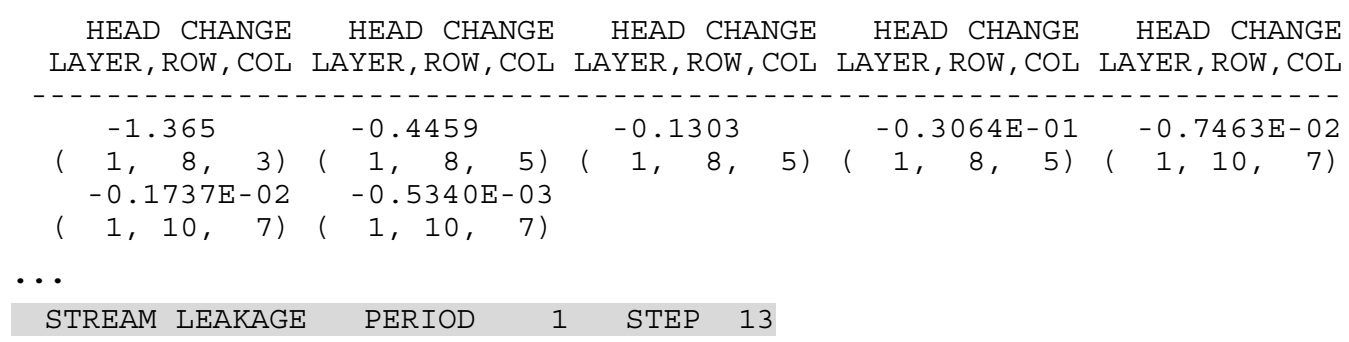

LAYER ROW COL STREAM RCH. FLOW INTO FLOW TO FLOW OUT OF OVRLND. DIRECT STREAM STREAM STREAM STREAM STREAMBED STREAMBED SEG.NO. NO. STRM. RCH. AQUIFER STRM. RCH. RUNOFF PRECIP ET HEAD DEPTH WIDTH CONDCTNC. GRADIENT

$\begin{array}{lllllllllllllllll}1 & 1 & 1 & 1 & 1 & 2.500 \mathrm{E}+01 & 8.115 \mathrm{E}-01 & 2.419 \mathrm{E}+01 & 0.00 \mathrm{E}+00 & 0.00 \mathrm{E}+00 & 0.00 \mathrm{E}+00 & 1.09 \mathrm{E}+03 & 1.17 \mathrm{E}+00 & 1.31 \mathrm{E}+01 & 5.94 \mathrm{E}-01 & 4.56 \mathrm{E}-01 \\ 1 & 2 & 2 & 1 & 2 & 2.419 \mathrm{E}+01 & 2.422 \mathrm{E}+00 & 2.177 \mathrm{E}+01 & 0.00 \mathrm{E}+00 & 0.00 \mathrm{E}+00 & 0.00 \mathrm{E}+00 & 1.09 \mathrm{E}+03 & 1.15 \mathrm{E}+00 & 1.26 \mathrm{E}+01 & 8.68 \mathrm{E}-01 & 9.30 \mathrm{E}-01 \\ 1 & 3 & 3 & 1 & 3 & 2.177 \mathrm{E}+01 & 2.888 \mathrm{E}+00 & 1.888 \mathrm{E}+01 & 0.00 \mathrm{E}+00 & 0.00 \mathrm{E}+00 & 0.00 \mathrm{E}+00 & 1.08 \mathrm{E}+03 & 1.11 \mathrm{E}+00 & 1.21 \mathrm{E}+01 & 7.03 \mathrm{E}-01 & 1.37 \mathrm{E}+00 \\ 1 & 3 & 4 & 1 & 4 & 1.888 \mathrm{E}+01 & 2.454 \mathrm{E}+00 & 1.642 \mathrm{E}+01 & 0.00 \mathrm{E}+00 & 0.00 \mathrm{E}+00 & 0.00 \mathrm{E}+00 & 1.08 \mathrm{E}+03 & 1.06 \mathrm{E}+00 & 1.13 \mathrm{E}+01 & 6.04 \mathrm{E}-01 & 1.35 \mathrm{E}+00 \\ 1 & 4 & 5 & 2 & 1 & 6.424 \mathrm{E}+00 & 2.758 \mathrm{E}+00 & 3.666 \mathrm{E}+00 & 0.00 \mathrm{E}+00 & 0.00 \mathrm{E}+00 & 0.00 \mathrm{E}+00 & 1.07 \mathrm{E}+03 & 5.36 \mathrm{E}-01 & 1.20 \mathrm{E}+01 & 7.80 \mathrm{E}-01 & 1.18 \mathrm{E}+00\end{array}$




\section{A new Streamflow-Routing (SFR1) Package}

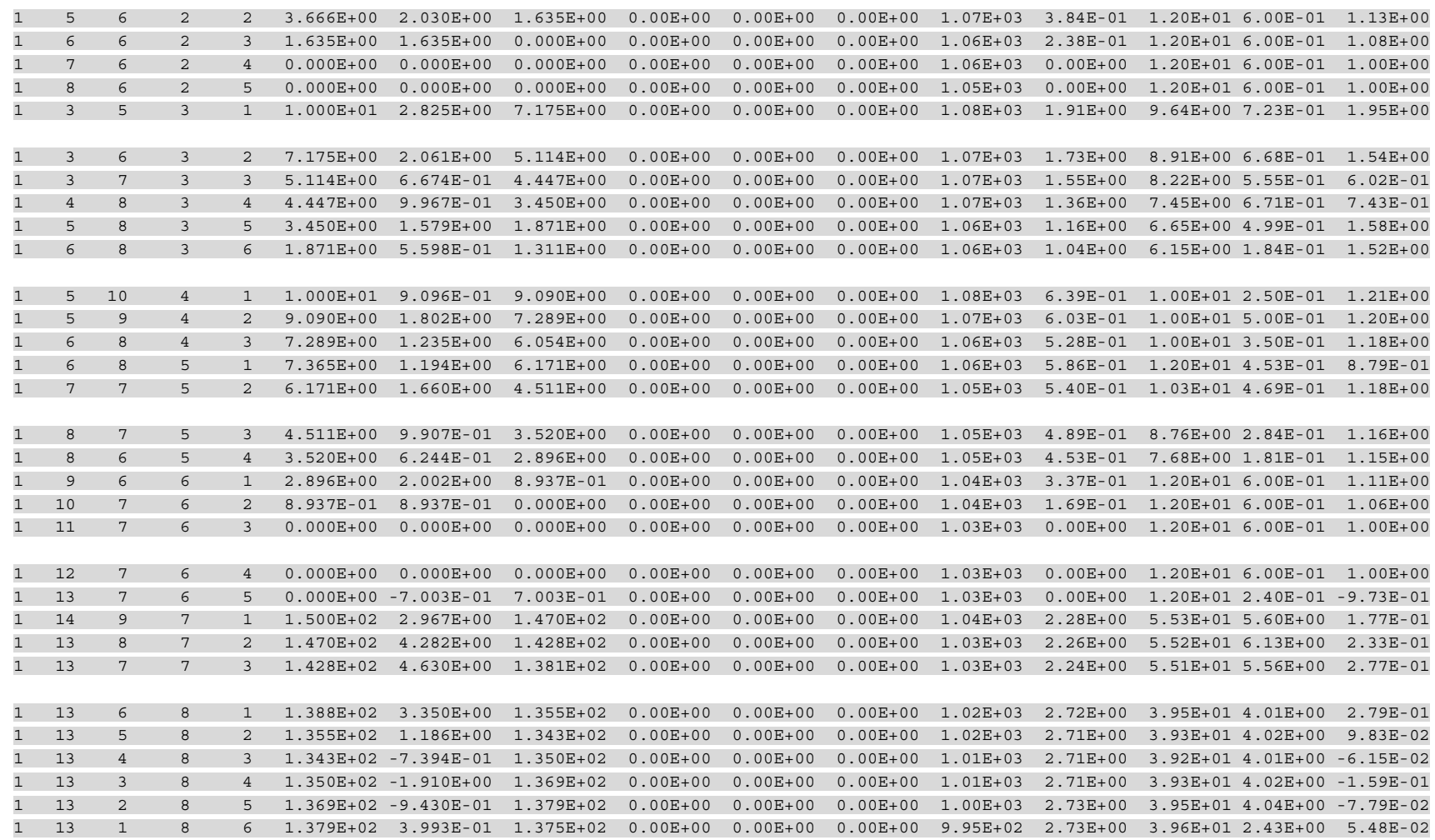

$\cdots$

VOLUMETRIC BUDGET FOR ENTIRE MODEL AT END OF TIME STEP 13 IN STRESS PERIOD 1

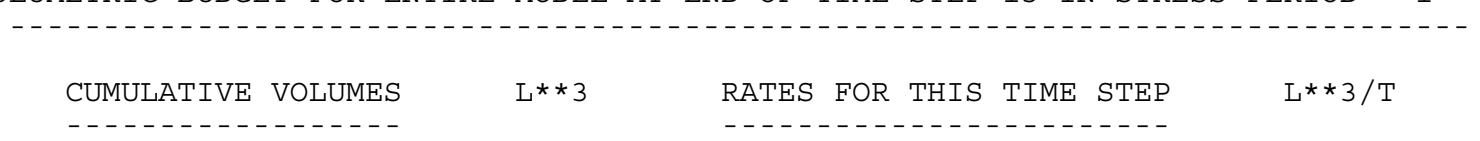

IN :

- - - - - - - - - -

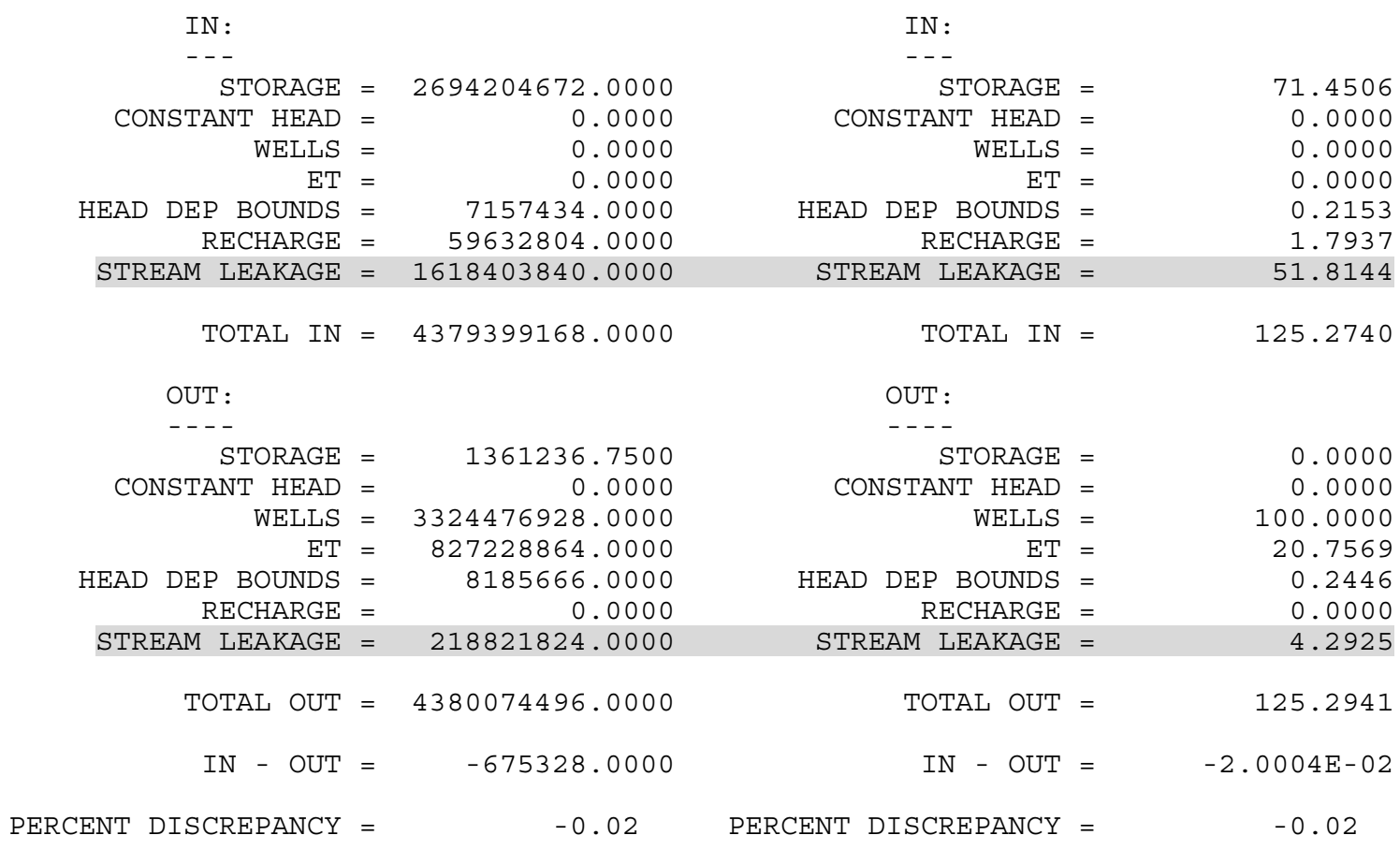


Appendix 2: Test simulation 173

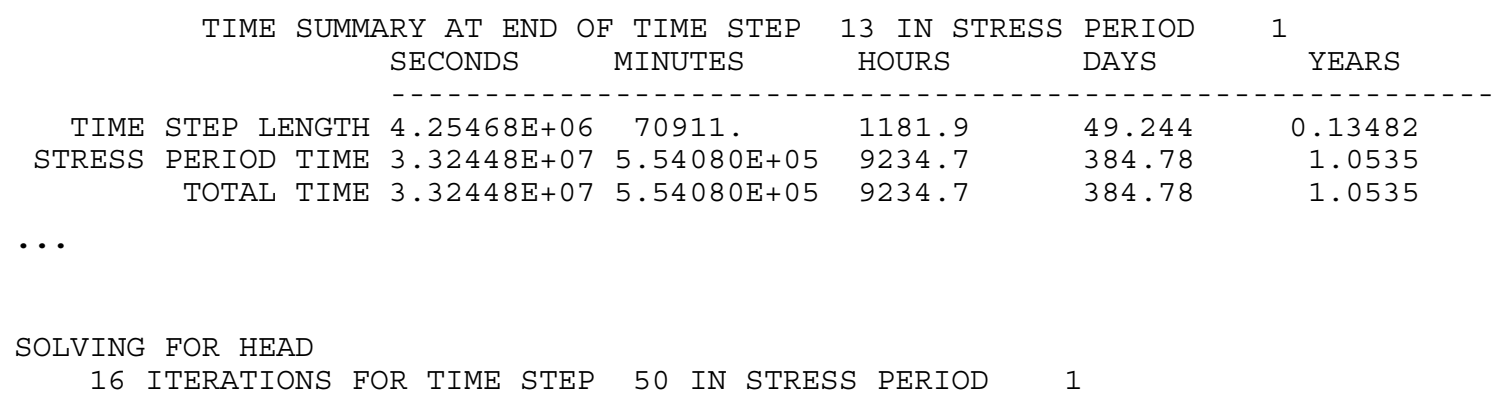

MAXIMUM HEAD CHANGE FOR EACH ITERATION:

HEAD CHANGE HEAD CHANGE HEAD CHANGE HEAD CHANGE HEAD CHANGE LAYER, ROW, COL LAYER, ROW, COL LAYER, ROW, COL LAYER, ROW, COL LAYER, ROW, COL

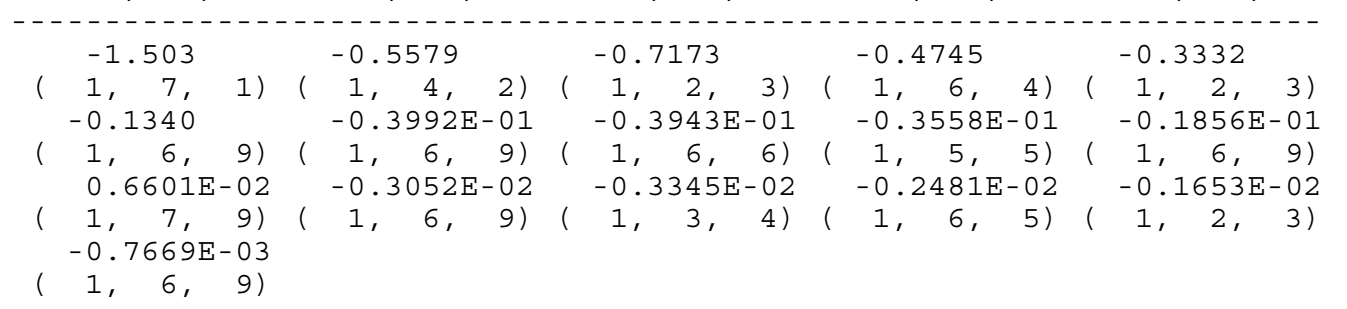

$\cdots$

$\begin{array}{lllll}\text { STREAM LEAKAGE PERIOD } & 1 & \text { STEP } & 50\end{array}$

LAYER ROW COL STREAM RCH. FLOW INTO FLOW TO FLOW OUT OF OVRLND. DIRECT STREAM STREAM STREAM STREAM STREAMBED STREAMBED SEG.NO. NO. STRM. RCH. AQUIFER STRM. RCH. RUNOFF PRECIP ET HEAD DEPTH WIDTH CONDCTNC. GRADIENT

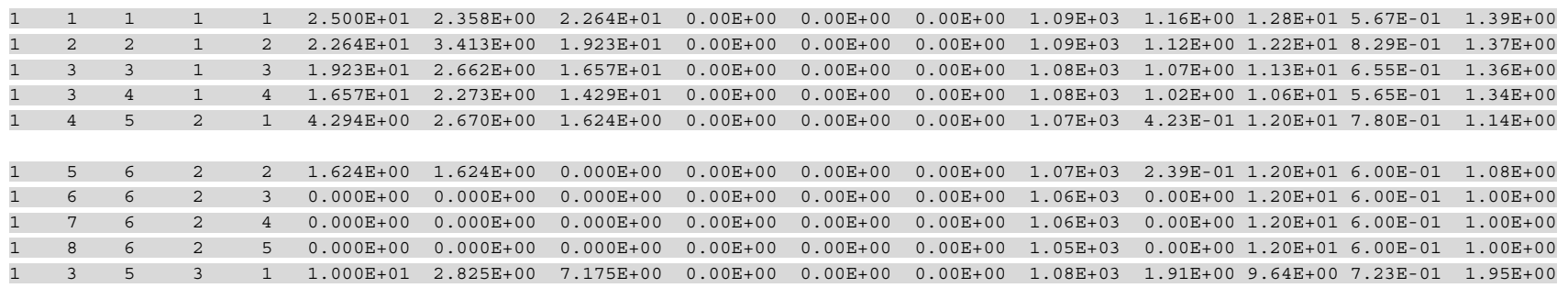

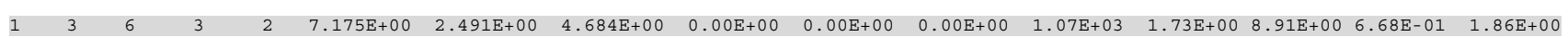

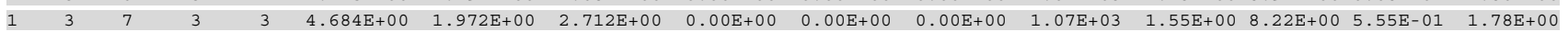

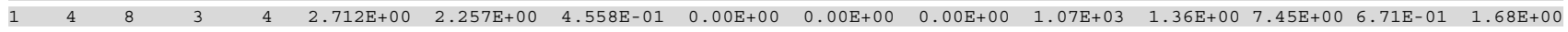
$\begin{array}{llllllllllllllll}1 & 5 & 8 & 3 & 5 & 4.558 \mathrm{E}-01 & 4.558 \mathrm{E}-01 & 0.000 \mathrm{E}+00 & 0.00 \mathrm{E}+00 & 0.00 \mathrm{E}+00 & 0.00 \mathrm{E}+00 & 1.06 \mathrm{E}+03 & 1.16 \mathrm{E}+00 & 6.65 \mathrm{E}+00 & 4.99 \mathrm{E}-01 & 1.58 \mathrm{E}+00\end{array}$ $\begin{array}{lllllllllllllllllll}1 & 6 & 8 & 3 & 6 & 0.000 \mathrm{E}+00 & 0.000 \mathrm{E}+00 & 0.000 \mathrm{E}+00 & 0.00 \mathrm{E}+00 & 0.00 \mathrm{E}+00 & 0.00 \mathrm{E}+00 & 1.06 \mathrm{E}+03 & 0.00 \mathrm{E}+00 & 6.15 \mathrm{E}+00 & 1.84 \mathrm{E}-01 & 1.00 \mathrm{E}+00\end{array}$

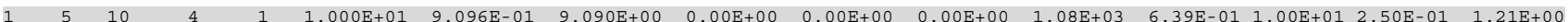

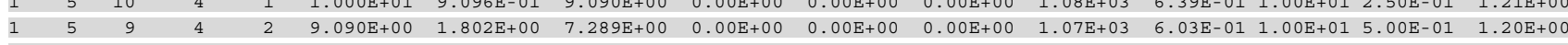

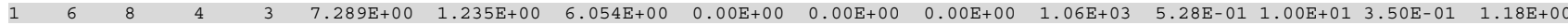
$\begin{array}{llllllllllllllll}1 & 6 & 8 & 5 & 1 & 6.054 \mathrm{E}+00 & 1.360 \mathrm{E}+00 & 4.694 \mathrm{E}+00 & 0.00 \mathrm{E}+00 & 0.00 \mathrm{E}+00 & 0.00 \mathrm{E}+00 & 1.06 \mathrm{E}+03 & 5.40 \mathrm{E}-01 & 1.04 \mathrm{E}+01 & 3.84 \mathrm{E}-01 & 1.18 \mathrm{E}+00\end{array}$

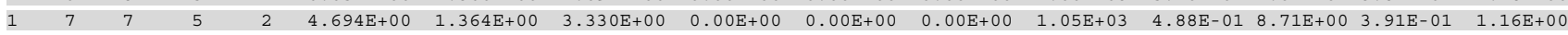

$\begin{array}{llllllllllllllll}1 & 8 & 7 & 5 & 3 & 3.330 \mathrm{E}+00 & 8.012 \mathrm{E}-01 & 2.529 \mathrm{E}+00 & 0.00 \mathrm{E}+00 & 0.00 \mathrm{E}+00 & 0.00 \mathrm{E}+00 & 1.05 \mathrm{E}+03 & 4.38 \mathrm{E}-01 & 7.25 \mathrm{E}+00 & 2.33 \mathrm{E}-01 & 1.15 \mathrm{E}+00\end{array}$

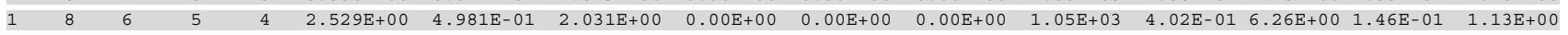

$\begin{array}{llllllllllllllll}1 & 9 & 6 & 6 & 1 & 2.031 \mathrm{E}+00 & 1.964 \mathrm{E}+00 & 6.701 \mathrm{E}-02 & 0.00 \mathrm{E}+00 & 0.00 \mathrm{E}+00 & 0.00 \mathrm{E}+00 & 1.04 \mathrm{E}+03 & 2.73 \mathrm{E}-01 & 1.20 \mathrm{E}+01 & 6.00 \mathrm{E}-01 & 1.09 \mathrm{E}+00\end{array}$

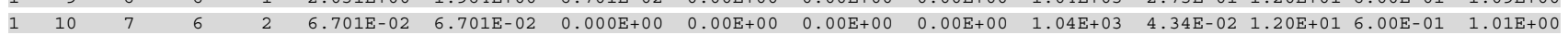
$\begin{array}{llllllllllllllll}1 & 11 & 7 & 6 & 3 & 0.000 \mathrm{E}+00 & 0.000 \mathrm{E}+00 & 0.000 \mathrm{E}+00 & 0.00 \mathrm{E}+00 & 0.00 \mathrm{E}+00 & 0.00 \mathrm{E}+00 & 1.03 \mathrm{E}+03 & 0.00 \mathrm{E}+00 & 1.20 \mathrm{E}+01 & 6.00 \mathrm{E}-01 & 1.00 \mathrm{E}+00\end{array}$

$\begin{array}{lllllllllllllllll}1 & 12 & 7 & 6 & 4 & 0.000 \mathrm{E}+00 & 0.000 \mathrm{E}+00 & 0.000 \mathrm{E}+00 & 0.00 \mathrm{E}+00 & 0.00 \mathrm{E}+00 & 0.00 \mathrm{E}+00 & 1.03 \mathrm{E}+03 & 0.00 \mathrm{E}+00 & 1.20 \mathrm{E}+01 & 6.00 \mathrm{E}-01 & 1.00 \mathrm{E}+00\end{array}$ $\begin{array}{lllllllllllllllll}1 & 13 & 7 & 6 & 5 & 0.000 \mathrm{E}+00 & -2.320 \mathrm{E}-01 & 2.320 \mathrm{E}-01 & 0.00 \mathrm{E}+00 & 0.00 \mathrm{E}+00 & 0.00 \mathrm{E}+00 & 1.03 \mathrm{E}+03 & 0.00 \mathrm{E}+00 & 1.20 \mathrm{E}+01 & 2.40 \mathrm{E}-01 & -3.22 \mathrm{E}-01\end{array}$ 


\section{A new Streamflow-Routing (SFR1) Package}

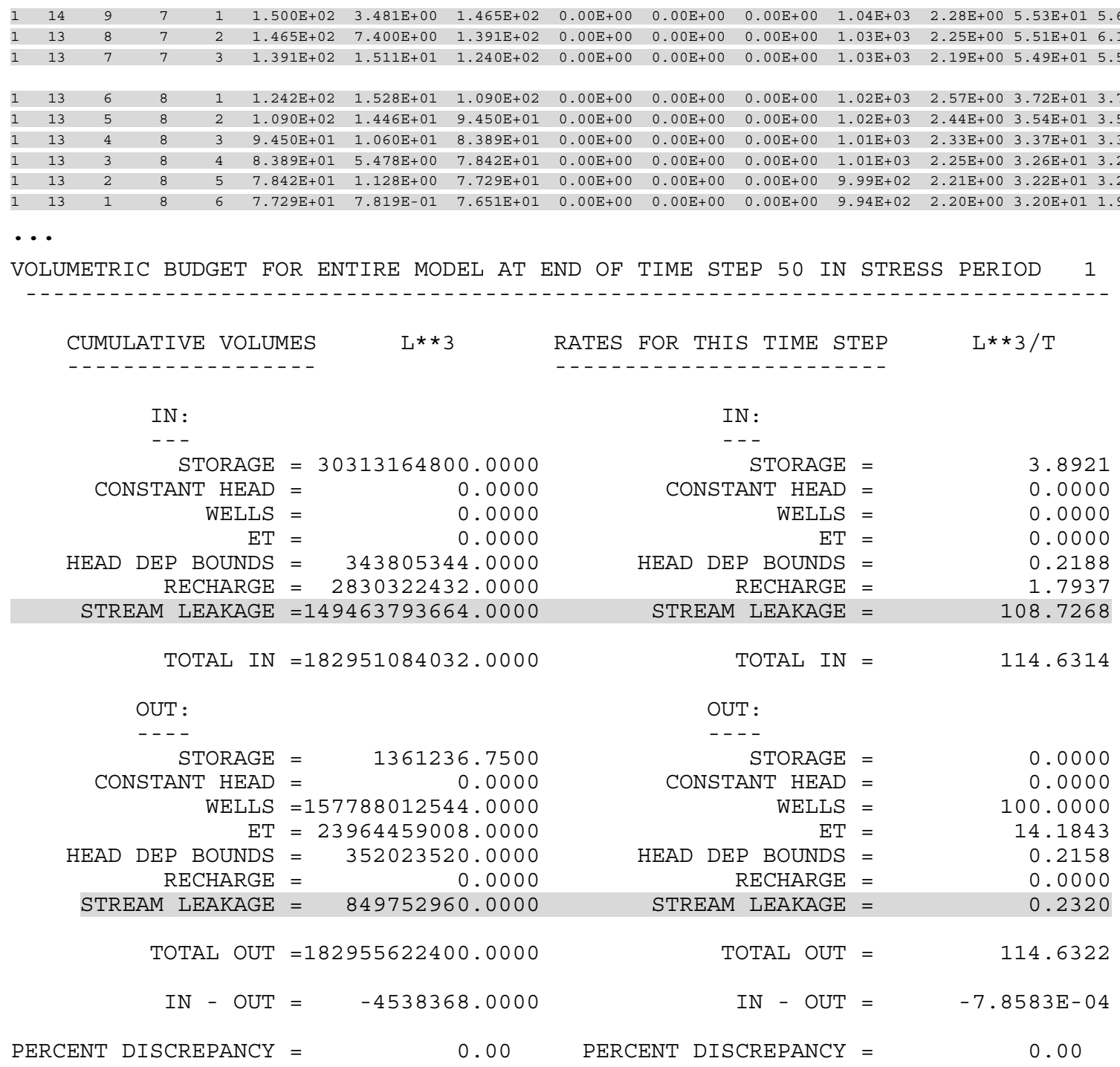

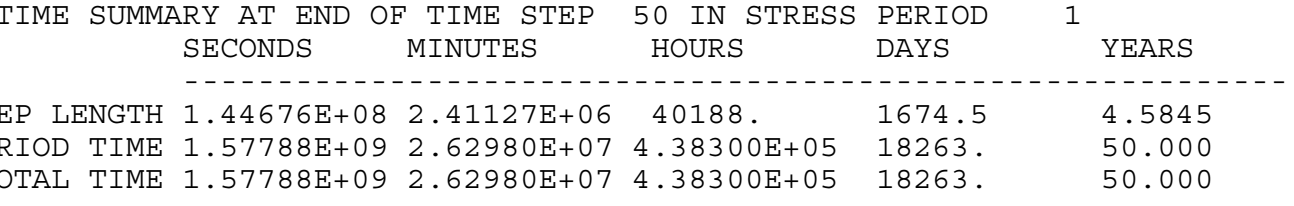

$\cdots$

SOLVING FOR HEAD

4 ITERATIONS FOR TIME STEP 50 IN STRESS PERIOD 2

MAXIMUM HEAD CHANGE FOR EACH ITERATION:

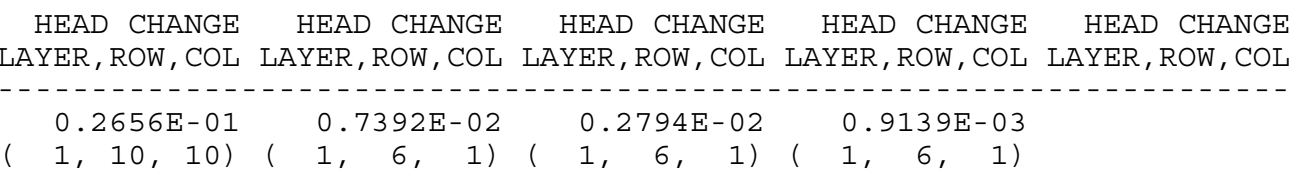


Appendix 2: Test simulation 175

STREAM LEAKAGE PERIOD 2 STEP 50

LAYER ROW COL STREAM RCH. FLOW INTO FLOW TO FLOW OUT OF OVRLND. DIRECT STREAM STREAM STREAM STREAM STREAMBED STREAMBE SEG.NO. NO. STRM. RCH. AQUIFER STRM. RCH. RUNOFF PRECIP ET HEAD DEPTH WIDTH CONDCTNC. GRADIEN $\begin{array}{llllllllllllllllllll}1 & 1 & 1 & 1 & 1 & 2.500 \mathrm{E}+01 & 8.032 \mathrm{E}-01 & 2.420 \mathrm{E}+01 & 0.00 \mathrm{E}+00 & 0.00 \mathrm{E}+00 & 0.00 \mathrm{E}+00 & 1.09 \mathrm{E}+03 & 1.17 \mathrm{E}+00 & 1.31 \mathrm{E}+01 & 5.94 \mathrm{E}-01 & 4.51 \mathrm{E}-01 \\ 1 & 2 & 2 & 1 & 2 & 2.420 \mathrm{E}+01 & 2.170 \mathrm{E}+00 & 2.203 \mathrm{E}+01 & 0.00 \mathrm{E}+00 & 0.00 \mathrm{E}+00 & 0.00 \mathrm{E}+00 & 1.09 \mathrm{E}+03 & 1.15 \mathrm{E}+00 & 1.27 \mathrm{E}+01 & 8.72 \mathrm{E}-01 & 8.30 \mathrm{E}-01 \\ 1 & 3 & 3 & 1 & 3 & 2.203 \mathrm{E}+01 & 2.911 \mathrm{E}+00 & 1.911 \mathrm{E}+01 & 0.00 \mathrm{E}+00 & 0.00 \mathrm{E}+00 & 0.00 \mathrm{E}+00 & 1.08 \mathrm{E}+03 & 1.11 \mathrm{E}+00 & 1.21 \mathrm{E}+01 & 7.08 \mathrm{E}-01 & 1.37 \mathrm{E}+00 \\ 1 & 3 & 4 & 1 & 4 & 1.911 \mathrm{E}+01 & 2.470 \mathrm{E}+00 & 1.665 \mathrm{E}+01 & 0.00 \mathrm{E}+00 & 0.00 \mathrm{E}+00 & 0.00 \mathrm{E}+00 & 1.08 \mathrm{E}+03 & 1.07 \mathrm{E}+00 & 1.13 \mathrm{E}+01 & 6.07 \mathrm{E}-01 & 1.36 \mathrm{E}+00\end{array}$ $\begin{array}{llllllllllllllll}1 & 3 & 4 & 1 & 4 & 1.911 \mathrm{E}+01 & 2.470 \mathrm{E}+00 & 1.665 \mathrm{E}+01 & 0.00 \mathrm{E}+00 & 0.00 \mathrm{E}+00 & 0.00 \mathrm{E}+00 & 1.08 \mathrm{E}+03 & 1.07 \mathrm{E}+00 & 1.13 \mathrm{E}+01 & 6.07 \mathrm{E}-01 & 1.36 \mathrm{E}+00 \\ 1 & 4 & 5 & 2 & 1 & 6.645 \mathrm{E}+00 & 2.767 \mathrm{E}+00 & 3.879 \mathrm{E}+00 & 0.00 \mathrm{E}+00 & 0.00 \mathrm{E}+00 & 0.00 \mathrm{E}+00 & 1.07 \mathrm{E}+03 & 5.47 \mathrm{E}-01 & 1.20 \mathrm{E}+01 & 7.80 \mathrm{E}-01 & 1.18 \mathrm{E}+00\end{array}$ $\begin{array}{lllllllllllllllllllllll}1 & 5 & 6 & 2 & 2 & 3.879 \mathrm{E}+00 & 2.038 \mathrm{E}+00 & 1.840 \mathrm{E}+00 & 0.00 \mathrm{E}+00 & 0.00 \mathrm{E}+00 & 0.00 \mathrm{E}+00 & 1.07 \mathrm{E}+03 & 3.97 \mathrm{E}-01 & 1.20 \mathrm{E}+01 & 6.00 \mathrm{E}-01 & 1.13 \mathrm{E}+00 \\ 1 & 6 & 6 & 2 & 3 & 1.840 \mathrm{E}+00 & 1.840 \mathrm{E}+00 & 0.000 \mathrm{E}+00 & 0.00 \mathrm{E}+00 & 0.00 \mathrm{E}+00 & 0.00 \mathrm{E}+00 & 1.06 \mathrm{E}+03 & 2.55 \mathrm{E}-01 & 1.20 \mathrm{E}+01 & 6.00 \mathrm{E}-01 & 1.09 \mathrm{E}+00 \\ 1 & 7 & 6 & 2 & 4 & 0.000 \mathrm{E}+00 & 0.000 \mathrm{E}+00 & 0.000 \mathrm{E}+00 & 0.00 \mathrm{E}+00 & 0.00 \mathrm{E}+00 & 0.00 \mathrm{E}+00 & 1.06 \mathrm{E}+03 & 0.00 \mathrm{E}+00 & 1.20 \mathrm{E}+01 & 6.00 \mathrm{E}-01 & 1.00 \mathrm{E}+00 \\ 1 & 8 & 6 & 2 & 5 & 0.000 \mathrm{E}+00 & 0.000 \mathrm{E}+00 & 0.000 \mathrm{E}+00 & 0.00 \mathrm{E}+00 & 0.00 \mathrm{E}+00 & 0.00 \mathrm{E}+00 & 1.05 \mathrm{E}+03 & 0.00 \mathrm{E}+00 & 1.20 \mathrm{E}+01 & 6.00 \mathrm{E}-01 & 1.00 \mathrm{E}+00\end{array}$ $\begin{array}{llllllllllllllllll}1 & 8 & 6 & 2 & 5 & 0.000 \mathrm{E}+00 & 0.000 \mathrm{E}+00 & 0.000 \mathrm{E}+00 & 0.00 \mathrm{E}+00 & 0.00 \mathrm{E}+00 & 0.00 \mathrm{E}+00 & 1.05 \mathrm{E}+03 & 0.00 \mathrm{E}+00 & 1.20 \mathrm{E}+01 & 6.00 \mathrm{E}-01 & 1.00 \mathrm{E}+00\end{array}$

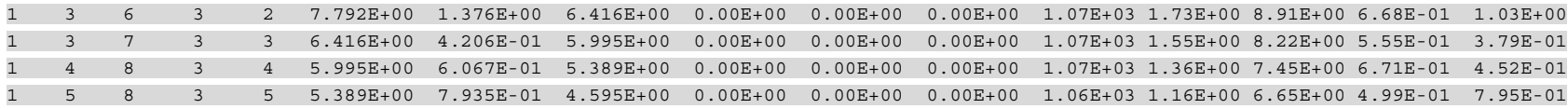

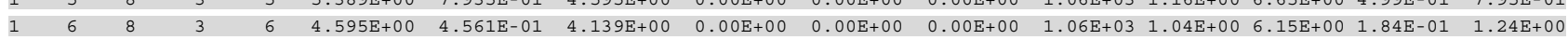

$\begin{array}{rrrrrrrrrrrrrrrr}1 & 5 & 10 & 4 & 1 & 1.000 \mathrm{E}+01 & 9.096 \mathrm{E}-01 & 9.090 \mathrm{E}+00 & 0.00 \mathrm{E}+00 & 0.00 \mathrm{E}+00 & 0.00 \mathrm{E}+00 & 1.08 \mathrm{E}+03 & 6.39 \mathrm{E}-01 & 1.00 \mathrm{E}+01 & 2.50 \mathrm{E}-01 & 1.21 \mathrm{E}+00 \\ 1 & 5 & 9 & 4 & 2 & 9.090 \mathrm{E}+00 & 1.802 \mathrm{E}+00 & 7.289 \mathrm{E}+00 & 0.00 \mathrm{E}+00 & 0.00 \mathrm{E}+00 & 0.00 \mathrm{E}+00 & 1.07 \mathrm{E}+03 & 6.03 \mathrm{E}-01 & 1.00 \mathrm{E}+01 & 5.00 \mathrm{E}-01 & 1.20 \mathrm{E}+00 \\ 1 & 6 & 8 & 4 & 3 & 7.289 \mathrm{E}+00 & 1.235 \mathrm{E}+00 & 6.054 \mathrm{E}+00 & 0.00 \mathrm{E}+00 & 0.00 \mathrm{E}+00 & 0.00 \mathrm{E}+00 & 1.06 \mathrm{E}+03 & 5.28 \mathrm{E}-01 & 1.00 \mathrm{E}+01 & 3.50 \mathrm{E}-01 & 1.18 \mathrm{E}+00 \\ 1 & 6 & 8 & 5 & 1 & 1.019 \mathrm{E}+01 & -2.691 \mathrm{E}-01 & 1.046 \mathrm{E}+01 & 0.00 \mathrm{E}+00 & 0.00 \mathrm{E}+00 & 0.00 \mathrm{E}+00 & 1.06 \mathrm{E}+03 & 6.79 \mathrm{E}-01 & 1.53 \mathrm{E}+01 & 6.28 \mathrm{E}-01 & -1.43 \mathrm{E}-01 \\ 1 & 7 & 7 & 5 & 2 & 1.046 \mathrm{E}+01 & 7.635 \mathrm{E}-01 & 9.699 \mathrm{E}+00 & 0.00 \mathrm{E}+00 & 0.00 \mathrm{E}+00 & 0.00 \mathrm{E}+00 & 1.05 \mathrm{E}+03 & 6.74 \mathrm{E}-01 & 1.55 \mathrm{E}+01 & 7.96 \mathrm{E}-01 & 3.20 \mathrm{E}-01\end{array}$

\begin{tabular}{|c|c|c|c|c|c|c|c|c|c|c|c|c|c|c|c|}
\hline & 8 & 7 & 5 & 3 & $9.699 \mathrm{E}+00$ & $1.010 \mathrm{E}+00$ & $8.689 \mathrm{E}+00$ & $0.00 \mathrm{E}+00$ & $0.00 \mathrm{E}+00$ & $0.00 \mathrm{E}+00$ & $1.05 \mathrm{E}+03$ & $6.52 \mathrm{E}-01$ & $1.44 \mathrm{E}+01$ & $4.86 \mathrm{E}-01$ & $6.93 E-01$ \\
\hline & 8 & 6 & 5 & 4 & $8.689 \mathrm{E}+00$ & $1.536 \mathrm{E}-01$ & $8.535 E+00$ & $0.00 \mathrm{E}+00$ & $0.00 \mathrm{E}+00$ & $0.00 \mathrm{E}+00$ & $1.05 \mathrm{E}+03$ & $6.37 \mathrm{E}-01$ & $1.39 \mathrm{E}+01$ & $3.57 \mathrm{E}-01$ & $1.44 \mathrm{E}-01$ \\
\hline & 9 & 6 & & 1 & $.535 \mathrm{E}+00$ & $1.373 \mathrm{E}+00$ & $7.162 \mathrm{E}+00$ & $0.00 \mathrm{E}+00$ & $0.00 \mathrm{E}+00$ & $0.00 \mathrm{E}+00$ & $1.04 \mathrm{E}+03$ & $6.09 \mathrm{E}-01$ & $1.20 \mathrm{E}+01$ & $6.00 \mathrm{E}-01$ & $7.63 \mathrm{E}-01$ \\
\hline & 10 & 7 & & 2 & $7.162 \mathrm{E}+00$ & $1.330 \mathrm{E}+00$ & $5.832 \mathrm{E}+00$ & $0.00 \mathrm{E}+00$ & $0.00 \mathrm{E}+00$ & $0.00 \mathrm{E}+00$ & $1.04 \mathrm{E}+03$ & $5.45 \mathrm{E}-01$ & $1.20 \mathrm{E}+01$ & $6.00 \mathrm{E}-01$ & $7.39 \mathrm{E}-01$ \\
\hline & 11 & 7 & ( & 3 & $5.832 \mathrm{E}+00$ & $1.216 \mathrm{E}+00$ & $4.615 \mathrm{E}+00$ & $.00 \mathrm{E}+00$ & $0.00 \mathrm{E}+00$ & $0.00 \mathrm{E}+00$ & $1.03 E+03$ & $4.79 \mathrm{E}-01$ & 1. $20 \mathrm{E}+01$ & $6.00 \mathrm{E}-01$ & $.76 \mathrm{E}-$ \\
\hline & 12 & 7 & 6 & 4 & $4.615 E+00$ & $5.695 \mathrm{E}-01$ & $.046 \mathrm{E}+00$ & $0.00 \mathrm{E}+00$ & $0.00 \mathrm{E}+00$ & $0.00 \mathrm{E}+00$ & $1.03 E+03$ & -01 & +01 & 6.00 & $.16 \mathrm{E}-$ \\
\hline & 13 & 7 & 6 & 5 & $4.046 \mathrm{E}+00$ & $-6.607 \mathrm{E}-01$ & $4.707 \mathrm{E}+00$ & $0.00 \mathrm{E}+00$ & $0.00 \mathrm{E}+00$ & $0.00 \mathrm{E}+00$ & $1.03 \mathrm{E}+03$ & $4.32 \mathrm{E}-01$ & $1.20 \mathrm{E}+01$ & $2.40 \mathrm{E}-01$ & $-9.18 \mathrm{E}-01$ \\
\hline & 14 & 9 & 7 & 1 & $1.500 \mathrm{E}+02$ & $2.957 \mathrm{E}+00$ & $1.470 \mathrm{E}+02$ & $0.00 \mathrm{E}+00$ & $0.00 \mathrm{E}+00$ & $0.00 \mathrm{E}+00$ & $1.04 \mathrm{E}+03$ & $2.28 \mathrm{E}+00$ & $5.53 \mathrm{E}+01$ & $5.60 \mathrm{E}+00$ & 1. $76 \mathrm{E}-01$ \\
\hline & 13 & 8 & 7 & 2 & $1.470 \mathrm{E}+02$ & $4.053 \mathrm{E}+00$ & $1.430 \mathrm{E}+02$ & $0.00 \mathrm{E}+00$ & $0.00 \mathrm{E}+00$ & $0.00 \mathrm{E}+00$ & $1.03 E+03$ & $2.26 \mathrm{E}+00$ & $5.52 \mathrm{E}+01$ & $6.13 E+00$ & $2.20 \mathrm{E}-01$ \\
\hline & 13 & 7 & 7 & 3 & $1.430 \mathrm{E}+02$ & $3.182 \mathrm{E}+00$ & $1.398 \mathrm{E}+02$ & $0.00 \mathrm{E}+00$ & $0.00 \mathrm{E}+00$ & $0.00 \mathrm{E}+00$ & $1.03 E+03$ & $2.24 E+00$ & $5.51 \mathrm{E}+01$ & $5.58 \mathrm{E}+00$ & 1. $90 \mathrm{E}-01$ \\
\hline & 13 & 6 & $\varepsilon$ & 1 & $1.445 \mathrm{E}+02$ & $1.571 \mathrm{E}+00$ & $1.429 \mathrm{E}+02$ & $0.00 \mathrm{E}+00$ & $0.00 \mathrm{E}+00$ & $0.00 \mathrm{E}+00$ & $1.02 \mathrm{E}+03$ & $2.77 \mathrm{E}+00$ & $4.03 E+01$ & $4.12 \mathrm{E}+00$ & $1.27 \mathrm{E}-01$ \\
\hline & 13 & 5 & 8 & 2 & $1.429 \mathrm{E}+02$ & $-1.255 \mathrm{E}+00$ & $1.442 \mathrm{E}+02$ & $0.00 \mathrm{E}+00$ & $0.00 \mathrm{E}+00$ & $0.00 \mathrm{E}+00$ & $1.02 \mathrm{E}+03$ & $2.77 \mathrm{E}+00$ & $4.01 \mathrm{E}+01$ & $4.10 \mathrm{E}+00$ & $-1.02 \mathrm{E}-01$ \\
\hline & 13 & 4 & 8 & 3 & $1.442 \mathrm{E}+02$ & $-2.969 \mathrm{E}+00$ & $1.472 \mathrm{E}+02$ & $0.00 \mathrm{E}+00$ & $0.00 \mathrm{E}+00$ & $0.00 \mathrm{E}+00$ & $1.01 \mathrm{E}+03$ & $2.78 \mathrm{E}+00$ & $4.04 \mathrm{E}+01$ & $4.13 \mathrm{E}+00$ & $-2.40 E-01$ \\
\hline & 13 & 3 & 8 & 4 & $1.472 \mathrm{E}+02$ & $-3.053 \mathrm{E}+00$ & $1.502 \mathrm{E}+02$ & $0.00 \mathrm{E}+00$ & $0.00 \mathrm{E}+00$ & $0.00 \mathrm{E}+00$ & $1.01 \mathrm{E}+03$ & $2.81 \mathrm{E}+00$ & $4.07 \mathrm{E}+01$ & $4.16 \mathrm{E}+00$ & $-2.44 \mathrm{E}-01$ \\
\hline & 13 & 2 & 8 & 5 & $1.502 \mathrm{E}+02$ & $-1.112 \mathrm{E}+00$ & $1.513 E+02$ & $0.00 \mathrm{E}+00$ & $0.00 \mathrm{E}+00$ & $0.00 \mathrm{E}+00$ & $1.00 \mathrm{E}+03$ & $2.82 \mathrm{E}+00$ & $4.08 \mathrm{E}+01$ & $4.18 \mathrm{E}+00$ & $-8.88 E-02$ \\
\hline & 13 & 1 & 8 & 6 & 1. $513 \mathrm{E}+02$ & $4.133 \mathrm{E}-01$ & $1.509 \mathrm{E}+02$ & $0.00 \mathrm{E}+00$ & $0.00 \mathrm{E}+00$ & $0.00 \mathrm{E}+00$ & $9.95 \mathrm{E}+02$ & $2.82 \mathrm{E}+00$ & $4.09 \mathrm{E}+01$ & $2.51 \mathrm{E}+00$ & $5.48 \mathrm{E}-02$ \\
\hline
\end{tabular}

\section{- •}

VOLUMETRIC BUDGET FOR ENTIRE MODEL AT END OF TIME STEP 50 IN STRESS PERIOD 2

\begin{tabular}{|c|c|c|c|}
\hline CUMULATIVE VOLUM & $L * * 3$ & RATES FOR THIS TIME STEP & $\mathrm{L} * * 3 / \mathrm{T}$ \\
\hline IN : & & IN : & \\
\hline STORAGE & $=30333497344.0000$ & STORAGE = & $4.2187 E-06$ \\
\hline CONSTANT HEAD & 0.0000 & CONSTANT HEAD $=$ & 0.0000 \\
\hline WELLS & 0.0000 & WELLS = & 0.0000 \\
\hline ET & 0.0000 & $\mathrm{ET}=$ & 0.0000 \\
\hline HEAD DEP BOUNDS & 684446208.0000 & HEAD DEP BOUNDS = & 0.2152 \\
\hline RECHARGE & 5660645888.0000 & RECHARGE = & 1.7937 \\
\hline STREAM LEAKAGE & $=231710588928.0000$ & STREAM LEAKAGE = & 43.3992 \\
\hline
\end{tabular}

OUT :

OUT : 


\section{A new Streamflow-Routing (SFR1) Package}

\begin{tabular}{|c|c|c|c|c|}
\hline STORAGE & $=30327783424.0000$ & STORAGE & $=$ & $8.6505 E-03$ \\
\hline CONSTANT HEAD & $=\quad 0.0000$ & CONSTANT HEAD & $=$ & 0.0000 \\
\hline WELLS & $=157788012544.0000$ & WELLS & $=$ & 0.000 \\
\hline $\mathrm{ET}$ & $=68290981888.0000$ & $\mathrm{ET}$ & $=$ & 35.8371 \\
\hline HEAD DEP BOUNDS & 736502400.0000 & HEAD DEP BOUNDS & $=$ & 0.248 \\
\hline RECHARGE & 0.0000 & RECHARGE & $=$ & 0.0000 \\
\hline STREAM LEAKAGE & $=11258482688.0000$ & STREAM LEAKAGE & $=$ & 9.3187 \\
\hline TOTAL OUT & $=268401770496.0000$ & TOTAL OUT & $=$ & 45.4127 \\
\hline IN - OUT & -12582912.0000 & IN - OUT & $=$ & $-4.5547 \mathrm{E}-03$ \\
\hline CENT DISCREPANCY & 0.00 & PERCENT DISCREPANCY & $=$ & -0.01 \\
\hline
\end{tabular}

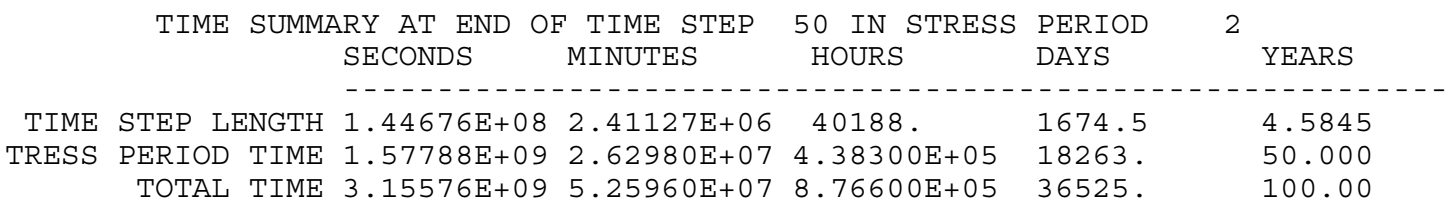

Following (enclosed in a border) are the abridged contents of Gaging Station 5 output file for the transient part of test simulation 1:

File name: test1tr.sg5

\begin{tabular}{|c|c|c|c|c|c|c|c|c|}
\hline "GAGE No. & $K, I, J$ & Coord. = & 1, & STREAM & SEGMENT & 5 ; & $\mathrm{BACH}=$ & $"$ \\
\hline "DATA: Time & Stage & Flow & Depth & Width & M-P Flow & Cond. & HeadDiff & Hyd.Grad \\
\hline $1.356 \mathrm{E}+06$ & $1.047 \mathrm{E}+03$ & $8.346 \mathrm{E}+00$ & $6.337 \mathrm{E}-01$ & $1.382 \mathrm{E}+01$ & $8.602 \mathrm{E}+00$ & $3.548 \mathrm{E}-01$ & $7.583 \mathrm{E}-01$ & $2.528 \mathrm{E}-01$ \\
\hline \multicolumn{9}{|l|}{$\cdots$} \\
\hline $4.487 \mathrm{E}+06$ & $1.047 \mathrm{E}+03$ & $7.490 \mathrm{E}+00$ & $6.181 \mathrm{E}-01$ & $1.346 \mathrm{E}+01$ & $8.227 \mathrm{E}+00$ & $3.456 \mathrm{E}-01$ & $2.099 \mathrm{E}+00$ & $6.997 \mathrm{E}-01$ \\
\hline \multicolumn{9}{|l|}{$\cdots$} \\
\hline $1.046 \mathrm{E}+07$ & $1.047 \mathrm{E}+03$ & $5.678 \mathrm{E}+00$ & $5.674 \mathrm{E}-01$ & $1.132 \mathrm{E}+01$ & $6.658 \mathrm{E}+00$ & $2.697 \mathrm{E}-01$ & $3.567 \mathrm{E}+00$ & $1.189 \mathrm{E}+00$ \\
\hline \multicolumn{9}{|l|}{$\cdots$} \\
\hline $2.512 \mathrm{E}+07$ & $1.047 \mathrm{E}+03$ & $3.565 \mathrm{E}+00$ & $4.852 \mathrm{E}-01$ & $8.652 \mathrm{E}+00$ & $4.307 E+00$ & $2.046 \mathrm{E}-01$ & $3.485 E+00$ & $1.162 \mathrm{E}+00$ \\
\hline \multicolumn{9}{|l|}{$\cdots$} \\
\hline $5.497 \mathrm{E}+07$ & $1.047 \mathrm{E}+03$ & $2.031 \mathrm{E}+00$ & $4.019 E-01$ & $6.261 \mathrm{E}+00$ & $2.556 \mathrm{E}+00$ & $1.464 \mathrm{E}-01$ & $3.402 \mathrm{E}+00$ & $1.134 \mathrm{E}+00$ \\
\hline \multicolumn{9}{|l|}{$\cdots$} \\
\hline $2.239 \mathrm{E}+09$ & $1.047 \mathrm{E}+03$ & $2.031 \mathrm{E}+00$ & $4.019 \mathrm{E}-01$ & $6.261 \mathrm{E}+00$ & $2.556 \mathrm{E}+00$ & $1.464 \mathrm{E}-01$ & $3.402 \mathrm{E}+00$ & $1.134 \mathrm{E}+00$ \\
\hline $2.307 \mathrm{E}+09$ & $1.047 \mathrm{E}+03$ & $4.056 \mathrm{E}+00$ & $4.997 \mathrm{E}-01$ & $9.363 \mathrm{E}+00$ & $4.495 \mathrm{E}+00$ & $2.420 \mathrm{E}-01$ & $1.774 \mathrm{E}+00$ & $5.912 \mathrm{E}-01$ \\
\hline $2.381 \mathrm{E}+09$ & $1.047 \mathrm{E}+03$ & $6.639 \mathrm{E}+00$ & $5.868 \mathrm{E}-01$ & $1.215 \mathrm{E}+01$ & $6.936 \mathrm{E}+00$ & $3.125 \mathrm{E}-01$ & $9.211 \mathrm{E}-01$ & $3.070 \mathrm{E}-01$ \\
\hline $2.463 \mathrm{E}+09$ & $1.047 \mathrm{E}+03$ & $7.810 \mathrm{E}+00$ & $6.191 \mathrm{E}-01$ & $1.326 \mathrm{E}+01$ & $8.029 \mathrm{E}+00$ & $3.407 \mathrm{E}-01$ & $6.208 \mathrm{E}-01$ & $2.069 \mathrm{E}-01$ \\
\hline \multicolumn{9}{|l|}{$\cdots$} \\
\hline $2.760 \mathrm{E}+09$ & $1.047 \mathrm{E}+03$ & $8.491 \mathrm{E}+00$ & $6.360 \mathrm{E}-01$ & $1.385 \mathrm{E}+01$ & $8.635 \mathrm{E}+00$ & $3.556 \mathrm{E}-01$ & $4.422 \mathrm{E}-01$ & $1.474 \mathrm{E}-01$ \\
\hline \multicolumn{9}{|l|}{$\cdots$} \\
\hline $3.156 \mathrm{E}+09$ & $1.047 \mathrm{E}+03$ & $8.535 E+00$ & $6.371 \mathrm{E}-01$ & $1.389 \mathrm{E}+01$ & $8.676 \mathrm{E}+00$ & $3.566 \mathrm{E}-01$ & $4.306 \mathrm{E}-01$ & $1.435 \mathrm{E}-01$ \\
\hline
\end{tabular}




\section{APPENDIX 3: SELECTED INPUT DATA AND PRINTED RESULTS FOR TEST SIMULATION 2}

This simulation is designed to demonstrate the capability of the Streamflow-Routing (SFR1) Package when used in conjunction with the Lake (LAK3) Package and the Ground-Water Transport (GWT) Process of MODFLOW (MODFLOW-GWT). This test case assumes steadystate flow and transient transport. Variables used in test simulation 2 are presented in table 3 . The extent of the model grid for layer 1, boundary conditions, and locations of lakes and streams are illustrated in figure 13. Selected results are shown in figures 14-17.

Selected sections of several key input and output data files are shown below-sometimes with annotations; gaps in the listings are indicated by an ellipsis. A complete set of these files is available for distribution over the Internet as discussed in the Preface. Contents of some files are enclosed in a border and explanations are noted outside of the border; for other files, explanations are sometimes included as comments following a semi-colon on the line being explained. Some brief annotations were added to the selected output listings to help the reader understand the purpose of various sections of output. These annotations are written in bold italics. Font sizes in the following listings are sometimes reduced so that lines will fit within page margins. Information pertaining specifically to the SFR1 Package is highlighted by shading. 


\section{Listing of Selected Input Data Sets for Test Simulation 2}

Following (enclosed in a border) are the contents of the MODFLOW name file for test simulation 2; explanations are noted outside of border:

File name: teststrm.nam

\begin{tabular}{|c|c|c|}
\hline LIST & 10 teststrm.1st & $\leftarrow$ Output file for MODFLOW-2000 \\
\hline DIS & 87 teststrm.dis & $\leftarrow$ Input file for Discretization Package \\
\hline BAS 6 & 11 teststrm.ba6 & $\leftarrow$ Input file for Basic Package \\
\hline OC & 12 teststrm.OC & $\leftarrow$ Input file for Output Control option \\
\hline BCF6 & 13 teststrm.bc6 & $\leftarrow$ Input file for Block-Centered Flow Package \\
\hline $\mathrm{RCH}$ & 14 teststrm.rch & $\leftarrow$ Input file for Recharge Package \\
\hline GWT & 70 teststrm.man & $\leftarrow$ Name file for Ground-Water Transport Process \\
\hline LAK & 19 teststrm.moc.lak & $\leftarrow$ Input file for Lake (LAK3) Package \\
\hline SFR & 18 teststrm.moc.sfr & $\leftarrow$ Input file for Streamflow-Routing (SFR1) Package \\
\hline GAGE & 22 teststrm.gge & $\leftarrow$ Input file for Gage Package \\
\hline SIP & 34 teststrm.sip & $\leftarrow$ Input file for Strongly Implicit Procedure Package \\
\hline DATA & 23 teststrm. fhd & $\leftarrow$ Output file for calculated heads \\
\hline DATA & 26 teststrm.gs 1 & $\leftarrow$ Output file for Lake 1 gaging station records \\
\hline DATA & 27 teststrm.gs 2 & $\leftarrow$ Output file for Lake 2 gaging station records \\
\hline DATA & 28 teststrm.sg1 & $\leftarrow$ Output file for Stream 1 gaging station records \\
\hline DATA & 29 teststrm.sg2 & $\leftarrow$ Output file for Stream 2 gaging station records \\
\hline DATA & 30 teststrm.sg3 & $\leftarrow$ Output file for Stream 3 gaging station records \\
\hline DATA & 31 teststrm.sg4 & $\leftarrow$ Output file for Stream 4 gaging station records \\
\hline DATA (BINARY) & 33 teststrm.bud & $\leftarrow$ Output file for cell-by-cell budget data \\
\hline$\uparrow$ & $\uparrow$ & \\
\hline 1 & 2 & \\
\hline
\end{tabular}

1 Ftype (that is, the type of file)

2 Unit number

3 File name (name chosen to reflect contents of file) 
Following (enclosed in a border) are the contents of the Basic Package input file for test simulation 2; explanations are noted outside of border:

File name: teststrm.ba 6

\begin{tabular}{|c|c|c|c|c|c|c|c|c|c|}
\hline \multicolumn{9}{|c|}{$\begin{array}{l}\text { \#Test of combined stream, lake, and solute-transport packages. } \\
\text { \#...loosely based on simplified model of Cape cod sewage plume. } \\
\text { FREE CHTOCH }\end{array}$} & $\begin{array}{l}\leftarrow 1 \\
\leftarrow 1 \\
\leftarrow 2\end{array}$ \\
\hline OPEN/CLOSE teststrm.i2 & 1 ' (FREE) & & 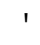 & 5 & IBOUND & layer & 1 & & $\leftarrow 3$ \\
\hline OPEN/CLOSE teststrm.iO & 1 ' (FREE) & & 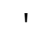 & 5 & IBOUND & layer & 2 & & -3 \\
\hline OPEN/CLOSE teststrm.i3 & 1 ' (FREE) & & ' & 5 & IBOUND & layer & 3 & & 5 \\
\hline OPEN/CLOSE teststrm.il & 1 ' (FREE) & & 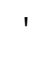 & 5 & IBOUND & layer & 4 & & -3 \\
\hline OPEN/CLOSE teststrm.il & 1 ' (FREE) & & 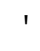 & 5 & IBOUND & layer & 5 & & -3 \\
\hline OPEN/CLOSE teststrm.il & 1 ' (FREE) & & ' & 5 & IBOUND & layer & 6 & & $\leftarrow 3$ \\
\hline OPEN/CLOSE teststrm.il & 1 ' (FREE) & & ' & 5 & UND & 1 & 7 & & -3 \\
\hline $\begin{array}{l}\text { OPEN/CLOSE teststrm.il } \\
999999.00 \text { HNOFLO }\end{array}$ & 1 ' (FREE) & & ' & 5 & IBOUND & layer & 8 & & $\begin{array}{l}\leftarrow 3 \\
\leftarrow 4\end{array}$ \\
\hline OPEN/CLOSE test & $1.000000 \mathrm{E}+00$ & ' (FREE) & ' & 2 & ial & d & layer & 1 & $\leftarrow 5$ \\
\hline OPEN/CLOSE teststrm.ho & $1.000000 \mathrm{E}+00$ & ' (FREE) & ' & 2 & Initial & ead & ayer & 2 & 5 \\
\hline OPEN/CLOSE teststrm.h2 & $1.000000 \mathrm{E}+00$ & ' (FREE) & ' & 2 & Initial & Head & layer & 3 & -5 \\
\hline OPEN/CLOSE teststrm.h2 & $1.000000 \mathrm{E}+00$ & ' (FREE) & ' & 2 & Initial & Head & layer & 4 & $\leftarrow 5$ \\
\hline OPEN/CLOSE teststrm.h2 & $1.000000 \mathrm{E}+00$ & ' (FREE) & ' & 2 & Initial & Head & layer & 5 & $\leftarrow 5$ \\
\hline OPEN/CLOSE teststrm.h2 & $1.000000 \mathrm{E}+00$ & ' (FREE) & ' & 2 & Initial & Head & layer & 6 & $\leftarrow$ \\
\hline OPEN/CLOSE teststrm.h2 & $1.000000 \mathrm{E}+00$ & ' (FREE) & ' & 2 & Initial & Head & layer & 7 & $\leftarrow 5$ \\
\hline OPEN/CLOSE teststrm.h2 & $1.000000 \mathrm{E}+00$ & ' (FREE) & 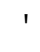 & 2 & Initial & Head & layer & 8 & $\leftarrow 5$ \\
\hline
\end{tabular}

1 Two header lines of comments.

2 Options line; "CHTOCH” recommended for GWT Process.

3 IBOUND arrays for each layer read from separate files.

4 Head value assigned to inactive cells.

5 Initial head information. 


\section{A new Streamflow-Routing (SFR1) Package}

Following (enclosed in a border) are the contents of the Discretization Package input file for test simulation 2; explanations are noted outside of border:

File name: teststrm.dis

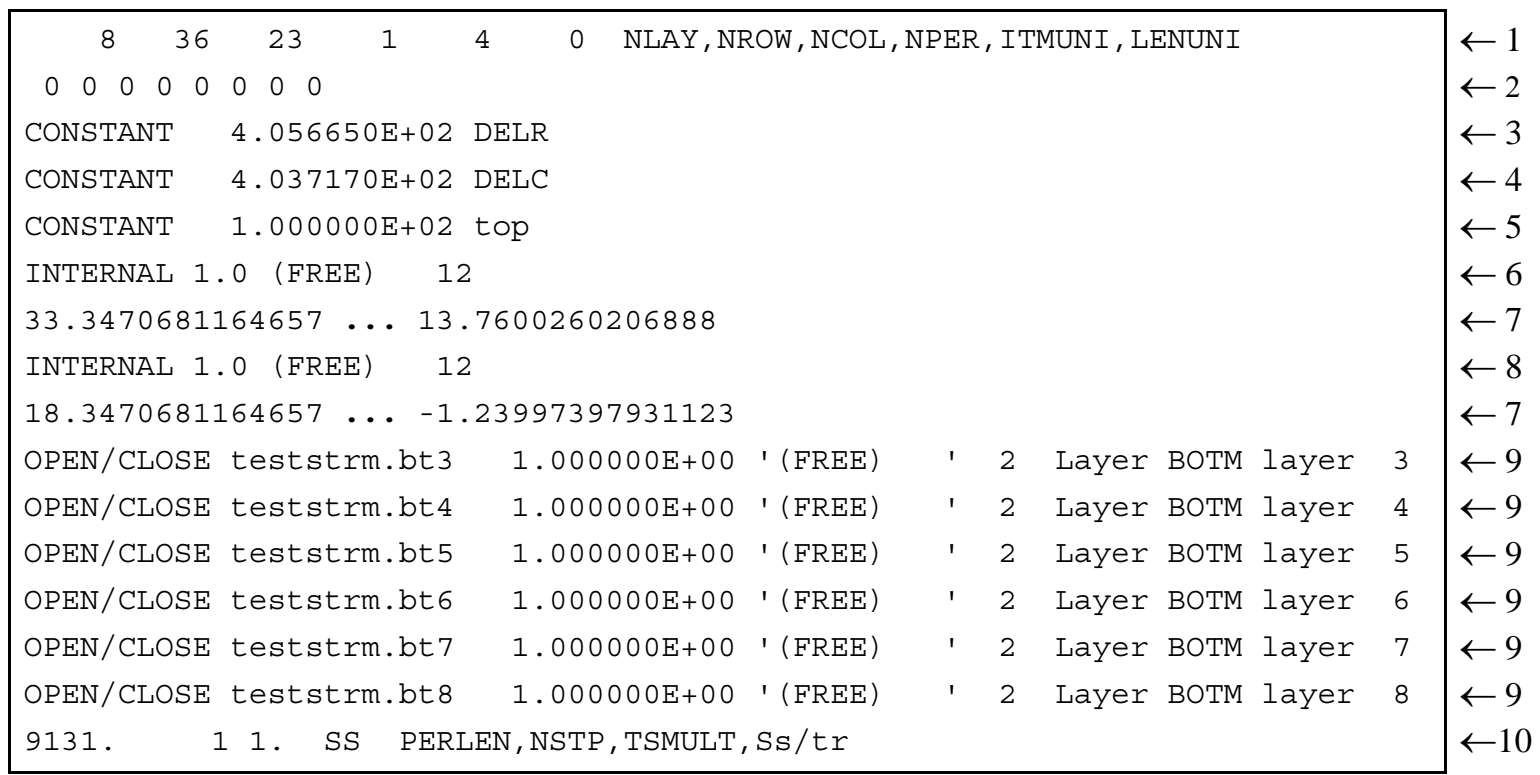

1 Grid characterization data.

2 Flags for quasi-3D simulation.

3 Row discretization data.

4 Column discretization data.

5 Top elevation for layer 1 .

6 Bottom elevations for layer 1 read from following data.

736 rows of data.

8 Bottom elevations for layer 2 read from following data.

9 Bottom elevations for indicated layers are read from separate files.

10 Time step and stress period information. 
Following (enclosed in a border) are the contents of the Block-Centered Flow Package input file for test simulation 2; explanations are noted outside of border:

File name: teststrm.bc6

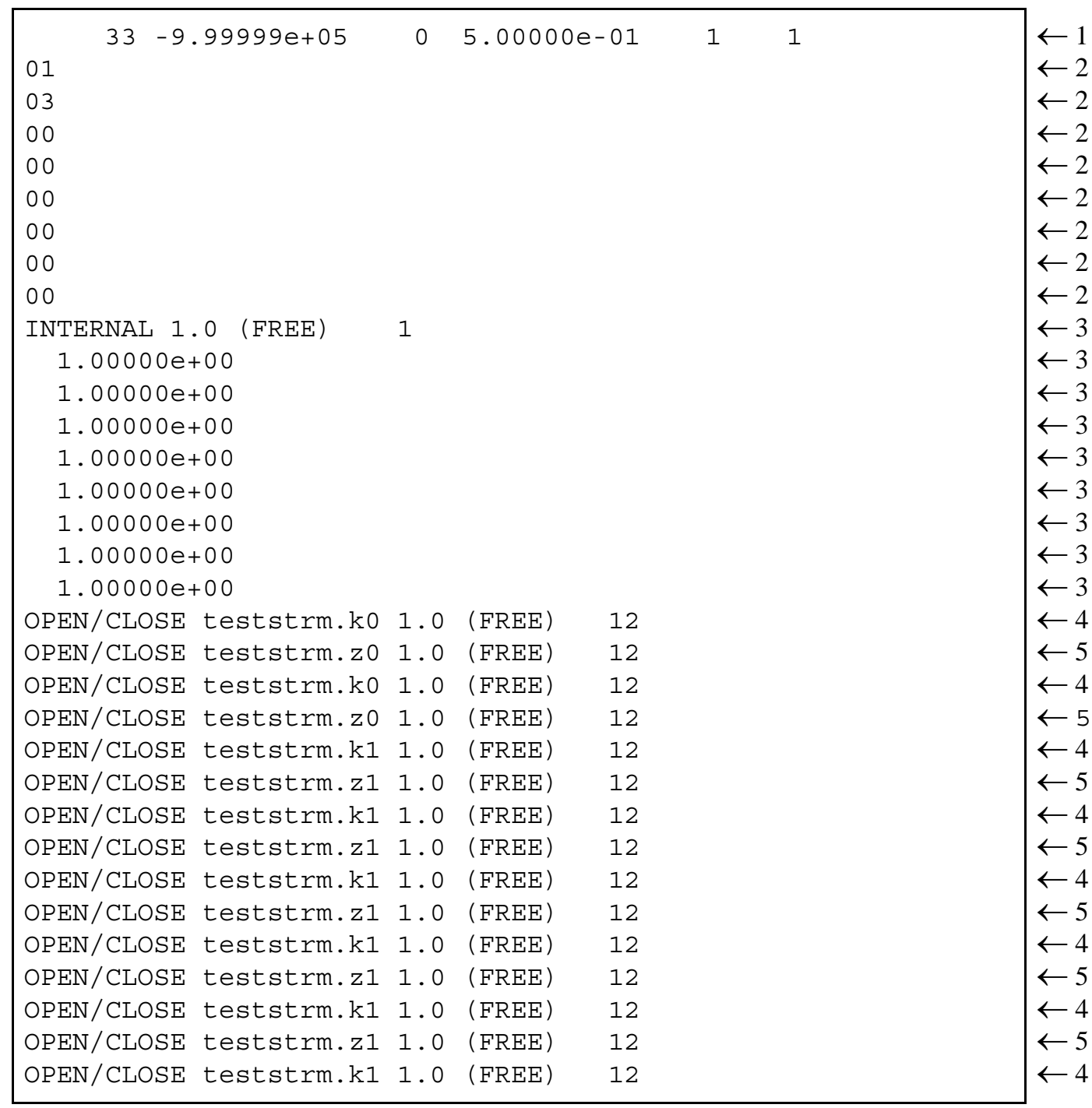

1 Flag for cell-by-cell flow terms, five flags or values related to wetting.

2 Layer type.

3 Anisotropy factor.

${ }^{4}$ Hydraulic conductivity data read from separate file.

5 Vertical conductance data read from separate file. 
Following are the contents of the Lake Package (LAK3) input file for test simulation 2; explanations are noted as comments at the end of each record:

File name: teststrm.moc.lak

\begin{tabular}{|c|c|c|c|c|}
\hline $2-1$ & & & & ! NLAKES, ILKCB \\
\hline$\odot . \odot$ & 0.00001 & & & ! THETA, NSSITR, SSCNCR \\
\hline 44.0 & 48.0 & $\odot . \odot$ & & ! Lake 1: STAGES, SSMN, SSMX, CLAKE \\
\hline 35.2 & 31.2 & $\odot . \odot$ & & ! Lake 2: STAGES, SSMN, SSMX, CLAKE \\
\hline 110 & & & & ! ITMP, ITMP1, LWRT \\
\hline OPEN/CLOSE & teststrm.lk1 & 1 (FREE) & 5 & ! Lake position array, Layer 1 \\
\hline OPEN/CLOSE & teststrm.lk0 & 1 (FREE) & 5 & ! Lake position array, Layer 2 \\
\hline OPEN/CLOSE & teststrm.lk0 & 1 (FREE) & 5 & ! Lake position array, Layer 3 \\
\hline OPEN/CLOSE & teststrm.lk0 & 1 (FREE) & 5 & ! Lake position array, Layer 4 \\
\hline OPEN/CLOSE & teststrm.lk0 & 1 (FREE) & 5 & ! Lake position array, Layer 5 \\
\hline OPEN/CLOSE & teststrm.lk0 & 1 (FREE) & 5 & ! Lake position array, Layer 6 \\
\hline OPEN/CLOSE & teststrm.lk0 & 1 (FREE) & 5 & ! Lake position array, Layer 7 \\
\hline OPEN/CLOSE & teststrm.lk0 & 1 (FREE) & 5 & ! Lake position array, Layer 8 \\
\hline CONSTANT & 1.0 & & & ! Lakebed leakance array, Layer 1 \\
\hline CONSTANT & 1.0 & & & ! Lakebed leakance array, Layer 2 \\
\hline CONSTANT & 1.0 & & & ! Lakebed leakance array, Layer 3 \\
\hline CONSTANT & 1.0 & & & ! Lakebed leakance array, Layer 4 \\
\hline CONSTANT & $1 . \odot$ & & & ! Lakebed leakance array, Layer 5 \\
\hline CONSTANT & 1.0 & & & ! Lakebed leakance array, Layer 6 \\
\hline CONSTANT & 1.0 & & & ! Lakebed leakance array, Layer 7 \\
\hline CONSTANT & $1 . \odot$ & & & ! Lakebed leakance array, Layer 8 \\
\hline$\odot$ & & & & ! NSLMS \\
\hline$\odot .0$ & $\odot . \odot \quad 0 . \odot$ & & & ! Lake 1: PRCPLK, EVAPLK, RNF, WTHDRW \\
\hline$\odot . \odot$ & $\odot . \odot$ & & & ! Lake 1: CPPT, CRNF, CAUG \\
\hline$\odot . \odot$ & $\odot . \odot \quad \odot . \odot$ & & & ! Lake 2: PRCPLK, EVAPLK, RNF, WTHDRW \\
\hline
\end{tabular}

Following (enclosed in a border) are the contents of the Streamflow-Routing Package (SFR1) input file for test simulation 2; explanations are noted outside of border:

File name: teststrm.moc.sfr

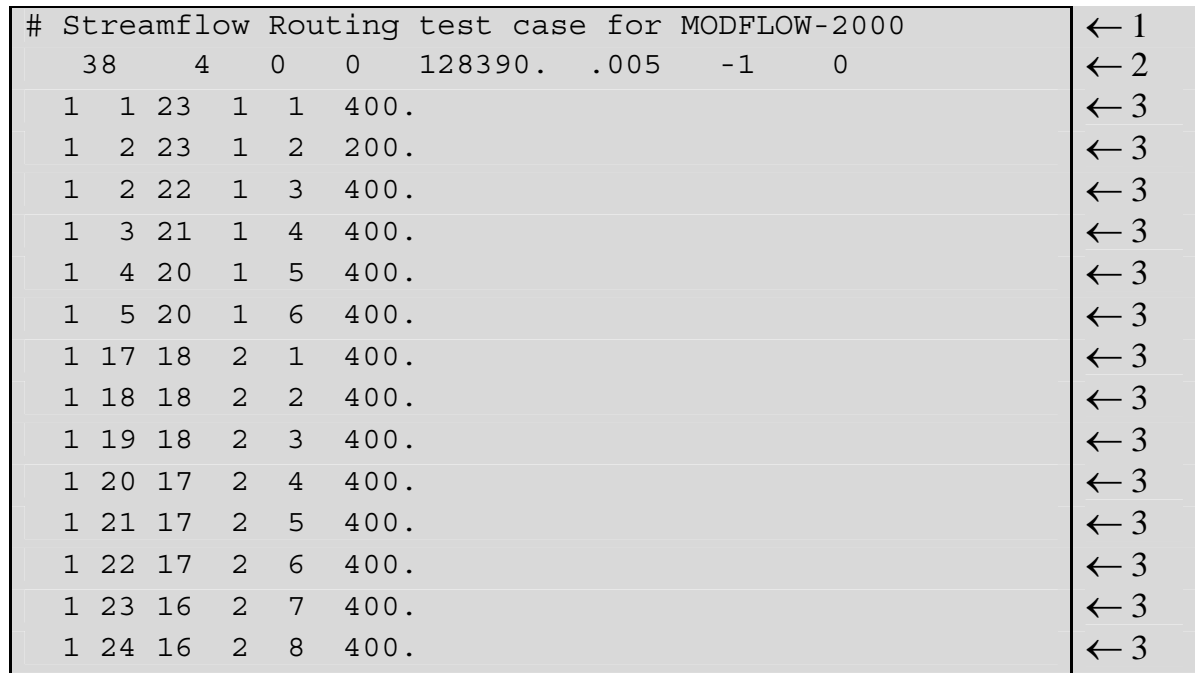




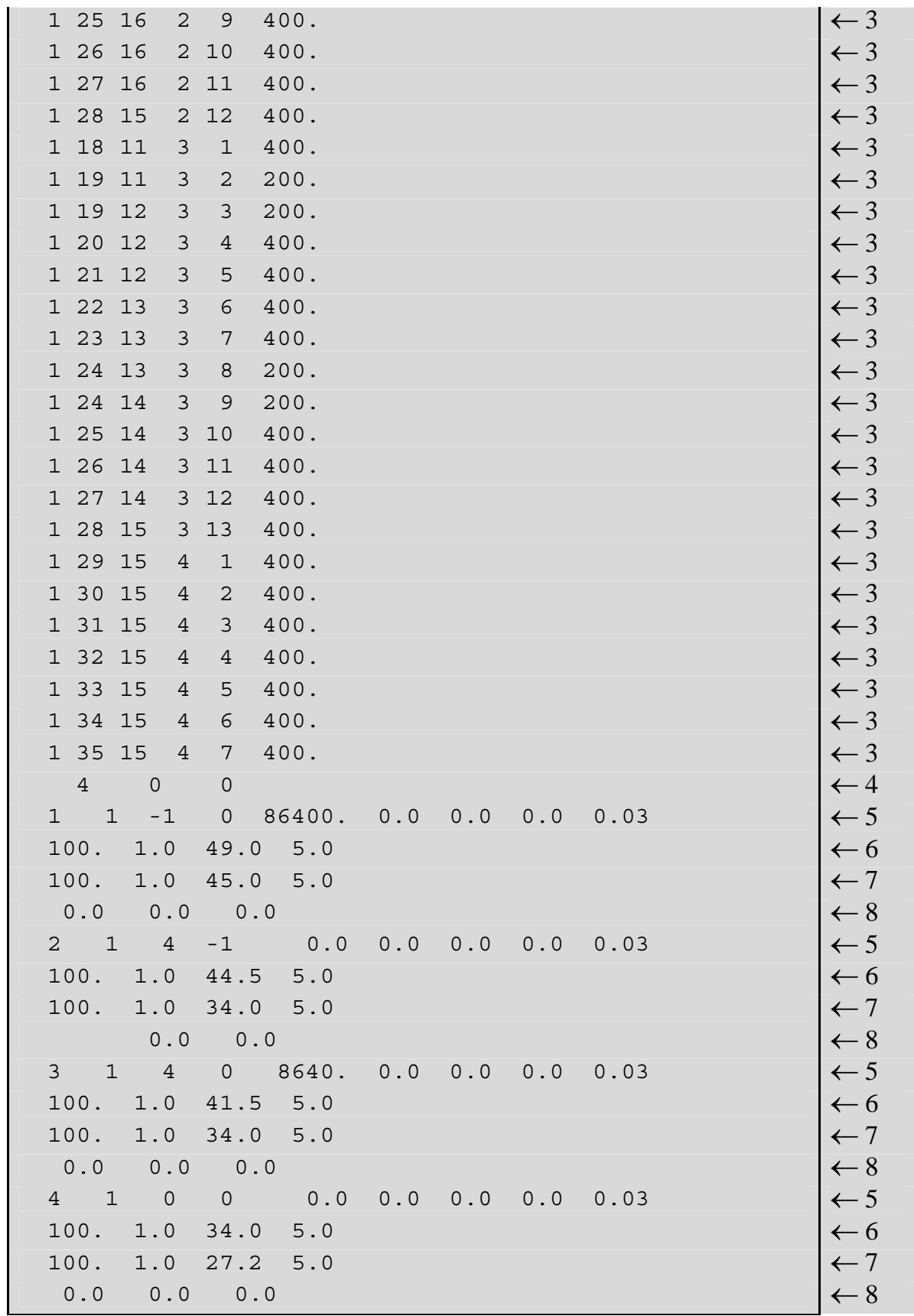

1 Optional text line for comments.

2 Input Item 1 (basic stream network description).

3 Input Item 2 (stream reach descriptions).

${ }^{4}$ Input Item 5 (flags for reading and printing data).

5 Input item 6a (general stream segment data).

6 Input item $6 \mathrm{~b}$ (stream segment data for upstream end).

7 Input item 6c (stream segment data for downstream end).

8 Input item 6f (source concentrations associated with inflows to stream segment). 
Following (enclosed in a border) are the contents of the Output-Control option input file for test simulation 2. Input was constructed in the optional style using words:

File name: teststrm. OC

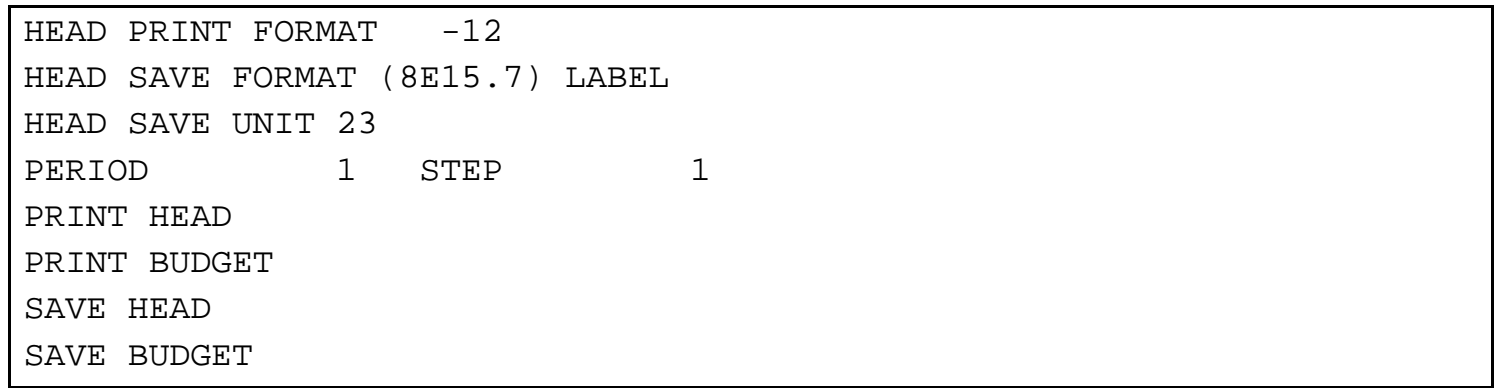

Following (enclosed in a border) are the contents of the Gage Package input file for test simulation 2; explanations are noted as comments at the end of each record (unit numbers are linked to a file name through the Ftype "DATA" in the MODFLOW name file):

File name: teststrm.gge

\begin{tabular}{|c|c|c|c|c|c|c|c|c|c|}
\hline 6 & & & & ; NUMGAGE (number of gaging & stations) & & & & \\
\hline 1 & 6 & 28 & 0 & ; STREAM SEGMENT \& REACH \#; & Output file & for & Gage & 1 & OUTTYPE \\
\hline 2 & 12 & 29 & 1 & ; STREAM SEGMENT \& REACH \#; & Output file & for & Gage & $2 ;$ & OUTTYPE \\
\hline 3 & 13 & 30 & 2 & ; STREAM SEGMENT \& REACH \#; & Output file & for & Gage & $3 ;$ & OUTTYPE \\
\hline 4 & 7 & 31 & 3 & ; STREAM SEGMENT \& REACH \#; & Output file & for & Gage & $4 ;$ & OUTTYPE \\
\hline-1 & 26 & & & ; Lake number; Unit no. for & output file & for & Gage & 5 & \\
\hline-2 & 27 & & & ; Lake number; Unit no. for & output file & for & Gage & 6 & \\
\hline
\end{tabular}

Following (enclosed in a border) are the contents of the Ground-Water Transport Process

File name: teststrm.mon

\begin{tabular}{|c|c|c|c|}
\hline CLST & & & $\leftarrow$ Output file for Ground-Water Transport Process \\
\hline $\mathrm{MOC}$ & 72 & teststrm.expl.moc & $\leftarrow$ Input file for GWT using explicit MOC transport solver \\
\hline OBS & 79 & teststrm.obs & $\leftarrow$ Input file for observation well package \\
\hline $\mathrm{CRCH}$ & 73 & teststrm.crc & $\leftarrow$ Input file for concentration of recharge \\
\hline CNCA & 74 & teststrm. cna & $\leftarrow$ Output file for calculated concentrations \\
\hline VELA & 76 & teststrm.vla & $\leftarrow$ Output file for calculated velocities \\
\hline DATA & 78 & teststrm.oba & $\leftarrow$ Output file for observation well records \\
\hline$\uparrow$ & $\uparrow$ & $\uparrow$ & \\
\hline 1 & 2 & 3 & \\
\hline \multicolumn{4}{|c|}{1 Ftype (that is, the type of file) } \\
\hline \multicolumn{4}{|c|}{2 Unit number } \\
\hline 3 File $\mathrm{r}$ & & (name chosen to reflect & its of file) \\
\hline
\end{tabular}


Following (enclosed in a border) are the contents of the Ground-Water Transport Process input file for test simulation 2; selected explanations are noted outside of border:

File name: teststrm.expl.moc

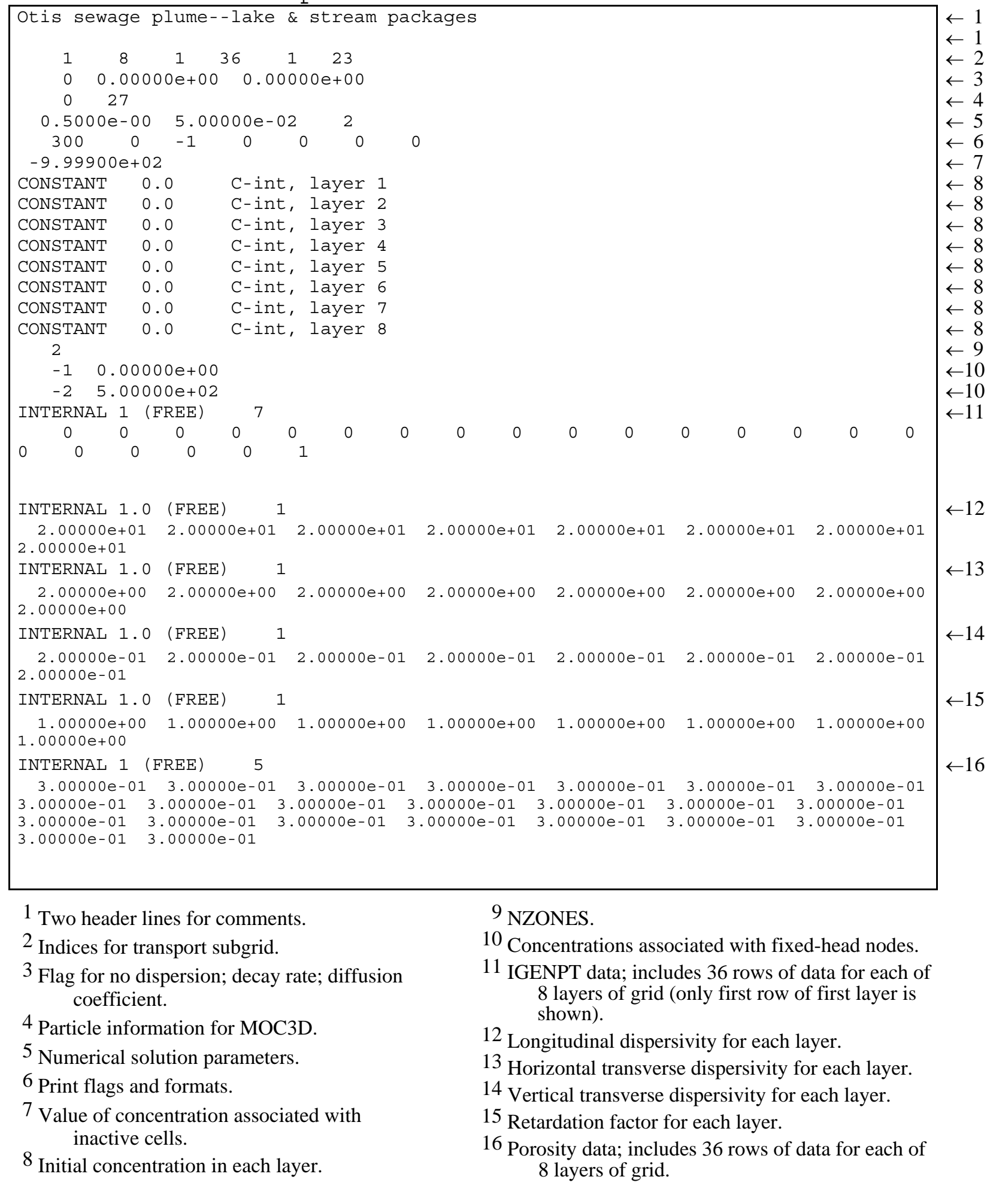




\section{Listing of Selected Output Files for Test Simulation 2}

Following are the contents of the main MODFLOW output file for test simulation 2:

File name: teststrm. lst

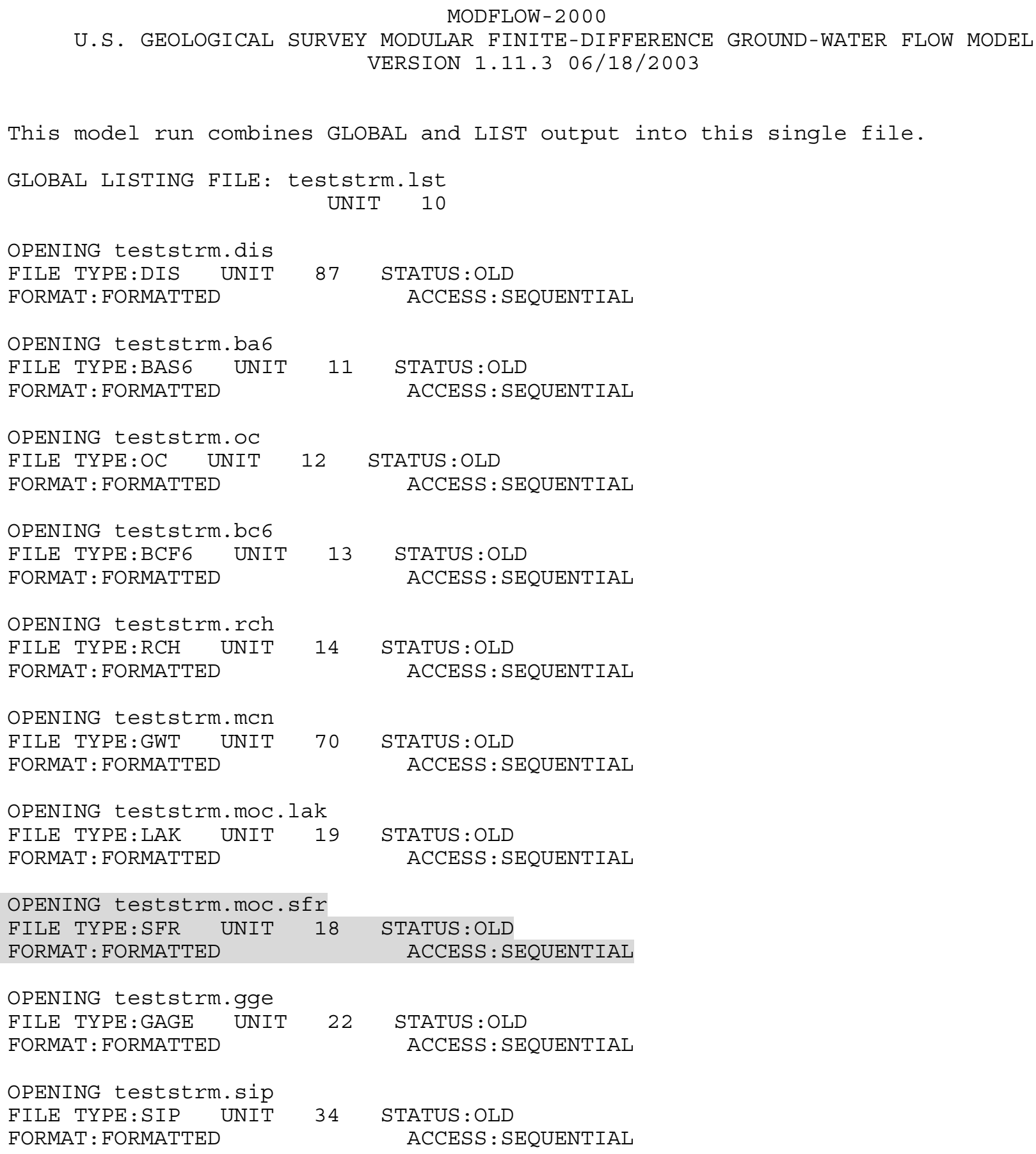




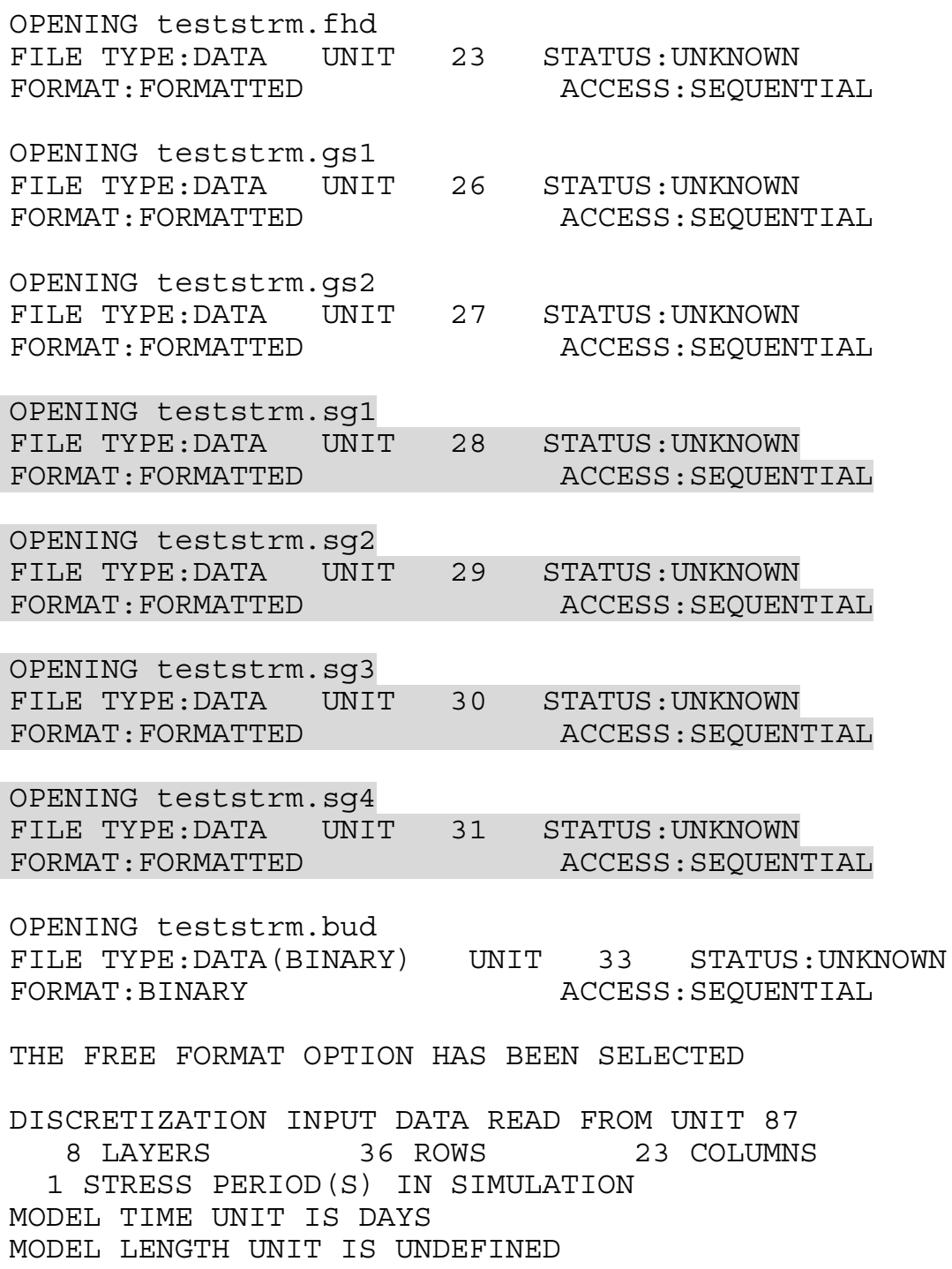




\section{A new Streamflow-Routing (SFR1) Package}

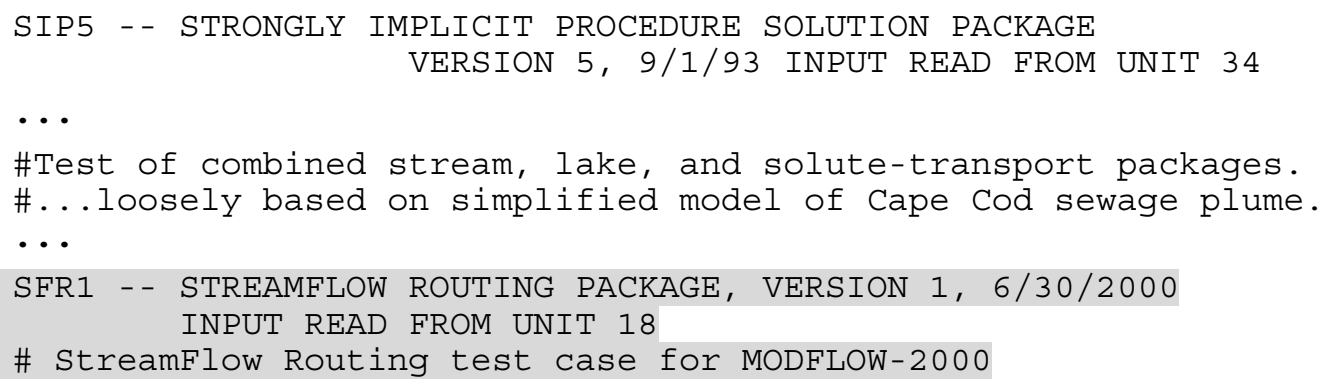

\begin{tabular}{|c|c|c|c|c|c|}
\hline LAYER & $\mathrm{ROW}$ & COL & $\begin{array}{l}\text { SEGMENT } \\
\text { NUMBER }\end{array}$ & $\begin{array}{l}\text { REACH } \\
\text { NUMBER }\end{array}$ & LENGTH \\
\hline \multicolumn{6}{|c|}{ - - - - - - - - - - - - - - - - - - - - - - - - - - - - - - - - - - - - - - - - - - - } \\
\hline 1 & 1 & 23 & 1 & 1 & $4.000 \mathrm{E}+02$ \\
\hline 1 & 2 & 23 & 1 & 2 & $2.000 E+02$ \\
\hline 1 & 2 & 22 & 1 & 3 & $4.000 \mathrm{E}+02$ \\
\hline 1 & 3 & 21 & 1 & 4 & $4.000 E+02$ \\
\hline 1 & 4 & 20 & 1 & 5 & $4.000 \mathrm{E}+02$ \\
\hline 1 & 5 & 20 & 1 & 6 & $4.000 E+02$ \\
\hline 1 & 17 & 18 & 2 & 1 & $4.000 \mathrm{E}+02$ \\
\hline 1 & 18 & 18 & 2 & 2 & $4.000 \mathrm{E}+02$ \\
\hline \multicolumn{6}{|l|}{$\cdots$} \\
\hline 1 & 27 & 14 & 3 & 12 & $4.000 \mathrm{E}+02$ \\
\hline 1 & 28 & 15 & 3 & 13 & $4.000 E+02$ \\
\hline 1 & 29 & 15 & 4 & 1 & $4.000 \mathrm{E}+02$ \\
\hline 1 & 30 & 15 & 4 & 2 & $4.000 E+02$ \\
\hline 1 & 31 & 15 & 4 & 3 & $4.000 \mathrm{E}+02$ \\
\hline 1 & 32 & 15 & 4 & 4 & $4.000 E+02$ \\
\hline 1 & 33 & 15 & 4 & 5 & $4.000 E+02$ \\
\hline 1 & 34 & 15 & 4 & 6 & $4.000 E+02$ \\
\hline 1 & 35 & 15 & 4 & 7 & $4.000 E+02$ \\
\hline
\end{tabular}

6 GAGING STATIONS WERE SPECIFIED.

(Lakes are identified by a negative value of the Lake Number) RECORDS WILL BE WRITTEN TO SEPARATE OUTPUT FILES REPRESENTED BY FOLLOWING UNIT NUMBERS: 


\begin{tabular}{|c|c|c|c|c|}
\hline \multicolumn{5}{|c|}{ Stream Gages: } \\
\hline \multirow[t]{2}{*}{ GAGE } & SEGMENT & REACH & UNIT & OUTTYPE \\
\hline & 1 & 6 & 28 & $\odot$ \\
\hline & 2 & 12 & 29 & 1 \\
\hline & 3 & 13 & 30 & 2 \\
\hline & 4 & 7 & 31 & 3 \\
\hline \multicolumn{5}{|c|}{ Lake Gages: } \\
\hline \multirow[t]{3}{*}{ GAGE } & LAKE & UNIT & OUTTYF & \\
\hline & -1 & 26 & & \\
\hline & -2 & 27 & & \\
\hline
\end{tabular}

CLASSIFICATION \& COUNT OF STREAM SEGMENTS BASED ON SOURCE OF INFLOW:

$\begin{array}{ccc}\text { HEADWATER } & \text { DIVERSION } & \text { RECEIVES TRIBUTARY FLOW } \\ -\cdots & -1 & 1\end{array}$

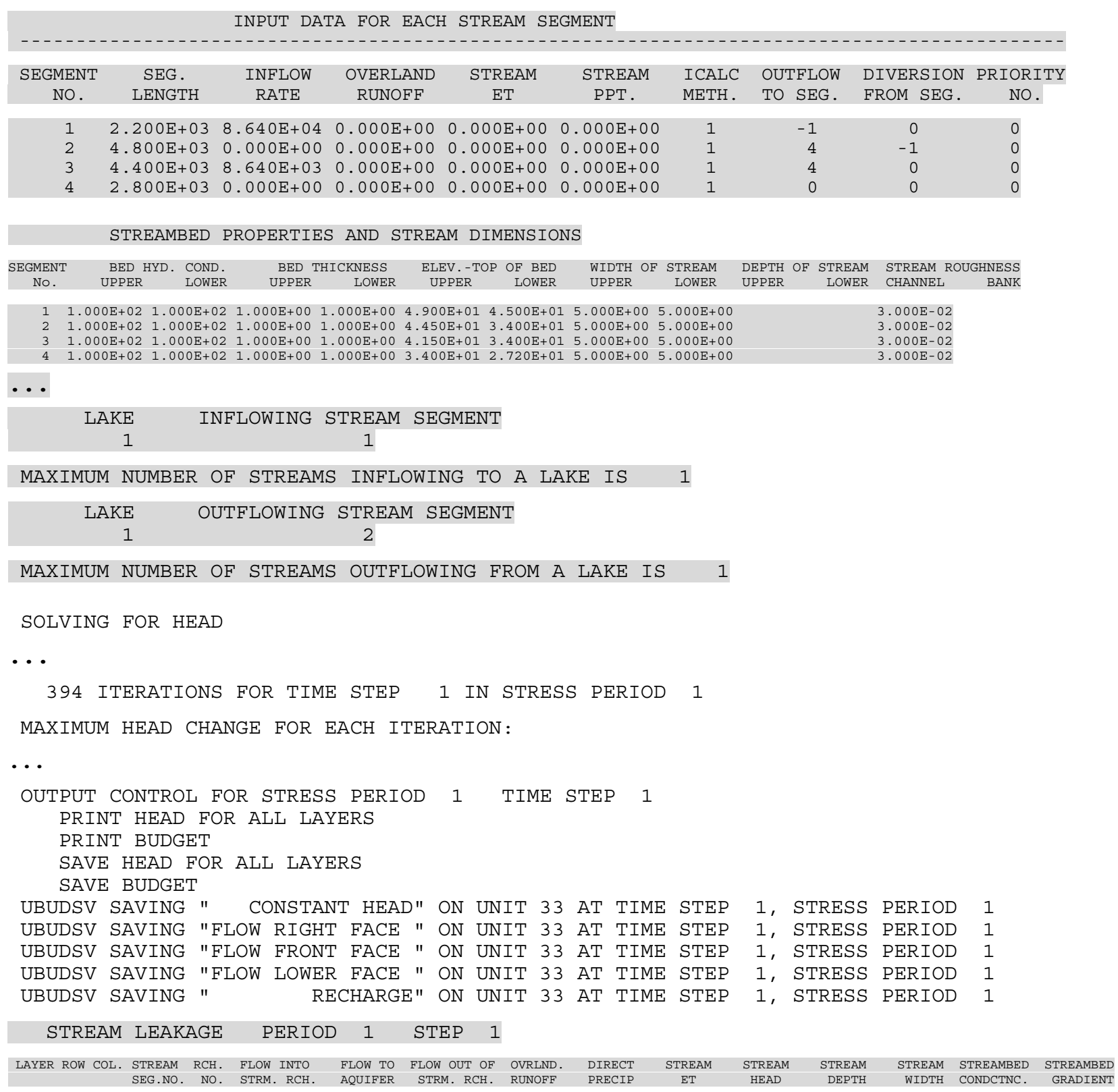




\section{A new Streamflow-Routing (SFR1) Package}

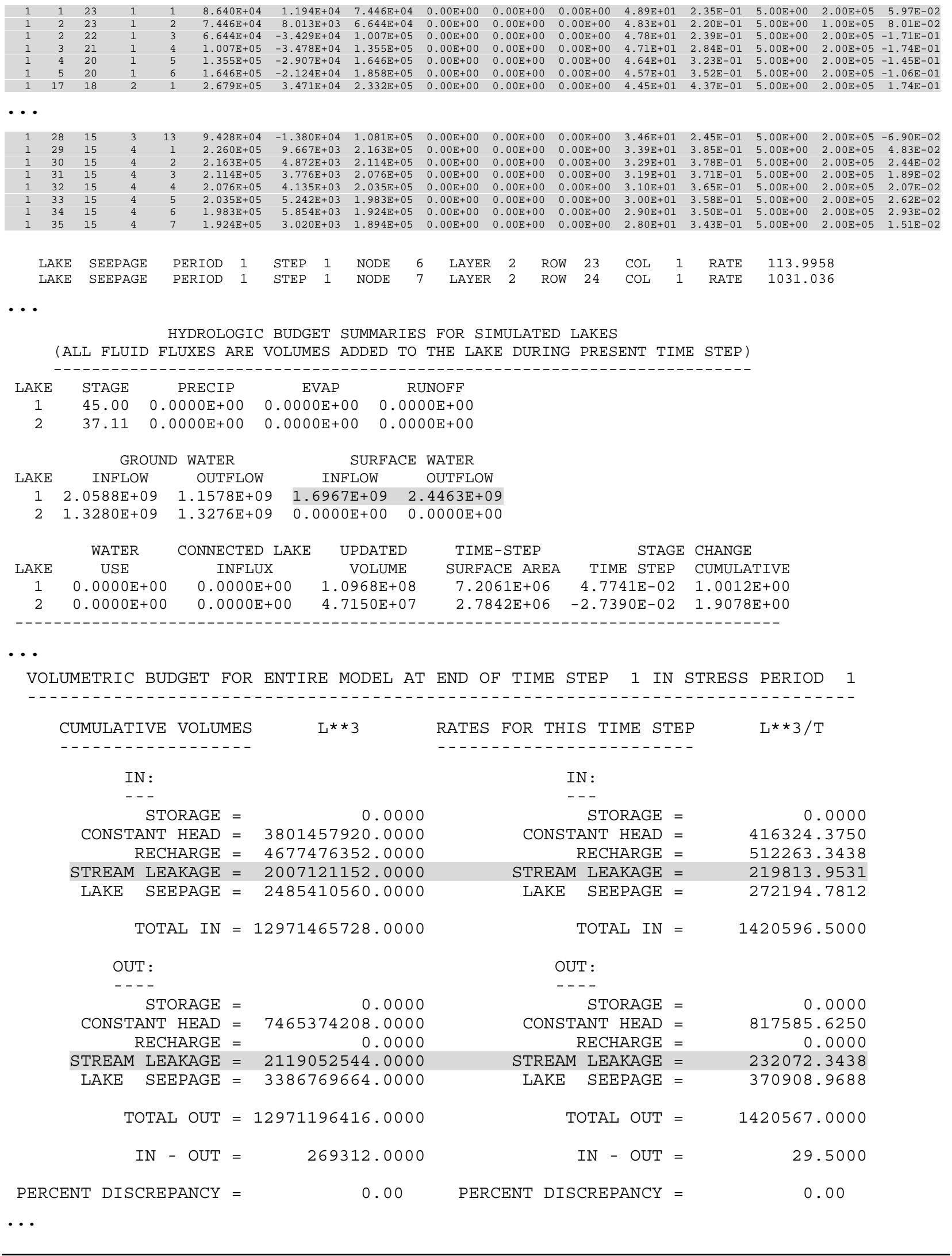


Following are the contents of the main Ground-Water Transport Process output file for test simulation 2:

File name: teststrm. out

U.S. GEOLOGICAL SURVEY

Ground-Water Transport Process (GWT)

GWT (Version 1.6 BETA SFR) Aug. 2003

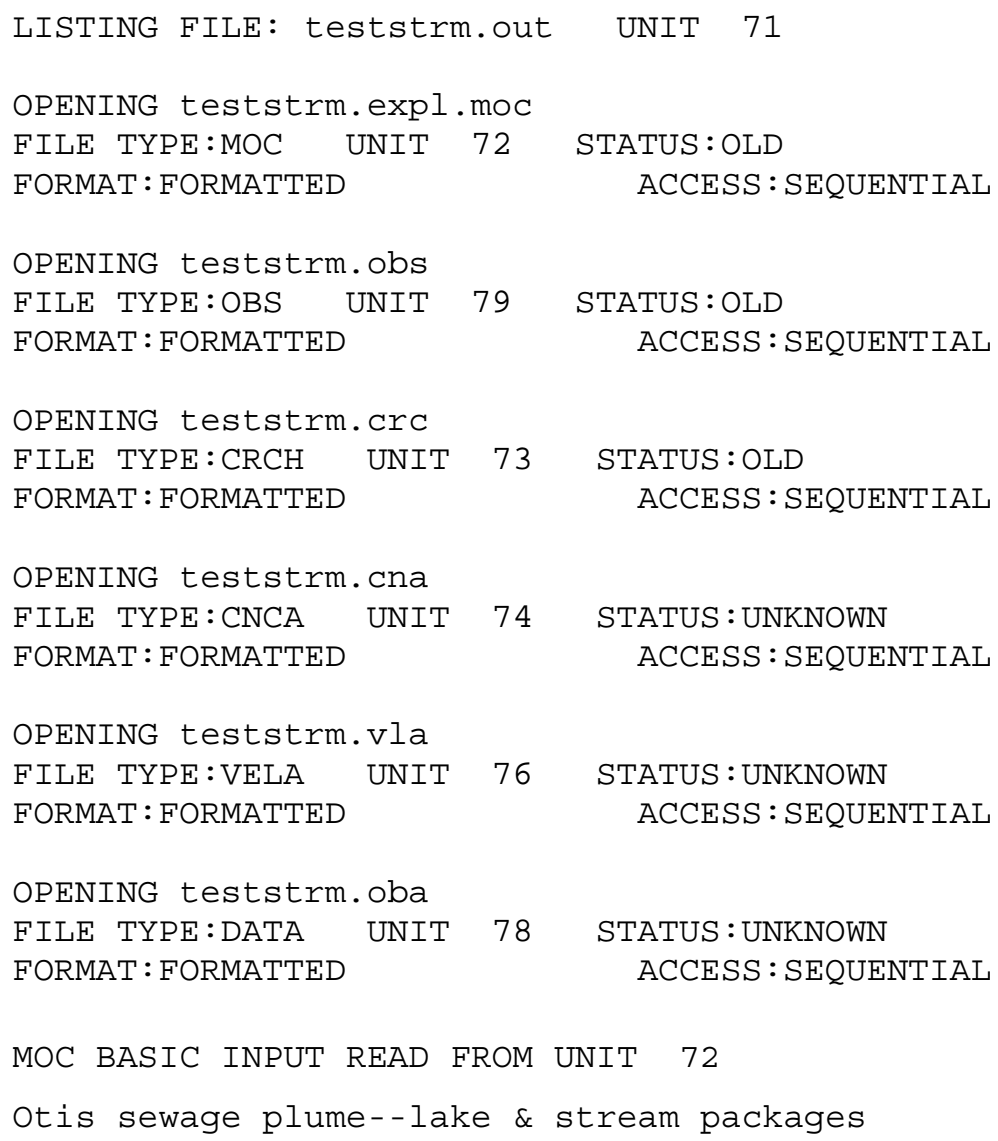


IGENPT ARRAY RELATED TO PARTICLE REGENERATION IN NUMERICAL METHOD:

SINK-SOURCE FLAG FOR LAYER 1
READING ON UNIT 72 WITH FORMAT: (FREE)

\begin{tabular}{|c|c|c|c|c|c|c|c|c|c|c|c|c|c|c|c|c|c|c|c|c|c|c|c|}
\hline & 1 & 2 & 3 & 4 & 5 & 6 & 7 & 8 & 9 & 10 & 11 & 12 & 13 & 14 & 15 & 16 & 17 & 18 & 19 & 20 & 21 & 22 & 23 \\
\hline 1 & 0 & 0 & 0 & 0 & 0 & 0 & 0 & 0 & 0 & 0 & 0 & 0 & 0 & 0 & 0 & 0 & 0 & 0 & 0 & 0 & 0 & 0 & 1 \\
\hline 2 & 0 & 0 & 0 & 0 & 0 & 0 & 0 & 0 & 0 & 0 & 0 & 0 & 0 & 0 & 0 & 0 & 0 & 0 & 0 & 0 & 0 & 1 & 1 \\
\hline 3 & 0 & 0 & 0 & 0 & 0 & 0 & 0 & 0 & 0 & 0 & 0 & 0 & 0 & 0 & 0 & 0 & 0 & 0 & 0 & 0 & 1 & 0 & \\
\hline 4 & 0 & 0 & 0 & 0 & 0 & 1 & 0 & 0 & 1 & 0 & 0 & 0 & 0 & 0 & 0 & 0 & 1 & 0 & 0 & 1 & 0 & 0 & \\
\hline 5 & 0 & 0 & 1 & 0 & 0 & 0 & 0 & 0 & 0 & 0 & 0 & 0 & 0 & 0 & 0 & 0 & 0 & 0 & 0 & 1 & 0 & 0 & \\
\hline 6 & 0 & 0 & 0 & 1 & 1 & 0 & 0 & 0 & 0 & 0 & 0 & 0 & 0 & 1 & 0 & 0 & 0 & 0 & 0 & 0 & 0 & 1 & 1 \\
\hline 7 & 0 & 0 & 0 & 0 & 0 & 0 & 0 & 0 & 0 & 0 & 0 & 0 & 0 & 0 & 0 & 0 & 0 & 0 & 0 & 0 & 0 & 0 & 0 \\
\hline 8 & 0 & 0 & 0 & 0 & 0 & 0 & 0 & 0 & 0 & 0 & 0 & 0 & 0 & 0 & 0 & 0 & 0 & 0 & 0 & 0 & 0 & 0 & 1 \\
\hline 9 & 0 & 0 & 1 & 0 & 0 & 1 & 0 & 1 & 0 & 0 & 1 & 0 & 0 & 1 & 0 & 0 & 0 & 0 & 0 & 0 & 0 & 0 & 0 \\
\hline 10 & 0 & 0 & 0 & 0 & 0 & 0 & 0 & 0 & 0 & 0 & 0 & 0 & 0 & 0 & 0 & 0 & 0 & 0 & 0 & 0 & 0 & 0 & \\
\hline 11 & 0 & 0 & 0 & 0 & 0 & 0 & 0 & 0 & 0 & 0 & 0 & 0 & 0 & 0 & 0 & 0 & 0 & 0 & 0 & 0 & 0 & 0 & \\
\hline 12 & 0 & 0 & 0 & 0 & 0 & 0 & 0 & 0 & 0 & 0 & 0 & 0 & 1 & 1 & 0 & 0 & 0 & 0 & 0 & 0 & 0 & 0 & \\
\hline 13 & 0 & 0 & 0 & 0 & 0 & 0 & 0 & 0 & 0 & 1 & 0 & 1 & 0 & 0 & 0 & 0 & 0 & 0 & 0 & 0 & 0 & 0 & \\
\hline 14 & 0 & 0 & 0 & 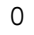 & 0 & 0 & 0 & 0 & 0 & 0 & 0 & 0 & 0 & 0 & 0 & 0 & 0 & 0 & 0 & 0 & 0 & 0 & 1 \\
\hline 15 & 0 & 0 & 0 & 0 & 0 & 0 & 0 & 0 & 1 & 0 & 1 & 0 & 0 & 0 & 0 & 0 & 0 & 0 & 0 & 0 & 0 & 0 & 0 \\
\hline 16 & 0 & 0 & 1 & 0 & 1 & 0 & 1 & 0 & 0 & 0 & 0 & 0 & 0 & 0 & 0 & 0 & 0 & 0 & 0 & 0 & 0 & 0 & 1 \\
\hline 17 & 0 & 0 & 0 & 0 & 0 & 0 & 0 & 1 & 0 & 0 & 0 & 1 & 0 & 0 & 1 & 0 & 1 & 0 & 0 & 0 & 0 & 0 & 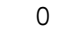 \\
\hline 18 & 0 & 0 & 0 & 0 & 0 & 0 & 0 & 0 & 0 & 0 & 0 & 0 & 0 & 0 & 0 & 0 & 0 & 1 & 0 & 1 & 1 & 1 & 1 \\
\hline 19 & 0 & 0 & 0 & 0 & 0 & 0 & 0 & 0 & 0 & 0 & 1 & 0 & 0 & 0 & 0 & 0 & 0 & 1 & 0 & 0 & 0 & 0 & 0 \\
\hline 20 & 0 & 0 & 0 & 0 & 0 & 0 & 0 & 0 & 0 & 0 & 0 & 1 & 0 & 0 & 0 & 0 & 1 & 0 & 0 & 0 & 0 & 0 & 1 \\
\hline 21 & 0 & 0 & 0 & 0 & 0 & 0 & 0 & 0 & 0 & 0 & 0 & 1 & 0 & 0 & 0 & 1 & 1 & 0 & 0 & 0 & 0 & 0 & 0 \\
\hline 22 & 0 & 0 & 0 & 0 & 0 & 0 & 1 & 0 & 1 & 1 & 1 & 0 & 1 & 0 & 0 & 0 & 1 & 0 & 0 & 0 & 0 & 0 & 0 \\
\hline 23 & 0 & 0 & 0 & 0 & 0 & 0 & 0 & 0 & 0 & 0 & 1 & 1 & 1 & 1 & 1 & 1 & 1 & 1 & 1 & 0 & 0 & 0 & 0 \\
\hline 24 & 0 & 0 & 0 & 0 & 0 & 0 & 0 & 0 & 0 & 0 & 0 & 0 & 1 & 1 & 0 & 1 & 0 & 0 & 1 & 1 & 1 & 1 & 1 \\
\hline 25 & 0 & 0 & 0 & 0 & 0 & 0 & 0 & 0 & 0 & 0 & 0 & 0 & 0 & 1 & 0 & 1 & 0 & 0 & 0 & 0 & 0 & 0 & 0 \\
\hline 26 & 0 & 0 & 0 & 0 & 0 & 0 & 0 & 0 & 0 & 0 & 0 & 0 & 0 & 1 & 0 & 1 & 0 & 0 & 0 & 0 & 0 & 0 & 0 \\
\hline 27 & 0 & 0 & 0 & 0 & 0 & 0 & 0 & 0 & 0 & 0 & 0 & 0 & 0 & 1 & 0 & 1 & 0 & 0 & 0 & 0 & 0 & 0 & 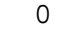 \\
\hline 28 & 0 & 0 & 0 & 0 & 0 & 0 & 0 & 0 & 0 & 0 & 0 & 0 & 0 & 0 & 1 & 0 & 0 & 0 & 0 & 0 & 0 & 0 & 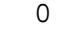 \\
\hline 29 & 1 & 0 & 1 & 0 & 1 & 0 & 1 & 0 & 1 & 0 & 1 & 0 & 1 & 1 & 1 & 1 & 1 & 1 & 0 & 1 & 1 & 0 & 1 \\
\hline 30 & 0 & 0 & 0 & 0 & 0 & 0 & 0 & 0 & 0 & 0 & 0 & 0 & 0 & 0 & 1 & 0 & 0 & 0 & 0 & 0 & 0 & 0 & 0 \\
\hline 31 & 0 & 0 & 0 & 0 & 0 & 0 & 0 & 0 & 0 & 0 & 0 & 0 & 0 & 0 & 1 & 0 & 0 & 0 & 0 & 0 & 0 & 0 & 0 \\
\hline 32 & 0 & 0 & 0 & 0 & 0 & 0 & 0 & 0 & 0 & 0 & 0 & 0 & 0 & 0 & 1 & 0 & 0 & 0 & 0 & 0 & 0 & 0 & 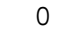 \\
\hline 33 & 0 & 0 & 0 & 0 & 0 & 0 & 0 & 0 & 0 & 0 & 0 & 0 & 0 & 0 & 1 & 0 & 0 & 0 & 0 & 0 & 0 & 0 & 0 \\
\hline 34 & 0 & 0 & 0 & 0 & 0 & 0 & 0 & 0 & 0 & 0 & 0 & 0 & 0 & 0 & 1 & 0 & 0 & 0 & 0 & 0 & 0 & 0 & 0 \\
\hline 35 & 0 & 0 & 0 & 0 & 0 & 0 & 0 & 0 & 0 & 0 & 0 & 0 & 0 & 0 & 1 & 0 & 0 & 0 & 0 & 0 & 0 & 0 & 0 \\
\hline 36 & 0 & 0 & 0 & 0 & 0 & 0 & 0 & 0 & 0 & 0 & 0 & 0 & 0 & 0 & 0 & 0 & 0 & 0 & 0 & 0 & 0 & 0 & 0 \\
\hline
\end{tabular}

$\cdots$

COORDINATES FOR 1 OBSERVATION WELLS:

WELL \# LAYER ROW COLUMN UNIT

$\begin{array}{lllll}1 & 3 & 8 & 14 & 78\end{array}$

OBSERVATION WELL DATA WILL BE WRITTEN ON UNIT NUMBERS LISTED ABOVE CONCENTRATION DATA WILL BE SAVED ON UNIT 74 IN MATRIX FORMAT

DATA FOR EACH STREAM SEGMENT: SOLUTE NO. 1

SEGMENT SOLUTE CONCENTRATION IN :

NUMBER SEGMENT INFLOW OVERLAND FLOW PRECIPITATION

$\begin{array}{cccc}1 & 0.000 E+00 & 0.000 E+00 & 0.000 E+00 \\ 2 & \text { N/A } & 0.000 E+00 & 0.000 E+00 \\ 3 & 0.000 E+00 & 0.000 E+00 & 0.000 E+00 \\ 4 & 0.000 E+00 & 0.000 E+00 & 0.000 E+00\end{array}$




$\begin{array}{ccccc}\text { INITIAL LAKE CONCENTRATIONS: } & \text { LAKE } & \text { CONCENTRATIO } \\ & & & 1 & 0.000 \mathrm{E}+00 \\ & & & 2 & 0.000 \mathrm{E}+00 \\ \text { LAKE } & \text { SOLUTE } & \text { CPPT } & \text { CRNF } & \text { CAUG } \\ 1 & 1 & 0.00 \mathrm{E}+00 & 0.00 \mathrm{E}+00 & \\ 2 & 1 & 0.00 \mathrm{E}+00 & 0.00 \mathrm{E}+00 & \end{array}$

\section{STABILITY AND ACCURACY CRITERIA AND TIME INCREMENT SIZE FOR TRANSPORT:}

STABILITY CRITERIA --- M.O.C.

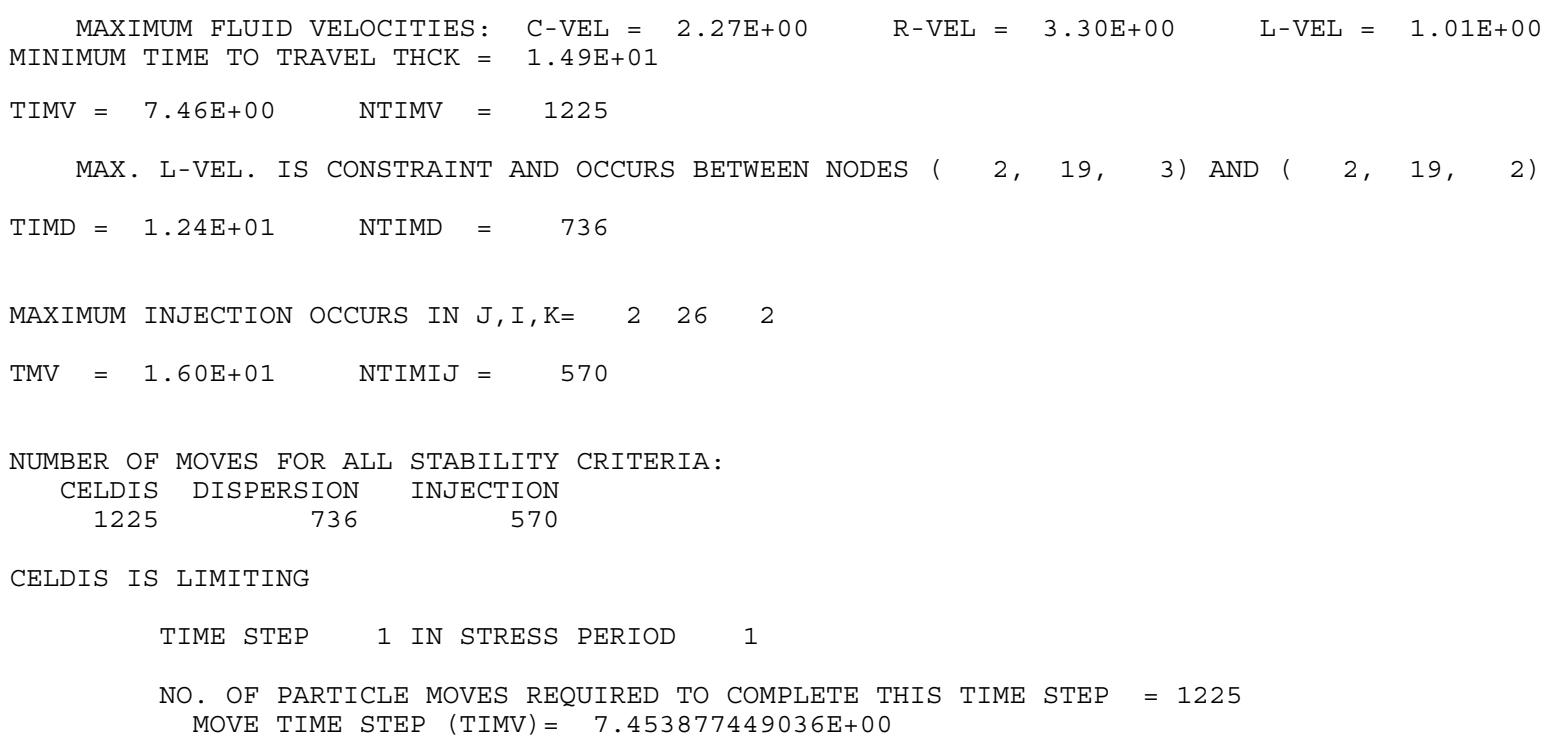

LIMITED INFORMATION PRINTED FOR EACH TRANSPORT TIME INCREMENT:

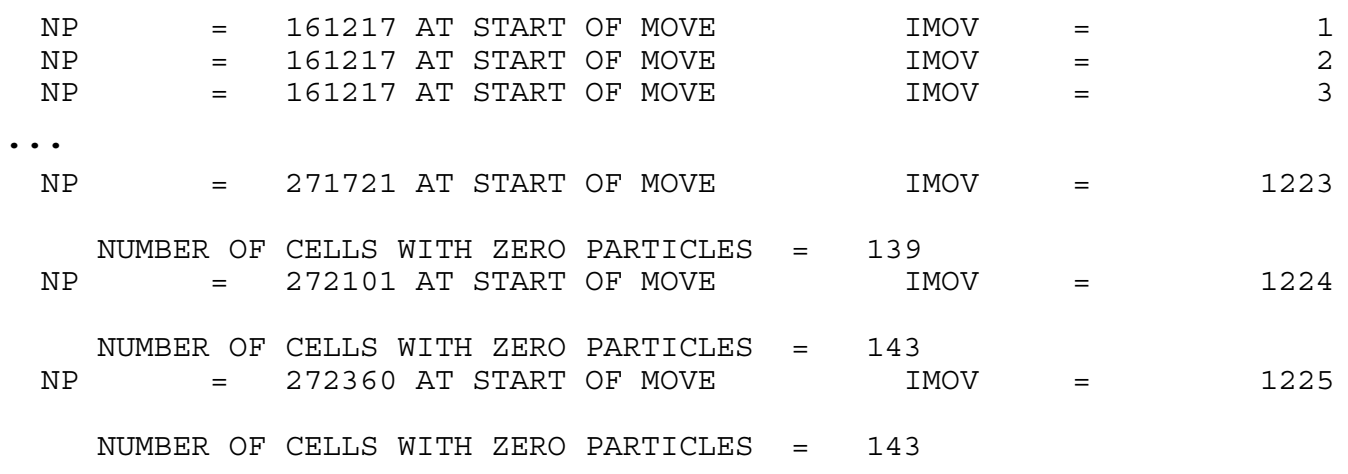

TRANSPORT CALCULATIONS COMPLETED; FINAL CALCULATIONS FOLLOW:

STREAM PACKAGE INFORMATION:

$\begin{array}{ccccccccc}\text { LAYER } & \text { ROW } & \text { COLUMN } & \begin{array}{c}\text { STREAM } \\ \text { NUMBER }\end{array} & \begin{array}{c}\text { REACH } \\ \text { NUMBER }\end{array} & \begin{array}{c}\text { FLOW INTO } \\ \text { STREAM REACH }\end{array} & \begin{array}{l}\text { FLOW OUT OF } \\ \text { STREAM REACH }\end{array} & \begin{array}{l}\text { CONC. OUT OF } \\ \text { STREAM REACH }\end{array} \\ 1 & 1 & 23 & 1 & 1 & 8.640 \mathrm{E}+04 & 7.446 \mathrm{E}+04 & 0.000 \mathrm{E}+00 \\ 1 & 2 & 23 & 1 & 2 & 7.446 \mathrm{E}+04 & 6.644 \mathrm{E}+04 & 0.000 \mathrm{E}+00 \\ 1 & 2 & 22 & 1 & 3 & 6.644 \mathrm{E}+04 & 1.007 \mathrm{E}+05 & 7.479 \mathrm{E}-10\end{array}$




\section{A new Streamflow-Routing (SFR1) Package}

\begin{tabular}{|c|c|c|c|c|c|c|c|}
\hline 1 & 3 & 21 & 1 & 4 & $1.007 E+05$ & $1.355 \mathrm{E}+05$ & 1. $326 \mathrm{E}-07$ \\
\hline & 4 & 20 & 1 & 5 & $1.355 \mathrm{E}+05$ & $1.646 \mathrm{E}+05$ & $9.749 E-06$ \\
\hline & 5 & 20 & 1 & 6 & $1.646 \mathrm{E}+05$ & $1.858 \mathrm{E}+05$ & $5.631 \mathrm{E}-03$ \\
\hline & 17 & 18 & 2 & 1 & $2.679 E+05$ & $2.332 E+05$ & $3.735 E+01$ \\
\hline & 18 & 18 & 2 & 2 & $2.332 E+05$ & $2.139 \mathrm{E}+05$ & $3.735 E+01$ \\
\hline • • & & & & & & & \\
\hline & 27 & 14 & 3 & 12 & $9.508 E+04$ & $9.428 E+04$ & $2.305 E+01$ \\
\hline 1 & 28 & 15 & 3 & 13 & $9.428 E+04$ & $1.081 E+05$ & $2.434 \mathrm{E}+01$ \\
\hline 1 & 29 & 15 & 4 & 1 & $2.260 E+05$ & $2.163 E+05$ & $3.113 E+01$ \\
\hline 1 & 30 & 15 & 4 & 2 & $2.163 E+05$ & $2.114 E+05$ & 3. $113 \mathrm{E}+01$ \\
\hline & 31 & 15 & 4 & 3 & $2.114 E+05$ & $2.076 E+05$ & $3.113 E+01$ \\
\hline 1 & 32 & 15 & 4 & 4 & $2.076 E+05$ & $2.035 E+05$ & $3.113 E+01$ \\
\hline 1 & 33 & 15 & 4 & 5 & $2.035 E+05$ & $1.983 E+05$ & $3.113 E+01$ \\
\hline & 34 & 15 & 4 & 6 & $1.983 E+05$ & $1.924 E+05$ & $3.113 E+01$ \\
\hline 1 & 35 & 15 & 4 & 7 & $1.924 \mathrm{E}+05$ & $1.894 E+05$ & $3.113 E+01$ \\
\hline
\end{tabular}

\begin{tabular}{|c|c|c|c|c|c|c|c|c|c|c|c|}
\hline $\mathrm{E}$ & BUDGETS & $\mathrm{U}$ & & TIME & JT : & & & & & & \\
\hline Lake & Lake & solute & Concen- & Ppt & Stream & Stream & Withdrawal & Runoff & GW & GW & Solute \\
\hline No. & Volume & No. & tration & Mass In & Mass In & Mass Out & Net Mass & Mass In & Mass In & Mass Out & Lake \\
\hline 1 & $1.10 E+08$ & 1 & $3.73 E+01$ & $0.00 \mathrm{E}+00$ & $0.00 \mathrm{E}+00$ & $7.46 \mathrm{E}+07$ & $0.00 \mathrm{E}+00$ & $0.00 \mathrm{E}+00$ & $1.08 \mathrm{E}+08$ & $3.53 E+07$ & $0 E+09$ \\
\hline 2 & $4.72 E+07$ & 1 & $9.35 \mathrm{E}-05$ & $.00 \mathrm{E}+00$ & $0.00 \mathrm{E}+00$ & $0.00 \mathrm{E}+00$ & $0.00 \mathrm{E}+00$ & $0.00 \mathrm{E}+00$ & $1.34 \mathrm{E}+02$ & 1. $01 \mathrm{E}+02$ & $4.38 E+03$ \\
\hline
\end{tabular}

SOLUTE BUDGET AND MASS BALANCE FOR TRANSPORT SUBGRID

VALUES CALCULATED AT END OF :

$\begin{array}{rrrr}\text { STRESS PERIOD } & 1 & \text { OUT OF } & 1 \\ \text { FLOW TIME STEP } & 1 & \text { OUT OF } & 1 \\ \text { TIME INCREMENT } & 1225 & \text { OUT OF } & 1225\end{array}$

TRANSPORT TIME INCREMENT 1225 OUT OF 1225

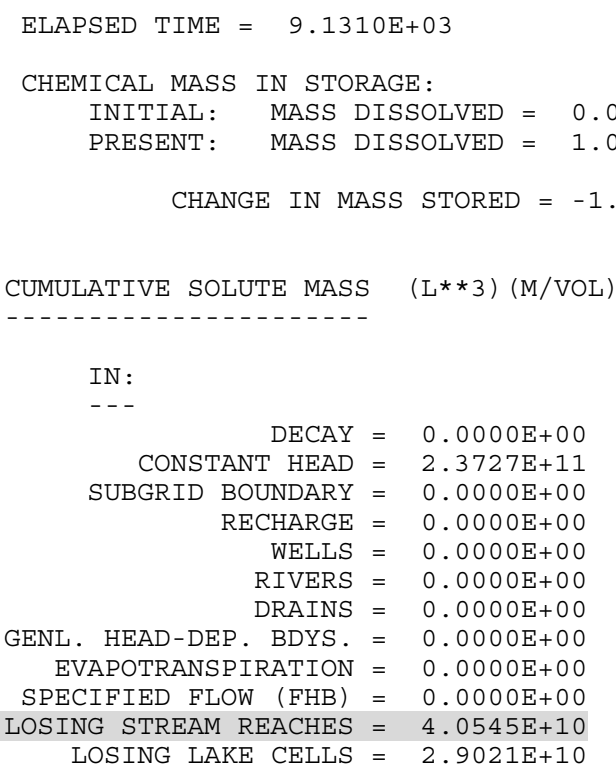

ITEMIZED

BUDGETS

FOR

SOLUTE

FLUXES 
GAINING STREAM RCHS. $=-9.6162 \mathrm{E}+09$

GAINING LAKE CELLS $=-9.4432 \mathrm{E}+10$

TOTAL OUT $=-1.7920 \mathrm{E}+11$

SOURCE-TERM DECAY $=0.0000 E+00$

RESIDUAL $=2.0905 \mathrm{E}+10$

PERCENT DISCREPANCY $=6.8129 \mathrm{E}+00$ RELATIVE TO MASS FLUX IN

Following (enclosed in a border) are the abridged contents of the Gaging Station 4 output file for test simulation 2. The concentration data included in this output file are also plotted in fig. 16.

File name: teststrm.sg2

\begin{tabular}{|c|c|c|c|c|c|c|c|}
\hline & No. & , I, J Coord. & 1,28 , & STREAM & EGMENT = & $\mathrm{REACH}=$ & $12 "$ \\
\hline "DATA & Time & Stage & Flow & Depth & Width & M-P Flow & Concentration" \\
\hline & $7.454 \mathrm{E}+00$ & $3.474 \mathrm{E}+01$ & 1.179E+05 & 3. $016 \mathrm{E}-01$ & $5.000 \mathrm{E}+00$ & 1. $430 \mathrm{E}+05$ & $0.000 \mathrm{E}+00$ \\
\hline & 1. $491 \mathrm{E}+01$ & $3.474 E+01$ & $1.179 E+05$ & 3. $016 \mathrm{E}-01$ & $5.000 \mathrm{E}+00$ & 1. $430 \mathrm{E}+05$ & $0.000 \mathrm{E}+00$ \\
\hline & $2.236 E+01$ & $3.474 \mathrm{E}+01$ & $1.179 E+05$ & $3.016 \mathrm{E}-01$ & $5.000 \mathrm{E}+00$ & 1. $430 \mathrm{E}+05$ & $0.000 \mathrm{E}+00$ \\
\hline & $2.982 E+01$ & $3.474 E+01$ & $1.179 \mathrm{E}+05$ & $3.016 \mathrm{E}-01$ & $5.000 E+00$ & 1. $430 \mathrm{E}+05$ & $0.000 E+00$ \\
\hline & $3.727 E+01$ & $3.474 \mathrm{E}+01$ & $1.179 E+05$ & $3.016 E-01$ & $5.000 \mathrm{E}+00$ & $1.430 \mathrm{E}+05$ & $0.000 \mathrm{E}+00$ \\
\hline & 4. $472 \mathrm{E}+01$ & $3.474 E+01$ & 1.179E+05 & 3. $016 E-01$ & $5.000 \mathrm{E}+00$ & $1.430 \mathrm{E}+05$ & $0.000 \mathrm{E}+00$ \\
\hline & 5. $218 E+01$ & $3.474 E+01$ & 1.179E+05 & $3.016 \mathrm{E}-01$ & $5.000 E+00$ & 1. $430 \mathrm{E}+05$ & $3.775 \mathrm{E}-17$ \\
\hline & $5.963 E+01$ & $3.474 E+01$ & $1.179 E+05$ & 3. $016 \mathrm{E}-01$ & $5.000 \mathrm{E}+00$ & 1. $430 \mathrm{E}+05$ & $3.978 E-16$ \\
\hline & & & & & & & \\
\hline & $9.079 E+03$ & $3.474 E+01$ & 1.179E+05 & $3.016 E-01$ & $5.000 E+00$ & $1.430 \mathrm{E}+05$ & $3.740 \mathrm{E}+01$ \\
\hline & $9.086 \mathrm{E}+03$ & $3.474 \mathrm{E}+01$ & 1.179E+05 & 3. $016 E-01$ & $5.000 \mathrm{E}+00$ & $1.430 E+05$ & $3.739 E+01$ \\
\hline & $9.094 \mathrm{E}+03$ & $3.474 \mathrm{E}+01$ & $1.179 \mathrm{E}+05$ & $3.016 \mathrm{E}-01$ & $5.000 \mathrm{E}+00$ & $1.430 \mathrm{E}+05$ & $3.739 \mathrm{E}+01$ \\
\hline & $9.101 E+03$ & $3.474 E+01$ & $1.179 \mathrm{E}+05$ & 3. $016 \mathrm{E}-01$ & $5.000 E+00$ & $1.430 \mathrm{E}+05$ & $3.738 E+01$ \\
\hline & $9.109 \mathrm{E}+03$ & $3.474 \mathrm{E}+01$ & $1.179 \mathrm{E}+05$ & 3.016E-01 & $5.000 \mathrm{E}+00$ & $1.430 \mathrm{E}+05$ & $3.736 \mathrm{E}+01$ \\
\hline & $9.116 \mathrm{E}+03$ & $3.474 E+01$ & $1.179 \mathrm{E}+05$ & $3.016 \mathrm{E}-01$ & $5.000 E+00$ & $1.430 \mathrm{E}+05$ & $3.737 \mathrm{E}+01$ \\
\hline & $9.124 \mathrm{E}+03$ & $3.474 \mathrm{E}+01$ & $1.179 \mathrm{E}+05$ & $3.016 \mathrm{E}-01$ & $5.000 \mathrm{E}+00$ & $1.430 \mathrm{E}+05$ & $3.737 \mathrm{E}+01$ \\
\hline & $9.131 E+03$ & $3.474 E+01$ & 1.179E+05 & 3. $016 E-01$ & $5.000 E+00$ & 1. $430 \mathrm{E}+05$ & $3.735 E+01$ \\
\hline
\end{tabular}


Since 1879, the U.S. Geological Survey has been providing maps, reports, and information to help others who manage, develop, and protect our Nation's water, energy, mineral, land, and biological resources. We help find natural resources, and we supply scientific understanding needed to help minimize or mitigate the effects of natural hazards and the environmental damage caused by human activities. The results of our efforts touch the daily lives of almost everyone. 